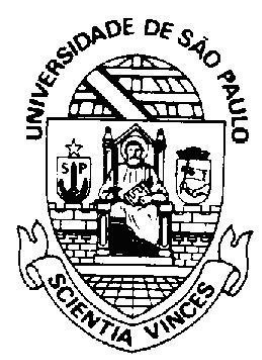

UNIVERSIDADE DE SÃo PAULO

FACULDADE DE FILOSOFIA, LETRAS E CIÊNCIAS HuMANAS

DEPARTAMENTO DE HISTÓRIA

Programa de Pós-GRAdUAÇ̃̃o EM HistóRIA SOCIAL

DisSERTAÇÃo DE MESTRADO

Pedro Gustavo Aubert

ENTRE AS IdÉIAS E A AÇÃO: O VISCONDE de URUGUAI, O

Direito e a Política na Consolidação do Estado

NACIONAL (1850-1866)

SÃo PAUlO

2011 


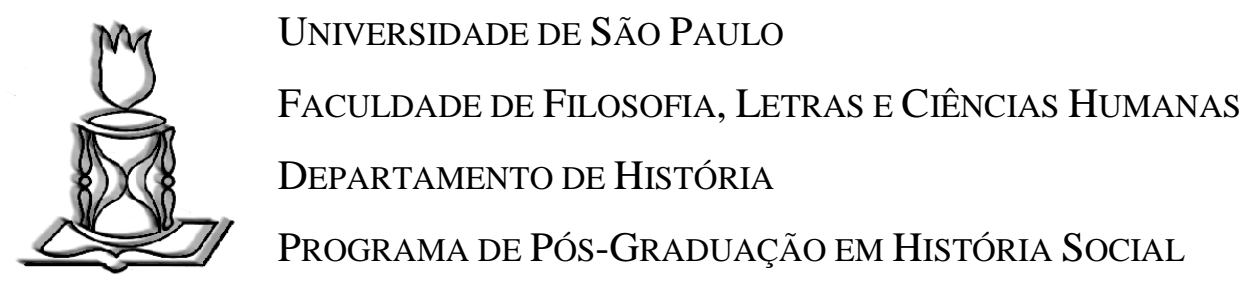

Pedro Gustavo Aubert

\section{ENTRE AS IDÉIAS E A AÇÃo: O VISCONDE dE URUGUAI, O Direito e a Política na Consolidação do Estado NACIONAL (1850-1866)}

Dissertação apresentada ao Programa de PósGraduação em História Social da Faculdade de Filosofia, Letras e Ciências Humanas da Universidade de São Paulo, para a obtenção do título de Mestre em História.

Orientadora: Profa. Dra. Monica Duarte Dantas.

EXEMPLAR ORIGINAL

SÃo PAULO 


\title{
RESUMO:
}

Paulino José Soares de Souza (1807-1866) foi um dos políticos mais importantes do Partido Conservador no Império. Foi agraciado com o titulo de Visconde do Uruguai em 1855, depois de ter passado pelos Ministérios da Justiça e dos Negócios Estrangeiros em períodos extremamente importantes para a história do Império como a aprovação das reformas do Regresso, o fim do tráfico negreiro intercontinental e as campanhas platinas contra Rosas e Oribe. Subindo o Ministério da Conciliação em 1853, nunca mais voltou a responder por nenhuma pasta ministerial até a sua morte, permanecendo porém ativo como senador e conselheiro de Estado. O período compreendido entre 1853 e sua morte em 1866 é considerado por grande parte da historiografia como um período de ostracismo de Uruguai, idéia essa que começou a ser gestada pelos seus biógrafos do século XIX. Contudo foi nesse período que Uruguai escreveu suas obras. O presente trabalho visa não somente contestar essa idéia, mas expor como nesse período Uruguai deixou antever elementos de um projeto de organização do Estado Nacional.

Palavras-Chave: Projeto, Império do Brasil, Direito, Política, Partidos, Conciliação.

\begin{abstract}
:
Paulino José Soares de Souza (1807-1866) was one of the most influential members of the Conservative Party during the Brazilian Empire. He was awarded the title of Viscount Uruguay in 1855, after having served as Minister of Justice and as Minister of Foreign Affairs during extremely important periods for the history of the Empire, involving the reforms implemented by the movement which ultimately led to the organization of the Conservative Party (known as Regresso). After the Conciliation Cabinet took office in 1853, he never again held a ministerial office, but remained active as a Senator and member of the Council of State. The period extending from 1853 up to his death in 1866 is generally considered as a period of ostracism, a notion which was initially suggested by his $19^{\text {th }}$ century biographers. But this was the period during which Viscount Uruguay wrote his major works. This investigation aims not only at disputing the idea of a retirement, but to show that during this period he drafted a project for the organization of the National State.
\end{abstract}

Keywords: Project, Brazilian Empire, Right, Policy, Parties, Conciliation.

E-mail do autor: pedroaubert@yahoo.com.br 


\section{AgRADECIMENTOS}

Ao longo do percurso que culminou nessa dissertação, pude passar por uma experiência ímpar de aprendizagem, na qual pude contar com auxílios das mais diversas naturezas.

Gostaria de agradecer ao apoio financeiro da Fundação de Amparo à Pesquisa do Estado de São Paulo (FAPESP), que permitiu dedicação integral ao mestrado no período em que recebi a bolsa, sem a qual não poderia ter realizado a pesquisa documental no Rio de Janeiro. Agradeço ao Programa de Pós-Graduação em História Social da USP, em especial ao apoio dos funcionários da Pós-Graduação do Departamento de História.

Agradeço muito especialmente à Monica Dantas por todo o apoio e orientação ao longo desses anos de mestrado. Sem sua leitura cuidadosa e atenta, dificilmente esta dissertação teria tomado corpo. Além disso, também agradeço o incentivo que deu no momento final de redação do trabalho.

Agradeço ao Serviço de Biblioteca e Documentação da Faculdade de Direito da USP, especialmente aos funcionários Agostinha Cardoso Batista e Jair Balduíno Ferreira, pelo auxílio quando iniciei a pesquisa das fontes da Seção de Justiça do Conselho de Estado. Aproveito o ensejo também para agradecer a André Javier Payar pela indicação das fontes, não somente na Biblioteca, mas também sobre o material da Seção de Justiça constante no Arquivo Nacional.

Agradeço ao Instituto Histórico e Geográfico Brasileiro no Rio de Janeiro na pessoa de Pedro Tórtima, grande exemplo de zelo para com os pesquisadores. Agradeço aos funcionários do Arquivo Nacional pelo auxílio na pesquisa. Agradeço também à Biblioteca Nacional, onde pude encontrar importante documentação.

Agradeço à equipe do Hotel São Jorge no Rio de Janeiro: ao seu Pinheiro, a Rosa e ao Francisco.

Agradeço ao professor Leandro Piquet Carneiro do Departamento de Ciência Política da USP pelo incentivo que me deu para ingressar no mestrado.

Agradeço aos professores cujas disciplinas cursei na Pós-Graduação: Sara Albieri, José Reinaldo de Lima Lopes e Maria Helena P.T. Machado. A discussão 
desenvolvida nessas disciplinas, cada uma ao seu modo, foi de fundamental importância para o desenvolvimento do trabalho.

Agradeço aos professores Rafael de Bivar Marquese e Cecília Helena de Salles Oliveira pela participação no exame de qualificação, cujas críticas foram de grande proveito para a dissertação. Agradeço especialmente por me dissuadirem da idéia de fazer um mestrado de sete capítulos, pretensão essa praticamente inexeqüível dentro dos prazos institucionais.

Agradeço ao professor István Jancsó (in memorian) por ter incentivado e acompanhado a leitura (por duas vezes) dos sete volumes da História do Brasil de Pedro Calmon e por ter me apresentado para a Monica

Agradeço ao finado professor Ladislao Szabo da Universidade Presbiteriana Mackenzie pela oportunidade que me deu ainda na minha graduação de participar do livro Hungria 1956, juntamente com os professores Angelo Segrillo e Maria Aparecida de Aquino do Departamento de História da USP.

Agradeço ao Grupo de Estudos Império Expandido: Alain El Youssef, André Nicácio Lima “Godinho”, Bruno Fabris Estefanes, Tâmis Parron e Vivian Costa. Sem dúvida, nossas discussões tiveram um peso cavalar no desenvolvimento dessa dissertação. Além das discussões, agradeço a esse grupo os diversos momentos de descontração em bares e congêneres.

Agradeço aos amigos que passaram pela equipe do Acervo Histórico da Discoteca Oneyda Alvarenga do Centro Cultural São Paulo, e aos que lá permanecem: Aurélio Eduardo Nascimento, Ana Maria Campanhã, Carlos Gimenes, Carlos Eduardo Sampietri, Eduardo Cotarelli, Fábio Alex, Felipe Guarnieri "Dindinho", Lucas Lara, Luiza Fioravanti, Maricler Martinez, Rafael Vitor Barbosa Souza, Vera Cardim e Wilma Oliveira. Ainda no Centro Cultural São Paulo, gostaria de agradecer à Carla Rabelo, Gisela Del Puerto, Juliano Gentile e Maurício Faria Ramos. Mais do que colegas de trabalho, pude encontrar verdadeiros amigos durante minha passagem por essa instituição.

Agradeço à Lúcia Elena Thomé do Instituto de Estudos Brasileiros da USP, à Mariana Pedroso de Moraes, à Valquíria Maroti Carozze e ao Pedro Machado "Chalaça" pelo apoio. 
Agradeço à Flávia Maria "Chita" por ter colocado o Visconde do Uruguai na minha vida, quando nos idos de maio de 2005 me presenteou com o volume Visconde do Uruguai da Coleção Formadores do Brasil da Editora 34. Agradeço também à Ana Maria Anunciato e Caroline Serafim pela amizade e pelos cafés.

Agradeço ao Alex Fugiwara e ao Bruno Redondo por nossas longas madrugadas de estudos no Instituto de Matemática e Estatística da USP.

Agradeço às amigas Cecília e Silvina Bianchini, Thaís da Cunha Gomes e Verônica Kienen Dias pelos anos de amizade e apoio.

Agradeço também à amizade e momentos de descontração proporcionados por Aline Frischlander, André Mangini, Mariana Vannucchi e Mileine Cavaletti.

Agradeço ao Rogério Vilela e ao Charles Medeiros pela nossa amizade e pelas diversas cervejas em Águas da Prata.

Agradeço ao Bruno Tasca pelos 23 anos de amizade.

Agradeço também a amizade e o apoio das pessoas com as quais convivo cotidianamente: João Cassiano da Silva "Careca", João Paulo Silva, Letícia Silva, Maria do Carmo Freitas Silva "Alzira", Giovana Silva, Rita, Marcos "Barão", Laís, Joaquim Jesus Rocha “Joca", e Vera Cruz Pereira da Rocha "Vanda".

Agradeço à minha família pelas diversas e incontáveis formas de apoio ao longo desse percurso, em especial à minha tia Djanira de Campos e aos meus pais Maria Beatriz dos Santos Aubert e Francis Henrik Aubert. Agradeço ao meu irmão Eduardo Henrik Aubert pelas diversas conversas sobre biografia e história e madrugadas de estudo ao redor da velha mesa de jantar.

Por fim, agradeço à Eliane Pinheiro pela compreensão das minhas ausências e pelo companheirismo nos momentos mais críticos do desenvolvimento do trabalho. Seu apoio incondicional foi fundamental em todas as etapas. 


\section{SUMÁRIO DA DISSERTAÇÃO}

Introdução

Capítulo 1: O Poder Moderador e a Interferência do Monarca no Poder

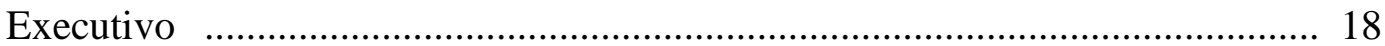

1.1 - A política da Conciliação e a Interferência do Monarca .................... 20

1.2 - O Rei Reina e Governa ........................................................... 32

Capítulo 2: Razão de Estado, Direitos e Interesses .......................................... 58

2.1 - O Contencioso Administrativo e seu Funcionamento no

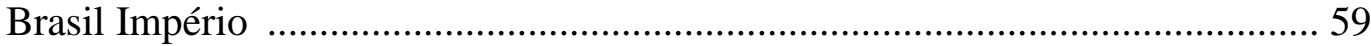

2.2 - A Proposta de Uruguai Para a Organização

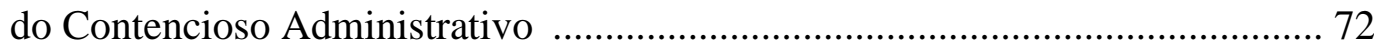

2.3 - O Visconde do Uruguai e o Debate Sobre o

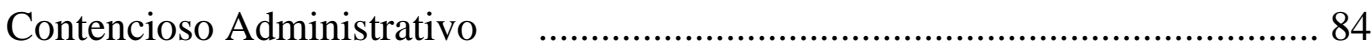

Capítulo 3: Pelo Império, Contra a Província ...................................................... 100

3.1 - A Definição do Espaço das Assembléias ............................................. 101

3.2 - As Obras de Direito e o Debate sobre a Centralização ........................ 115

Capítulo 4: Contrabando, Propriedade e Direitos: o Problema da Escravidão ... 133

4.1 - Direito e Escravidão ................................................................................. 139

4.2 - O Ministro e o Tráfico Ilegal ............................................................... 145

4.3 - O Conselheiro de Estado Diante da Escravidão ................................. 154

Considerações Finais .................................................................................172

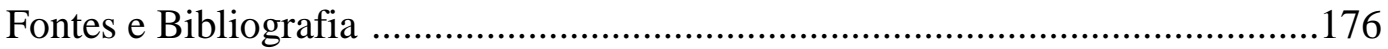




\section{INTRODUÇÃO}

Referências a Paulino José Soares de Souza, Visconde do Uruguai são inevitáveis nas obras que se dedicam a estudar a política imperial do $2^{\circ}$ Reinado. Tanto trabalhos acadêmicos quanto biografias encomiásticas reconhecem sua importância na política oitocentista. Contudo, a grande maioria destas obras destaca sua atuação no período em que ocupou o Ministério da Justiça (1840-1844), estando à frente da aprovação de parte das reformas do chamado Regresso Conservador na década de 1840. Quando não se debruçam sobre este período, a atenção se volta à sua atuação como ministro dos Negócios Estrangeiros nos inícios da década de 1850. Paralelamente, seus livros, escritos na década de 1860, são normalmente tomados como fonte para o estudo de sua atuação em períodos anteriores.

Paulino José Soares de Souza nasceu em Paris, em 1807. Sua família mudou-se para Portugal em 1814, transferindo-se para São Luís do Maranhão quatro anos depois. Em 1823, foi estudar direito em Coimbra, onde fez amizade com Honório Hermeto Carneiro Leão, futuro Marquês do Paraná. Em 1828, devido à revolta do Porto, retornou ao Brasil, retomando seus estudos dois anos depois na Faculdade de Direito de São Paulo, onde era ligado ao grupo do Professor Júlio Frank, de inspirações liberais e republicanas. Ali, mesmo antes de se formar, sustentava-se com a advocacia. Em 1832, seu amigo Honório Hermeto o convidou para ocupar um cargo de juiz na Corte ${ }^{1}$.

Em 1833, Paulino se casou com Ana Maria Macedo Álvares de Azevedo. Esse casamento uniu Paulino a Rodrigues Torres, já ministro da Marinha, e casado com a irmã de Ana Maria. As irmãs pertenciam a uma rica família de proprietários. Em 1835, Evaristo da Veiga o lançou candidato na chapa dos moderados para a Assembléia Provincial do Rio de Janeiro. No ano seguinte, Feijó o nomeou para a presidência da Província do Rio de Janeiro no lugar de Rodrigues Torres. Em 1837, acumulou o cargo de deputado geral pelo Rio de Janeiro, tornando-se membro da Comissão das Assembléias Provinciais da referida casa, na qual foi elaborado o parecer sobre a

\footnotetext{
${ }^{1}$ SOUZA, J. A. Soares de. A vida do Visconde de Uruguai (1807-1866). São Paulo: Companhia Editora Nacional, 1944.
} 
Interpretação do Ato Adicional ${ }^{2}$. Como passou à oposição, foi demitido por Feijó, retornando, porém, pouco depois à presidência da mesma província com a subida de Araújo Lima à Regência, permanecendo no posto até 1840. Assumiu então a função de ministro da Justiça, em 1840, no lugar de José Antonio da Silva Maia, no gabinete de 18 de maio daquele ano. Neste Ministério, destacou-se na aprovação da Lei de Interpretação do Ato Adicional de 1834. Com a subida do gabinete maiorista, saiu do Ministério. Todavia, quando este caiu, retornou ao ministério com o gabinete de 23 de março de $1841^{3}$. Neste período, como ministro da Justiça, merecem destaque a aprovação da Lei do Conselho de Estado e a Reforma do Código de Processo Criminal (Lei de 3 de dezembro de 1841 e respectivos regulamentos, dos quais foi autor). Substituído este gabinete em 23 de janeiro de 1843, assumiu a Pasta dos Negócios Estrangeiros em 8 de junho do mesmo ano e, interinamente, a da Justiça em 30 de dezembro. Com a subida do gabinete de 2 de fevereiro de 1844, deixou o Ministério, retornando somente em 1849 como ministro dos Negócios Estrangeiros, função que exerceu até a subida do chamado Gabinete na Conciliação em 6 de setembro de $1853^{4}$.

Paulino Soares de Souza saiu do gabinete em 1853 e nunca mais voltou a responder por uma pasta ministerial. Em 1854, foi agraciado com o título de Visconde do Uruguai. No ano seguinte, foi nomeado enviado extraordinário e ministro plenipotenciário junto a Napoleão III para a negociação de um tratado de limites com a Guiana Francesa. Viajou a Paris no mesmo ano, voltando apenas no final de 1856. Essa viagem permitiu-lhe ver instituições liberais estrangeiras em pleno funcionamento, o que, nas palavras do próprio Visconde, provocou-lhe uma verdadeira "revolução nas idéias". Nos anos seguintes, recusou, por duas vezes, o convite para assumir a presidência do Conselho de Ministros, em 1857 e 1859. Alguns anos depois, em 1862, publicou o Ensaio Sobre o Direito Administrativo e, em 1865, seus Estudos Práticos

\footnotetext{
${ }^{2}$ Parecer da Comissão das Assembléias Provinciais da Câmara dos Deputados de 10 de julho de 1837, sobre a interpretação do Ato Adicional in: CARVALHO, J.M. (ORG), Visconde do Uruguai. São Paulo, Editora 34, 2002. p. 524-534.

3 JAVARI, Barão. Organizações e Programas Ministeriais. Regime Parlamentar no Império. Rio de Janeiro, Arquivo Nacional, 1962.

${ }^{4}$ : SOUZA, J. A. Soares de. A vida do Visconde de Uruguai (1807-1866). São Paulo: Companhia Editora Nacional, 1944. JAVARI, Barão, op.cit.. MATTOS, I.R. O Tempo Saquarema. Editora Hucitec, São Paulo, 1987; ESTEFANES, B.F. Conciliar o Império: Honório Hermeto Carneiro Leão e a consolidação do Estado brasileiro. São Paulo, FAPESP, Relatório Parcial de Mestrado.
} 
Sobre a Administração das Províncias no Brasil. As duas obras, como depois veremos, tiveram origem no trabalho encomendado pelo Visconde de Olinda, em 1857, para a Comissão das Assembléias Provinciais do Senado a respeito das administrações provinciais. O parecer encomendado nessa ocasião foi redigido pelo Visconde do Uruguai, sendo publicado como anexo ao Relatório do Ministério do Império de 1858, ocupado então por Olinda. Este trabalho recebeu o título: Bases Para Melhor Organização das Administrações Provinciais. Em 1866, morria o Visconde do Uruguai aos 59 anos.

Além de pouco estudada, a fase compreendida entre a saída do ministério e sua morte é considerada por alguns autores como um período de ostracismo político de Uruguai. Esta visão começou a ser construída pelo próprio Uruguai, que, em correspondências com amigos e em sua autobiografia ${ }^{5}$, fazia questão de afirmar que havia se retirado da política. Joaquim Manuel de Macedo, ao escrever seu necrológio, corroborou esta visão, presente em biografias posteriores e mantida no livro de seu bisneto, A Vida do Visconde do Uruguai, de $1944^{6}$.

A primeira vez em que Uruguai falou explicitamente que se retirava da política foi em uma carta de 1859 dirigida a José Antonio Saraiva. Uruguai, naquela ocasião, dizia que se afastara da política e que estava "muito tranqüilo e satisfeito com a resolução que tomei de concentrar-me na sociedade de minha família, de poucos amigos e de meus livros." ${ }^{, 7}$ Em sua autobiografia, escrita em terceira pessoa, Uruguai manteve o mesmo discurso da referida missiva:

Tem o Visconde do Uruguai sido nomeado pelo Governo Imperial membro de várias Comissões importantes e encarregado como Plenipotenciário, de várias negociações diplomáticas no Rio de Janeiro. Depois da volta da Europa em 1856, retirou-se o Visconde do Uruguai da arena dos Partidos, limitando-se ao cumprimento de seus deveres como Senador e Conselheiro de Estado, aos seus estudos de gabinete e à

\footnotetext{
${ }^{5}$ Autobiografia do Visconde do Uruguai. 12p. Biblioteca Nacional, Coleção Tobias Monteiro, Documento: 63,04,001 n⿳⺈ 47

${ }^{6}$ SOUZA, J. A. Soares de. A vida ... op.cit. MACEDO, J.M. Revista do Instituto Histórico e Geográfico Brasileiro. TOMO 29, VOLUME 33, 1866 P.P. 471-78 Rio de Janeiro, Garner. Macedo também biografou o Visconde do Uruguai no Ano Biográfico Brasileiro. VER: MACEDO, J.M. Ano Biográfico Brasileiro. Rio de Janeiro, Tipografia e Litografia do Imperial Instituto Artístivo, v.3; SISSON, S.A. Biografia do Visconde do Uruguai. Impresso. Galeria dos Brasileiros Ilustres. IHGB: Arm.1 Gav.1 nº55; SOUSA, A.P.S. Três Brasileiros ilustres: José Antonio Soares de Sousa, Visconde do Uruguai e Cons. Paulino José Soares de Sousa. Contribuições biográficas de Álvaro Paulino Soares de Sousa por ocasião do centenário da iindependência. 1922. IHGB: Lata 497 Doc.2. Texto Datilografado.

${ }^{7}$ Carta de Uruguai a Saraiva de 12 de dezembro de 1859. IHGB: Lata 270, documento 44.
} 
educação de seus últimos filhos. No ano de 1862 publicou o Visconde do Uruguai em dois volumes, impressos na Typographia Nacional, o seu Ensaio Sobre o Direito Administrativo, com referência ao estado e instituições peculiares do Brasil, obra que parece o prelúdio de doutrina mais positiva, mais prática e vasta para a qual tem reunido volumosos materiais. ${ }^{8}$

Sua biografia na Galeria dos Brasileiros Ilustres, assim como as demais que surgiram sobre ele no século XIX mantiveram o mesmo discurso de retirada da política. "De volta dessa missão o Sr. Visconde de Uruguai não tem mais tomado parte ativa nos negócios do país, limitando-se a tratar deles como senador do Império"`. Na década de 1920, quando da comemoração do centenário da independência, Álvaro Paulino Soares de Souza, descendente de Uruguai, escreveu biografias de seus antepassados, entre eles Uruguai. Ali, mantém-se a mesma visão de retirada da política: "Estava terminada a sua carreira política, dedicando-se daí em diante ao preparo das obras sobre Direito, que publicou e ainda hoje são apreciadas, e seus deveres de senador e conselheiro de Estado" ". José Antônio Soares de Souza, em A Vida do Visconde do Uruguai, reafirma a idéia ainda pouco contestada de que seu bisavô se retirara da política. A despeito de ser um trabalho rico em informações, no qual o autor pôde se valer de um vasto arquivo familiar, trata-se, como a maior parte das biografias produzidas sobre Uruguai, de uma

\footnotetext{
8 Autobiografia do Visconde do Uruguai. 12p. Biblioteca Nacional, Coleção Tobias Monteiro, Documento: 63,04,001 $\mathrm{n}^{\circ}$ 47. As negociações que Uruguai cita neste trecho foram realizadas em $1857 \mathrm{e}$ 1858. Os documentos referentes a ela compõe a maior parte da Coleção Tobias Monteiro na Biblioteca Nacional. Havia diversas pendências referentes aos tratados de outubro de 1851 firmados com a República Oriental do Uruguai e com a Confederação Argentina, que foram instituídos por Paulino de Souza quando fora ministro. Ver: IHGB: Carta de Poder geral e especial pela qual VMI há por bem nomear seu plenipotenciário ao Visconde do Uruguai para negociar com os plenipotenciários da Confederação Argentina e da República Oriental do Uruguai um tratado definitivo de aliança e regular seus respectivos direitos e obrigações; 15/10/1858. Arm. 1 Gav.1 nº 69; IHGB: Carta de poder geral pala qual VMI há pó bem nomear seu plenipotenciário ao Visconde do Uruguai para que possa tratar da revisão do tratado de comércio e navegação existente Entre o Império do Brasil e a República Oriental do Uruguai. 30/05/1857. Arm.1 Gav.1 Doc nº 67. FERREIRA, G.N. O Rio da Prata e a Consolidação do Estado Imperial. São Paulo, Editora Hucitec, 2006.

${ }^{9}$ SISSON, S.A. Biografia do Visconde do Uruguai. Impresso. Galeria dos Brasileiros Ilustres. IHGB: Arm. 1 Gav. 1 n55.

10 ÁLVARO PAULINO SOARES DE SOUSA, Três Brasileiros ilustres: José Antonio Soares de Sousa, Visconde do Uruguai e Cons. Paulino José Soares de Sousa. Contribuições biográficas de Álvaro Paulino Soares de Sousa por ocasião do centenário da independência. 1922. IHGB: Lata 497 Doc.2. Texto Datilografado.
} 
obra cujo teor é o enaltecimento do Visconde, a defesa de suas posições políticas, destacando suas qualidades pessoais ${ }^{11}$.

Esta visão sobre a atuação de Uruguai, construída desde o século XIX, aparece pouco contestada na historiografia e, em certa medida, é mantida por autores como Ilmar Rohloff de Mattos, José Murilo de Carvalho e Miriam Dohlnikoff. Em seus trabalhos, a despeito das divergências de interpretação da política no Brasil imperial, fazem referências ao Visconde, embora ele não fosse diretamente o foco de suas reflexões. Porém, mais do que isso, utilizam-se do Ensaio de Uruguai para tratarem basicamente de questões políticas relativas às décadas de 1830 e 1840, referindo-se pouco ao período de produção da dita obra. ${ }^{12}$. Tal prática, aliada à ausência de estudos centrados nos últimos anos de vida de Uruguai tendem a colaborar com a permanência de visões sedimentadas acerca da suposta inação política, do Visconde nesse período..

José Murilo de Carvalho ${ }^{13}$ e Richard Graham ${ }^{14}$ usam como argumento para reforçar seu suposto afastamento da política o fato de ele ter-se posicionado contrariamente à política de conciliação ${ }^{15}$, o que o teria feito optar por não mais aceitar ministérios daí em diante, entendendo-se, desse modo, sua ausência de gabinetes como ausência política tout court.

Contudo, o afastamento de Uruguai da "luta política" com a ascensão do gabinete da conciliação deve ser examinado com bastante cautela. Em 1860, por exemplo, Uruguai envolveu-se em uma polêmica a respeito do Poder Moderador com Zacarias de Góes e Vasconcelos. Conforme será discutido no Capítulo 1, essa polêmica originou-se em 1857 com a publicação da obra de José Antonio Pimenta Bueno (futuro

\footnotetext{
${ }^{11}$ Importante leitura crítica desta obra nos é dada por Ilmar Rohloff de Mattos. Este considera o trabalho de José Antônio nitidamente inspirado no trabalho de Nabuco, e que ao pretender fazer da figura de Paulino de Souza o estadista do sul correspondente àquele do nordeste, acaba por esconder sua significação real, tal o anseio de exaltação. MATTOS, I.R. O Tempo Saquarema, op.cit. p.155-156.

${ }^{12}$ MATTOS, I.R. O Tempo Saquarema. Editora Hucitec, São Paulo, 1987; CARVALHO, J.M. A Construção da Ordem, Civilização Brasileira. Rio de Janeiro, 2003; DOHLNIKOFF, M. O Pacto Imperial: Origens do Federalismo no Brasil. São Paulo, Editora Globo, 2005.

${ }^{13}$ CARVALHO, J.M., Entre a Autoridade e a Liberdade. in: CARVALHO, J.M. (ORG), Visconde do Uruguai. São Paulo, Editora 34, 2002..

${ }^{14}$ GRAHAM, R., O Brasil de Meados do Século XIX à Guerra do Paraguai in: Bethell, L. (org.), História da América Latina, Da Independência a 1870. São Paulo, EDUSP e Imprensa Oficial, 2001

${ }^{15}$ Contudo, conforme será tratado no Capítulo 1, Uruguai se posicionou contrariamente à política da conciliação. Seu primeiro pronunciamento público a respeito foi feito em seus discurso no Senado de 28 de maio de 1858 .
} 
Marquês de São Vicente), Direito Público e Análise da Constituição do Império ${ }^{16}$, passando por um intenso debate na imprensa na década de 1860, culminando nos livros de Uruguai e Zacarias. Assim, após a saída do chamado gabinete Saquarema, Uruguai não só continuou atuando no Senado e no Conselho de Estado, mas também se dedicou à redação de seus dois livros (1862 e 1865). Nesse sentido, concordamos com Ivo Coser quanto à sua interpretação de que as obras foram uma forma escolhida pelo Visconde para continuar na política, mas discordamos de sua visão de que fosse a única forma, ou seja, de que ao longo das décadas de 1850 e 1860 ele teria lentamente se afastado do Senado e do Conselho de Estado. ${ }^{17}$

No que tange aos referidos livros, há que se considerar que eles foram redigidos para um determinado público leitor, ou seja, que o balanço que fazia em suas obras de direito, seja da atuação dos saquaremas, seja de outras questões políticas, não era gratuito. Se por um lado, podia, a partir delas, questionar a política da década de 1860 , também podia relatar ao leitor a sua versão dos acontecimentos das décadas anteriores. Além disso, diferentemente de Antonio Joaquim Ribas ${ }^{18}$, a exemplo das obras de Pimenta Bueno, Uruguai não escreveu compêndios para as academias de direito, e sim obras voltadas a um público mais amplo, em que se incluíam tanto seus aliados como seus adversários políticos. Basta lembrarmos que Uruguai foi um dos políticos mais influentes de seu tempo, que fatalmente seria lido, e ele tinha consciência disto ${ }^{19}$. Conforme indica Andréia Slemian ${ }^{20}$, o debate a respeito da centralização política, impulsionado pelas mudanças socioeconômicas pelas quais passou o país na década de 1860, foi sintetizado pelas publicações do Visconde do Uruguai e de Aureliano

\footnotetext{
16 PIMENTA BUEno, J. A. Direito Público Brasileiro e Análise da Constituição do Império. In: KUGELMAS, E. Marquês de São Vicente. São Paulo, Editora 34, 2002.

${ }^{17}$ COSER, I. Visconde do Uruguai, Centralização e Federalismo no Brasil, 1823-1866. Belo Horizonte, Editora UFMG, 2008, p. 322.

${ }^{18}$ RIBAS, A.J. Direito Administrativo Brasileiro: Noções Preliminares. (Obra premiada e aprovada pela Resolução Imperial de 9 de fevereiro de 1861 para uso das aulas das Faculdades de Direito de Recife e São Paulo). Rio de Janeiro, F.L. Pinto \& C. Livreiros-Editores 87, 1866.

${ }^{19}$ Ver CANDIDO, A. Literatura e Sociedade. Coleção Grandes Nomes do Pensamento Brasileiro. São Paulo, Folha de São Paulo, 2000.

${ }^{20}$ SLEMIAN, A. Sob o império das leis: constituição e unidade nacional na formação do Brasil (18221834). São Paulo, Tese de Doutorado, FFLCH/USP, 2006.
} 
Cândido Tavares Bastos ${ }^{21}$, o que corrobora a idéia de que Uruguai tinha consciência de seu público leitor, intervindo diretamente no debate político por meio de suas obras.

Em "O Lavrador e o Construtor", Ilmar Mattos afirma que era por meio de jornais e panfletos que os "mais próximos" - ou seja, a pequena elite política letrada da época - se dirigiam a seus iguais, sendo o Uruguai partidário aplicado desta política de divulgação ${ }^{22}$. Entretanto, neste mesmo artigo, Mattos também afirma que o Ensaio teria sido uma espécie de memória da experiência vivida por seu autor no exercício do governo do Estado, e um livro destinado a polemizar com outras obras então publicadas, especialmente o trabalho de Zacarias de Góis e Vasconcelos, Da Natureza e dos Limites do Poder Moderador. O livro de fato não deixa de ser uma memória, apresentando em alguns pontos um viés autobiográfico que se faz sentir nas interpretações posteriores sobre o Visconde, contudo, um certo conteúdo biográfico não justifica sublimar o fato de que a narrativa dos episódios das décadas de 1830 e 1840 foi justamente redigido em diálogo com os problemas da década de 1860, atribuindo a ambas as obras um caráter propositivo. Não devemos esquecer que Uruguai apresentou sua obra ao Imperador antes mesmo de publicá-la, chegando a ter com ele uma longa discussão sobre alguns pontos do texto, conforme anotou o próprio Pedro II em seu diário. Em suma, não parece despropositado considerá-las mais como respostas aos problemas de seu tempo do que como simples memórias de sua atuação passada.

Entretanto, há que se considerar que não foi gratuita sua opção de se retirar dos gabinetes e de se afastar da tribuna. Discordamos, porém, de José Antonio Soares de Souza, em uma visão que aparece reproduzida na obra de Jeffrey Needell, segundo a qual se tratava apenas de cansaço das lutas partidárias e do desejo de se dedicar à família e aos estudos. Estes estudos tinham um propósito, e nos Estudos Práticos isso fica claro: "Quem ler as citações e exposições que faz este livro há de reconhecer que é o Conselho de Estado quem, na obscuridade, tem trabalhado mais para montar o país e

21 Para uma discussão mais aprofundada do debate entre Uruguai e Tavares Bastos Ver: FERREIRA, G.N. Centralização e Descentralização no Império: o Debate Entre Tavares Bastos e Visconde de Uruguai. São Paulo, Editora 34 e Departamento de Ciência política da USP, 1999. Sobre Tavares Bastos ver também: ABREU, E.S.A. O Evangelho do Comércio Universal: O Desempenho de Tavares Bastos na Liga Progressista e no Partido Liberal (1861-1872). Tese de Doutorado, IFCH/UNICAMP, 2004.

${ }^{22}$ MATTOS, I.R. O Lavrador e o Construtor: O Visconde do Uruguai e a Construção do Estado Imperial in: PRADO, M.E. O Estado Como Vocação: Idéias Políticas no Brasil Oitocentista. Rio de Janeiro, Access, 1999, p.203. 
firmar as boas doutrinas, sem que daí infelizmente tenham sido colhidos notáveis resultados." 23 Ou seja, esta escolha se relacionava com uma vontade de continuar a contribuir para a construção do país, como de seu ponto de vista já fizera quando da aprovação das leis do Regresso. Assim, é fundamental distinguir, como colocado acima, o abandono da política ministerial de um simples afastamento da política.

Desta passagem, podemos pensar que, para o Visconde do Uruguai, esta mudança fora feita em nome de algo maior. Enquanto seus contemporâneos se digladiavam na tribuna ou na imprensa - como fizeram Honório Hermeto e Justiniano José da Rocha, ambos seus amigos ${ }^{24}$, ele optara por se dedicar a uma tarefa que considerava mais nobre e, quem sabe, naquele momento, mais útil, a de construir o país e firmar boas doutrinas, o que se relacionava com a idéia de bem público, que deveria estar acima das paixões políticas.

Para além do problema do suposto ostracismo de Uruguai, há outra questão suscitada pelo debate historiográfico contemporâneo. Gabriela Nunes Ferreira discorda da opinião, defendida por José Murilo de Carvalho e por Ivo Coser, de que o Visconde via o Estado centralizado como "pedagogo da liberdade e educador do povo para o auto-governo"25. Ambos destacam um caráter propositivo nas obras de Uruguai. Ferreira entende que, para Uruguai, civilizar significava estender o raio de ação do Estado, sendo, portanto, o Estado centralizado um fim em si mesmo. Paulino de Souza, para a autora, diferentemente de Tavares Bastos, não possuía um programa de reformas civilizatórias, preocupando-se centralmente com a organização do poder.

\footnotetext{
${ }^{23}$ URUGUAI, V. Estudos Práticos Sobre a Administração de Províncias do Brasil, Rio de Janeiro, Typografia Nacional, 1865, p.p. XLVI-XLVII

${ }^{24}$ Justiniano José da Rocha foi um político conservador, que protagonizou grande parte da oposição que o gabinete da Conciliação sofrera. Em 1855, fez uma série de ataques ao governo a partir do Jornal do Comércio, atacando algumas propostas como a mal-lograda tentativa de reforma judiciária, tentada um ano antes. Seu opúsculo mais famoso de oposição ao gabinete de 1853 denomina-se Ação, Reação e Transação. Para uma discussão mais aprofundada a respeito da oposição de Rocha ao gabinete ver: NEEDELL, J.D. The Party of Order. The Conservatives, the State, and Slavery in the Brazilian Monarchy, 1831-1871. California, Stanford University Press, 2006, p.p. 161-166; ESTEFANES, B.F. Conciliar o Império: Honório Hermeto Carneiro Leão, os partidos e a política de Conciliação no Brasil monárquico (1842-1856). Dissertação de Mestrado, FFLCH/USP, 2010, p.128. Disponível em: http://www.teses.usp.br/teses/disponiveis/8/8138/tde-10012011-122904/fr.php

${ }^{25}$ Ver, CARVALHO, J.M. Entre a Autoridade e a Liberdade, in: CARVALHO, J.M. (org.) Visconde do Uruguai, op.cit.
} 
Segundo relatos do próprio Uruguai, sua viagem à Europa tivera grande influência sobre suas idéias a respeito da centralização. Fiel na defesa da atuação dos conservadores no movimento do Regresso, criticou a atuação dos liberais naquele período, afirmando que as municipalidades haviam sido entregues amarradas às Assembléias Provinciais ${ }^{26}$. Nos Estudos Práticos Sobre a Administração de Províncias do Brasil, Uruguai se dedica a defender as municipalidades: "a menos perigosa escola de liberdade? É preciso dar-lhes liberdade, e que não sejam meras pupilas no que lhes é mais peculiar. (...), nenhum povo pode ser livre sem instituições livres municipais. Que o digam a Inglaterra e os Estados Unidos". 27

Paralelamente, Uruguai destaca que misturar o sistema norte-americano com o nosso seria fazer com que ambos se destruíssem mutuamente, instaurando a anarquia no país (haja vista a experiência da Regência). Entretanto, ressalva que seria conveniente ir concedendo aos poucos o self-government com os necessários ajustes para habituar o povo a uma liberdade séria e tranqüila ${ }^{28}$. Contudo, sua defesa do selfgovernment não o impede de reafirmar a importância do elemento monárquico. Uruguai não os vê como excludentes, ao contrário, entende a monarquia como elemento que garante a liberdade e a civilização. O fato de, em sua opinião, o modelo francês ser mais aplicável ao Brasil que o inglês e o norte-americano, não impede que o governo, por meio de instituições administrativas e da instrução pública, desenvolva na população o espírito público, permitindo que lentamente se caminhe na direção do modelo adotado pelos Estados Unidos e pela Inglaterra. Neste sentido, assemelha-se a Tavares Bastos, para quem a admiração do modelo norte-americano nunca significou uma adesão ao republicanismo. Nesse sentido, José Murilo de Carvalho aponta, quanto a essa aparente contradição do Visconde, o caráter propositivo de suas idéias.

A resposta de Uruguai é manter a centralização política, mas promover lentamente a descentralização administrativa, melhorar a qualidade do governo provincial e, sobretudo, introduzir aos poucos o autogoverno municipal. 'É preciso ir educando o povo, habituando-o, pouco a pouco, a gerir seus próprios negócios'. O governo deveria adotar uma atitude pedagógica em relação ao autogoverno: ir transferindo aos poucos

\footnotetext{
${ }^{26}$ URUGUAI, V. Estudos Práticos Sobre a Administração de Províncias do Brasil, Rio de Janeiro, Typographia Nacional, 1865. p. IX

${ }^{27}$ URUGUAI, V. Estudos Prático .. op.cit. .p. XI

${ }^{28}$ URUGUAI, V. Ensaio ... op.cit. p.498.
} 
poderes e atribuiç̧ões para que as pessoas se acostumassem ao exercício da autoridade com liberdade. ${ }^{29}$

Assim, consideramos que, mesmo não possuindo um projeto de reformas formalmente escrito, isso não implica sua inexistência e muito menos sua inação frente aos acontecimentos políticos. Ademais, vale dizer que, se as Bases - que constituíram a primeira redação de uma série de propostas que seriam desenvolvidas em suas obras não constituíam propriamente um projeto, elas representavam, sem dúvida alguma, propostas efetivas de reforma.

Portanto, o afastamento da política ministerial deve ser tomado em suas justas dimensões. Alguém efetivamente disposto a abandonar a política não participaria, como Uruguai, por duas vezes (1857 e 1858), como Plenipotenciário de negociações com países vizinhos, nem escreveria obras de viés político com uma clara referência ao período em que se encontrava. Conforme será discutido ao longo dessa dissertação, tais obras mostram claramente suas propostas de reforma no tocante à organização administrativa e à centralização política. A partir dessas propostas, é possível notar que, para Uruguai, o Estado possuía importante função pedagógica, pois seria o governo quem educaria o povo para o self-government.

Mas é preciso ir mais além, pois, a despeito da importância inconteste de suas obras, as proposições e a atuação política, entre 1853 e 1866, têm como espaço privilegiado sua participação junto ao Senado e ao Conselho de Estado, e mesmo na correspondência que travou com outras figuras políticas do Império. Ou seja, considerando-se a centralidade de Uruguai no período imperial, torna-se necessário entender de que maneira ele interferiu na política de sua época, possuindo (ou não) projetos que se diferenciavam daqueles formulados pelos ministros dos gabinetes da conciliação e mesmo da Liga Progressista. Nas palavras do próprio Uruguai: “... o meu trabalho, quando mais não sirva, poderá provocar o exame e a discussão, os quais somente podem trazer melhoramentos reais e sérios." 30

Assim, para compreender a atuação política do Visconde do Uruguai entre a subida do ministério da Conciliação e o ano de sua morte, é necessário, primeiramente,

${ }^{29}$ CARVALHO, J.M. Entre a Autoridade e a Liberdade in: CARVALHO, J.M. (org.), op.cit. p.35.
${ }^{30}$ URUGUAI, V. Ensaio... op.cit. p.74 
analisar o contexto da queda do gabinete Saquarema, as divergências que havia dentro do Partido Conservador, e como as propostas de reforma da conciliação desagradaram os ministros do gabinete anterior. Conforme será discutido no Capítulo 1, com a nomeação de Honório Hermeto Carneiro Leão (futuro Visconde e depois Marquês do Paraná) como Presidente de Pernambuco, ficou evidente a divergência dele com o gabinete $^{31}$, que desejava uma intervenção de Honório em favor de seus candidatos. Contudo, não somente Honório desejava uma maior lisura no processo eleitoral, mas o próprio Imperador também.

Como o gabinete não se dispunha a levar a cabo a política de não-intervenção nos pleitos, seus ministros apresentaram um pedido de exoneração coletiva. Não atendido ao pedido, o Imperador fez pequenas alterações no gabinete, colocando Rodrigues Torres na Presidência do Conselho de Ministros, em substituição a Monte Alegre em 11 de maio de 1852. Em 1853, ascendeu o chamado gabinete da Conciliação, presidido pelo Marquês do Paraná. Com sua morte, em 1856, foi substituído interinamente por Luís Alves de Lima e Silva (futuro Duque de Caxias) em 3 de setembro de 1856. Saindo esse gabinete, o Imperador chamou o Visconde do Uruguai para presidir o Conselho de Ministros. Diante da recusa de Uruguai, foi nomeado o Marquês de Olinda em 4 de maio de 1857. Olinda, por Aviso de 19 de agosto de 1857, instituiu uma comissão encarregada de elaborar um projeto para melhorar as administrações provinciais, conforme se discutirá no Capítulo 2. Nas Bases, Uruguai expressa de maneira clara seu projeto de regulamentação da justiça administrativa, propondo uma organização de primeira e segunda instância para o contencioso administrativo, mas também defende, conforme questão apresentada por Olinda, a criação de Conselhos de Presidência de Província.

\footnotetext{
31 Trata-se do chamado gabinete Olinda-Monte Alegre, que ascendeu ao poder em 29 de setembro de 1848. A 6 de outubro de 1849, Olinda retirou-se do gabinete, assumindo o Visconde de Monte Alegre. Esse gabinete contava com Monte Alegre na Presidência do Conselho de Ministros e no Ministério do Império; Euzébio de Queiroz Coutinho Matoso Câmara no Ministério do Império; Paulino José Soares de Souza no Ministério dos Negócios Estrangeiros (em substituição a Olinda); Joaquim José Rodrigues Torres (futuro Visconde de Itaboraí), também em substituição a Olinda; Manuel Vieira Tosa no Ministério da Marinha e Manuel Felizardo de Souza Melo no Ministério da Guerra. JAVARI, Barão, Organizações e Programas Ministeriais. Regime Parlamentar no Império. Rio de Janeiro, Arquivo Nacional, 1962, p.p. 104-105.
} 
Finalmente, há que se contextualizar a situação de redação de suas obras, em que defende - no caso dos Estudos Práticos - uma reforma do Ato Adicional, conferindo poderes ao governo de anular sanções dadas pelos presidentes a leis provinciais, e - em se tratando do Ensaio - uma maior autonomia às municipalidades, em detrimento das Assembléias Provinciais, paralelamente a um papel mais ativo do Imperador na política. Nesse sentido, para se entender suas propostas de reforma, suas obras não podem ser analisadas isoladamente. Seus pareceres e seus discursos mostram, por exemplo, como ele não era totalmente avesso à esfera provincial, ou seja, que entendia ser necessário, isso sim, redimensionar o espaço de cada esfera de governo.

Por essas razões, para um melhor entendimento de suas obras e de sua própria atuação política no período considerado de ostracismo, faz-se necessário recuperar o contexto de seu afastamento em relação à política ministerial, retornando ao gabinete de 29 de setembro de 1848, para, a partir daí, reconstruir seu percurso nos anos posteriores.

Assim, a presente dissertação visa elucidar qual teria sido o projeto de Uruguai para o Brasil nas décadas de 1850 e 1860 . Entendemos aqui por projeto político aquilo que os políticos imperiais e, em especial, aqueles que tomaram parte nas discussões e proposições das décadas de 1830 e 1840 - “construtores do Império"332 como o próprio Paulino - desejavam para a organização do Estado nacional, o que não implicava necessariamente uma sistematização em um cronograma de reformas. Projeto político, naquele contexto, era algo passível de se inferir a partir das idéias expressas por esses políticos nos mais diferentes espaços nos quais atuavam.

Finalmente, uma vez que propomos tanto a contextualização das obras do Visconde do Uruguai como a revisão da idéia de seu afastamento da política, expressa pela maioria dos autores que dele trataram - e que, como exposto acima, começou a ser

\footnotetext{
${ }^{32} \mathrm{O}$ termo construtores do Império refere-se à formulação de Ilmar Rohloff de Mattos, para quem os saquaremas não somente imprimiram uma direção política ao Império, mas também uma direção intelectual e moral. Mattos considera a Conciliação como obra dos saquaremas. Todavia, a idéia de que os saquaremas foram construtores do Império é controversa. Pesquisas recentes como a de Miriam Dohlnikoff apontam que o arranjo político-institucional estabelecido em 1832, e materializado em 1834 com o Ato Adicional, que criou as Assembléias Legislativas Provinciais, criou uma esfera provincial de poder, que, mesmo com as reformas do Regresso, não foi anulada. Outras pesquisas, como as de Jeffrey Needell, Roderick Barman e Bruno Fabris Estefanes mostram que a Conciliação, ao invés de obra dos saquaremas, ocorreu à sua revelia, traduzindo mais uma política do próprio Imperador.
} 
construída pelo próprio Visconde em cartas e em sua autobiografia -, é necessário esclarecer as idéias que esposamos a respeito decontextualização e detrabalho de viés biográfico.

A seguir Quentin Skinner, contextualizar não implica colocar ênfase na política, com vistas a entender, e.g., a obra de Thomas Hobbes, mas sim situar sua produção no debate de idéias de seu tempo. Para Skinner, uma palavra possui um determinado significado numa certa época, o que implica que uma pesquisa sobre idéias do passado deva levar isto em consideração para não correr o risco de chamar os seus enunciadores a debates dos quais eles não poderiam ter participado. Assim, segundo o autor, é preciso investigar a quê ou a quem os argumentos visavam, levando-se em conta o vocabulário político da época. Esta concepção de Skinner, , é fundamental se quisermos entender as obras do Visconde do Uruguai, pois ele estava dialogando tanto com outras obras de autores contemporâneos, como com a própria política que se expressava na tribuna, na imprensa e na documentação oficial do governo ${ }^{33}$.

A biografia como ferramenta de investigação histórica remonta a um debate do início do século XX. Na Europa, após a Primeira Guerra Mundial, ganhou corpo a discussão acerca da chamada biografia moderna, associada ao relativismo ético, à psicanálise e às transformações da epistemologia histórica ${ }^{34}$. No Brasil, entre 1930 e 1950, a biografia foi pensada com a função pedagógica de instruir os leitores nos saberes da nação brasileira. Aqui se inserem as obras de Octávio Tarquínio de Souza ${ }^{35}$ e José Antônio Soares de Souza ${ }^{36}$.

$\mathrm{Na}$ segunda metade do século XX, esse debate ganhou mais atenção e elaboração com diversas abordagens críticas. Em 1968, Pierre Bourdieu, em parceria com Jean Claude Passeron, estabeleceu o princípio da não-consciência, que reza que as relações sociais não podem se reduzir a ligações entre subjetividades animadas por intenções ou motivações, porque elas se estabelecem entre condições e posições sociais e possuem, dessa forma, mais realidade que os sujeitos que ela liga entre si. Bourdieu

\footnotetext{
33 SKINNER, Q. Meaning and Understanding in the History of Ideas. In: History and Theory, Vol.8, $\mathrm{n}^{\circ} 1$ (1969), p.p. 3-53. Publicação da Wesleyan University.

${ }^{34}$ GONÇALVES, M.A., Narrativa Biográfica e Escrita da História: Octávio Tarquínio de Sousa e seu Tempo. in: Revista de História 150 (1 2004). MADELÉNAT, La Biographie. Paris, PUF, 1984.

${ }^{35}$ SOUZA, O.T., História dos Fundadores do Império do Brasil .Rio de Janeiro, José Olímpio, 1957.

${ }^{36}$ SOUZA, J. A. Soares de. A vida ... op.cit.
} 
critica a necessidade que muitos pesquisadores sentem de atribuir um sentido à vida do biografado. Deste equívoco ocorre o que ele chama de ilusão biográfica.Para se prevenir dela, o pesquisador deve situar claramente os agentes em seu grupo social e se esforçar por destacar de modo claro a construção diacrônica da trajetória dos grupos nos diversos campos ${ }^{37}$. A biografia independe do indivíduo, relaciona-se com o agente operando em um campo de forças, muitas vezes sem atinar para o sentido real de sua $\mathrm{ação}^{38}$.

As discussões sobre biografia abertas por Bourdieu e Passeron foram foco de atenção de Giovanni Levi. No artigo, "Usos da Biografia", Levi propõe uma abordagem diferente da de Bourdieu. Em sua opinião, é necessário atentar para as relações entre normas e práticas e, principalmente, para as próprias contradições dos sistemas de normas, que apresentam também incoerências, abrindo a partir delas diversas possibilidades de ação aos sujeitos ${ }^{39}$. Para ele, nenhum sistema normativo é suficientemente estruturado a ponto de eliminar todas as possibilidades de escolha consciente, de manipulação ou de interpretação das regras de negociação. Daí deriva, segundo Levi, uma perspectiva que, embora não seja contraditória, apresenta-se como diferente da de Bourdieu, pois, para Levi, o autor de "A Ilusão Biográfica" estaria mais preocupado com os elementos inconscientes e de determinação do que com as contradições dos sistemas normativos ${ }^{40}$. Para Levi, as contradições nas regras permitem que a repartição desigual do poder, por mais coercitiva que seja, abra espaços de manobra por meio dos quais os dominados podem impor aos dominantes mudanças que não são desprezíveis ${ }^{41}$.

Assim, seguindo a proposta de Skinner, pretendemos contextualizar as obras de Uruguai a partir do diálogo que estabelecem com outros textos de seu tempo. Isso traz a necessidade de analisar que autores da época iniciaram os debates nos quais as obras de

\footnotetext{
${ }^{37} \mathrm{O}$ conceito de campo na análise bourdiesiana diz respeito a uma diferenciação em um espaço social. Cada um desses campos possui uma lógica própria que determina as disputas de poder em seu interior. Há assim, o campo literário, dos esportes, político, econômico, etc. Ver BOURDIEU, P. O Poder Simbólico. Rio de Janeiro, Bertrand Brasil, 1998.

38 MADELÉNAT, La Biographie. Paris, PUF, 1984. MONTAGNER, M.A. Trajetórias e biografias: notas para uma análise bourdiesiana in: Sociologias, ano 9, nº 17, jan./jun. 2007, p.p. 251-255.

${ }^{39}$ LEVI, G. Usos da Biografia in: FERREIRA, Marieta de Moraes \& AMADO, Janaína (orgs.), Usos e Abusos da História Oral. Rio de Janeiro, Fundação Getúlio Vargas, 1996, p. 179.

${ }^{40}$ LEVI, G. Usos da Biografia... op.cit. p.180.

${ }^{41}$ LEVI, G. Usos da Biografia... op.cit. p.180.
} 
Uruguai se inserem, quais os autores cujas idéias ele combatia ou com cujas idéias concordava, bem como a repercussão que os livros de Uruguai tiveram, fazendo com que outros fossem escritos para combatê-lo. Nesse contexto, conforme será analisado ao longo da dissertação, inserem-se as obras de Pimenta Bueno, Antonio Joaquim Ribas, Zacarias de Góes e Vasconcelos e Aureliano Cândido Tavares Bastos, entre outros autores. O contexto dessas obras, conforme dito, sugere que sua escrita foi uma forma de atuação política, contrariando o discurso autobiográfico de Uruguai e as biografias que se sucederam. Isto também implica o desafio de se evitar a chamada “ilusão biográfica”, levando em conta como o indivíduo pode atuar sem estar completamente atado a um sistema de regras que tornaria suas ações totalmente previsíveis.

Nas páginas anteriores, destacamos várias questões acerca da atuação política do Visconde do Uruguai e da fortuna crítica de suas obras. Entre os problemas centrais aos quais se dedicou merecem especial destque as questões ou proposições acerca da centralização política, da organização administrativa, da escravidão e do Poder Moderador

Tomando tais questões por fio condutor, a presente dissertação está organizada em quatro capítulos. No primeiro capítulo, buscamos discutir a visão de Uruguai acerca do papel ativo do monarca na condução da política, mas que não necessariamente implicava uma atitude mais assertiva na condução dos gabinetes. Partimos, então, de uma aparente contradição de Uruguai que, em 1851, posicionou-se contrariamente a uma maior intervenção de Dom Pedro II no Poder Executivo, mas que, em 1862, no "Ensaio", defendeu arduamente o Poder Moderador como privativo do monarca, um Poder sobre o qual os ministros não poderiam ter qualquer influência. Nessa defesa do papel do Poder Moderador, Uruguai advoga uma atuação efetiva do Imperador na condução dos negócios públicos. Contudo, essa contradição parece mais aparente do que efetiva, pois defender que o monarca tenha o pleno gozo do Poder Moderador não significava defender o mesmo em relação ao Poder Executivo, que, pela Constituição, era chefiado pelo monarca que o exercia por meio dos ministros.

No que diz respeito à agenda de reformas, elaficou bastante explicitada no seu projeto das Bases, em que sistematizou como desejava ver organizado o contencioso 
administrativo e propôs o caminho para se chegar a essa organização. Vale destacar, como fazia o próprio Visconde, que, no Império do Brasil, o contencioso administrativo encontrava-se organizado somente no âmbito da Fazenda. Nos demais ministérios, o presidente de Província decidia por si próprio as questões contenciosas que chegavam até ele, sendo possível apelação ao ministro de Estado e, por último, ao Conselho de Estado. O que Uruguai buscava era a organização do contencioso administrativo em primeira e segunda instância, seguindo os devidos ritos processuais, até que chegasse ao Conselho de Estado. Ele defendia ainda a criação de comissários dos presidentes nas localidades, a recriação dos Conselhos de Presidência de Província e a organização de uma Seção do Conselho de Estado encarregada somente de examinar os casos do contencioso administrativo. Essa sua proposta, que aparece também em diversos pareceres emitidos como membro do Conselho de Estado, será o objeto de discussão do Capítulo 2, "Razão de Estado, direitos e interesses".

A polêmica na qual esteve envolvido com Tavares Bastos dizia respeito à questão da centralização política. Este tema está presente em todos os seus livros. No Ensaio, Uruguai deixa em aberto a possibilidade de uma organização do Estado Nacional diferente daquela que então existia e que ele ajudara a montar, sugerindo, por exemplo, que o governo poderia ir aos poucos introduzindo o self-government para habituar o povo a reger seus próprios negócios ${ }^{42}$. Estas idéias foram tratadas mais detidamente no último livro de Uruguai, os Estudos Práticos, em que clama por uma reforma do Ato Adicional.

Como já mencionado, Uruguai manteve-se ativo como senador e conselheiro de Estado. No Senado, foi membro da Comissão de Assembléias Provinciais, onde elaborou o projeto das Bases. No Conselho de Estadocontinuou sendo Relator de inúmeras consultas da Seção de Justiça e Negócios Estrangeiros. A documentação por ele produzida nos espaços institucionais nos quais continuou atuando, após sua saída do chamado gabinete saquarema, são fundamentais para compreender suas idéias. No tocante à divisão de competências entre centro, províncias e localidades, isso fica especialmente nítido, pois foi justamente em uma discussão do Conselho de Estado

\footnotetext{
${ }^{42}$ URUGUAI, V. Ensaio Sobre o Direito Administrativo. in: CARVALHO, J.M. (ORG), Visconde do Uruguai. São Paulo, Editora 34, 2002, p.498.
} 
Pleno e em uma sessão do Senado que defendeu o direito das Assembléias Provinciais de legislarem sobre corpos policiais, inclusive estabelecendo jurisdições de primeira e segunda instância para julgá-los ${ }^{43}$. Ora, a complexidade dessa discussão não possibilita que nos conformemos com a opinião de que a centralização seria, para ele, um fim em si mesmo. O que nos parece é que se trata de um meio para se chegar a um outro modelo de organização do Estado Nacional, no qual as Províncias não tivessem tanta força como a revisão de 1834 lhes dera. Essas questões serão discutidas detidamente no capítulo 3, "Pelo Império, Contra a Província".

A necessidade de se ampliar as fontes de pesquisa quando investigamos as idéias de Uruguai se torna ainda mais evidente quando analisamos o seu pensamento a respeito da escravidão, uma vez que ele não a menciona em suas famosas obras. Contudo, seus discursos parlamentares e seus pareceres na Seção de Justiça constituem fontes imprescindíveis para compreender o que ele pensava a respeito de tal instituição. A despeito do silêncio de suas obras, a análise de suas idéias sobre a escravidão é importante para a reflexão sobre seu projeto, pois reconhecia os cativos como homens, defendendo que tivessem as mesmas garantias processuais que qualquer outra pessoa, a despeito de ter se posicionado favoravelmente ao contrabando nos anos que antecederam a aprovação da chamada lei Eusébio de Queiroz. Suas idéias a respeito da escravidão também são importantes para o entendimento de seu projeto na medida em que mostram de maneira clara sua vinculação com os interesses da classe proprietária de cafeicultores do Rio de Janeiro. Para defender os interesses desse grupo, Uruguai se valia do discurso do liberalismo escravista. Ou seja, a exemplo dos Estados Unidos, baseava-se na idéia de que era possível haver um Estado liberal moderno convivendo com a escravidão. O pensamento de Uruguai a respeito da instituição do cativeiro será o tema do Capítulo 4, Contrabando, Propriedade e Direitos: o Problema da Escravidão.

\footnotetext{
${ }^{43}$ Ata de 22 de fevereiro de 1862. In: RODRIGUES, J. H. (ORG.) Atas do Conselho de Estado Pleno, Terceiro Conselho de Estado (1857-1864). Brasília, Senado Federal, 1978, p.p. 156-161; Anais do Senado, Sessão de $1^{\circ}$ de junho de 1854 . Volume 2, p.p. 13-14.
} 


\title{
CAPÍTULO 1: O PODER MODERAdOR E A INTERFERÊNCIA DO MONARCA NO EXECUTIVO
}

\begin{abstract}
Os Ministros de Vossa Majestade Imperial compreenderam o seu pensamento e que Vossa Majestade Imperial tinha resolvido, em Sua Alta Sabedoria, pôr termo a um sistema de reações e concessões que pode, sim dar temporariamente um acréscimo de força factícia a um Ministério ou a um partido, mas cuja continuação abismaria por fim o País. E isto quando o mundo está em agitação, na época revolucionária em que vivemos, quando, em vez de irritar convém acalmar. [...] Depois de três anos de uma luta continuada com sempre renascentes dificuldades, os Ministros de Vossa Majestade Imperial receiam não ter fortaleza bastante para atravessar com vantagem pública a próxima Sessão Legislativa e a crise de eleições. É do seu dever fazer a Vossa Majestade Imperial essa declaração e implorar a Vossa Majestade Imperial a sua substituição por outros. ${ }^{44}$
\end{abstract}

Com estas palavras, no dia 15 de novembro de 1851, o gabinete que ascendera ao poder em 29 de setembro de 1848, no qual Paulino ocupava a pasta dos Negócios Estrangeiros, pedia sua exoneração coletiva. O sistema ao qual dom Pedro II havia resolvido pôr termo era, conforme o que se depreende da análise do documento dos ministros demissionários, o das eleições que ocorriam, de modo geral, ao gosto de quem estivesse no gabinete. Segundo eles, à época da maioridade, o monarca teria encontrado um governo fraco que, para conseguir se manter, necessitava fazer concessões que o deixavam dependente de influências das localidades, "as mais das vezes criadas e alimentadas pela força que tiravam do governo" ${ }^{45}$. Com isso, os apoiadores dos partidos nas localidades podiam fazer suas exigências, que tinham que

\footnotetext{
${ }^{44}$ Exoneração Coletiva do Ministério. Assinam o documento: (nome próprio e depois título entre parenteses) Visconde de Monte Alegre, Euzébio de Queiroz Coutinho Matoso Câmara, Joaquim José Rodrigues Torres, Paulino José Soares de Souza, Manuel Filizardo de Souza e Melo e Manuel Vieira Tosta em 15 de novembro de 1851. Documento publicado em: VIANNA, H. Vultos do Império. São Paulo, Ed. Nacional, 1968, pp. 149-153.

${ }^{45}$ VIANNA, H. op.cit. São Paulo: Nacional, 1968, p.49.
} 
ser mais ou menos satisfeitas. Após as rebeliões liberais de 1842, de acordo com os demissionários, os saquaremas teriam desmontado seus adversários nas províncias, e montado as administrações com seus aliados. Ainda no entendimento dos ministros, ao subir o gabinete de 2 de fevereiro de 1844, este encontrara as províncias aparelhadas com aliados dos saquaremas. Diante deste quadro, o gabinete liberal passou a nomear, para os diversos cargos, pessoas que prestassem apoio aos seus candidatos. Este sistema, no entendimento dos ministros, desmoralizava profundamente o país. Todavia, os signatários do documento afirmavam que no estado no qual o país se encontrava, nenhum ministério podia prescindir do apoio de um dos partidos. Nesta lógica, ao retornarem ao poder em 29 de setembro de 1848, os saquaremas tiveram de administrar as reclamações de seus aliados que haviam perdido o emprego e as posições durante os vários gabinetes liberais que, com suas diversas políticas correspondem ao chamado qüinqüênio liberal. Isto colocava um problema, pois "se não satisfizesse essas exigências, descontentaria aqueles de quem unicamente poderia esperar apoio e daria assim uma grande força aos seus adversários" ${ }^{\text {46 }}$.

Também de acordo com os ministros, o imperador sempre fora oposto a este sistema, ao qual, como citado na epígrafe, desejava pôr termo. Contudo, os ministros ponderavam que esta mudança que o monarca desejava os faria perder muita força, e que desgostaria aqueles que os podiam apoiar na época das eleições. Assim, consideravam que para a luta que necessitaria travar, seria necessário que o Imperador nomeasse um novo ministério, com “espíritos mais repousados". Sob esse pretexto, recusavam-se a seguir a política desejada pelo monarca. Ante a recusa de seus ministros, ao invés de nomear o gabinete mais repousada ao qual eles aludiam, o imperador modificou a composição do ministério somente seis meses depois, mas mantendo os principais quadros políticos que se recusavam a dar anuência à sua política. Com isso, em 11 de maio de 1852, foi nomeado Rodrigues Torres como presidente do Conselho de Ministros.

\footnotetext{
${ }^{46}$ VIANNA, H. op.cit. São Paulo: Nacional, 1968, p.50.
} 


\section{1 - A POLÍtiCA DE CONCILIAÇÃo E A INTERFERÊNCIA dO MONARCA}

O gabinete que ascendeu ao poder em 29 de setembro de 1848 contava com a chamada trindade saquarema ${ }^{47}$ em seus quadros. Inicialmente presidido pelo Visconde de Olinda, este foi substituído na presidência do Conselho pelo ministro do Império, o Visconde de Monte Alegre em 8 de outubro de 1849. Além disso, o gabinete contava com Euzébio de Queiroz na pasta Justiça, o Visconde de Olinda acumulando o Ministério dos Negócios Estrangeiros e o da Fazenda, e Manoel Felizardo de Souza Melo acumulando a Guerra e a Marinha. Manoel Felizardo foi substituído no comando da Marinha por Manuel Vieira Tosta (futuro Barão de Muritiba) em 23 de julho de 1849. Com a saída de Olinda em outubro de 1849, Paulino José Soares de Souza assumiu os Negócios Estrangeiros e Joaquim José Rodrigues Torres passou a responder pela Fazenda ${ }^{48}$.

Este gabinete teve de enfrentar diversas questões como o fim do tráfico de escravos intercontinental, as questões platinas contra Rosas e Oribe, além da Rebelião Praieira em Pernambuco. No cerne da Praieira estavam as inversões que as mudanças de gabinetes causavam na política provincial.

Segundo Izabel Marson, o movimento praieiro divide-se em dois períodos: um mais geral, compreendido entre 1842 e 1849, e outro, inserido dentro do primeiro, que é de 1848 a 1849. Segundo a autora, "o controle dos cargos políticos e policiais" foi o motivo imediato para a deflagração do conflito armado ${ }^{49}$. Disso, Bruno Fabris Estefanes considera que "o recurso às armas em 1848 só pode ser entendido dentro de um período mais longo de confrontamento dos partidos, para os quais a questão das nomeações fez-se crucial" ${ }^{, 50}$. Estefanes aponta que entre 1835 e 1832 predominara uma coalizão política em Pernambuco, que tornava muito diminuta as clivagens na elite

\footnotetext{
47 Euzébio de Queiroz Coutinho Matoso da Câmara, Paulino José Soares de Souza e Joaquim José Rodrigues Torres.

48 JAVARI, Barão. Organizações e Programas Ministeriais. Regime Parlamentar no Império. Rio de Janeiro: Arquivo Nacional, 1962, p.p. 104-105.

49 MARSON, I.A. Movimento Praieiro: imprensa, ideologia e poder político. São Paulo: Moderna, 1980, p.1.

${ }^{50}$ ESTEFANES, B.F. Conciliar o Império: Honório Hermeto Carneiro Leão, os partidos e a política de Conciliação no Brasil monárquico (1842-1856). Dissertação de Mestrado, FFLCH/USP, 2010, p.126. Disponível em: http://www.teses.usp.br/teses/disponiveis/8/8138/tde-10012011-122904/fr.php
} 
proprietária pernambucana, especialmente devido à aproximação das famílias Cavalcanti e Rego Barros, das quais saíram os dois presidentes de Pernambuco durante oito anos ${ }^{51}$.

Todavia, conforme aponta o referido autor, em 1842 essa aliança entre as duas famílias se rompeu a partir da oposição ao governo de Francisco do Rego Barros (Barão da Boa Vista, governou Pernambuco de 7 de dezembro de 1841 a 4 de junho de 1844). Organizada a partir da Assembléia Legislativa de Pernambuco, essa oposição fez sentir seus ecos no Legislativo central. Segundo Estefanes, os dissidentes se denominavam Partido Nacional de Pernambuco. Os partidários de Boa Vista se referiam aos seus adversários como praieiros, em referência à Rua da Praia, onde localizava-se a tipografia que dava corpo ao Diário do Povo, jornal praieiro. Os praieiros, por sua vez referiam-se aos simpatizantes do presidente da Província como "guabirus", que, segundo Marcus Carvalho "é um rato cinza, que se empertiga todo quando ameaçado. É conhecido por ser ladrão de lixo e de comida"52. Segundo Estefanes, a configuração partidária de Pernambuco ficou da seguinte forma: os guabirus eram identificados com os conservadores; os praieiros inicialmente se identificavam com a tendência liberal. Contudo, dada a proeminência dos Cavalcanti nesse campo, os praieiros romperam também com os liberais, constituindo partido independente. $\mathrm{O}$ referido autor aponta três magistrados como os principais nomes da revolta: Peixoto de Brito; Urbano Sabino Pessoa de Mello e Antonio Nunes Machado ${ }^{53}$. Todos estavam acomodados no governo de Rego Barros até se tornarem dissidentes. A eleição legislativa de 1842, feita sob os auspícios da Lei de 3 de dezembro de 1841 e respectivos regulamentos alijou a oposição a Rego Barros dos cargos que ocupava.

A referida Lei reformou o Código de Processo Criminal do Império, dotando o Ministério da Justiça de um grande número de cargos policiais e judiciários, cuja nomeação dependia do ministro, o que lhe permitia negociar esses cargos em troca de apoio aos seus candidatos. Segundo Thomas Flory, a reforma alterou substancialmente a organização da Justiça. O Ministro da Justiça nomeava os Presidentes de Província e

\footnotetext{
${ }^{51}$ ESTEFANES, B.F. Conciliar o Império ... op.cit. p.126.

${ }^{52}$ CARVALHO, M.J.M. A Insurreição Praieira in: Revista Almanack Braziliense, n. 8, nov. de 2008, p. 17. Disponível em: www.almanack.usp.br.

${ }^{53}$ ESTEFANES, B.F. Conciliar o Império ... op.cit. p.127.
} 
os Chefes de Polícia, sendo estes últimos escolhidos entre desembargadores e juízes de direito. O Chefe de Polícia nomeava os Delegados no âmbito do município e recomendavam ao Chefe de Polícia os Subdelegados no nível dos distritos ${ }^{54}$. Com a reforma do Código de Processo, o chefe de polícia ficava encarregado da formação da culpa e do processo para ser enviado ao juiz de direito. Nas localidades, ele fazia isto por meio de seus agentes, ou seja, os delegados e os subdelegados. Fora isso, o governo central nomeava os Juízes Municipais nos Termos, e no âmbito das comarcas nomeava os Juízes de Direito, que tiveram sua funções ampliadas, devendo ser nomeados entre bacharéis formados que tivessem sido juízes municipais, juízes de órfãos e promotores por pelo menos quatro anos ${ }^{55}$. Apesar de o governo do Rio de Janeiro ter à sua disposição diversos cargos policiais e judiciais, Miriam Dohlnokoff aponta que essa reforma não alterou o arranjo político-institucional estabelecido em 1832 e institucionalizado no Ato Adicional de 1834. Segundo a autora, o controle das eleições permanecera com as autoridades eletivas, pois a Mesa Eleitoral continuava presidida pelo Juiz de Paz e mais quatro eleitores da paróquia, possuindo poder inclusive para contestar a identidade dos votantes, sem que houvesse recurso de suas decisões. Portanto, as autoridades criadas com a Lei de 3 de dezembro não tiravam o controle eleitoral das localidades ${ }^{56}$. Contudo, municiava o governo com cargos que poderia oferecer em troca de apoio. Ademais, se isso não assegurava um controle total das eleições, permitia ao gabinete que sua influência se fizesse sentir nas eleições, ao ponte de os gabinetes de maneira geral conseguirem eleger Câmaras que lhes fossem dóceis.

No caso específico da Praieira é nítido como a questão dos cargos teve um peso importante. Segundo Marcus Carvalho, os Praieiros assumiram o poder na província em 1845. Uma vez no comando, procuraram alijar os guabirus do poder na Província. Assim, procederam à demissão de mais de 650 autoridades na polícia e na Guarda

\footnotetext{
${ }^{54}$ O Império Brasileiro dividia-se juridicamente na seguinte hierarquia: Distritos Judiciais, de competência do Supremo Tribunal de Justiça, atuante em todo o Império; Províncias, Comarcas; Termos; Municípios; Distritos de Subdelegacia e de Paz e Quarteirões. Ver RAMALHO, J.I. Elementos do processo criminal: para uso das faculdades de direito do império. São Paulo : Dous de Dezembro, 1856. ${ }^{55}$ Ver FLORY, FlORY, El Juez de Paz y El Jurado em El Brasil Imperial, 1808-1871 Control y estabilidad política en el Nuevo Estado. México: Fóndo de Cultura Económica, 1986, p.p.266-267.

${ }^{56}$ DOHLNIKOFF, M. O Pacto Imperial: Origens do Federalismo no Brasil. São Paulo, Editora Globo, 2005, p.p. 108-109.
} 
Nacional, promovendo o que o referido autor denominou como "gangorra política."57 Em decorrência disto, conforme aponta Bruno Estefanes os conflitos que marcaram a década de 1840 pernambucana em decorrência da "gangorra" tiveram no seu âmago "o uso dos cargos do governo, sobretudo os policiais, para impor-se aos adversários pessoais" ${ }^{\prime \prime 8}$.

Foi no desenrolar da Praieira que se demonstrou uma cisão entre os conservadores, que é fundamental para o entendimento da visão de Uruguai sobre as relações do Imperador com o Poder Executivo e o Poder Moderador ${ }^{59}$. A subida do gabinete conservador em 1848 significou um novo movimento da "gangorra" em Pernambuco, pois, os praieiros foram alijados do poder da província, iniciando-se, contra eles, uma série de perseguições legitimadas pelo aparato policial do Estado. A revolta estourou com a prisão de um delegado praieiro desituído ${ }^{60}$.

O governo imperial nomeou Manuel Vieira Tosta (futuro Barão de Muritiba) como Presidente de Pernambuco com a finalidade de reprimir militarmente a revolta ${ }^{61}$. Em fevereiro de 1849 os rebeldes praieiros decidiram atacar o Recife por considerarem que a capital da Província estaria desguarnecida devido aos combates travados no interior. Contudo, a o ataque ao Recife foi reprimido. Após esse malogro, a rebelião já estava praticamente sufocada, permanecendo ainda alguns focos de resistência no interior da Província, comandados pelo Capitão de artilharia Pedro Ivo Velloso da Silveira ${ }^{62}$.

${ }^{57}$ CARVALHO, M.J.M. A Insurreição Praieira ... op.cit. p. 18.

${ }^{58}$ ESTEFANES, B.F. Conciliar o Império ... op.cit. p.128.

${ }^{59}$ Para uma análise mais detida da praieira ver os já citados trabalhos de Bruno Fabris Estefanes e Marcus Carvalho e o de Izabel Marson: MARSON, I.A. O Império do Progresso. A revolução praieira em Pernambuco (1842-1855). São Paulo: Brasiliense, 1987. e MARSON, I.A. Movimento Praieiro: imprensa, ideologia e poder político. São Paulo: Moderna, 1980.

${ }^{60}$ CARVALHO, M.J.M. A Insurreição Praieira ... op.cit. p.25.

${ }^{61}$ Foi nomeado em 25 de dezembro de 1848. JAVARI, Barão, Organizações e Programas ... op.cit. p. 439.

${ }^{62}$ CARVAlHO, M.J.M. A Insurreição Praieira ... op.cit. p.36. Pedro Ivo Velloso da Silveira nasceu no Recife em 1811, filho do coronel Velloso da Silveira. Pedro Ivo seguiu carreira militar e era alinhado politicamente aos liberais. Após o ataque ao Recife continuou combatendo na zona da mata sul da Província. Com o fim da revolta, aceitou a proposta do governo de se entregar em troca da anistia. Para isso, teria de assinar termo comprometendo-se a fixar residência no Pará por dez anos. Como não aceitou foi preso, fugindo em 1851. Embarcou para Portugal, mas adoeceu durante a viagem, morrendo no navio. COSTA, F.A.P. Dicionário Biográfico de Pernambucanos Célebres. Recife: Typographia Universal, 1882 . 
Passada a etapa da repressão militar, o gabinete, a 2 de julho de 1849, nomeou Honório Hermeto Carneiro Leão para ocupar a presidência de Pernambuco, com o objetivo de pacificar a província. As cartas de Honório Hermeto a seus colegas de gabinete ilustram os conflitos que havia dentro do grupo dos conservadores, caso, por exemplo, da correspondência trocada com o Ministro da Justiça ${ }^{63}$. Pedro Ivo, a partir da zona da mata sul de Pernambuco, continuava sua resistência às tropas legalistas. Dadas as dificuldades de derrotá-lo militarmente, este começou a negociar sua rendição e anistia com o governo central, por intermédio do presidente da província Bahia, Francisco Gonçalves Martins ${ }^{64}$. Ou seja, tratava-se de uma negociação não passava por Honório Hermeto, o que, nas palavras de Bruno Estefanes, parecia ao então presidente de Pernambuco uma "falta de lealdade de seus correligionários" "65. Em carta a Eusébio de Queiros datada de 9 de abril de 1850, Honório dizia:

Já pelo vapor Imperador pedi minha demissão; insisti pelo S. Sebastião; e agora de novo me empenho com V. Exa. para que me alivie deste peso.

Sem dúvida muito me ressenti quando fui informado pela carta do Sr. José Bento de 13 do mês passado, que o seu procedimento e negociação com Pedro Ivo e companheiros estava aprovado pelos Srs. ministros, que de tudo tinham sido cientificados, e tudo haviam aprovado. Pouco me importava que os Srs. Gonçalves Martins e José Bento se metessem a dirigir tais negociações e fizessem por si promessas; eu não era agente desses senhores, não estava aqui como Presidente em virtude de suas confianças; e o que eles obravam por si a nada me obrigava: muito porém me devera importar que os Srs. ministros aprovassem essas negociações sem me ouvirem, sem ao menos me instruírem do seu procedimento e vontade a semelhante respeito para a não contrariar. Qualquer Presidente que tivesse brio, encarregado de por em ação os meios de força para reprimir uma revolta, não poderia deixar de ressentir-se se negociação se mandassem encetar e ultimar por outro Presidente, de outra Província, sem ao menos se lhe dar uma palavra, uma idéia do que se mandou fazer.

$\mathrm{O}$ que qualquer Presidente sentiria, eu me achei autorizado a sentir dobradamente; porque além da consideração devida ao posto, esperava que a amizade com que me honram os Srs. ministros me tivesse poupado semelhante desgosto. Foi uma decepção que devera abater o meu amor próprio e orgulho: estou assaz castigado. ${ }^{66}$

Além da questão política, vemos nesta carta um forte ressentimento pessoal com os ministros. Contudo, foi nas cartas ao seu amigo de Coimbra, Paulino José Soares de Souza, Ministro dos Negócios Estrangeiros, que Honório melhor manifestou sua

\footnotetext{
${ }^{63}$ Carta de Honório Hermeto Carneiro Leão a Euzébio de Queiroz, Ministro da Justiça, 9-4-1850. IHGB, Lata 748 Pasta 26: Coleção Leão Teixeira.

${ }^{64}$ ESTEFANES, B.F. Conciliar o Império ... op.cit. p.p. 131-135.

${ }^{65}$ ESTEFANES, B.F. Conciliar o Império ... op.cit. p. 135.

${ }^{66}$ Carta de Honório Hermeto Carneiro Leão a Euzébio de Queiroz, Ministro da Justiça, 9-4-1850. IHGB, Lata 748 Pasta 26: Coleção Leão Teixeira.
} 
discordância política com os colegas. Ainda no início de 1849, o governo imperial havia dissolvido a Câmara dos Deputados. O gabinete pedia a Honório que intercedesse em favor de seus correligionários na eleição. Honório, porém, preferia adotar uma posição de neutralidade, de não intervenção no pleito. Em carta a Paulino de Soares de Souza, datada de 7 de novembro de 1849, dizia o então Presidente de Pernambuco:

Tenho dito a todos que quero conservar-me neutral, e nada fazer pró nem contra candidato algum. $\mathrm{O}$ meu procedimento não satisfaz talvez a ninguém, porém livra-me de dever favores eleitorais, e sobretudo de me deixar entusiasmar em favor de alguma candidatura, e tomar medidas no sentido de a favorecer, no risco talvez de dividir ainda mais o partido, e demais desmoralizar esta Província e talvez o governo. [...] Quando vim para aqui contava com alguma consideração dos Ministros, vou me convencendo de que não valho mais que qualquer Presidente de $1^{\mathrm{a}}$ viagem. ${ }^{67}$

Porém, a questão da tentativa de ingerência do governo nas eleições não era nem nova, nem sequer gerava cisões somente dentro dos gabinetes. Em fins da década de 1840, o próprio Imperador clamava aos ministros uma maior lisura no processo eleitoral, cobrando que cessasse o sistema de nomeações para cargos em troca de apoio aos candidatos do governo. Em 1851, o gabinete, conforme mencionado no início do capítulo, apresentou um pedido de exoneração coletiva ao monarca, sendo Paulino de Soares de Souza um dos signatários do pedido no qual afirma-se que o gabinete não poderia realizar o pensamento do Imperador, que, na opinião dos ministros, necessitaria gastar muitos ministérios para ver sua vontade realizada.

Vossa Majestade Imperial, com aquela alta razão que felizmente possui, sempre foi oposto a este sistema, sempre o embaraçou quando foi possível, concedendo somente, ou quando motivos, que impossível era de livrar, o reclamavam, porque ninguém possui em mais elevado grau do que Vossa Majestade Imperial verdadeiro amor da Pátria e as noções do justo e do honesto. [...] Restabelecer nos seus devidos foros o justo e o honesto. Não fazer das mercês, dos empregos e das recompensas devidas aos servidores do Estado, unicamente moeda eleitoral e meio de uma instável influência de partido. Acalmar os espíritos, reduzir o antagonismo de idéias (e a mui pouco então ficaria reduzido), o antagonismo dos partidos. E, com efeito, Vossa Majestade Imperial não é, não pode, não deve ser homem de partidos. A Divina Providência o fez somente o homem do partido da prosperidade e da grandeza do País e que o chamou a governar. Males inveterados não se curam de pronto, e Vossa Majestade Imperial terá de gastar uns poucos Ministérios antes de ser realizado completamente o seu grandioso pensamento. Para essa nova luta são necessários espíritos mais repousados, é preciso mais calor, mais ânimo, mais vida do que tem os atuais Ministros de Vossa Majestade Imperial. [...] Os abaixo-assinados pensam que

\footnotetext{
${ }^{67}$ Carta de Honório Hermeto Carneiro Leão a Paulino José Soares de Souza, Ministro dos Negócios Estrangeiros, 7-11-1849. IHGB, Lata 748 Pasta 32.
} 
com sua retirada não terá de sofrer a política atualmente seguida, quando Vossa Majestade Imperial entenda em sua sabedoria que a não deve mudar. ${ }^{68}$

Com a saída do gabinete de 11 de maio de 1852, subiu ao poder o ministério de 6 de setembro de 1853, também chamado de ministério da Conciliação, presidido por Honório Hermeto Carneiro Leão, já com o título de Marquês do Paraná. Ascendendo este gabinete ao poder, d. Pedro II, conforme Jeffrey Needell ${ }^{69}$ e Roderick Barman ${ }^{70}$, passou a intervir de forma mais ativa na política ministerial. O Imperador explicitamente ditou o programa do gabinete da Conciliação, ou seja, naquele momento o monarca deixava de simplesmente indicar o Ministério, passando também a impor seu programa aos ministros. Conforme indica Roderick Barman, por meio de um documento denominado Idéias Gerais, o Imperador indicou em 1853 como deveria ser a sua relação com o gabinete $^{71}$. De acordo com este documento, os ministros que usassem o nome do Imperador como justificativa para seus atos seriam demitidos, sendo que o conteúdo das reuniões de despacho do monarca com os ministros deveria ser mantido em segredo.

No entendimento de Barman, d. Pedro considerava que então que o governo deveria não ser partidário, assim como as reformas por ele realizadas, comprometendose, assim, com o progresso material do país, ou seja, o bem público deveria estar acima das paixões partidárias e das facções. Sendo que justamente uma das maiores preocupações do imperador seria a de conferir maior lisura ao processo eleitoral. Nesse sentido, a escolha de Paraná, para Needell, se devia, entre outras coisas, à necessidade que o monarca via de um dirigente saquarema para implementar esta agenda ${ }^{72}$.

\footnotetext{
${ }^{68}$ VIANNA, H. Vultos do Império. São Paulo, Ed. Nacional, 1968, p.p. 152-153. [Grifos meus]

69 NEEDELL, J.D. The Party of Order. The Conservatives, the State, and Slavery in the Brazilian Monarchy, 1831-1871. California: Stanford University Press, 2006.

${ }^{70}$ BARMAN, R.J. Citizen Emperor. Pedro II and the making of Brazil, 1825-91. Stanford, California: Stanford University Press, 1999.

${ }^{71}$ BARMAN, R. Citizen Emperor ... op.cit. p.164.

${ }^{72}$ Segundo Tamis Parron, a partir do livro de Roderick Barman, Citizen Emperor, Needell recuperou a tradição historiográfica brasileira sobre a crescente intervenção de d. Pedro II, em que se destacam Raymundo Faoro e Sérgio Buarque de Holanda. A marca do gabinete, nas palavras de Jeffrey Needell é de que se tratava de um gabinete conservador, mas não saquarema. NEEDELL, J.D. The Party of Order ... op.cit. p.p.172-175. PARRON, T.P. A Política da Escravidão no Império do Brasil, 1826-1865. Dissertação de Mestrado apresentada ao Programa de Pós-Graduação em História Social, FFLCH/USP. São Paulo, 2009. p. 216. Segundo Roderick Barman, havia uma incapacidade dos liberais de implementarem os melhoramentos almejados pelo Imperador. BARMAN, R. Citizen Emperor ... op.cit.
} 
Em razão desta nova postura de Pedro II em relação aos gabinetes, os chamados saquaremas se colocaram contrariamente à política da conciliação. Ainda em 1854, o gabinete, a partir de projeto apresentado por Nabuco de Araújo buscou reformar um dos principais pilares da política saquarema: a Lei de 3 de dezembro de 1841. Ainda que não caiba aqui uma análise dos pormenores do projeto, é necessário destacar alguns pontos. No que diz respeito à justiça criminal, ficaria o governo autorizado a rever e alterar o Processo da qualificação dos jurados, além de dobrar o rendimento anual exigido para ser jurado ${ }^{73}$. O projeto também retirava da Polícia a atribuição de formar a culpa, deixando-a a cargo do Juiz Municipal e do Promotor Público. Além disto, retirava o Corpo de Jurados dos distritos, concentrando-os na cabeça das comarcas. Apesar de seu projeto não ter nenhum elemento de retorno à justiça cidadã do Código de 1832, alterava muitas disposições da Lei de 3 de dezembro. Com o objetivo de separar polícia e justiça, retirava poder dos delegados, subdelegados e chefes de polícia. Ou seja, grande parte dos cargos criados na reforma de 1841 ficariam esvaziados de poder, portanto, não seriam mais uma oferta vantajosa para obter apoio aos candidatos do governo. Ainda segundo o projeto, os crimes afiançáveis seriam julgados pelos Juízes de Direito na cabeça das comarcas e os crimes inafiançáveis pelos Juízes Municipais nas cabeças dos termos. Com isso, concentrava a justiça criminal nas cabeças dos termos e comarcas. Isso, certamente era um para ter acesso às clientelas locais, pois os delegados e sub-delegados eram justamente agentes do governo nas localidades. Desprovidos de poder efetivo, esses cargos não eram atrativos aos potenciais apoiadores do governo.

O já visconde do Uruguai, que se opôs tenazmente à medida, considerava que a separação proposta pelo projeto produziria diversos males. Para ele, não se poderia tirar das autoridades policiais a atribuição de formar a culpa, pois entendia que sua ação não era prejudicial, uma vez que suas decisões precisavam ser confirmadas pelos Juízes

p. 123. O debate historiográfico sobre a conciliação é bastante amplo. No entanto, vale dizer que a interpretação a respeito de uma maior intervenção de d. Pedro II na política dos gabinetes não é consensual. Ilmar Rohloff de Mattos e José Murilo de Carvalho, por exemplo, consideram que a conciliação representa o triunfo dos conservadores. MATTOS, I.R. O Tempo Saquarema. São Paulo: Hucitec, 1987, CARVALHO, J.M. A Construção da Ordem, Rio de Janeiro: Civilização Brasileira, 2003 e CARVALHO, J.M. Teatro de Sombras. Rio de Janeiro: Civilização Brasileira, 2003.

${ }^{73}$ IHGB: Coleção Nabuco. 1181: REFORMA JUDICIÁRIA: Provas Tipográficas do Projeto de Reforma Judiciária com detalhados pareceres de diversas personalidades. DL 389.2 
Municipais, com recurso aos Juízes de Direito. "Pronuncio-me, portanto, contra o excessivo retraimento da autoridade que encontro no projeto". O retraimento das autoridades policiais possuía, entre outras coisas, uma implicação política séria, que era o fato de o gabinete não possuir acesso direto às clientelas locais para poder negociar apoio. Para Uruguai era indispensável localizar razoavelmente a autoridade, possuindo ela meio de se fazer sentir nas localidades, "atenta à dispersão da população, e à dificuldade e às vezes falta absoluta de comunicação na maior parte do território do Império". O projeto de Nabuco, na visão de Uruguai ignorava justamente a dispersão territorial do país, impedindo que a autoridade do governo chegasse nas localidades.

Assim, Uruguai concluía que:

Não julgo perfeita a Lei de 3 de dezembro, mas está em perfeita harmonia com os princípios abstratos da ciência. Está, porém em mais harmonia com as nossas peculiares circunstâncias. Um edifício construído em um terreno desigual, cheio de altos e baixos, não pode apresentar a simetria e regularidade, e ter a beleza d'outro levantado em terreno igual e plano.

Melhore-a, aperfeiçoe-a, mas não suprime o governo de uma arma fortíssima que lhe há de ser precisa ainda, porque a ordem pública não está ainda consolidada, de modo que não possa mais vir a ser levianamente perturbada.

[...] Porém não ser ainda chegada a época de desarmar-se o governo, se é que algum governo deve desarmar-se e muito principalmente quando a opinião que reclamava esse desarmamento não o reclama mais, não destrua a Lei de 3 de dezembro, antes a conserve, ache-a boa, e sirva-se dela. ${ }^{74}$

A despeito do apoio do gabinete e do monarca, os saquaremas comandaram uma forte oposição ao projeto de reforma judiciária que, com o auxílio dos fazendeiros de Vassouras, fez com que ela não fosse aprovada pelo Senado. Contudo, se o gabinete não foi bem sucedido em sua tentativa de reformar a Lei de 3 de dezembro, conseguiu lograr êxito ao aprovar a reforma eleitoral em 1855. Honório fez da aprovação da lei questão de gabinete, jogando todo o seu peso político para sua aprovação. A reforma eleitoral estabeleceu não só a eleição por círculos eleitorais de um deputado, como também elencou uma série de incompatibilidades (tornando certas autoridades inelegíveis no círculo de sua jurisdição) ${ }^{75}$. A reforma desagradou profundamente aos

\footnotetext{
${ }^{74}$ Opinião do Senador Soares de Souza in: IHGB: Coleção Nabuco. 1181: REFORMA JUDICIÁRIA: Provas Tipográficas do Projeto de Reforma Judiciária com detalhados pareceres de diversas personalidades. DL 389.2. Grifos Meus.

75 Segundo Monica Duarte Dantas, a chamada Lei dos Círculos (Lei no 842 de 1 de setembro de 1855) instituiu o voto distrital no Império. As províncias foram divididas em distritos, "círculos" eleitorais, de
} 
saquaremas. Uruguai por essa época encontrava-se na Europa. A oposição saquarema ao projeto no Senado foi comandada por Euzébio de Queiros. Em discurso de 7 de junho de 1855 se posicionou contrariamente às incompatibilidades, afirmando que os magistrados na política prestavam bons serviços ao país. Cita como exemplo o Visconde do Uruguai que fora Juiz na Corte e que, em sua visão, prestara grandes serviços ao país. Contudo, o que estava em questão na votação das incompatibilidades era que com elas, ficaria mais difícil para o governo eleger os seus candidatos, pois, a maior parte dos cargos que Lei de 3 de dezembro criara ou modificara eram cargos de magistratura. Os aliados do governo eram justamente acomodados nesses cargos. Contudo, com as incompatibilidades, não poderiam se eleger nos locais onde exerciam jurisdição e, tinham a possibilidade de utilizar o aparato do Estado para angariar apoios. Quanto ao voto distrital, Euzébio considerava que isso enfraquecia as lideranças partidárias, ligadas, a seu ver, por interesses comuns, e fortalecia lideranças de segunda categoria (leia-se lideranças locais), sem qualquer conexão ou senso de ação comum em pról de Província ${ }^{76}$.

Se o gabinete presidido por Honório iria ou não tentar recolocar a reforma da lei de 3 de dezembero, depois de eleita a nova câmara conforma as regras de 1855, isso é impossível de saber, uma vez que o presidente, homem forte do gabinete, faleceu em setembro de 1856. Com a morte de Paraná. D. Pedro II escolheu para substitui-lo Luis Alves de Lima e Silva (então marquês e futuro duque de Caxias).

Antes ainda da aprovação da Lei dos círculos, e após o fracasso da reforma judiciária, Uruguai já escrevera de Paris para Eusébio afirmando que não via ninguém além dele ou de Rodrigues Torres em condições de substituir Paraná caso ele caísse ${ }^{77}$. No período de Caxias à frente do gabinete, ocorreu a primeira eleição feita sob o novo sistema. Mesmo fora do gabinete, saquaremas como Uruguai se esforçaram por eleger seus candidatos. Uruguai lançou seu filho candidato à deputado geral. Entretanto, a

acordo com o número de deputados que elas elegiam. Cada círculo elegia um deputado. DANTAS, Monica Duarte, "Constituição, poderes e cidadania na formação do Estado-nacional brasileiro", Rumos da Cidadania, Instituto Prometeus, p. 19. Cópia cedida pela autora.

${ }^{76}$ NEEDELL, J.D. The Party of Order ... op.cit. p. 192.

${ }^{77}$ NEEDELL, J.D. The Party of Order ... op. cit. p. 183. 
despeito das dificuldades (antes ainda de morrer, Paraná havia indicado Francisco Otaviano como candidato pelo círculo de Cabo Frio), Uruguai conseguiu elegê-lo ${ }^{78}$

O gabinete Caxias, contudo, não duraria muito, caindo já em 4 de maio de 1857. Respondendo ao vaticínio feito por Uruguai anos antes, o Imperador chamou-o para organizar o novo gabinete; a ele, um saquarema "emperrado".

Dada a amizade de Uruguai com Paraná, ele nunca se manifestara publicamente, até aquele momento, a respeito da Conciliação, o que certamente o habilitava para ser escolhido para presidir o Conselho de Ministros. Além disso, caso se considere a opinião de vários autores a respeito de tal política, como sendo fruto de uma imposição do monarca, talvez Uruguai não desejasse se indispor com d. Pedro II. O fato é que em 30 de abril de 1857, Uruguai foi chamado ao Paço para se reunir com o Imperador e foi nessa ocasião que lhe foi feito o convite. O que se sabe é que Uruguai recusou o convite, sendo nomeado em seu lugar o Marquês de Olinda, em 4 de maio de 1857. José Antonio Soares de Souza afirma que em uma notícia publicada no Anuário da Revista dos Dois Mundos o tema da recusa foi abordado, atribuindo-a à discordância de Uruguai em relação à política da Conciliação. Contudo, foi no dia 28 de maio de 1858 no Senado que Uruguai exprimiu publicamente o seu pensamento sobre essa política. Entre outras coisas, alegou que a conciliação não poderia ser uma política imposta pelo governo, pois:

A conciliação é uma conseqüência do estado e atuais circunstâncias da sociedade, é uma necessidade da nossa época. Quem foi plantar a bandeira da concórdia entre os antigos partidos moderado e exaltado? Houve algum ministério que se lembrasse de se apresentar entre eles, conciliando-os, quando eram inconciliáveis, quando as suas paixões estavam na sua maior efervescência, quando seus interesses eram mais encontrados e vivazes? Se algum ministério o tivesse feito então, teria perdido o seu tempo e a sua força, e teria sido levado de rojo por ambos os partidos. E onde estão eles hoje? Acalmaram-se, modificaram-se com o tempo, transformaram-se, desapareceram, e são hoje recordações históricas. Qual foi o ministério que os conciliou ? $^{79}$

\footnotetext{
${ }^{78}$ Ver: Biblioteca Nacional, Coleção Tobias Monteiro: 2.323: URUGUAI: Visconde do: Carta a seu filho falando sobre questões eleitorais, da morte do marquês do Paraná e da crítica situação política em que se encontra o ministério, além de tratar de assuntos pessoais. Paris/RJ 14/07/1856-13/01/1857. 7 docs. 22p. 63, 04, 002 n $^{\mathbf{o}} 110$.

${ }^{79}$ Anais do Senado, Sessão de 28 de maio de 1858, p.214.
} 
Esta fala de Uruguai possui um duplo sentido. No discurso está dizendo que a Concialição não fora obra do ministério, e sim uma consequiência do atual estado da sociedade. Porém, pode-se questionar se, ao afirmar isto, ele também não estaria qurendo dizer que não se tratava de obra daquele ministério, por já ter sido determinada antes que ele ascendesse ao poder. Ainda no mesmo discurso, afirmava que havia sempre interesses nas províncias para serem acomodados em troca de apoio, inclusive, para "conciliar".

Há porém um grande inconveniente no modo pelo qual o governo apregoa essa tendência como política sua. Substitui a sua ação à do tempo e das circunstâncias,e toma a si a responsabilidade de toda aquela conciliação que não se pode fazer. $O$ governo é que é o conciliador, muitos esperam dele que os concilie e não faltam os que querem alguma compensação para se conciliarem, e para isso é preciso que permaneçam nas suas antigas posições.

[...] Fazem-se concessões, dão-se empregos para conciliar. Outros esperam o mesmo, e não se conciliam, e esse modo de conciliar. Outros esperam o mesmo, e não se conciliam, e esse modo de conciliação, se concilia a uns, desconcilia outros e produz desmoralização.

Há partidos discriminados em uma província. Vá um presidente para os conciliar, e este muitas vezes desconcilia para conciliar, isto é, desmonta, faz reações que provocam outras para conciliar.

[..] É escolhido um homem que pertenceu a um dos antigos partidos, teoricamente moderado e conciliador. Dificilmente deixará de pender a balança para o lado daqueles aos quais naturalmente tem mais afeições. As afeições do nosso coração e as prevenções do nosso espírito dificilmente deixam de prejudicar os nossos juízos. Faço aos cidadãos nomeados pelo governo presidentes para certas províncias a justiça de crer que, quando saem do Rio de Janeiro, vão com intenções moderadas e conciliadoras. Chegam à província com a conciliadora intenção de equilibrar as forças e posições dos partidos como se isso pudesse conciliar, porém nada mais natural do que não lhes deixar a prevenção ver bem o fiel da balança; e qual o resultado? Demitem para equilibrar. Essas demissões trazem reação Essa reação, luta e novas demissões: e daí há pouco tem está completamente posta de parte a conciliação. Assim, para conciliar desconcilia-se. ${ }^{80}$

Ou seja, com esta fala, Uruguai buscava mostra que a política da Conciliação não acabara com o sistema que o Imperador havia decidido dar fim. Se retornarmos ao pedido de exoneração coletiva, vemos que era justamente disto que o monarca reclamava aos seus ministros. Não desejava o falseamento das eleições, que era, entre outros expedientes, obtido com a oferta de cargos em troca de apoio. Quando passou a interferir na política dos gabinetes, foi, aparentemente para modificar este estado de

\footnotetext{
${ }^{80}$ Anais do Senado, Sessão de 28 de maio de 1858, p.214.
} 
coisas. Para Uruguai, a principal tarefa do gabinete de 1853 teria sido justamente a de levar a cabo este desejo do Imperador. Não é por outro motivo que em sua primeira sessão legislativa procurou reformar a Lei de 3 de dezembro de 1841 e, apesar dessa primeira derrota, aprovou no ano seguinte a chamada Lei dos Círculos. Contudo, a política de moderação levada a cabo pelos gabinetes e a reforma eleitoral não haviam acabado com o sistema que tanto desagradava ao monarca. A conciliação colocava, pelo que se depreende do discurso do visconde, o seguinte problema: para conciliar os diferentes partidos era necessário haver cargos para acomodar lideranças de ambos, o que, no fim, somente agravava aquilo que se pretendia modificar.

\section{2 - O REI REINA E GOVERNA}

O gabinete Olinda de 1858, apesar de ser presidido por um conservador, sofreu forte oposição por parte dos saquaremas. Com a reforma da lei bancária, que colocava grande quantidade de moeda em circulação, o ministro da Fazenda, Bernardo de Souza Franco, teve de enfrentar duros ataques dos saquaremas no Senado (Itaboraí, Eusébio de Queiroz e Uruguai). Este ataque dos saquaremas não só derrubou a lei bancária, como também o próprio gabinete ${ }^{81}$. Caindo o gabinete, o Imperador mais uma vez chamou o visconde do Uruguai para presidir o Conselho de Ministros. Mais uma vez houve a recusa.

Em sua atuação política a partir da Conciliação, Uruguai foi ativo como senador e conselheiro de Estado. Porém, antes de mais, é necessário retomar brevemente a própria história do Conselho de Estado desde a década de 1820. O primeiro Conselho foi criado em fevereiro de 1822 com o nome de Conselho dos Procuradores Gerais das Províncias do Brasil. Teve uma curta duração, sendo extinto em outubro de 1823 pela Assembléia Constituinte. Uma vez dissolvida a Assembléia, o Conselho foi recriado, já com o nome de Conselho de Estado, por dom Pedro I; composto então por dez membros, além dos ministros de Estado. Pouco depois, na Constituição de 1824, determinava-se que ele seria formado por dez membros vitalícios nomeados pelo

${ }^{81}$ GRAHAM, R. O Brasil de Meados do Século XIX à Guerra do Paraguai in: Bethell, L. (org.), História da América Latina, Da Independência a 1870. São Paulo: EDUSP \& Imprensa Oficial, 2001, p. 811 
Imperador, não estando os ministros compreendidos entre os conselheiros, salvo se fossem para isso nomeados; estipulava-se também que, para o posto de conselheiro, era exigida a mesma que renda que deveriam comprovar os postulantes ao Senado ${ }^{82}$. Segundo a carta, em seu artigo 142, a audiência do Conselho era obrigatória em todos os casos em que o Imperador fosse utilizar o Poder Moderador.

Em 1834, em conformidade com o art. 32 do Ato Adicional, o Conselho de Estado foi suprimido da Constituição. Todavia, pouco depois da maioridade de d. Pedro II, o Conselho de Estado foi restabelecido pela Lei $n^{\circ} 234$ de 23 de novembro de 1841. Contudo, uma vez que sua supressão fora feita por reforma constitucional, mesmo que recriado em 1841, ele não mais poderia ser de audiência obrigatória, sendo sua consulta somente facultativa. Esta, porém, não era a única diferença em relação ao Conselho de 1824, sua organização interna também foi profundamente modificiada.

Passou a ser composto, então, por 12 membros ordinários e 12 membros extraordinários, cuja função era substituir os ordinários quando não pudessem exercer suas funções, principalmente por estarem em gabinetes; cuja nomeação continuava a cargo do Imperador. O novo Conselho de Estado teve sua atuação regulamentada pelo Regulamento $\mathrm{n}^{\mathrm{o}} 124$ de 5 de fevereiro de $1842^{83}$. Segundo esse regulamento, o Conselho de Estado deveria funcionar em quatro Seções: Justiça e Estrangeiros, Império, Guerra e Marinha, e Fazenda. Cada seção era composta por três conselheiros e suas reuniões presididas pelo ministro da pasta correspondente, que não votava, devendo apenas presidir a reunião. O Conselho de Estado Pleno, órgão da alta cúpula política do Império, consistia na reunião de todas as seções, sob a presidência do Imperador. Segundo o Regulamento o Imperador ao apreciar o parecer de alguma seção poderia provocar o Conselho de Estado Pleno antes de tomar sua decisão final. Ademais, o Imperador também poderia convocar o Conselho Pleno para a discussão de alguma questão política urgente. Já as Seções deveriam se reunir para tratar de assuntos mediante requisição feita a partir de Avisos Ministeriais; designava-se então um relator e o assunto sobre o qual a Seção deveria dar seu parecer. Ao relator cabia emitir o parecer, que deveria ser assinado pelos outros conselheiros, sendo que aqueles que

\footnotetext{
${ }^{82}$ RODRIGUES, José Honório. O Conselho de Estado. Brasília, Senado Federal, 1978, Volume 2, p.p. 1-22. Constituição Política do Império do Brasil, Título 5º Capítulo 7, Arts. 137-144.

${ }^{83}$ Regimento Provisório do Conselho de Estado. Regulamento no 124 de 5 de fevereiro de 1842.
} 
discordassem deveriam apresentar voto em separado. Uma vez feito o parecer, ele era apresentado ao Imperador que, ou bem podia emitir uma Resolução Imperial a partir dele (que seguia, ou não, a opinião do relator ou o voto em separado de qualquer um dos membros, ou mesmo dava à questão a interpretação que bem entendesse); ou então remetia o parecer ao Conselho de Estado Pleno para depois tomar sua decisão. Algo importante de se apontar é que no caso das Seções de Guerra e Marinha e de Justiça e Estrangeiros, elas respondiam a questões de dois ministérios. Assim, por exemplo, no caso da Seção de Justiça e Estrangeiros, ao ser provocada por Aviso do Ministério da Justiça, apresentava-se como Seção de Justiça; já ao ser provocada por Aviso do Ministério dos Negócios Estrangeiros, apresentava-se como Seção dos Negócios Estrangeiros $^{84}$.

Em 1858, em discussão do Conselho de Estado Pleno ${ }^{85}$ Uruguai tratou de uma questão que iria desenvolver em profundidade no Ensaio, a não necessidade de referenda nos atos do Poder Moderador por parte dos ministros.

Conforme a Constituição de 1824, em seu Capítulo 1 , do Título $5^{\circ}$, o Poder Moderador foi definido como uma delegação da nação, sendo privativo do monarca e a “chave de toda a organização política". Além de chefe desse poder e o único a exercê-

\footnotetext{
${ }^{84}$ José Reinaldo de Lima Lopes destaca que além de órgão da alta política imperial, o Conselho de Estado também desempenhava um importante papel de intérprete da lei, em detrimento do Superior Tribunal de Justiça. A Constituição de 1824 em seu Título $6^{\circ}$, Capítulo Único definiu as atribuições do Poder Judiciário. O teor do texto mostra como se tratava de um aparato ainda para ser montado. Previa a criação de Relações e previa a criação do Supremo Tribunal de Justiça (STJ). No dia 18 de setembro de 1828 foi promulgada a Lei de Constituição e Composição do Supremo Tribunal de Justiça. O Artigo $5^{\circ}$ da Lei de 18 de setembro estabelecia as funções do Tribunal. Por ele, competia conceder ou denegar revistas, conhecer dos delitos e erros de ofício que cometidos por seus ministros, das relações, dos empregados no corpo diplomático e dos presidentes das províncias. Caso a revista fosse concedida, os autos seriam remetidos ex-offício a uma Relação designada pelo Tribunal. Em nenhum caso as partes seriam novamente ouvidas. Sendo proferida a sentença da revista, os autos deveriam ser remetidos exofício pelo presidente do tribunal revisor ao juízo em que fora proferida a sentença recorrida, fazendo oficialmente ao supremo tribunal participação da remessa. Como aponta Lopes, o funcionamento do Supremo Tribunal de Justiça significava que a última instância em qualquer processo seria a Relação, uma vez que tudo o que o tribunal fazia era conceder ou não a revista, enviando-a para ser julgada por uma Relação. Segundo o autor, isto se deve principalmente ao fato de a Constituição prever somente dois graus de jurisdição. Assim, caso o Supremo Tribunal se envolvesse nos casos, se tornaria terceira instância, algo não previsto pela Constituição. LOPES, J.R.L.O Oráculo de Delfos. O Conselho de Estado no Brasil-Império. São Paulo: Saraiva \& Fundação Getúlio Vargas, 2010, p.94. Ver também: LOPES,J.R.L, O Supremo Tribunal de Justiça no Apogeu do Império (1840-1871). in: LOPES,J.R.L (org.), O Supremo Tribunal de Justiça do Império (1828-1889). São Paulo: Editora Saraiva \& Fundação Getúlio Vargas, 2010.

${ }^{85}$ RODRIGUES, J.H. Atas do Conselho de Estado. Brasília, Senado Federal, 1978. Volume 5. Ata de 16 de novembro de 1858 .
} 
lo, sua pessoa era inviolável e sagrada (art.99), portanto, não estava sujeito à qualquer responsabilidade legal pelos seus atos. O art. 101 estabelecia as atribuições do Poder Moderador que eram: nomear os senadores a partir das listas tríplices, convocar a Assembléia Geral extraordinariamente no intervalo das sessões; sancionar os decretos da Assembléia Geral; prorrogar ou adiar a Assembléia geral e, segundo a Constituição, poderia dissolver a Câmara dos Deputados quando o exigisse "a salvação do Estado"; nomear os ministros, suspender magistrados, perdoar ou minorar pena impostas por sentenças, e conceder anistia ${ }^{86}$.

O Imperador, contudo, não era somente o titular do Moderador, sendo também o chefe do Poder Executivo, que exercia por meio de seus ministros. Devido ao art. 102, os Atos do Poder Executivo possuíam necessariamente a referenda ministerial, uma vez que era por meio dos ministros que esse poder era exercido ${ }^{87}$. No caso do Poder Moderador, contudo, não havia qualquer menção na Constituição sobre essa questão, a não ser que ele era privativo do Imperador (pessoa que, por sinal, conforme o art. 99 da carta, era inviolável e sagrada).

Durante a Regência, houve a necessidade de regular o uso do Poder Moderador por parte dos Regentes. A Lei de 14 de junho de 1831 declarou em seu art. 10 que a Regência exerceria todas as atribuições do Poder Executivo e do Poder Moderador, com a referenda do ministro competente. $\mathrm{O}$ art. 19 limitou também as atribuições do Poder Moderador que a Regência poderia exercer. Vedou, entre outras coisas: a dissolução da Câmara dos Deputados; a concesão de anistia em casos urgentes; o perdão das penas de ministros e conselheiros de Estado, salvo em casos de pena de morte; e, finalmente, a concessão de títulos, ordens militares e distinções. Devido ao fato de ter havido referenda nos atos do Poder Moderador na Regência, essa prática persistiu após a maioridade de Dom Pedro II, o que gerou, conforme se verá, diversas discussões, como, por exemplo, a já mencionada de 1858.

\footnotetext{
86 Constituição Política do Império do Brasil, Título 5º, Capítulo 1, Art.s 98, 99 e 101.in: in BONAVIDES, Paulo \& Amaral, Roberto, Textos políticos da história do Brasil, Brasília, Senado Federal, 2002, vol. VIII, pp. 140-165.

${ }^{87}$ Quanto ao Poder Executivo, foi criado por Decreto $\mathrm{n}^{\circ} 523$ de 20 de julho de 1847 o cargo de Presidente do Conselho de Ministros, que, nomeado pelo Imperador, ficava encarregado de chefiar o gabinete e nomear dos demais ministros. Ver: JAVARI, Barão, Organizações ...op.cit. p.p. 99-100.
} 
Essa discussão no Conselho de Estado Pleno teve sua origem em um parecer emitido pela Seção do Império, que discutia a legitimidade da eleição senatorial. O debate girava em torno da questão de a quem competia a indicação de senadores e a quem competia a verificação de seus poderes. A Seção do Império entendera que o Poder Moderador, que pela Constituição possuía a atribuição de indicar os senadores a partir de lista tríplice, tinha o direito de anular eleições caso a referida lista fosse ilegítima.

A discussão travada no Conselho Pleno mostra como a questão da referenda estava presente até nesta circunstância da escolha dos senadores, que mesmo durante a Regência não fora um ponto polêmico, podendo os Regentes nomear livremente os senadores a partir das listas tríplices. Para o visconde de Sapucaí, relator do parecer:

O Poder Moderador não é máquina; é uma inteligência que obra, e deve entrar, por intermédio dos Ministros, no exame das eleições para cumprimento do dever, que a Constituição lhe impõe, de escolher somente os que estiverem nas circunstâncias por ela determinadas. Nem se diga que este direito é exclusivo do Senado por virtude do Artigo 21 da Constituição, que confere a cada uma das Câmaras a verificação dos poderes de seus membros, que se fará na forma de seus regimentos. A Seção reconhece no Senado esse direito, mas não exclusivamente, posto que também não seja expressa na Constituição. ${ }^{88}$

Já Uruguai, ao se colocar no debate, dizia entender que ao Poder Moderador competia a indicação e ao Senado a verificação de Poderes, ou seja, conferir se a lista era legítima ou não. Menos importante neste caso, contudo, para os fins da presente dissertação, é a questão da eleição propriamente dita, mas sim o fato de que Paulino, na construção de sua argumentação, ainda que não considerasse atribuição do Moderador conferir a legitimidade da lista, defendia, ao justificar tal posição, a não-referenda ministerial.

A Constituição deu ao Poder Moderador atribuições, que pela sua natureza não tem outra responsabilidade, senão a grande responsabilidade moral perante a Nação, porque a responsabilidade legal em matéria política tem limites que é impossível ultrapassar. Se fosse indispensável a referenda, sê-lo-ia para todos os atos do Poder Moderador, porque não há disposição na Constituição, que possa autorizar uma exceção. Seria portanto indispensável a referenda para a nomeação e demissão de Ministros.É verdade que têm sido referendados os atos do Poder Moderador, mas quod abundata non nocet, e esse fato, por si só, não prova que a referenda seja indispensável.

Assim, para o caso em questão diz:

\footnotetext{
${ }^{88}$ RODRIGUES, J.H. op.cit. p.p. $46-47$
} 
$[\ldots]$

O exame e decisão de questões miúdas eleitorais, e essencialmente locais, a aplicação das leis a fatos especiais, não é próprio da larga e elevada missão do Poder Moderador. Há o Tribunal competente, o da verificação dos poderes, o Senado. O exame, e a decisão sobre a validade de uma eleição é um verdadeiro julgamento. Não deve basearse em uma apreciação meramente política, e posto seja uma sentença de natureza política, é contudo a aplicação das leis aos fatos, conforme os documentos e provas. ${ }^{89}$

Esta última parte da fala de Uruguai é significativa, pois afirma que o Poder Moderador, ou seja, o Imperador não deveria entrar no exame de questões miúdas eleitorais como a verificação dos poderes; sendo, no caso, o Senado o tribunal competente para verificar os poderes de seus membros. A preocupação de Uruguai com a interferência do Imperador no Poder Executivo, conforme visto no início do capítulo, remonta ao pedido de exoneração coletiva apresentado pelo gabinete em 1851 .

A questão da referenda, que apareceu nessa discussão do Conselho de Estado Pleno, remontava, contudo, à publicação, em 1857, do livro de José Antonio Pimenta Bueno (futuro Marquês de São Vicente), Direito Público Brasileiro e Análise da Constituição do Império. Nessa obra, Pimenta Bueno abordou questões que foram retomadas por Zacarias de Góes e Vasconcelos em 1860, em seu livro Da Natureza e dos Limites do Poder Moderador, e por Uruguai no Ensaio Sobre o Direito Administrativo em 1862. Após a publicação do Ensaio, Zacarias reeditou e ampliou sua obra para combater as opiniões de Uruguai no tocante ao Poder Moderador. O debate entre esses autores foi objeto de discussão por parte de Cecília Helena de Salles Oliveira $^{90}$ e Silvana Mota Barbosa ${ }^{91}$. Na discussão desse capítulo, dentro da proposta

\footnotetext{
${ }^{89}$ RODRIGUES, J.H. op.cit p. 52-53

${ }^{90}$ Cecília Helena de Salles Oliveira parte do princípio de tomar as obras desses autores dentro de seu devido contexto de elaboração, ou seja, a década de 1860, quando já havia experiência concreta de praticamente quatro décadas da existência do Poder Moderador. A autora chama atenção para o fato de essas obras em diversos trabalhos serem tomadas fora de seu contexto de escrita. A origem do debate sobre o tema na década de 1860 estaria na publicação do livro de Pimenta Bueno em 1857. Em sua visão, muitos dos argumentos expressos por esses autores, além de representarem interesses de partidos e grupos específicos, também retratavam diferentes projetos de Estado gestados ao longo da experiência que acumularam na gestão dos negócios do Estado. OLIVEIRA, C.H.S. Contribuição ao Estudo do Poder Moderador in: OLIVEIRA, C.H.S. BITTENCOURT, V.L.N. COSTA, V.P. Soberania e Conflito. São Paulo, Hucitec e Fapesp, 2010, p.p. 185-235. Ver também: OLIVEIRA, C.H.S. O Poder Moderador no segundo reinado - mediações entre fontes e historiografia. in: Justiça e História, Vol.3, no 5 . Porto Alegre: Tribunal de Justiça do Rio Grande do Sul, 2003, p.p. 141-160.

${ }^{91}$ Silvana Mota Barbosa retoma as origens da idéia de Poder Moderador, assim como sua recepção no Brasil e o modo como ele se constituiu em Portugal. Ao tratar do Brasil, a autora se debruça sobre o debate acerca do Poder Moderador na década de 1860, desde os debates na imprensa, até as obras de
} 
elaborada, são de grande relevância as perspectivas apontadas por Oliveira e Barbosa, no que diz respeito à contextualização das obras no debate e as relações disso com o Poder Executivo.

Para se entender então o posicionamento de Uruguai a respeito do Moderador, e sua defesa de que não necessitava de referendo por parte dos ministros (conforme explicou não só no Ensaio, mas também em seus vários pareceres e opiniões no Conselho de Estado), é necessário retomar o debate da época, os três autores que destacamos.

Em seu livro, Direito Público e Análise da Constituição do Império, Pimenta Bueno faz uma análise minuciosa da Constituição de 1824, buscando definir o espaço de atuação de cada um dos poderes de Estado. O referido autor ponderava que em razão de o art. 98 da Constituição declarar que o Poder Moderador era delegado pela nação privativamente ao monarca, ele constituía uma garantia pra a nação. Dada a sua natureza, ele era a mais elevada inspeção que a nação possuía sobre os demais poderes. Assim, entendia que o Moderador era distinto do Poder Executivo, não podendo ser exercido pela massa, necessitando ser delegado ${ }^{92}$. O autor considerava um erro o fato das atribuições do Moderador (conforme a carta de 1824) estarem,na maioria das monarquias constitucionais, confundidas com as do Poder Executivo. Para Pimenta Bueno, o Poder Moderador deveria ser confiado somente ao imperante, e somente a ele, excluindo-se disso os ministros ${ }^{93}$. Essa idéia, contudo, gerava diversas controvérsias, pois como a Constituição declarava a pessoa do monarca inviolável e sagrada, e portanto não sujeito a qualquer responsabilidade legal pelos seus atos, não havia ninguém que se responsabilizasse perante a nação pelos atos desse poder. Quanto à esse caráter inviolável e sagrado que a Constituição conferia ao monarca, Pimenta Bueno considerava que não havia meio termo possível, pois em sua visão "a qualidade de

direito, onde destacam-se os livros de Uruguai, Pimenta Bueno e Zacarias. Em sua visão, é necessário levar em consideração que esse debate não evolvia somente o Poder Moderador ou o Imperador. Estava também envolvido o Poder Executivo e seus agentes, ou seja, os ministros. BARBOSA, S.M. A sphinge monárquica: o poder Moderador e a política imperial. Tese de doutoramento. Campinas: Unicamp, 2001, p.p. 392-393.

92 PIMENTA BUENO, J. A. Direito Público Brasileiro e Análise da Constituição do Império. In: KUGELMAS, E. Marquês de São Vicente. São Paulo: Editora 34, 2002, p. 280.'

${ }^{93}$ PIMENTA BUENO, J.A. Direito Público ... op.cit. p.281. 
imperante é inseparável da pessoa que a exerce; a inviolabilidade ou há de ser geral, ou inútil"94.

O futuro marquês de São Vicente também se dedicou a tratar das atribuições do Poder Moderador, conforme estabelecidas no art. 101 da Constituição. Quanto à prerrogativa de sancionar ou denegar as leis e resoluções da Assembléia Geral, Pimenta Bueno considerava esta atribuição inerente à monarquia constitucional. Pela sua natureza, opinava que só ao Moderador poderia pertencer tal atribuição, pois era o que garantia à Coroa o direito de mover os perigos de uma medida nociva, sem ter de arcar com o ônus político de uma dissolução ${ }^{95}$. Quanto à possibilidade de dissolução, afirmava que a Câmara dos Deputados era o baluarte das liberdades públicas, mas que justamente a história política já havia demonstrado os perigos que poderiam vir da Câmara. Assim, a possibilidade dissolvê-la era uma prerrogativa indispensável do Poder Moderador, uma vez que a Câmara, caso fosse animada por paixões e excessos, traria como conseqüência diversos males ao país; ou seja, era necessário haver freios à possibilidade de "despotismo ou intolerância" por parte da Câmara temporária. Afinal, ponderava "Estará sempre a razão de parte dela [da Câmara], e nunca da parte do ministério, para que seja sempre este quem deva retirar-se?"96 Entretanto, também considerava que a dissolução era uma medida grave, só devendo ter lugar em casos extremos. Além disso, pontificava que a Câmara dos Deputados não era o único órgão político sujeito a cometer abusos, uma vez que os ministros também podiam fazê-lo; em ambos os casos o Imperador deveria consultar o Conselho de Estado a respeito do melhor encaminhamento da questão, ou seja, se deveria dissolver a Câmara ou substituir o gabinete ${ }^{97}$. Pimenta Bueno considerava, finalmente, que a prerrogativa de obrar qualquer um desses encaminhamentos, pela sua natureza, só poderia estar ligada ao Poder Moderador.

Predomine ou não uma facção, intente ou não uma política fatal, desde que se dá um desacordo inconciliável entre a Câmara dos Deputados e o ministério, o Poder Moderador é, pela natureza das coisas, chamado a examinar, e em sua consciência apreciar onde entende estar a razão. Se de parte da Câmara cumpre dissolver o ministério; se de parte deste cumpre dissolver aquela, e destarte consultar a nação, para

\footnotetext{
${ }^{94}$ PIMENTA BUENO, J.A. Direito Público ... op.cit. p. 282.

${ }^{95}$ PIMENTA BUENO, J. A. Direito Público ... op.cit. p. 285.

${ }^{96}$ PIMENTA BUENO, J. A. Direito Público ... op.cit. p. 287.

${ }^{97}$ PIMENTA BUENO, J. A. Direito Público ... op.cit. p. 287.
} 
que uma nova eleição manifeste o seu juízo e desejos. Se a nova maioria vem animada das mesmas idéias, então o ministério deve retirar-se; se pelo contrário é de diverso pensar, o acerto da dissolução fica demonstrado, e a harmonia restabelecida. ${ }^{98}$

Porém, mais do que isso, segundo o autor, sendo o Moderador um poder próprio da Coroa, ele deveria ser independente dos ministérios. O Imperador não exercia o Poder Executivo sem os ministros, nem os atos desse poder teriam validade sem a assinatura dos titulares das patas, cuja responsabilidade, por tais atos, seria uma garantia indispensável da sociedade. ${ }^{99}$ Contudo, se os ministros eram responsáveis pelos atos do Executivo, não deveriam sê-lo em relação ao Moderador. A despeito disso, Pimenta Bueno considera que deveria haver alguém que se responsabilizasse pelos atos do Poder Moderador. Nesse sentido, evocava a responsabilidade dos conselheiros de Estado, afirmando que mesmo a audiência sendo facultativa, tratava-se de uma soma de votos de alta garantia, obtendo-se com isto a responsabilidade dos que emitissem o voto seguido pelo Imperador ${ }^{100}$.

Ao fazer tal discussão, Pimenta Bueno remetia ao que fora estabelecido pela Lei de 15 de outubro de 1827, sobre a responsabilidade dos Ministros, Secretários de Estado e Conselheiros de Estado. Se pela lei, os ministros ficavam responsáveis por atos do Poder Executivo, do qual o Imperador era o chefe, não havia qualquer menção à responsabilidade quanto aos atos do Poder Moderador. Era justamente essa ausência, em termos legais, da necessidade ou não e, no caso afirmativo, de quem seria responsável pelos atos do Moderador, que informava parte de sua obra. Ao propor a responsabilização do Conselho de Estado, ponderava que não só as audiências deveriam ser obrigatórias e facultativas, como afirmava ter sido um erro do Ato Adicional a abolição, em seu art. 32, do Conselho de Estado previsto na Constituição $^{101}$. A obrigatoriedade, constitucional, da audiência do Conselho de Estado fazia com que o Poder Moderador estivesse abrigado pela responsabilidade dos conselheiros de Estado.

Ora, em princípio geral, e salva uma ou outra exceção, em que a responsabilidade equivalera a denegação de uma atribuição indispensável, nem um ato do poder deixar

\footnotetext{
${ }^{98}$ PIMENTA BUENO, J. A. Direito Público ... op.cit. p. 287.

${ }^{99}$ PIMENTA BUENO, J. A. Direito Público ... op.cit. p. 287.

${ }^{100}$ PIMENTA BUENO, J.A. Do Direito Público ... op.cit. p.292.

${ }^{101}$ PIMENTA BUENO, J. A. Direito Público ... op.cit. p. 292.
} 
de ter quem por ele se responsabilize. Foi por isso que a Constituição fez necessária a audiência do Conselho de Estado, e consagrou a responsabilidade dos conselheiros em sua dupla categoria, isto é, ou quando seus conselheiros são opostos às leis, a quem juram fidelidade, ou quando no silêncio delas são eles manifestamente dolosos.

$[\ldots]$

Quando não há uma responsabilidade legal, há, qualquer que seja a teoria, a vontade mais reta, inconvenientes os mais palpitantes, ou uma responsabilidade moral, que é altamente prejudicial. ${ }^{102}$

Em 1860, Zacarias de Góis e Vasconcelos, publicou sua obra Da Natureza e dos Limites do Poder Moderador, em que não só respondia às ponderações de Pimenta Bueno, mas, em sentido mais, amplo, posiciova-se do debate que então ocupava a imprensa. Segundo Silvana Mota Barbosa, a questão da responsabilidade ministerial ganhou especial destaque com a volta do Diário do Rio de Janeiro, cuja publicação havia sido suspensa em 1859. A despeito de certas divergências, fazia coro com o Correio Mercantil, no que tange à proposição de um programa político de defesa da responsabilidade ministerial, fazendo oposição ao Jornal do Comércio, considerado como folha ministerial e conservadora ${ }^{103}$. Foi justamente em meio a esse debate na imprensa que Zacarias escreveu a primeira edição de sua obra, em julho de 1860.

Ao começar a tratar do aparecimento da polêmica sobre a natureza do Poder Moderador, citava a demora de um recurso de graça (que não especificava qual fora) e a eleição para senador pela Província de Minas Gerais, na qual Teófilo Benedito Otoni, eleito em primeiro lugar na lista tríplice, não fora nomeado pelo Imperador ${ }^{104}$. Ainda comentando os debates na imprensa, Zacarias destaca o consenso do Diário do Rio de Janeiro e do Correio Mercantil em defender a responsabilidade ministerial, ao passo que o Jornal do Comércio postulava que a assinatura dos ministros vinha somente como uma autenticação da firma imperial ${ }^{105}$. Além da imprensa, Zacarias também destaca a obra de Pimenta Bueno aqui mencionada como exemplo dos "propugnadores da opinião oposta",106.

\footnotetext{
102 PIMENTA BUENO, J. A. Direito Público ... op.cit. p. 292.

${ }^{103}$ BARBOSA, Silvana Mota, A sphinge monárquica ... op.cit. p. 335.

${ }^{104}$ Com sua preterição na lista tríplice, Otoni lançou sua Circular aos Eleitores de Minas, contestando o fato de o candidato mais votado não assumir a vaga. GÓIS E VASCONECLOS, Z. Da Natureza e dos Limites do Poder Moderador in: OLIVEIRA, C.H.S. (ORG), Zacarias de Góis e Vasconcelos. São Paulo: Editora 34, 2002, p. 73.

${ }^{105}$ GÓIS E VASCONECLOS, Z. Da Natureza ... op.cit. p.74.

${ }^{106}$ GÓIS E VASCONECLOS, Z. Da Natureza ... op.cit. p.74.
} 
Em seu livro de 1860, Zacarias se propunha a mostrar que, pela Constituição de 1824 os ministros de Estado eram responsáveis pelos atos do Poder Moderador, da mesma forma que os conselheiros de Estado eram responsáveis pelos maus conselhos que dessem. Em sua opinião, com a recriação do Conselho de Estado em 1841, os conselheiros haviam voltadoa dividir com os ministros, cada qual em sua órbita, a responsabilidade pelos atos do Poder Moderador ${ }^{107}$.

Segundo Zacarias, o termo "privativamente", mencionado no art. 98 da Constituição, referia-se ao fato de a delegação ter sido feita a somente uma pessoa, o Imperador. Contudo, considerava que estava subentendido que o monarca seria auxiliado pelas "luzes de homens competentes, porque ele não pode saber tudo, e servido por agentes responsáveis, porque é para que seja, inviolável e sagrado" ${ }^{108}$. O autor ponderava que, da mesma forma que nada impedia a intervenção dos conselheiros de Estado (cuja responsabilidade estava definida em lei), não haveria motivo suficiente para excluir os ministros da responsabilidade pela execução dos atos do Poder Moderador $^{109}$. Zacarias afirma que na visão dos defensores da não-responsabilidade ministerial nos atos do Poder Moderador, o Poder Executivo estaria entregue aos $\operatorname{ministros}^{110}$.

Ambos os poderes (Moderador e Executivo) haviam sido, segundo a Constituição, confiados à mesma pessoa. Assim, a divisão em dois poderes, para Zacarias, dizia respeito a duas grandes categorias da divisão do trabalho de governar o Estado: a primeira delas constituía a atribuição de inspecionar toda a atividade política, corrigindo os excessos e, chamando os demais poderes à concórdia no caso de conflito; a segunda, seria a administração e a marcha ordinária dos negócios, considerada por ele tarefa dos ministros ${ }^{111}$. Segundo Zacarias:

A indicada divisão, porém, não embarga que, na variedade de indivíduos, a cujas mãos o chefe de Estado confia os negócios da administração, e na imensa diversidade de assuntos, que por ela correm, a unidade característica do Poder Executivo subsista

107 GÓIS E VASCONECLOS, Z. Da Natureza ... op.cit. p.79. Segundo Silvana Mota Barbosa, os defensores da referenda ministerial constantemente recorriam às fontes de direito nas quais o legislador teria se inspirado, em uma tentativa de comprovar algo que não estava textualmente na Constituição. BARBOSA, Silvana Mota, A sphinge monárquica ... op.cit. p. 325.

${ }^{108}$ GÓIS E VASCONECLOS, Z. Da Natureza ... op.cit. p.p. 81-82.

${ }^{109}$ GÓIS E VASCONECLOS, Z. Da Natureza ... op.cit. p.82.

${ }^{110}$ GÓIS E VASCONECLOS, Z. Da Natureza ... op.cit. p.p. 84-85.

${ }^{111}$ GÓIS E VASCONECLOS, Z. Da Natureza ... op.cit. p.85. 
inalterável, fazendo os ministros tudo em nome e por ordem do Imperador, centro e nexo de todos os elementos do governo do Estado, porque se os ministros procedessem com autoridade própria e como se constituíssem um poder político, o gabinete em vez de ser como a Constituição manda, um certo número de agentes, por meio de quem o imperador regesse o Estado, seria um arremedo de diretório executivo.

Da mesma sorte, a divisão de que se trata não embaraça que os ministros se cheguem à Coroa no exercício do Poder Moderador para esclarecê-la com os seus conselhos, e cobri-la com sua responsabilidade, porque de outra sorte, tornar-se-ia irremediavelmente alvo de imputações de que, por utilidade pública, deve estar isenta. $^{112}$

Zacarias considerava que, caso os atos do Poder Moderador prescindissem de referenda, seria necessário que fossem expedidos somente com o nome do Imperador, pois o Conselho de Estado tinha por atribuição somente aconselhar o monarca. O remédio para isso encontrava-se na prática que vinha sendo seguida desde a Regência, de os ministros assinarem os atos do Poder Moderador. Em sua opinião, a idéia defendida por Pimenta Bueno de que a assinatura dos ministros servia somente para autenticar a firma imperial trazia o duplo inconveniente de descobrir a Coroa e rebaixar o ministério, sendo isso admissível somente em monarquias absolutas ${ }^{113}$.

Para o autor, a garantia da responsabilidade dos conselheiros de Estado era vã porque dizia respeito somente aos conselhos opostos às leis e às conveniências públicas. Também ponderava que diversos males poderiam advir caso houvesse abuso das atribuições definidas no art. 101 da Constituição; ou seja, era preciso haver quem se responsabilizasse por esses atos para evitar crises $^{114}$.

Zacarias afirmava que a intenção do Ato Adicional fora a de aproximar o governo do modelo das monarquias parlamentares, especialmente a inglesa. Por esse sistema, o povo influía diretamente por intermédio das Câmaras na formação e dissolução dos gabinetes que deveriam ser tirados "do seio do Parlamento". Ao desenvolver esse argumento, citava uma passagem da History of England, de Thomas Babington Macaulay, que dizia: "Nossos soberanos são obrigados a proceder de acordo

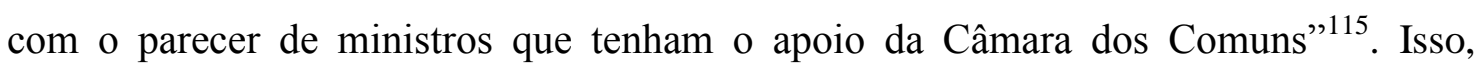
conforme se verá, foi alvo de fortes críticas de Uruguai.

\footnotetext{
112 GÓIS E VASCONECLOS, Z. Da Natureza ... op.cit. p.p. 85-86.

${ }^{113}$ GÓIS E VASCONECLOS, Z. Da Natureza ... op.cit. p.p.86-87.

${ }^{114}$ GÓIS E VASCONECLOS, Z. Da Natureza ... op.cit. p.p.88-89.

${ }^{115}$ GÓIS E VASCONECLOS, Z. Da Natureza ... op.cit. p.p.99-98.
} 
Retomando a questão da eleição senatorial, na qual Teófilo Otoni fora preterido pelo Imperador apesar de encabeçar a lista tríplice, Zacarias defendeu o direito do monarca de escolher qualquer um dos três nomes apresentados, independentemente da votação que tiveram. Contudo, pontificou que a escolha não poderia ser feita sem escrúpulos, sendo necessário se fazer um exame comparativo "do saber, da capacidade, das virtudes, e dos serviços de cada um deles". No caso da escolha senatorial, afirmava que a responsabilidade dos ministros por esse ato do Poder Moderador não faria do Senado uma expressão do partido da situação, pois o Imperador poderia muito bem tomar sua decisão sem consultar o Senado ou o Conselho de Estado, com o ministro responsável referendando esse ato ${ }^{116}$.

No Ensaio Sobre o Direito Administrativo, Uruguai trata de diversos assuntos como o Direito Administrativo e a organização do contencioso administrativo no Brasil, do Conselho de Estado ${ }^{117}$, da centralização política ${ }^{118}$ e do Poder Moderador, com destaque para o Capítulo 29 (O Imperador Reina e não Governa? O Imperador Reina e Governa?). Para fins desse capítulo, interessa-nos a discussão feita por ele sobre o Poder Moderador, na qual ele retoma diversas questões apresentadas por Pimenta Bueno, cujas idéias a esse respeito aprecia, e, contesta as idéias apresentadas por Zacarias de Góes e Vasconcelos em 1860.

Uruguai no Ensaio, procura estabelecer as diferenças entre o Poder Executivo e o Poder Moderador. O Poder Executivo, segundo ele, era dividido em Poder Executivo puro (político e governamental) e em Poder Administrativo. O primeiro era exercido pelo Chefe do Poder Executivo e seus ministros, direta ou indiretamente; enquanto o segundo teria por órgãos uma série de agentes responsáveis e amovíveis ${ }^{119}$. Quanto ao Poder Moderador, analisa os pontos discutidos por Pimenta Bueno ${ }^{120}$ e afirma, com

\footnotetext{
${ }^{116}$ GÓIS E VASCONECLOS, Z. Da Natureza ... op.cit. p.p.103-106.

117 Os dois primeiros tópicos aqui indicados serão discutidos no Capítulo 2, Razão de Estado, Direitos e Interesses.

${ }^{118}$ A análise que Uruguai faz da centralização política será objeto do Capítulo 3, Pelo Império, Contra a Província.

${ }^{119}$ URUGUAI, V. Ensaio ... op.cit. p.p. 126-127.

120 No capítulo 28 do Ensaio, denominado Exame da Questão, no qual Uruguai se propõe a analisar mais detidamente a questão do Poder Moderador, faz uma citação elogiosa de uma passagem de Pimenta Bueno, que considera uma boa explanação da definição dada pela Constituição em seu art. 98: "O Poder Moderador, cuja natureza a Constituição esclarece bem em seu art.98, é a suprema inspeção da nação, é o alto direito que ela tem, e que não pode exercer por si mesma, de examinar o como os diversos poderes
} 
isso, que os atos do Poder Moderador nada tinha haver com responsabilidade, o que significava que ele não poderia fazer o mal. Uruguai lembra que o Art. 65 da Constituição estabelecia que a denegação de sanção, ou seja, quando o monarca se recusasse a sancionar algo aprovado pela Assembléia Geral, tinha apenas suspensivo, pois se as duas legislaturas seguintes apresentassem novamente o projeto nos mesmos termos estaria entendido que o Imperador dera sua sanção. Ou seja, Uruguai entendia que, em caso de qualquer conflito do Imperador com as Câmaras, havia um remédio constitucional para a questão; a Assembléia e o Imperador apelavam então para o tempo e a vontade nacional, perante a qual o Poder Moderador teria de se curvar ${ }^{121}$.

Uruguai argumentava que a dissolução da Câmara dos Deputados tinha um caráter de apelação que o Poder Moderador fazia à nação, provocando seu juízo, fonte e origem de todos os poderes. Neste caso, Uruguai se valia do mesmo argumento utilizado para justificar que a denegação da sanção não abalava a independência do Legislativo, a seu ver, representante da nação justamente com o Imperador ${ }^{122}$. Quanto às nomeações e demissões dos ministros, defendia que elas deveriam pertencer somente ao Chefe de Estado. Para Uruguai, se houvesse a necessidade de os ministros referendarem os atos do Poder Moderador, o monarca seria então obrigado a depender da assinatura do gabinete não só para que demiti-lo. Ou seja, os ministros teriam que assinar a nomeação de seus substitutos, além de sua própria demissão.

Ainda no que diz respeito à separação entre Poder executivo e Poder Moderador, Uruguai se refere diretamente ao livro de Zacarias, discordando, entre outras coisas, com a afirmação que "na linguagem da Constituição geralmente Poder Executivo quer dizer Imperador" "123. Como expôs no Ensaio, tal asserção "felizmente não é exata", pois a Constituição empregava em certos casos o termo Imperador e em outros Poder Executivo, termos diversos por terem alcances também diversos. Para

políticos, que ela criou e confiou a seus mandatários, são exercidos. É a faculdade que ela possui de fazer com que cada um deles se conserve em sua própria órbita, e concorra harmoniosamente com os outros para o fim social, o bem-ser nacional; é quem mantém seu equilíbrio; impede seus abusos, conserva-os na direção de sua alta missão; é o fim mais ativo, o mais influente, de todas as instituições fundamentais da nação". ${ }^{120}$ PIMENTA BUENO, J.A. APUD: URUGAUAI, V. Ensaio... op.cit. p. 335.

${ }^{121}$ URUGUAI, V. Ensaio ... op.cit. p.346.

${ }^{122}$ URUGUAI, V. Ensaio ... op.cit. p.347.

${ }^{123}$ GÓES E VASCONCELOS, Z. APUD: URUGUAI, V. Ensaio... op.cit. p.349. 
Uruguai o Imperador era o primeiro representante da nação, exercendo o Poder Moderador por sua delegação, e não como chefe do Poder Executivo ${ }^{124}$.

O Imperador não é o Poder Executivo, não constitui por si só o Poder Executivo. É simplesmente o chefe do Poder Executivo. Não confundamos a parte com o todo. É o chefe de um corpo composto de agentes de cuja referenda dependem os atos desse poder, e sem a qual não podem ser executados. Por mais importante que seja a parte que possa caber ao Imperador, como chefe do Poder Executivo, nesse corpo não é ele o mesmo corpo. Os ministros, por isso mesmo que são responsáveis, não podem ser agentes passivos [grifo meu]. Podem dizer ao chefe: eu sou o responsável, e não tomo sobre mim essa responsabilidade.

O Imperador não é, portanto, o Poder Executivo. Aplicai a referenda e a responsabilidade aos atos do Poder Moderador; o Imperador pelas mesmas razões não será também o Poder Moderador, mas simplesmente o chefe do Poder Moderador. Ora, isso é contra a Constituição. ${ }^{125}$

Uruguai dedicou uma grande parte do trabalho a dialogar com o de Zacarias de Góes e Vasconcelos no tocante à questão da responsabilidade dos ministros nos atos do Poder Moderador. Paulino considerava que a referenda era desnecessária devido ao fato de não haver uma lei dizendo isto explicitamente, posição que Zacarias, ao republicar seu livro - ampliado com respostas aos argumentos apresentados pelo visconde -, continuou a repudiar, mantendo-se manteve fiel às posições defendidas anteriormente.

Em 1862, após a publicação do Ensaio, Zacarias republicou seu livro, Da Natureza e dos Limites do Poder Moderador, na qual se dedica a contestar as idéias de Uruguai. A primeira edição era composta por uma advertência ao leitor de seis páginas, duas partes: a primeira, discutida mais acima após tratarmos da obra de Pimenta Bueno, era composta por aproximadamente 48 páginas; a segunda, consistia na compilação de trechos por ele selecionados de três discursos parlamentares que proferira na Câmara dos Deputados ${ }^{126}$, perfazendo mais aproximadamente 30 páginas. Ou seja, a primeira edição totalizava 84 páginas. Na segunda edição foi acrescentada uma terceira parte, com 154 páginas (um aumento de 183\%), com o objetivo de refutar as idéias expressas no Ensaio a respeito do Poder Moderador. Na abertura da terceira parte, Zacarias afirma discordar da posição do Ensaio de que a questão do Poder Moderador "por vezes agitada entre nós nunca chegou a uma solução definitiva". Zacarias se propõe a analisar as proposições de Uruguai a respeito do Poder Moderador, "no que protesto

\footnotetext{
${ }^{124}$ URUGUAI, V. Ensaio... op.cit. p.349.

${ }^{125}$ URUGUAI, V. Ensaio... op.cit. p.p.349-350.

${ }^{126}$ Discurso proferido na sessão de 5 de julho de 1861 ; Discurso proferido na sessão de 16 de julho de 1861; Discurso proferido na sessão de 25 de julho de 1861.
} 
haver-me com a franqueza que a verdade exige, mas sempre com o respeito devido ao nome e elevada posição do autor"127.

Cecília Helena de Salles Oliveira ${ }^{128}$ chama a atenção de que para Zacarias, já na primeira edição de seu Da Natureza e dos Limites do Poder Moderador, postulava uma distinção entre deliberação e ação, cabendo a primeira à coroa e a segunda aos ministros. Tendo por base o artigo 12 da Constituição de 1824, que dizia ser o poder Moderador uma delegação da nação, Zacarias argumentaava que, assim sendo, ele - o monarca (titular de tal poder) - tinha que prestar conta de seus atos à nação e, para se preservar sua inviolabilidade, era necessário que os ministros assumissem a responsabilidade por isso. Além disso, discordava da afirmação de Uruguai de que um poder como o Moderador não poderia fazer o mal, pois uma vez que era exercido por um homem, era passível também de erros.

Esta distinção entre deliberação e ação foi atacada por Uruguai no Ensaio:

A distinção entre deliberação e ação, aplicada ao Poder Moderador, pelo modo que acabamos de ver, me parece metafísica, inútil e estéril. De que serve a deliberação a um poder, se não a pode levar a efeito, senão por meio daquele que a contesta e repele? De que serve uma deliberação que não pode sair do recinto de um gabinete e tornar-se efetiva, se aquele que a impugna não lhe der o seu assentimento, não abrir a porta? Não é possível sair desse dilema: ou os atos do Poder Moderador são exeqüíveis sem referenda ou não. Se o são, o Imperador reina e governa. Se não o são, não sei mesmo se reina, mas tenho por certo não só que não governa, como também não é o Imperador da constituição. ${ }^{129}$

A isto, Zacarias dirigiu sua tréplica, argumentando que eram as idéias de Uruguai que relegavam a Coroa à nulidade e que ao defender a fórmula de Thiers - "O Rei Reina e Não Governa" -, defendia que a Coroa tivesse sua devida influência.

${ }^{127}$ GÓIS E VASCONECLOS, Z. Da Natureza ... op.cit. p.139.

128 A autora chama a atenção para o fato de que Zacarias concorda que a natureza do Poder Moderador estava definida pela Constituição de 1824. Segundo ela, não estava em pauta a extinção do Poder Moderador ou do Conselho de Estado, como pode ser visto na própria preocupação de Zacarias com a referenda, cujo fim último era preservar a pessoa inviolável e sagrada do Imperador. Isso leva a autora a questionar até que ponto Zacarias se separou de suas antigas convicções conservadoras. Em sua opinião, ao reeditar a obra, sua intenção era consolidar os princípios que divulgara em 1860 e comprovar com documentos a linearidade de suas idéias. Ma opinião da autora, Zacarias também queria apagar as críticas que havia feito no passado recente a políticos liberais e romper seus laços com os conservadores. OLIVEIRA, C.H.S. Da Natureza e dos Limites do Poder Moderador e a Memória do Conselheiro Zacarias de Góis e Vasconcelos in: OLIVEIRA, C.H.S. (ORG), Zacarias de Góis e Vasconcelos. São Paulo: Editora 34, 2002, p.49.

${ }^{129}$ URUGUAI, V. Ensaio... op.cit. p.410. 
Com o seu dilema, o autor do Ensaio vai ser convencido de ser contra as suas intenções sem dúvida, um sectário exagerado da fórmula "o rei reina e não governa", não qual a entende Thiers, que vimos conceder à Coroa larga influência nos negócios do país, mas qual a interpretam os publicistas adversos à monarquia. No seu modo de sentir, onde não há referenda o Imperador reina e governa, mas onde há referenda o Imperador não governa, nem mesmo é certo que reine. ${ }^{130}$

Ao defender, no Ensaio, sua argumentação de que o rei "reina e governa", Uruguai citava elogiosamente uma fala de Honório na sessão da Câmara dos Deputados de 14 de junho de 1841, na qual seu finado amigo dizia que se não fosse claro na Constituição que os atos do Poder Moderador não necessitavam de referenda, não haveria a necessidade de fazer na regência uma lei a esse respeito ${ }^{131}$. Quanto à prática da referenda, que continuou corrente após a maioridade, Uruguai defendia seu posicionamento com uma citação de Pimenta Bueno, para quem ao assinarem esses atos, os ministros o faziam somente para autenticar a firma imperial ${ }^{132}$. A despeito das críticas, Uruguai não via essa prática como sendo de todo ruim, pois, em sua opinião, havia normalmente acordo entre o Poder Moderador e os ministros do Poder Executivo $^{133}$. Assim, uma vez que o Imperador e os ministros estivessem de acordo, não havia, para ele, porque separar os poderes, já que eram chefiados pela mesma pessoa. Por essa razão, afirmava que não havia a necessidade de o Poder Moderador prescindir da referenda, nos casos em que houvesse acordo entre o imperante e seus ministros, que nesses casos seriam meros tabeliães atestando que a assinatura era do Imperador. Isto, em sua opinião, era possível porque havia solução constitucional para qualquer pequena crise, não podendo os ministros almejar dominar a Coroa, pois o Poder Moderador era independente e porque a lei "constituiu-o não satélite dos ministros, mas primeiro representante da nação, e fez dele um ente inteligente e

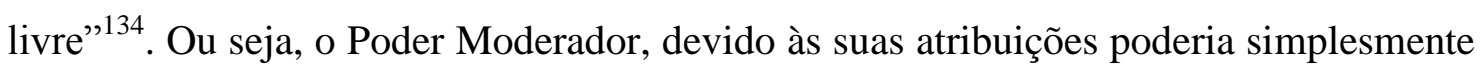
demitir os ministros que se decidissem a travar uma queda de braço com a Coroa, portanto, isso dava ao Imperador os meios de solucionar qualquer desentendimento com o ministério.

${ }^{130}$ GÓIS E VASCONECLOS, Z. Da Natureza e dos Limites do Poder Moderador in: OLIVEIRA, C.H.S. (ORG), Zacarias de Góis e Vasconcelos. São Paulo: Editora 34, 2002, p.p. 241-242.

${ }^{131}$ URUGUAI, V. Ensaio... op.cit. p.312

${ }^{132}$ URUGUAI, V. Ensaio... op.cit. p.382, nota 212.

${ }^{133}$ URUGUAI, V. Ensaio... op.cit. p.387.

${ }^{134}$ URUGUAI, V. Ensaio... op.cit. p.388. 
Zacarias atribuía ao Ensaio a idéia de que os atos do Poder Executivo eram dos ministros. Em sua visão, Uruguai reduzia o peso que o monarca deveria ter no Poder Executivo.

Aí o Imperador è perfeita nulidade.

Os actos comparativamente raros do poder moderador, em que dizeis que os ministros intervém como tabelliões do Estado para autenticarem somente a firma do Imperador, esses ficam reservados á coroa para ostentar a sua independência, não tolhendo-se todavia aos ministros que lembrem, que solicitem mesmo semelhantes atos talvez com compensação do reconhecimento da firma!

É, pois, essa doutrina do Ensaio que, por má inteligência do que seja referenda, nulifica a coroa, excluindo-a da legitima intervenção que lhe compete no exercício do poder executivo [grifo meu], ao passo que, na que se lhe opõe, a coroa exerce a mais extensa influencia nos diversos ramos do poder de sua competência, com o concurso, porém (inofensivo para a sua prerrogativa) de ministros responsáveis. ${ }^{135}$

Quanto à idéia de Uruguai de que não havia problema quanto à referenda na ausência de conflito entre o gabinete e a Coroa, Zacarias o acusava de defender interesses partidários. O pensamento de Uruguai, em sua visão, levava à diferenciação hierárquica entre gabinetes que tinham condições de abrigar convenientemente a Coroa, e outros, sem capacidade para esse fim. Para ele, em um caso os ministros gozavam de consideração, e em outro não possuíam importância; "Assim se amoldam os princípios de direito ás conveniências de pessoas e de partidos!"136

Uruguai no Ensaio, no mencionado Capítulo 29 trata das fórmulas de Thiers “O Rei Reina e Não Governa" - e a de Guizot - "O Rei Reina e Governa" -, defendendo essa última. Zacarias, por sua vez colocava-se favoravelmente à formulação de Thiers. Ao postular a formulação de Guizot, Uruguai afirmava que ela permitia que o trono não se tornasse uma cadeira vazia, mas, habilitando o monarca a ter parte ativa e real no governo. Isto, a princípio parece gerar uma contradição em relação à sua posição quanto ao poder do monarca quando da época da conciliação.

Em sua crítica à Conciliação, presente na análise que fez do Poder Moderador, Uruguai discordava do modelo proposto por Zacarias de que o ministério deveria ser um reflexo da maioria parlamentar, especialmente da Câmara dos Deputados. Em sua visão, um homem experiente nos negócios públicos como o monarca não poderia ficar

${ }^{135}$ GÓIS E VASCONECLOS, Z. Da Natureza e dos Limites ... op.cit. p. 242.
${ }^{136}$ GÓIS E VASCONECLOS, Z. Da Natureza e dos Limites ... op.cit. p. 204. 
refém da referenda de "moços" inexperientes. Sobre o sistema da maioria das Câmaras dizia ele:

Pode marchar esse sistema com ministérios fortes, compostos de estadistas de primeira ordem, que gozem de grande consideração da Coroa e das Câmaras, por meio da qual consigam o necessário acordo. Pode marchar, por algum tempo, com os Guizots, mas os Guizots são raros e por hora ainda não nos tocou nenhum. Pode marchar um ministério com esse sistema quando se apóia em um forte e grande partido [grifo meu] [...] Quando porém, não há partidos com princípios bem discriminados, quando não há grandes interesses e questões que dividam e agitem a população, quando as maiorias das Câmaras são incertas e flutuantes, quando os ministérios são fracos, é o sistema impraticável.

Estamos nós, principiantes de ontem, em circunstâncias de pôr em exame todas essas belas e engenhosas teorias, de ter sempre ministérios com o necessário vigor para dar vigoroso impulso a tais sistemas? Tivemos o ministério de 19 de setembro ${ }^{137}$, com a sua possante e compacta maioria. ${ }^{138}$

Conforme discutido ao final do item 1.1, no discurso de 28 de maio de 1858 no Senado Uruguai dirigiu críticas diretas à Conciliação, afirmando que ela estava fazendo desaparecerem os partidos. Vale aqui retomarmos uma reflexão feita por Needell. Segundo o historiador norte-americano, o conceito de partido naquela época não era aquilo que entendemos hoje como partido. Sua principal característica, segundo Needell, era "um senso de liderança altamente pessoal", cuja marca seria a ausência de uma agenda ideológica e, paralelamente, uma profunda relação com redes de parentesco e de interesses muito específicos como raça e nacionalidade ${ }^{139}$. Ora, isto é importantíssimo para questionarmos para compreender o pensamento de Uruguai sobre o poder do Imperador. Quando houve o pedido de demissão coletiva, Paulino era então ministro. Uma maior interferência do monarca na política do gabinete significava, em 1852, uma intervenção na política dos saquaremas. Contudo, o contexto de 1862 era diverso. Ao reclamar que não havia partidos definidos, Uruguai estava reclamando do fato de os "moços" da Câmara não respeitarem a liderança pessoal de políticos mais

\footnotetext{
${ }^{137}$ Trata-se do ministério da regência de Pedro de Araújo Lima, no qual figurava Bernardo Pereira de Vasconcellos, figura altamente admirada por Uruguai.

${ }^{138}$ URUGUAI, V. Ensaio Sobre o Direito Administrativo. in: CARVALHO, J.M. (ORG), Visconde do Uruguai. São Paulo, Editora 34, 2002, p. 423. Uruguai termina esse raciocínio falando que no futuro poderia aparecer outro ministério como esse, porém, ressalva com uma citação em latim do poeta latino Orácio: "Neque semper idem floribus est bonos / Vernis, neque uno Luna rubens nitet / Vultu. [Não há sempre o mesmo encanto nas flores da primavera, nem brilha a risonha lua com a mesma aparência.]

${ }^{139}$ NEEDELL, J. Formação dos Partidos Políticos no Brasil da Regência à Conciliação (1831-1857) in: Almanack Braziliense, ${ }^{\circ} 10$, novembro/2009, p.7.
} 
experientes que se encontravam no Senado ${ }^{140}$. Ou seja, o que ocorria era que em 1862 os "emperrados" já não possuíam o mesmo espaço que tiveram nas décadas anteriores. Perderam espaço ao se colocarem contra a interferência do monarca. Defender que o Imperador governe em 1862 aparece como um oportunismo político, de quem, alijado do poder no período de praticamente uma década, via na defesa do monarca governante a oportunidade de recuperar, ainda que em parte, o espaço perdido.

No Capítulo 27 do Ensaio - Do Poder Moderador -, Uruguai mostra que os defensores da referenda da década de 1860 simplesmente repetiam argumentos que os exaltados já haviam proferido na década de 1830. Uruguai faz essa comparação para afirmar que as lideranças políticas que começavam a despontar na década de 1860 não tinham qualquer inovação a propor. Neste sentido, Silvana Mota Barbosa afirma que alguém como Uruguai, atuante por tanto tempo na política nacional "poderia de fato considerar os moços da Câmara mal preparados para participarem do ministério"141.

Segundo Uruguai, era impossível manter maiorias sem chefes, e quando ocorria de elas governarem exclusivamente (como queria Zacarias), assumiam, do mesmo modo que seus chefes, uma importância extraordinária. Isso, em sua opinião, aqueles

\footnotetext{
${ }^{140}$ Sérgio Buarque de Holanda considera que devem ser levantadas objeções contra a idéia de governos conservadores sem mescla no período de 1857 a 1862. Em sua opinião, isto seria ignorar tentativas feitas no gabinete da Conciliação e nos seguintes de dar aos liberais posições de prestígio na política. $\mathrm{O}$ gabinete Olinda sofreu forte oposição por parte dos saquaremas em 1858. Com a reforma da lei bancária, que colocava grande quantidade de moeda em circulação, o ministro da Fazenda Bernardo de Souza Franco teve de enfrentar duros ataques dos saquaremas (Itaboraí, Eusébio de Queiroz e Uruguai) no Senado. Ao gabinete Olinda sucedeu outro, presidido pelo Visconde de Abaeté. Francisco de Salles Torres Homem, ministro da Fazenda iniciou a revogação de diversas medidas do gabinete anterior. Entretanto, sem muitas forças, se retirou no ano seguinte, sendo substituído pelo gabinete de 10 de agosto de 1859, presidido por Ângelo Muniz da Silva Ferraz. Neste gabinete foi aprovada uma reforma da Lei dos Círculos. Ao invés dos círculos eleitorais elegerem um deputado passaram a eleger três. As eleições de 1860 , que se seguiram à aprovação da lei, na visão de Richard Graham, dividiram tanto conservadores como liberais. Nesta legislatura, moderados de ambos os partidos se agruparam na chamada Liga Progressista. Segundo Holanda, a nova Câmara eleita contava com uma forte oposição ao ministério, o que precipitou a queda do gabinete, subindo em seu lugar o gabinete de 3 de maio de 1861 , presidido por Caxias, que foi substituído em 1862 por Zacarias de Góes e Vasconcelos.Com seis dias de governo, Zacarias cai e Olinda é novamente chamado a presidir o Conselho de Ministros. Seu ministério dura até 1864, quando é substituído por Zacarias. Parte da historiografia denomina o período compreendido entre a ascensão do segundo gabinete Zacarias em 1864 e a queda de seu terceiro gabinete em 1868 de segundo qüinquiênio liberal. Essa idéia, no entanto, é controversa, pois conforme indica Holanda, não houve um predomínio exclusivo dos liberais nesse período, havendo um maior, mas não exclusivo, predomínio progressista. HOLANDA, S.B. H. História Geral da Civilização Brasileira Volume 7: Do Império à República. Bertrand Brasil, Rio de Janeiro, 1997, p.p. 22-28. GRAHAM, R. O Brasil de Meados do Século XIX à Guerra do Paraguai in: Bethell, L. (org.), História da América Latina, Da Independência a 1870. São Paulo:EDUSP \& Imprensa Oficial, 2001, p. 811.

${ }^{141}$ BARBOSA, Silvana Mota, A sphinge monárquica ... op.cit. p. 335.
} 
que compõem e dirigem as maiorias, tornam-se muitas vezes caprichosos e intolerantes, menos preocupados com os interesses gerais da nação que em ajeitar, disciplinar e conservar arregimentadas e satisfeitas as maiorias. Segundo Uruguai:

Logo que a sociedade cansa, e se aborrece dessas lutas, logo que as suas causas desaparecem ou mínguam, logo que as feições dos partidos deixam de ser bem distintas e bem pronunciadas, logo que esses princípios e interesses não estão em perigo, a antiga disciplina dos partidos afrouxa-se e perde-se, e torna-se o governo exclusivo das maiorias parlamentares impraticável. ${ }^{142}$

Quando isso ocorria, segundo Uruguai, as maiorias eram fracionadas em diversos grupos, cada um com seu respectivo chefe, o que impedia a existência de ministérios inteiriços. Como conseqüência, esses grupos se viam obrigados a fazer coalizões, que resultavam em ministérios fracos e de pouca duração ${ }^{143}$. Para Uruguai, o governo parlamentar era somente possível com homens excepcionais como Guizot. "São precisas notabilidades diante das quais as de segunda e terceira ordem abaixem a cabeça"144.

Porém, Uruguai julga o sistema das maiorias parlamentares, ou seja, o parlamentarismo britânico, era completamente impraticável no Brasil, pois além de não haver partidos definidos, a Câmara dos deputados contava com muitos "moços de talento e esperançosos", mas que não se subordinavam aos chefes e que ainda não possuíam "aquela consagração que só dão o tempo ou os grandes feitos em grandes lutas". Segundo Uruguai, aqueles que adquiriam experiência, nome, relações e adesões, ao chegarem aos 40 anos procuravam refugiar-se no Senado contra a instabilidade das eleições, "cansados do trabalho que dão e da extrema dependência em que põem os candidatos" ${ }^{\prime 145}$. Assim, considerava que a Constituição do Império não permitia o governo exclusivo das maiorias parlamentares, e principalmente da Câmara dos Deputados; até porque a Assembléia Geral era composta das duas casas o que fazia com que a Câmara dos Deputados fosse somente um pedaço do Poder Legislativo. Assim, para além da câmara temporária, havia, conforme o visconde, mais duas

\footnotetext{
${ }^{142}$ URUGUAI, V. Ensaio ... op.cit. p.419.

${ }^{143}$ URUGUAI, V. Ensaio ... op.cit. p.419.

${ }^{144}$ URUGUAI, V. Ensaio ... op.cit. p.420.

${ }^{145}$ URUGUAI, V. Ensaio ... op.cit. p.421.
} 
frações: o Senado e o Imperador, declarado este pela Constituição como o primeiro representante da nação ${ }^{146}$.

Ou seja, quanto ao sistema da maioria, ponderava que:

Pode marchar este sistema com ministérios fortes, compostos de estadistas da primeira ordem, que gozem de grande consideração e prestígio da Coroa e das Câmaras, por meio da qual consigam o necessário acordo. Pode marchar, por algum tempo, com os Guizots, mas os Guizots são raros e por ora ainda não nos tocou nenhum. Pode marchar um ministério com esse sistema quando se apóia em um forte e grande partido. Então poderá melhor dispensar meios que gastam e desacreditam o poder e que corrompem. Mas poderão aquelas circunstâncias ser permanentes?

Quando porém não há partidos com princípios bem discriminados, quando não há grandes interesses e questões que dividam e agitem a população, quando a maioria das Câmaras são incertas e flutuantes, quando os ministérios são fracos,é o sistema em questão impraticável. ${ }^{147}$

Isto nos faz retornar à colocação de Needell a respeito dos partidos no Império, para quem sua marca era a liderança personalista. Na década de 1850, a interferência do Imperador no Poder Executivo se dera no sentido de reduzir a liderança dos chefes partidários, a partir das mudanças eleitorais e da tentativa de reforma da Lei de 3 de dezembro. A Lei dos Círculos não só instituiu o voto distrital, como também impediu que funcionários públicos se elegessem nos círculos onde exerciam jurisdição. Isto certamente atrapalhava as redes de parentesco e de apoio eleitoral que o gabinete possuía e que lhe garantiam uma eleição satisfatória. Doravante, torva-se necessário negociar muito mais e, conseqüentemente, ofertar mais nomeações. Uruguai, reiterando o que dissera na citação acima, afirma que, no que tange à força necessária para manter o sistema das maiorias parlamentares, era preciso lembrar do "ministério de 29 de setembro, com sua possante e compacta maioria, e porventura mais algum outro ..."148

Ou seja, o que Uruguai estava afirmando é que o único ministério forte fora aquele composto pela trindade saquarema, o que significava que o único grupo com força para garantir as maiorias parlamentares era justamente o seu. Esse gabinete representou o auge do poder dos saquaremas. Aqui, tiveram sua queda de braço com o Imperador e ganharam, ao ponto de ser conservada a maioria dos ministros com a

\footnotetext{
${ }^{146}$ URUGUAI, V. Ensaio ... op.cit. p.p. 421-422.

${ }^{147}$ URUGUAI, V. Ensaio ... op.cit. p.423.

${ }^{148}$ URUGUAI, V. Ensaio ... op.cit. p.423. Conclui essa passagem com um verso de Horácio que diz: "não há sempre o mesmo encanto nas flores da primavera, nem brilha a risonha lua com a mesma aparência.” URUGUAI, V. Ensaio ... op.cit. p.424, nota 129.
} 
reorganização do gabinete em 1852. Contudo, perderam a partir de 1853 . Em 1862 já não mais possuíam a mesma força de outrora. Não era o momento para se contraporem à vontade do Imperador, pelo contrário, no novo cenário político para terem força, inclusive para se impor aos "moços indisciplinados" da Câmara, dependiam da anuência de Pedro II.

A questão da troca de cargos por apoio político foi debatida, em 1862, pelo próprio monarca diretamente com o Visconde do Uruguai. No dia 25 de janeiro, o Imperador anotou em seu diário que Uruguai mandara-lhe o que havia de impresso de sua obra. Três dias depois, o monarca já teria começado a ler as páginas do Ensaio, com o qual, conforme registrou, concordava em relação às ponderações acerca dos abusos feitos na política. A 30 de janeiro, Dom Pedro II anotou que acabara de ler o que tinha da obra de Uruguai e que discordava de alguns pontos. Segundo o monarca, havia uma nota sobre o Patronage executive (sistema pelo qual o governo trocava a nomeação para cargos de sua jurisdição por apoio político) na Inglaterra, onde Uruguai afirmava que as injustiças feitas ao merecimento individual eram um mal irremediável do sistema que regia o Brasil, porque somente assim poderiam ser formados partidos, que ele lamentava que estivessem praticamente mortos. De acordo com o Imperador, Uruguai afirmava que o Patronage Executive não deveria ser apenas exercido pelo ministro diretor da política, mas sim por todos os ministros que, em geral, eram pessoas novas, carentes de criar sua clientela. Pedro II terminou as anotações do dia 30 de janeiro de 1862, afirmando que estas reflexões de Uruguai pareciam-lhe "destruir o que de tão verdadeiro dissera ele antes dos efeitos da política entre nós. Hei de conversar com o Uruguai a respeito desta questão e sobre outros pontos de sua obra."149

A conversa ocorreu praticamente um mês depois, no dia 27 de fevereiro. Anotou D. Pedro II, em seu diário, que concordara com diversas explicações que Uruguai lhe dera, mas que ainda discordava quanto ao patronato executivo, sendo que, mesmo no caso da Inglaterra, Uruguai não admitia que se tratava somente de um fato cujas causas cumpria remover, ou seja, que era um sistema que não deveria ser alimentado. O Imperador fez também apontamentos acerca dos diversos pontos

\footnotetext{
149 Diário do Imperador Dom Pedro II in: Anuário do Museu Imperial. Petrópolis: Ministério da Educação e Cultura, 1956, p. 40.
} 
discutidos entre ambos, como a oposição parlamentar aos gabinetes, a Conciliação e a questão da referenda dos atos do Poder Moderador. Quanto à questão da referenda, simplesmente parafraseava a posição que Uruguai defendia no Ensaio, sem se posicionar a respeito. Sobre a Conciliação, afirmou:

Tratando da introdução comuniquei-lhe a observação que eu fizera ao Paraná sobre a política da Conciliação à qual ele respondera perguntando se deveria repelir quem o procurasse, o que revela qual o pensamento dessa política. Acrescentei que sem uma boa lei eleitoral que consinta a todos os partidos esperar não se podem eles formar regularmente e que eu continuava a julgar boa a lei primitiva dos círculos. O Uruguai nada disse a tal respeito, senão que admitia a conciliação como eu a entendia. ${ }^{150}$

Finalizava suas anotações afirmando esperar a manifestação de posições contráriasà obra de Uruguai, pois se tratava, no seu entender, de uma obra que defendia que uma administração bem organizada supria até certo ponto a liberdade política. Porém, se fosse uma oposição que tratasse de esclarecer estes pontos ao país, seria algo muito vantajoso ${ }^{151}$.

A concordância de Uruguai com a posição do monarca sobre a Conciliação foi certamente retórica, pois além de não fazer qualquer consideração sobre isso, estava diante do primeiro representante da nação. Provavelmente tratava-se de deferência a d. Pedro II, o que é perfeitamente compreensível para quem afirmava que o Poder Moderador era um poder "o qual como Deus de quem emana, em parte alguma tem limites" ${ }^{\prime 152}$. Contudo, o Imperador não conseguiu demover Uruguai de suas posições a respeito do patronato executivo. No próprio Ensaio, afirmava que o sistema que ajudou a montar, meadiante a aprovação da Lei de 3 de dezembro, beneficiara inclusive os liberais. Em sua visão:

Se quando o Partido Liberal dominou o poder no Ministério de 2 de fevereiro de 1844, não tivesse achado a Lei de 3 de dezembro de 1841, que combateu na tribuna, na imprensa, e com as armas na mão, e na qual não tocou nem para lhe mudar uma vírgula, se tivesse achado o seu adversário acastelado nos castelos do sistema anterior, ou teria caído logo ou teria saltado por cima das leis. Cumpre que na organização social haja certas molas flexíveis, para que não quebrem quando aconteça, o que é inevitável, que nelas se carregue um pouco mais. ${ }^{153}$

150 Diário do Imperador Dom Pedro II in: Anuário do Museu Imperial. Petrópolis: Ministério da Educação e Cultura, 1956, p. 57.

151 Diário do Imperador Dom Pedro II in: Anuário do Museu Imperial. Petrópolis: Ministério da Educação e Cultura, 1956, p. 58.

${ }^{152}$ URUGUAI, V. Ensaio ... op.cit. p. 361.

${ }^{153}$ URUGUAI, V. Ensaio ... op.cit. p. 466. 
Isto nos faz retornar mais uma vez à questão de porque em 1851 Paulino de Souza defendia um determinado posicionamento em relação à ingerência do Imperador no Poder Executivo e, em 1862 seu discurso era diverso. Talvez para ele a intervenção do monarca na política não constituísse um problema se os partidos estivessem claros e tivessem eles à sua mão o sistema do patronato executivo para poderem se manter. A resposta à questão também pode ser buscada em duas passagens do livro do visconde. Ao tratar da separação entre Moderador e Executivo, conforme visto, deixou bem claro que, no tocante ao Executivo, os ministros não podiam ser agentes passivos e, uma vez que não concordassem com as decisões do chefe do poder (no caso o monarca), podiam pedir sua exoneração. Ora, isso nos remete justamente ao que ocorrera em 1851. Naquela ocasião o Imperador desejava ver implementada uma determinada política que o gabinete não se dispunha a seguir, razão pela qual ofereceu seu pedido de exoneração coletiva. Isso pode ser considerado como uma queda de braço entre o gabinete de 1848 e o Imperador, em que coube ao último ceder, uma vez que as alterações feitas nas pastas, em 1852, não podem ser consideradas alterações bruscas.

Zacarias ao contestar Uruguai é categórico ao afirmar que a doutrina do Ensaio excluía o Imperador da "legítima intervenção que lhe compete no exercício do Poder Executivo". No entanto, Uruguai defendia que o monarca deveria ter um papel ativo na condução da política, conforme pode ser visto em sua defesa de Guizot em oposição a Thiers. Poderia então se tratar de uma necessidade que Uruguai via de se separar claramente os poderes, sendo o Poder Moderador privativo do Imperador que não estava sujeito a responsabilidade alguma, e o Executivo, apesar de chefiado pelo Imperador, deveria ter uma menor intervenção dele, pois era exercido pelos ministros que, como o próprio Uruguai afirmava, não podiam ser agentes passivos quando se tratava desse poder.

Os partidos, conforme escrevia o visconde em inícios da década de 1860, não estavam mais claramente definidos e a Câmara dos Deputados contava com muitos homens novos, sem experiência e que não se subordinavam aos chefes partidários. A Conciliação caracterizara-se por uma ingerência maior de dom Pedro II na política dos gabinetes, impondo, como uma de suas metas o fim do patronato executivo. Ora, o 
patronato executivo era justamente um dos pilares do sistema que os regressistas haviam montado. Em sua empreitada de tentar liquidar o patronato executivo, o Imperador enfraquecia a liderança personalista que os saquaremas exerciam no partido conservador. Assim, a oposição de Uruguai a uma maior ingerência do monarca no Poder Executivo está ligada ao enfraquecimento do poder de seu grupo com as reformas que o imperante desejava ver realizadas.

Contudo, cabe lembrar que Uruguai é mais político que teórico. Essa mudança de discurso se inseria em um quadro mais amplo: os saquaremas haviam perdido espaço. Pedro II deixou claro na Conciliação que ele daria as cartas na política dos gabinetes. Para poder recuperar parte do espaço perdido, dentro do novo contexto político, os saquaremas precisavam sinalizar que não fariam outra queda de braço com o Imperador. Contudo, deve ficar claro que recuperar espaço, não significava necessariamente voltar ao ministério, pois o próprio Uruguai já havia recusado duas vezes. Se em 1862 teria aceitado jamais saberemos. Provavelmente, não aceitou quando teve a oportunidade, por não desejar ser um ministro das Idéias Gerais. O ponto principal continuava a ser o mesmo que originara o pedido de exoneração coletiva em 1851 e as divergências com Honório em Pernambuco: o patronato executivo. Por esse sistema, o processo eleitoral passava por diversas negociações de cargos de nomeação pelo governo central. Os saquaremas tinham construído sua direção a partir desse sistema. Todavia, se a defesa de que o monarca governasse tinha por objetivo a conquista de maior espaço político, a defesa do patronato executivo, ainda que apresentado como um mal necessário, continuava a ser motivo de discórdia com o Imperador. Contudo, se o cenário político passava por mudanças e, Uruguai não conseguiu persuadir o Imperador quanto a suas idéias, conseguiu, ao publicar o Ensaio, divulgá-las da forma mais ampla possível para sua época. Isso, certamente, rendeu-lhe uma longevidade no debate político mesmo após a sua morte. 


\title{
CAPÍTULO 2: RAZÃo DE ESTADO, DIREITOS E INTERESSES
}

\begin{abstract}
Porém, desde que V.Ex. me pediu que me encarregasse de redigir alguma cousa sobre o assunto, tenho tido sempre a atenção ocupada com trabalhos, dos quais, como conselheiro de Estado, hei sido incumbido, sobre assuntos graves e variados, de modo que não me tem sido possível entregar-me como era necessário à minuciosa revisão de nosso abstruso e deficiente sistema administrativo, para verificar bem como e por que modo hão de juntar-se a essa defeituosa máquina as novas peças que o governo the quer por com jeito, de modo que jogue bem. ${ }^{154}$
\end{abstract}

Essa passagem de Uruguai é uma resposta ao Aviso de 19 de agosto de 1857, pelo qual o Marquês de Olinda, então Presidente do Conselho de Ministros, criara uma comissão encarregada de elaborar bases para melhorar as administrações provinciais e fazer com que a autoridade fixada nas capitais das Províncias fosse sentida nas diversas localidades.

Uruguai, membro da comissão, ficara encarregado de formular as bases que serviriam de ponto de partida para a discussão. Segundo o Aviso, a finalidade desse projeto a ser elaborado na comissão era de dotar as administrações provinciais de instituições que não só as auxiliassem com o seu conselho, mas também ajudassem as autoridades provinciais nos lugares mais distantes do governo central ${ }^{155}$.

No Aviso, Olinda elaborou uma série de quesitos a respeito dos quais seria necessário dar resposta. $\mathrm{O}$ primeiro quesito tratava da conveniência ou não de se criar um Conselho de Presidência de Província. Caso a resposta fosse positiva, haveria outras questões a serem respondidas acerca de sua organização e dos objetos de sua competência. O segundo quesito perguntava sobre a conveniência de se criar autoridades administrativas centrais, subordinadas aos presidentes de Província. No caso de resposta afirmativa, a comissão era chamada a responder se a estas autoridades, subordinadas ao Presidente, poderiam ser delegados poderes para resolverem negócios,

\footnotetext{
${ }^{154}$ URUGUAI, V. Bases Para Melhor Organização das Administrações Provinciais. Rio de Janeiro, Typografia Nacional, 1958, p.2.

${ }^{155}$ URUGUAI, V. Bases ... op.cit. p.1.
} 
embora a decisão final ficasse a cargo do Presidente. Também era perguntada a conveniência de se determinar os casos em que os Presidentes poderiam delegar poderes a estas autoridades, podendo elas resolver por si, assim como qual deveria ser o território de sua jurisdição ${ }^{156}$.

Ou seja, o Aviso pedia à comissão para elaborar um projeto para levar a autoridade do presidente da Província às localidades e, principalmente, para criar mecanismos para dirimir conflitos na própria localidade, com autoridades subordinadas ao Presidente. Tratava-se de dar forma ao contencioso administrativo, organizando-o em primeira e segunda instância e, como conseqüência, desafogar o Conselho de Estado que, entre outras funções, constituíra-se em Corte Administrativa.

Antes de tratar dos desdobramentos do Aviso, é necessário contextualizar o contencioso administrativo e seu funcionamento no Brasil oitocentista.

\section{1 - O CONTENCIOSO ADMINISTRATIVO E SEU FUNCIONAMENTO NO BRASIL IMPÉRIO}

Contencioso administrativo, em linhas gerais, consiste no sistema pelo qual os atos da administração não são julgados pelos tribunais comuns, mas pela própria administração. No caso do Brasil imperial, seu órgão de cúpula era o Conselho de Estado ${ }^{157}$. Na Seção de Justiça e Negócios Estrangeiros do Conselho de Estado, Uruguai foi relator de importantes pareceres.

Bartolomé Clavero define o Direito Administrativo como uma criação histórica francesa, que surge como um contraposto à rule of law ${ }^{158}$, se apresentando como um

\footnotetext{
${ }^{156}$ URUGUAI, V. Bases Para Melhor Organização das Administrações Provinciais. Rio de Janeiro, Typografia Nacional, 1958, p.1.

157 JUNIOR, J. C. Contencioso Administrativo-I; In: FRANÇA, R. L. (org.), Enciclopédia Saraiva do Direito. São Paulo, Saraiva, 1979, Volume 19, p. 9-11.

${ }^{158}$ Segundo Nicola Matteucci, a rule of law constitui uma experiência constitucional singular inglesa, “conceito tão difícil de definir quanto de traduzir". Segundo o autor, essa expressão fixa-se na Inglaterra no século XVII, assentada, a seu ver em motivos medievais, com o intuito de afirmar a igualdade dos cidadãos perante a lei, para, com isso, combater o arbítrio do governo. Matteucci destaca que a cultura inglesa se caracterizou pela afirmação da autonomia do direito em relação ao governo, e a necessidade de subordinar o governo ao direito. Isso teria sido possível não somente pela independência dos juízes ingleses em relação ao poder político, como também pela common law, direito do qual os juízes são considerados conservadores e depositários. O juízes julgam com referência aos precedentes judiciários, ou por meio da interpretação das leis do Parlamento de acordo com os princípios gerais do direito contidos na common law. Contudo, com a afirmação do poder parlamentar no século XVIII, a common law, segundo Matteucci teve a sua supremacia reduzida. O autor destaca que Albert Venn Dicey, autor de
} 
regime não constitucional, no qual um poder teoricamente Executivo se situa e age à margem de toda a capacitação estritamente constitucional, tanto de direção legislativa como de habilitação judicial, dotando-se e fazendo uso de uma faculdade reguladora autônoma e de uma competência jurisdicional própria ${ }^{159}$.

Já tratando do caso brasileiro, José Reinaldo de Lima Lopes coloca que desde a Assembléia Constituinte de 1823, parecia unanimidade entre os legisladores de que a nova justiça que estava sendo criada ${ }^{160}$ deveria ser isolada das decisões políticas. Em sua visão, seria essa a origem da justiça administrativa e do direito administrativo. Lopes destaca o trabalho de Albert Venn Dicey, publicado em 1885, no qual o autor afirma que o regime constitucional dos franceses, que consagrava a existência de um limite à justiça ordinária, acabava por estabelecer um limite à liberdade constitucional dos cidadãos ${ }^{161}$. Lopes cita como exemplo de cerceamento à liberdade uma fala de Alexis de Tocqueville na qual ele relata a seus interlocutores norte-americanos que na França um cidadão prejudicado pela ordem do príncipe, ficava limitado a pedir ao próprio príncipe a autorização para obter justiça ${ }^{162}$. Segundo Fernando Martinez a

Introduction to The Study of The Law of The Constitution em 1885 como o maior teórico do rule of law. Dicey mostra como na Constituição inglesa está suposta a exclusão do poder discricionário, ou mesmo arbitrário, de modo a igualar o cidadão com o governo perante os tribunais. Isso impossibilitava que, assim como na França, houvesse tribunais administrativos. MATTEUCCI, N. Constitucionalismo in: BOBBIO, N. MATTEUCCI, N. PASQUINO, G. Dicionário de Política. Brasília, Editora UnB, 1998, p. 252. Clavero considera rule of law uma invenção de Dicey. Foi, para Clavero, idéia de Dicey a adoção dessa expressão, conformando-a de modo que servisse para identificar e construir um elemento definido do constitucionalismo britânico. A seu ver, rule of law nasce como algo distinto de império da lei, se definindo como regra de competência da justiça a respeito da common law, direito comum inglês e não à uma lei. Assim, Clavero considera que rule of law não é regra da lei no sentido de uma norma ou uma determinação política. CLAVERO, B. Happy Constitution, Cultura y Lengua Constitucionales. Madrid, Editorial Trota, 1997, p. 191.

159 CLAVERO, B. Happy Constitution, Cultura y Lengua Constitucionales. Madrid, Editorial Trota, 1997, p. 193.

160 A Constituição de 1824 em seu Título 6º , Capítulo Único definiu as atribuições do Poder Judiciário. $\mathrm{O}$ teor do texto mostra como tratava-se de um aparato ainda para ser montado. Previa a criação de Relações e previa a criação do Supremo Tribunal de Justiça (STJ). No dia 18 de setembro de 1828 foi promulgada a Lei de Constituição e Composição do Supremo Tribunal de Justiça. Dias depois foram promulgadas leis extinguindo instituições judiciárias herdadas de Portugal como a Mesa do Desembargo do Paço, a Mesa de Consciência e Ordens (22 de setembro de 1828) e o Tribunal da Bulla da Cruzada (20 de setembro de 1828). Ver: SLEMIAN, A. Sob o império das leis: constituição e unidade nacional na formação do Brasil (1822-1834). São Paulo, Tese de Doutorado, FFLCH/USP, 2006, especialmente o Capítulo 1: Do Império português ao Império do Brasil.

${ }^{161}$ LOPES,J.R.L, O Supremo Tribunal de Justiça no Apogeu do Império (1840-1871). in: LOPES,J.R.L (org.), O Supremo Tribunal de Justiça do Império (1828-1889). São Paulo, Editora Saraiva e Fundação Getúlio Vargas, 2010, p. 65-66.

${ }^{162}$ LOPES,J.R.L, O Supremo Tribunal de Justiça ... op.cit. p. 66, nota 1. 
história do Direito Administrativo se relaciona com o alargamento das competências atribuídas à administração, como a transformação da "chave judicial" em "chave administrativa", em um âmbito continental, o que contrasta com a persistência da “chave juducial" no contexto anglo-saxão ${ }^{163}$.

Lopes afirma que no direito pré-moderno a justiça se ocupava de questões distributivas, ou seja, "era comum que os órgãos judicantes fossem órgãos da

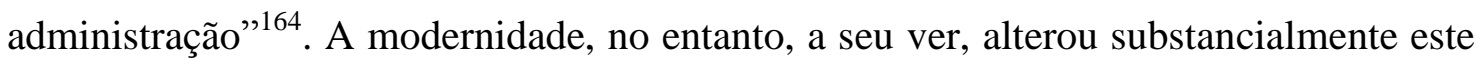
quadro, pois até então, a promoção da justiça era função do soberano, que detinha o Poder Político. Maurizio Fioravanti destaca que da constituição moderna prefigurada e sustentada por Hobbes e Rousseau, resultavam duas operações, a princípio, impossíveis para esses autores ${ }^{165}$. A primeira operação seria a da divisão do poder soberano em uma pluralidade de poderes públicos contrapesados entre si e limitados reciprocamente. A segunda operação consistiria na possibilidade de individualizar um limite legal à extensão dos poderes do soberano, podendo opor a esses poderes uma norma fundamental como garantia e tutela dos indivíduos ${ }^{166}$.

Segundo Lopes, o contratualismo ${ }^{167}$ concentrou a vida jurídica em um sistema de relações intersubjetivas bilaterais, sendo a esfera da justiça distributiva alocada à

\footnotetext{
${ }^{163}$ MARTINEZ, F. La Historiografía de las Instituciones Administrativas en España (siglos XIX-XX, p.7 Disponível em: http://revista.fajardolopez.com/index.php?name=Sections\&req=viewarticle\&artid $=39$ \&allpages $=1 \&$ theme $=$ Printer.

${ }^{164}$ A justiça distributiva diz respeito a um fenômeno que José Reinaldo de Lima Lopes considera o de uma politização do sistema judicial, ou seja, o envolvimento dos tribunais em casos cuja decisão envolve mais do que as partes que se apresentam em juízo, normalmente reivindicando quer os chamados direitos sociais, quer reivindicações por direitos civis ou políticos. Neste arbítrio de questões distributivas inserese o direito público. Segundo Lopes, até o século XVII a justiça distributiva era assunto comum aos juristas. LOPES, J.R.L. As Palavras e a Lei. Direito, Ordem e Justiça na História do Pensamento Jurídico Moderno. São Paulo, Fundação Getúlio Vargas e Editora 34, 2004, p. 197-236. Trecho citado da p.198.

${ }^{165}$ Fioravanti considera que Hobbes e Rousseau não poderiam vislumbrar a idéia de que era possível combinar um poder que fosse a expressão da soberania, mas que não fosse indivisível e ilimitado por sua natureza. FIORAVANTI, M. Constituición, De La Antiguedad a Nustros Días. Madrid, Trota, 2001, p.86.

${ }^{166}$ FIORAVANTI, M. Constituición ... op.cit. p.86.

167 O contratualismo, segundo Nicola Matteucci, compreende, em sentido amplo todas as teorias políticas que consideram a origem da sociedade e o fundamento do poder político baseados em um contrato, que seria uma espécie de acordo tácito ou expresso, celebrado pela maioria dos indivíduos para por fim ao seu estado de natureza e inaugurar o estado social e político. Segundo Metteucci, em sentido restrito, o termo contratualismo designa uma escola que despontou entre o início do século XVII e final do século XVIII, cujos maiores expoentes são: Johanes Althusius (1557-1638); Thomas Hobbes (1588-1679); Benedict de Spinoza (1632-1677); Samuel Puffendorf (1632-1694); John Locke (1632-1704); Jean Jacques Rousseau (1712-1778); e Immanuel Kant (1724-1804). Matteucci ressalta que há grandes
} 
política. Uma das contribuições do jusnaturalismo consistiu em aumentar a autonomia do direito, conferindo-lhe as decisões a respeito de casos comutativos, ou seja das relações bilaterais entre os cidadãos. Como conseqüência, viu-se o surgimento de duas jurisdições: para os casos comutativos os tribunais judiciários e para os casos distributivos os órgãos da administração ${ }^{168}$ No caso de haver conflitos entre a administração e os particulares, eles seriam arbitrados em órgãos administrativos especiais ${ }^{169}$. Isso, conforme se verá mais adiante, foi objeto de reflexão de diversos juristas e políticos brasileiros do século XIX.

Clavero afirma que o direito administrativo, assim como a codificação foram criaturas revolucionárias, de viés napoleônico ${ }^{170}$. Em sua visão, codificação e direito administrativo sem códigos, constituem elementos diversos de um mesmo sistema. Lopes considera que retirar os assuntos político dos tribunais judiciários era um meio de permitir que as reformas fossem realizadas, uma vez que esses tribunais respeitavam as tradições e os privilégios. Essa separação, de acordo com o referido autor, se devia à

diferenças entre esses autores, sendo que o comum a eles é o uso da sintaxe do contrato para "racionalizar a força e alicerçar o poder no consenso. MATTEUCCI, N. Contratualismo in: BOBBIO, N. MATTEUCCI, N. PASQUINO, G. Dicionário de Política. Brasília, Editora UnB, 1998, p. 272-283.

${ }^{168}$ Segundo Guido Fassó, o jusnaturalismo é uma doutrina segundo a qual existe um direito natural, que pode ser conhecido e que constitui um sistema de normas de conduta intersubjetivas, que diferem do sistema de normas fixadas pelo Estado. Para Fassó, esse sistema é superior e anterior ao direito positivo, devendo ele prevalecer em caso de conflito. O termo jusnaturalismo diversas vezes é confundido com as teorias contratualistas dos séculos XVII e XVIII, como se fosse criação desse período, quando, na verdade suas origens remontam à antiguidade e à Idade Média. O autor destaca três vertentes do jusnaturalismo: uma que afirma a existência de uma lei estabelecida por vontade divina, e revelada aos homens pela mesma vontade; outra que defende que há uma lei natural "fisicamente co-natural a todos os seres animados à guisa de instinto"; e por fim, uma vertente que considera o direito natural como uma lei ditada pela razão, específica do ser humano que a encontraria de modo autônomo dentro de si. No século XVII, Hugo Grócio em sua obra De iure belli ac pacis de 1625 afirmou que o direito natural era independente da vontade de Deus e mesmo de sua existência. Essa idéia teve uma forte influência sobre o constitucionalismo, pois traz consigo a necessidade de adequar o direito positivo ao direito natural, assim como legitima a desobediência e a resistência às leis e Constituições que fossem opostas ao direito natural, o que encontrou forma na obra de John Locke. Diferentemente do jusnaturalismo medieval, uma característica importante do jusnaturalismo moderno é que o Estado aparece como criação dos indivíduos e não como uma instituição necessária por natureza. O jusnaturalismo no século XIX fez sentir sua influência nos processos de codificação, especialmente na França e na Prússia, onde procurou-se dar forma de legislação positiva ao direito natural. Para Fassó, o problema da reforma na França consistia em fazer com que as normas do direito natural se convertessem em normas positivas. FASSÓ, G. Jusnaturalismo in: : BOBBIO, N. MATTEUCCI, N. PASQUINO, G. Dicionário de Política ... op.cit. p. 655-660. Ver também: FASSÓ, G. História de La Filosofia Del Derecho. Madrid, Ediciónes Piramide, 1966. Sobre o processo de codificação na França ver o trabalho James Gordley sobre o Código Civil Francês: GORDLEY, J., Myths of the French Civil Code in: American Journal of Comparative Law, v. XLII, 3, p. 459-505, 1994.

${ }^{169}$ LOPES, J.R.L. As Palavras e a Lei... op.cit. p.236.

${ }^{170}$ CLAVERO, B. Happy Constitution ... op.cit. p. 202. 
desaprovação que os franceses tinham em relação aos seus tribunais judiciários, que, eram comumente associados à ideologias contra-revolucionárias ${ }^{171}$. Os códigos, segundo Clavero, implantam as leis que regulam a justiça, estabelecem seus procedimentos, sem, contudo, deixar-lhe espaço autônomo. Essa justiça tem sua competência limitada pela ação de outros poderes como o Legislativo, que define o teor dos códigos, e o Executivo, que se apresenta como Poder Governativo e Poder Administrativo. Estes dois últimos, segundo Clavero, encontram uma ampla autonomia, sem estarem sujeitos à fiscalização dos tribunais judiciários. Clavero afirma que dentro da concepção de direito administrativo de Dicey, a administração é um poder político com jurisdição autônoma que escapa à lei e à justiça e que não se deve a direitos ${ }^{172}$. Clavero também destaca que o poder governativo e administrativo encontra-se excluído domínio da lei que a codificação implica. Ou seja, o direito administrativo colocava a administração em uma posição na qual, no limite, respondia a ela mesma.

Para Lopes, a distinção entre interesses gerais e direitos particulares era clara entre os autores brasileiros do século XIX quando precisavam distinguir a esfera do contencioso administrativo ${ }^{173}$. Quando o conflito se dava entre interesses ou interesse e direito, no sistema jurídico do Império do Brasil, a questão era deslocada para o contencioso administrativo. Conforme o autor, essa distinção deitava raízes no surgimento do Direito Administrativo francês. Uma vez no período pré-revolucionário, os tribunais mantinham certa autonomia perante o poder real, com a revolução essa prática se tornou um problema, dada a resistência dos tribunais às reformas em curso. Assim, viu-se a necessidade de retirar as questões políticas da alçada dos tribunais judiciais e de se criar uma nova jurisdição, a administrativa ${ }^{174}$. Com isso, afirma Lopes, a justiça distributiva saiu das introduções dos cursos de direito civil do século XIX, que passaram a se ocupar especificamente dos direitos individuais. Nesse contexto, veio a se constituir o novo campo do Direito Público, representante dos interesses gerais, materializados no Estado, sendo esse interesse geral considerado superior aos interesses

\footnotetext{
${ }^{171}$ LOPES, J.R.L. As Palavras e a Lei ... op.cit. p.232.

${ }^{172}$ CLAVERO, B. Happy Constitution ... op.cit. p. 203.

${ }^{173}$ LOPES, J.R.L. As Palavras e a Lei ... op.cit.. p. 240.

${ }^{174}$ LOPES, J.R.L. As Palavras e a Lei ... op.cit.. p. 234.
} 
particulares $^{175}$. Disso, Lopes considera que o Direito Administrativo refere-se à questões de interesse geral, o que, em sua visão disciplina as relações entre o Estado e o cidadão ${ }^{176}$. Para o referido autor, a diferença entre direitos e interesses é assim fundamental para a compreensão do Direito Administrativo, pois ele acaba se constituindo como um campo no qual há espaço para considerações a respeito do interesse, ao contrário do direito privado, no qual há lugar apenas para os direitos individuais bilaterais ${ }^{177}$.

Mesmo no campo do Direito Administrativo, havia uma distinção essencial para os autores brasileiros do século XIX, aquela entre administração contenciosa e administração graciosa. A administração graciosa diz respeito aos interesses particulares, e a administração contenciosa diz respeito a direitos, garantidos por lei. Contudo, ambas estão na órbita do Direito Administrativo quando se confrontam com o interesse geral. Ao discutir as competências do Poder Judiciário e do Poder Executivo, Antonio Joaquim Ribas, professor de Direito Administrativo na Academia de São Paulo $^{178}$, desde 1855, já se valia da distinção entre direitos e interesses. Em sua obra, Direito Administrativo Brasileiro: Noções Preliminares, aprovada para uso nos curós jurídicos em 1861 e publicada em 1866, postulava que a administração se ocupava das leis de interesse geral, e tinha por incumbência curar as necessidades gerais ou coletivas; enquanto o Poder Judicial se ocupava com as leis de interesse privado, cabendo a ele defender os direitos individuais dos cidadãos ${ }^{179}$.

Assim, os publicistas brasileiros do século XIX consideravam que a existência do contencioso administrativo justificava-se não por questões de expediente, mas por arbitrar conflitos de natureza diferente daquelas para as quais estava habilitado o Poder

\footnotetext{
${ }^{175}$ LOPES, J.R.L. As Palavras e a Lei ... op.cit.. p. 234-235.

${ }^{176}$ LOPES, J.R.L. As Palavras e a Lei ... op.cit.. p. 237.

${ }^{177}$ LOPES, J.R.L. As Palavras e a Lei ... op.cit.. p. 237-238.

178 Ribas afirma que o Direito Administrativo como disciplina dos cursos de direito foi criação francesa pós-napoleônica, sendo uma realização do governo de Luiz XVIII, que criou uma cadeira de Direito Administrativo na escola de direito de Paris. Para isso, foi nomeado Joseph Marie de Gérando, Barão de Gérando, filósofo e jurista francês de inaugurar o ensino da nova disciplina. Todavia, o contexto político da França da restauração fez com que o empreendimento fosse barrado. Contudo, em 1828, de Gérando teve permissão para ir adiante e restaurar a cadeira suprimida. Nessa ocasião, segundo Ribas, reuniu mais de 80.000 textos de leis e regulamentos, de onde saiu sua obra Institutes du droit administratif français, ou Éléments du code administratif, réunis et mis en ordre, publicado em 6 volumes entre 1829 e 1836. RIBAS, A.J. Direito Administrativo Brasileiro ... op.cit. p. 9-11.

${ }^{179}$ RIBAS, A.J. op.cit. p.166-167.
} 
Judiciário; sendo então, uma forma de resguardar a independência dos poderes. Ribas afirmava que administração por vezes atuava como poder político, incumbido de velar sobre o interesse geral. Em outras ocasiões, funcionava como representante da pessoa jurídica do Estado, que, equiparava-se às pessoas físicas no tocante aos direitos patrimoniais. Para o professor da Academia de Direito, o contencioso administrativo tinha lugar no primeiro caso, ou seja, quando se invoca a ação da administração, considerada poder político, ou "se recorre de ato por ela praticado sob este mesmo caráter”. Já no segundo caso, a questão deveria ser arbitrada pelos tribunais judiciários, pois se trataria de uma questão de trocas bilaterais entre duas pessoas jurídicas ${ }^{180}$. Ribas considerava que caso o administrador, cada vez que se encontrasse na execução de suas tarefas, se deparasse com uma pretensão que se dizesse fundada em direito, era necessário suspender a sua ação e sujeitar a resolução da questão a outra autoridade, "ver-se-ia a cada passo tolhido no desenvolvimento de sua atividade, e correriam graves riscos a prosperidade e a própria conservação da sociedade" ${ }^{181}$.

Segundo Ribas, a inauguração do sistema constitucional representativo no Brasil dera nova tendência ao espírito dos legisladores. Houve, na visão de Ribas, um entendimento de que seria necessário separar e distribuir por diversas autoridades as funções que os extintos tribunais reinóis exerciam. Contudo, Ribas apontava que a princípio confundiu-se o contencioso administrativo com o contencioso judiciário, colocando ambos como competência do Poder Judiciário, devendo ele intervir tanto em contendas entre particulares como em pleitos entre particulares e a administração ${ }^{182}$.

Ribas afirma que a reação a essa incorporação do contencioso administrativo pelo Poder Judiciário começou com a Provisão de 24 de outubro de $1834^{183}$ e de modo mais amplo pela Lei $n^{\circ} 234$ de 23 de outubro de 1841, que recriou o Conselho de

\footnotetext{
${ }^{180}$ RIBAS, A.J. Direito Administrativo Brasileiro: Noções Preliminares. (Obra premiada e aprovada pela Resolução Imperial de 9 de fevereiro de 1861 para uso das aulas das Faculdades de Direito de Recife e São Paulo). Rio de Janeiro, F.L. Pinto \& C. Livreiros-Editores 87, 1866, p.167 Disponível em: www.stj.jus.br/bdjur.

${ }^{181}$ RIBAS, A.J. Direito Administrativo Brasileiro ... op.cit. p.160.

${ }^{182}$ RIBAS, A.J. Direito Administrativo Brasileiro ... op.cit. p.146.

${ }^{183}$ Ribas afirma que essa Provisão veio firmar a "então contestada jurisdição do thesouro e thesouraruas sobre o contencioso administrativo, anteriormente exercida pelo erário e o tribunal do Conselho da Fazenda." RIBAS, A.J. Direito Administrativo Brasileiro ... op.cit. p.149.
} 
Estado (regulamentando em 5 de fevereiro de 1842) e na Lei de 3 de dezembro de $1841^{184}$ e respectivos regulamentos.

No Brasil, os cursos jurídicos criados pela Lei de 11 de agosto de 1827 não contemplavam, a princípio, o ensino do Direito Administrativo. Contudo, Ribas afirma que a primeira vez que a idéia de criar uma cadeira de Direito Administrativo nos cursos de São Paulo e do Recife surgiu em 1833 no relatório do ministro do Império, Nicolau de Campos Vergueiro. Somente no chamado gabinete Olinda-Monte Alegre, no ano de 1851, que a Assembléia Geral autorizou a criação da cadeira de Direito Administrativo nos cursos jurídicos do Império, sendo então estabelecidas pelo Decreto n 608 de 16 de Agosto de 1851, que também criou cadeiras de Direito Romano. Três anos depois, sendo ministro do império o Sr. conselheiro L. P. do Couto Ferraz, foram decretados novos estatutos aos cursos jurídicos (Decreto no 1386 de 28 de Abril de 1854), e em 1855 Ribas iniciou as aulas sobre essa matéria no curso jurídico de São Paulo $^{185}$.

Dalmo de Abreu Dallari indica que o artigo $7^{\circ}$ da lei de 23 de outubro de 1841, deu ao Conselho de Estado a condição de um verdadeiro contencioso administrativo ${ }^{186}$. Embora as decisões coubessem ao monarca, ele em geral acatava o parecer dos conselheiros $^{187}$. O Regulamento do Conselho de Estado, de 1842, estabeleceu em seu Capítulo III, "Dos Objetos Contenciosos" (artigos 24 a 51) a institucionalização do contencioso administrativo.

$\mathrm{O}$ art. 24 do Regulamento estabelecia que caso o Presidente da Província ou o Procurador da Coroa tivessem notícia de que havia autoridade judiciária tomando

\footnotetext{
${ }^{184}$ Segundo Ribas, a Lei de 3 de dezembro destacara do Poder Judiciário diversas atribuições em matéria criminal, transferindo-as para autoridades policiais e administrativas. RIBAS, A.J. Direito Administrativo Brasileiro ... op.cit. p. 149-150.

${ }^{185}$ RIBAS, A.J. Direito Administrativo Brasileiro ... op.cit. p. 9-11.

${ }^{186} \mathrm{O}$ art. $7^{\circ}$ estabelecia os negócios principais sobre os quais o Imperador poderia, caso considerasse conveniente, consultar o Conselho de Estado: quando fosse utilizar o Poder Moderador nos casos previstos pelo art. 101 da Constituição; declarações de guerra e paz, assim como negociações com outros países; questões relacionadas a presas e indenizações; conflitos de jurisdição entre as autoridades administrativas e, entre essas e as autoridades judiciárias; abusos das autoridades eclesiásticas; e sobre assuntos relativos à execução das leis por parte do Poder Executivo, bem como projetos encaminhados por esse poder para a Assembléia Geral. In: BONAVIDES, P., AMARAL, R., Textos Políticos da História do Brasil. Brasília, Senado Federal, 2002, p.p. 95-100.

${ }^{187}$ DALLARI, D.A. O Conselho de Estado e o Contencioso Administrativo no Brasil. In: Revista de Direito Público. São Paulo, Editora Revista dos Tribunais, 1970, Janeiro/Março, Volume 11, p.37.
} 
conhecimento de algum objeto administrativo, deveria exigir dela esclarecimentos, assim como as razões pelas quais se julgava com jurisdição sobre aquele objeto. Caso o Presidente da Província julgasse improcedentes as razões dadas pela autoridade judiciária, ordenaria a cessação do procedimento judicial e mandaria citar os interessados para que dentro de um determinado prazo deduzissem seus direitos. Uma vez esgotado esse prazo, e o presidente entendendo o negócio como administrativo, resolveria por si provisoriamente, remetendo os papéis, junto com sua decisão ao Ministério da Justiça. Se a matéria não fosse considerada administrativa, o Presidente da Província ou o Procurador da Coroa ordenaria que continuasse o trâmite no foro judicial (artigos 25 e 26). Ao receber os papéis encaminhados pelos Presidentes ou pelo Procurador da Coroa, o ministro da Justiça deveria consultar a respectiva seção do Conselho de Estado, que, caso julgasse conveniente, ouviria as partes e emitiria seu parecer (art.27). Além disso, o regulamento determinava que as questões relativas aos apresamentos de navios envolvidos no comércio de africanos deveriam ser julgadas pelo governo em primeira e segunda instância (art.32).

Quando um caso chegava ao Conselho, ele era obrigado a ouvir o Procurador da Coroa, que no âmbito do processo administrativo exercia funções semelhantes às do promotor na justiça comum. O Regulamento também fixava normas para o processo administrativo. Pelo art. 33, a parte apresentaria a petição na respectiva secretaria de Estado, juntamente com os documentos pelos quais pretendesse justificar sua intenção. No caso de a petição ser considerada atendível, a seção do Conselho de Estado correspondente intimaria os interessados para que fossem ouvidos (art.34). A seção era autorizada a requerer todas as diligências que julgasse necessárias (art.35). Após proceder às diligências, a seção deveria apresentar um relatório, cujo conteúdo as partes poderiam tomar conhecimento por intermédio de seus advogados, havendo inclusive a possibilidade de fazer reparos para retificá-lo (art.36). O Regulamento também estabelecia que haveria até dez advogados do Conselho de Estado, que seriam os únicos com capacidade postulatória para representar as partes perante o Conselho, bem como assistir às diligências que fossem necessárias ao processo. Por fim, o art.41 do Regulamento estabelecia os dois casos em que poderia haver suspensão do processo: morte da parte, morte ou impossibilidade do advogado para exercer suas funções antes 
do último relatório da seção; ou ainda quando algum documento ou testemunha fosse argüido como falso.

Vicente Pereira do Rego, professor de Direito Administrativo da Academia de Direito do Recife, na mesma época em que Ribas respondia pela cadeira em São Paulo, considerava que o Conselho de Estado possuía a plenitude da jurisdição administrativa, sendo, a seu ver, um tribunal de apelação, pois suas atribuições equivaliam às de "Supremo Tribunal de Justiça Administrativa". Essa formulação era justificada pelo autor devido ao fato de competir ao Conselho de Estado a anulação das decisões do Tribunal do Tesouro e dos chefes das repartições fiscais nos casos de incompetência, excesso de poder ou violação da lei ${ }^{188}$. Tal atribuição possui grande importância para a discussão a respeito do contencioso administrativo que se desenvolveu no segundo reinado, pois muitos de seus defensores, como o próprio Visconde do Uruguai, queixavam-se do fato de não haver uma organização definida do contencioso administrativo em primeira e segunda instância, sendo isso realidade somente no âmbito da Fazenda. O Regulamento do Conselho de Estado institucionalizava o contencioso administrativo e estabelecia a forma do processo perante o Conselho. Todavia, não estabelecia como seria, no âmbito dos diversos ministérios, a forma do processo em primeira e segunda instância, antes de chegarem até ele. Com isso, em grande parte dos casos, os Presidentes de Província decidiam sozinhos as matérias contenciosas que então obrigatoriamente eram remetidas ao ministério, que provocava a respectiva Seção do Conselho de Estado a se manifestar.

Considerando os procedimentos relativos ao Tesouro e às repartições fiscais, Lopes afirma que a organização do contencioso administrativo no âmbito da Fazenda

188 REGO, V.P. Elementos de Direito Administrativo Brasileiro, Para Uso nas Faculdades de Direito do Império. Recife, Typographia Commercial de Geraldo Henrique e Mira \& C. 1860, p. 109-112. Conforme aponta Rego, o Tribunal do Tesouro Nacional fora creido pelo art. 170 da Constituição do Império, sendo organizado e regulado pela Lei de 4 de outubro de 1831. Sua principal atribuição era a de regular e fiscalizar as contas públicas. Contudo, adquiriu forma organizada de contencioso administrativo com os Decretos no 736 de 20 de Novembro de 1850, e no 2343 de 29 de Janeiro de 1859. Esses decretos davam ao Tribunal de Tesouro a seguinte organização: a Secretaria de Estado dos Negócios da Fazenda, com sua Diretoria Geral do Contencioso; a Diretoria Geral das Rendas Públicas; a Dita da Tomada de Contas ; a Dita da Contabilidade; a Dita do Contencioso; a Tesouraria Geral, duas pagadorias, e um cartório. Das decisões do Tribunal do Tesouro cabia recurso ao Conselho de Estado nos casos de incompetência, excesso de poder, violação de Lei, e preterição de formulas consideradas essenciais. REGO, V.P. Elementos ... op.cit. p. 99-108. 
era a forma mais explícita de contencioso administrativo no Império ${ }^{189}$.Já Lydia Garner pondera que para a implementação das decisões do poder Executivo era necessário que este poder, e não o Judiciário, tivesse a competência de decidir acerca de assuntos sob sua jurisdição ${ }^{190}$. Do contrario, haveria o risco do Judiciário interferir nos atos da administração; o que de fato, em muitos assuntos, ocorria. Mesmo a reforma do Código de Processo Criminal, que concentrou o aparato judiciário nas mãos do governo central, não garantia que ele conseguisse implementar suas decisões sem negociar com as elites provinciais e locais, pois entre outras coisas, as mesas eleitorais mantiveram-se sob o controle das autoridades eleitas localmente ${ }^{191}$. Assim, o estabelecimento do sistema do contencioso administrativo, garantia ao Rio de Janeiro a palavra final em contendas nas quais estivesse envolvido; em outras palavras, o poder central seria seu próprio juiz. Para Garner, uma vez estabelecida essa autoridade administrativa, constituiria ela verdadeira pedra angular no edifício da centralização política. Analisando a Seção dos Negócios do Império do Conselho de Estado, a autora afirma que a Seção permitia ao ministério um senso de continuidade e estabilidade, que não poderia possuir caso houvesse a interferência de outro poder. Garner também considera que esse sistema permitia manter sob controle o poder discricionário dos membros dos gabinetes, ao ser permitido apelar de suas decisões ao Conselho de Estado ${ }^{192}$. Todavia, esse senso de continuidade mencionado por Garner é passível de contestação. Os defensores do contencioso administrativo, como Uruguai e Pimenta Bueno reclamavam justamente do fato de não haver uma organização e nem um senso de continuidade. Segundo Uruguai, "passados tempos aparece a mesma questão ou análoga questão. Supõe-se nova; tratase dela como se aparecesse pela primeira vez, e decidi-se às vezes contraditoriamente" $" 193$.

\footnotetext{
${ }^{189}$ LOPES, J.R.L.O Oráculo de Delfos ... op.cit. p.159, nota 138.

${ }^{190}$ GARNER, Lydia, Justiça Administrativa no Brasil Império (1842-1889), XX International Congress, Latin American Studies Association. Guadalajara, México, 1997, p.2.

${ }^{191}$ Conforme tratado no Capítulo 1, Miriam Dohlnikoff demonstra que a mesa eleitoral era soberana, podendo inclusive contestar a identidade dos votantes. DOHLNIKOFF, M. O Pacto Imperial: Origens do Federalismo no Brasil. São Paulo, Editora Globo, 2005, p. 108.

${ }^{192}$ GARNER, L., "In Pursuit of Order: The Section of Empire of the Council of State, 1842-1889." Tese de doutoramento, The Johns Hopkins University, 1987, p. 507.

${ }^{193}$ URUGUAI, V. Ensaio Sobre o Direito Administrativo. in: CARVALHO, J.M. (ORG), Visconde do Uruguai. São Paulo, Editora 34, 2002, p. 299.
} 
Além de, na prática ser o tribunal supremo do contencioso administrativo, grande parte do trabalho das Seções do Conselho de Estado era o de julgar conflitos entre os cidadãos e administração ou, ainda, conflitos internos da própria administração. Muitas destas consultas, além de serem provocadas por Avisos, também davam origem a outros Avisos. José Reinaldo de Lima Lopes considera que os Avisos funcionavam como verdadeiras interpretações autênticas dos regulamentos gerais e, parecendo ter força de lei geral mesmo que não fossem redigidos sob a forma de articulados normativos, eram dados a conhecer de modo público e muitas vezes se assemelhavam a circulares ${ }^{194}$. Contudo, não chegavam a ter o impacto de uma lei geral, pois não havia uma uniformização da jurisprudência administrativa.

Assim, Lopes considera que se formou uma cultura jurídica a partir do Conselho de Estado, da qual os Avisos são uma expressão. A partir do questionamento de que “Como pôde haver um Estado de bacharéis sem que houvesse uma cultura jurídica?"195, Lopes afirma que a cultura jurídica foi se formando a partir da prática cotidiana do aparelho do Estado, diferentemente de outros países como a Alemanha, na qual se constituiu uma cultura jurídica a partir da Universidade de Berlim. Comparando as duas realidades, Lopes considera que a tarefa que era de reforma e modernização na Europa, era praticamente a de invenção no Brasil. Nesse contexto, em sua visão, colocavam-se duas tarefas distintas aos juristas brasileiros do XIX, a de construção de um Estado Nacional, com um direito distinto daquele herdado de Portugal, e a de erguer um Estado constitucional liberal que substituísse o "velho municipalismo das Câmaras" pelo "novo ideário do Estado-Nação"196.

Lydia Garner afirma que no caso da Seção do Império, por ela estudada, a jurisprudência era reconhecida como lei, sendo que, com o passar dos anos, o acúmulo de decisões começou a formar um corpo de precedentes que eram citados como qualquer normatização judicial. Para ela, o Regulamento do Conselho de Estado de 1842 constituíra somente o primeiro passo de um longo trabalho de composição de um

\footnotetext{
194 LOPES, J.R.L.. In: Almanack Braziliense n5 maio/2007,p.11. GARNER, L. In Pursuit... op.cit. p. 492- 499.

${ }^{195}$ LOPES, J.R.L.O Oráculo de Delfos ... op.cit. p.111.

${ }^{196}$ LOPES, J.R.L.O Oráculo de Delfos ... op.cit. p.109.
} 
corpo de legislação pelas seções do Conselho de Estado ${ }^{197}$, até porque a formação de precedentes não foi privilégio da Seção do Império. Na Seção de Justiça isso também ocorria. Como exemplo, pode-se citar a Resolução de 28 de junho de 1854, na qual a Seção decidiu que o assassínio de um feitor escravo era semelhante ao de um feitor não-escravo, e, portanto, sujeito às mesmas penas. Anos mais tarde, em 1861, a Seção foi consultada sobre o mesmo assunto. Sua resposta foi curta e direta: "Esta consulta já obteve resolução imperial como parece. Uma resolução agora em sentido contrário seria uma reforma do que já foi decidido"198. Vale aqui lembrar, que, como não havia uma Secretaria do Conselho de Estado, as consultas de cada uma das Seções, ficava a cargo do Ministério que as provocava. Isso, conforme se verá, era algo que descontentava Uruguai, pois dificultava, a seu ver, a formação de uma jurisprudência administrativa.

Segundo o entendimento de Lopes, a lei que regulamentou os recursos do Tribunal do Tesouro e a chamada Lei Euzébio de Queiroz (Lei no 581 de 4 de setembro de 1850) tinham por finalidade transformar o Conselho de Estado em "verdadeiro tribunal". As presas da repressão ao tráfico de escravos, segundo a lei, eram julgadas pela Auditoria da Marinha em primeira instância, com recurso obrigatório ao Conselho de Estado ${ }^{199}$. Isso gerou uma série de controvérsias a respeito do papel do Conselho de Estado, se deveria ser somente consultivo, ou se também deliberativo quanto a essas questões. Lopes aponta que o Conselho sempre hesitou em se assumir como órgão deliberativo, firmando-se sempre como consultivo ${ }^{200}$. Justamente em função das controvérsias geradas quer pelo papel do Conselho de Estado, quer pelas indefinições a respeito do contencioso administrativo, Uruguai elaborou, ainda que sob encomenda, seu projeto de organização da justiça administrativa.

\footnotetext{
${ }^{197}$ GARNER, L. In Pursuit... op.cit. p. 492- 499.

198 CAROATÁ, J.P.J.S. Imperiaes Resoluções Tomadas Sobre Consultas da Seção de Justiça do Conselho de Estado. Rio de Janeiro : B L Garnier, 1884, p.941. Esse caso foi citado apenas a título de exemplo. No Capítulo 4 será feito um exame mais detido sobre como as questões relativas à escravidão eram apreciadas pela Seção de Justiça e Negócios Estrangeiros do Conselho de Estado.

${ }^{199}$ LOPES, J.R.L.O Oráculo de Delfos ... op.cit. p.161.

${ }^{200}$ LOPES, J.R.L.O Oráculo de Delfos ... op.cit. p.p.206-207.
} 


\section{2 - A Proposta de Uruguai Para a Organização do Contencioso} Administrativo.

Conforme mencionado no início do capítulo, nas Bases Para Melhor Organização das Administrações Provinciais Uruguai teve de responder a diversos quesitos a respeito de questões relativas ao contencioso administrativo, estruturando de forma acabada seu pensamento acerca de sua organização. Os temas abordados nas Bases foram retomados e aprofundados no Ensaio. Juntos, esses trabalhos constituem o projeto de Uruguai para a organização das instituições administrativas.

O marquês de Olinda, então presidente do Conselho de Ministros, por Aviso de 19 de agosto de 1857, criou a comissão encarregada da "elaboração de um projeto para melhor organização das administrações provinciais, assentando-o sobre as bases mais convenientes, afim de que sejam estas administrações acompanhadas de instituições que não só as auxiliem com o seu conselho, por ocasião de tomarem decisões sobre interesses graves e na solução de questões práticas importantes, como também ajudem a autoridade nos lugares mais distantes das sedes dos governos provinciais" ${ }^{201}$ Uruguai ficou incumbido de formular as bases que serviriam de ponto de partida para a discussão, tratando de diversos temas como o contencioso e a centralização política; pois, como colocado acima, o contencioso administrativo do Império ainda que institucionalizado pelo Regulamento do Conselho de Estado, não tinha forma definida, salvo nos casos do Tribunal do Tesouro.

No mesmo ano do Aviso de 17 de agosto, Pimenta Bueno publicou o Direito Público e Análise da Constituição do Império ${ }^{202}$, obra na qual discute importantes temas do referido Aviso como a criação de Conselhos de Presidência $^{203}$ e a criação de agentes dos Presidentes de Província ${ }^{204}$.

\footnotetext{
${ }^{201}$ URUGUAI, V. Bases Para Melhor Organização das Administrações Provinciais. Rio de Janeiro, Typografia Nacional, 1958, p.1.

${ }^{202}$ Para uma visão mais aprofundada da intertextualidade das obras de Uruguai e Pimenta Bueno ver: MIGNONZZETTI, U.G. A Apropriação de Modelos Estrangeiros Pelo Pensamento Brasileiro: os Casos de Bernardo Pereira de Vasconcelos, Marquês de São Vicente e Visconde do Uruguai. São Paulo, Dissertação de Mestrado apresentada ao Programa de Pós-Graduação em Ciência Política da Universidade de São Paulo, 2009.

${ }^{203}$ A Constituição de 1824 previa que haveria Conselhos Gerais de Província de caráter eletivo. Com o Ato Adicional, esses Conselhos foram transformados em Assembléias Legislativas Provinciais. Antes
} 
Para ele, "a existência de um Conselho de Presidência livremente nomeado pelo governo central, e puramente consultivo é de manifesta conveniência”. Esses Conselhos, além de se tornarem depositários dos debates e das informações locais, também deveriam ser, para Pimenta Bueno, responsáveis pela instrução e julgamento de casos do contencioso administrativo, com recurso ao Conselho de Estado ${ }^{205}$. Outro ponto importante para Pimenta Bueno, era o fato de o Conselho de Estado não possuir uma Seção responsável pelo contencioso administrativo ${ }^{206}$.

Pimenta Bueno considera que do mesmo modo que o governo central necessitava de seus agentes nas Províncias, os Presidentes também necessitavam de agentes nas localidades. Em sua visão:

O Poder Administrativo ${ }^{207}$ deve, por meio de suas ramificações, estar presente em todas as partes do Estado, por isso mesmo que em toda a parte ele deve providenciar sobre a ordem pública, estudar todas as necessidades, e ocorrer com as medidas adequadas. É uma das graves lacunas da referida lei das presidências a de não ministrar à primeira autoridade, ao centro administrativo da Província, delegados do mesmo poder que coadjuvem sua ação. ${ }^{208}$

Uruguai, respondendo aos quesitos formulados por Olinda, afirmava que não conhecíamos o contencioso administrativo devido ao fato de a legislação não separá-lo

ainda da Constituição, foram criados por Lei de 20 de outubro de 1823 Conselhos de Presidência nas Províncias. Conforme Monica Dantas, o art. 10 da referida Lei estabelecia que cada Conselho seria composto por seis membros, eleitos do mesmo modo que os deputados à Assembléia Constituinte,sendo que o mais votado seria o Vice-Presidente. Nas matérias de competência do Conselho, ele teria voto deliberativo. Dantas ainda aponta que o art. 24 da Lei de 20 de outubro determinava as matérias que deveriam ser tratadas pelo "Presidente em Conselho". Entre elas estavam a proposição do estabelecimento de Câmaras onde não as houvesse, a suspensão dos Magistrados (conforme art. 34 da referida Lei) e suspensão dos Comandantes Militares. Segundo Dantas, os Presidentes em Conselho poderiam a partir de listas tríplice escolher os Juízes Municipais, de Órfãos, e os Promotores, além de escolher dentre os Magistrados quais deles seriam Juízes de Direito e do Cível. Após a aprovação do Ato Adicional, foi aprovada a Lei $\mathrm{n}^{\circ} 40$ de 3 de outubro de 1834, que extinguiu os Conselhos de Presidência passando, segundo seu art.12 as funções outrora exercidas pelo Presidente em Conselho a serem exercidas somente pelo Presidente. DANTAS, M.D. "O código do processo criminal e a reforma de 1841: dois modelos de organização do Estado (e suas instâncias de negociação)”. Conferência apresentada junto ao IV Congresso do Instituto Brasileiro de História do Direito - Autonomia do direito: configurações do jurídico entre a política e a sociedade, São Paulo, Faculdade de Direito/ USP, 2009, p. 6-9. Sobre os Conselhos ver também: SLEMIAN, A. Sob o império das leis: constituição e unidade nacional na formação do Brasil (1822-1834). São Paulo, Tese de Doutorado, FFLCH/USP, 2006.

${ }^{204}$ PIMENTA BUENO, J. A. Direito Público Brasileiro e Análise da Constituição do Império. In: KUGELMAS, E. Marquês de São Vicente. São Paulo, Editora 34, 2002, p.380-396.

${ }^{205}$ PIMENTA BUENO, J. A. Direito Público...op.cit. p. 396.

${ }^{206}$ PIMENTA BUENO, J. A. Direito Público...op.cit. p. 380-381.

${ }^{207}$ Conforme será discutido no próximo item, Pimenta Bueno considera o Poder Administrativo como ramo do Poder Executivo.

${ }^{208}$ PIMENTA BUENO, J. A. Direito Público...op.cit. p. 397. 
da administração pura. No sistema brasileiro, todas as decisões e julgamentos, que em outros países pertenciam à jurisdição do contencioso administrativo, ficavam a cargo de apenas uma pessoa, ou seja, o presidente da Província ${ }^{209}$, que, sem auxiliares, decidia sozinho as causas administrativas (artigos 24 a 26 do Regulamento de 5 de fevereiro de 1842). Uruguai cita como o exemplo o caso de um particular que contrata com a administração provincial a execução de uma obra. O particular gasta capitais na obra e não recebe o pagamento porque o Presidente da Província considera que diversas condições que a obra deveria preencher não foram alcançadas, ou seja, a obra não cumpriu o seu fim. Isso, Uruguai considerava um caso típico de contencioso administrativo, ou seja, o conflito do direito de um particular com o interesse geral $^{210}$. Pelo modo que o contencioso administrativo encontrava-se organizado, quem decidiria sobre tal caso seria somente o presidente. Após expor suas razões para a criação dos conselhos de presidência, Uruguai critica a falta de organização de primeira e segunda instância para o contencioso administrativo no Brasil, em contraposição a Portugal, onde o Conselho de Estado possuía uma Seção encarregada disto.

Quem o profere? O Presidente da Província único e só, sem ser ao menos obrigado a ouvir conselho. Não são requeridas formalidades algumas para a sua decisão.

Dir-se-á que o Regulamento do Conselho de Estado, art. 45 dá recurso das resoluções dos Presidentes das Províncias em negócios contenciosos para o Conselho de Estado. Mas o que são esses negócios contenciosos? Onde estão eles definidos na nossa legislação? Onde estão declaradas as suas principais feições? Serão aqueles, muito poucos, de que fala o citado regulamento? E por ventura compreende aquele art. 45 os negócios puramente provinciais? Todo esse importantíssimo assunto está em um verdadeiro estado de embrião.

Seja porém o que for semelhante recurso não pode, nem deve dispensar certas garantias e formalidades na $\mathbf{1}^{\mathrm{a}}$ instância.

Esses negócios são às vezes levados às Assembléias Provinciais e ao Poder Judiciário. As Assembléias Provinciais porém não são tribunais administrativos, nem podem aplicar, senão nos casos expressos no Ato Adicional, a lei aos fatos

Infelizmente a confusão em que está a nossa legislação, que apenas estabelece com mais alguma clareza o contencioso nos negócios da fazenda, dá lugar a que questões administrativas sejam levadas aos tribunais judiciários, que assim são tornados superiores e segunda instância para decisões do governo. ${ }^{211}$

Segundo o Visconde do Uruguai, o Conselho de Estado brasileiro ainda estava em estado embrionário, deixado assim pela lei de sua de criação e respectivo

\footnotetext{
${ }^{209}$ URUGUAI, V. Bases ... op.cit.p.4.

${ }^{210}$ URUGUAI, V. Bases ... op.cit.p.9 [Grifo Meu].

${ }^{211}$ URUGUAI, V. Bases ... op.cit.p.9.
} 
regulamento. Em sua visão, estava organizado timidamente, por causa do medo que tinham os partidos de que pudesse se tornar um elemento de força nas mãos do outro ${ }^{212}$. Para Uruguai, o contencioso administrativo no Brasil trabalhava sem direção, sem apurar e acumular tradições, não prestando à nossa organização e direito administrativo os serviços que poderia ter-lhes prestado. Situação expressa na falta de organização de um corpo de jurisprudência administrativa, em consequiência da pouca divulgação que tinham os pareceres das Seções do Conselho de Estado, o que fazia com que a mesma questão aparecesse mais de uma vez, sendo inclusive dadas soluções diferentes.

O caso citado no sub-capítulo acima, acerca das penas a serem imputadas no caso de assassínio de feitor escravo, mereceu crítica dos conselheiros quando tiveram que reapreciar, em 1861, uma questão já resolvida por eles em 1855. A dúvida de 1861 provinha do Juiz Municipal de Rio Preto em Minas Gerais, dúvida que bem poderia ser real, em função da pouca divulgação dos pareceres.

De todas as Seções do Conselho de Estado, a única que não teve qualquer tipo de publicação foi a Seção do Império. No caso da Seção de Justiça e Negócios Estrangeiros, que nos interessa em especial, além das fontes manuscritas presentes no Arquivo Nacional no Rio de Janeiro, há diversas publicações, que foram, na época, os únicos meios possíveis de se fazer conhecer o teor das decisões. No caso das consultas oriundas do Ministério da Justiça: há a coletânea organizada por José Próspero Jeová da Silva Caroatá ${ }^{213}$, considerada por Lopes como a mais completa das fontes publicadas; a coletânea de Belarmino Braziliense Pessoa de Mello, que se refere somente aos anos de 1842 a 1846 (mas cuja publicação data de 1877) ${ }^{214}$; e a de Augusto de Tavares Lyra, publicada em $1907^{215}$. Os assuntos eclesiásticos foram tratados na Seção de Justiça e Estrangeiros até 1859, quando passaram à jurisdição do Ministério do Império, passando, conseqüentemente, a serem tratados na Seção dos Negócios do Império. Manoel Francisco Correa, funcionário do Ministério do Império, coligiu e publicou

\footnotetext{
${ }^{212}$ URUGUAI, V. Bases ... op.cit.p. 10

${ }^{213}$ CAROATÁ, J.P.J.S. Imperiaes Resoluções Tomadas Sobre Consultas da Seção de Justiça do Conselho de Estado. Rio de Janeiro : B L Garnier, 1884.

${ }^{214}$ MELLO, B.B.P. Imperiaes Resoluções Tomadas Sobre Consultas da Seção de Justiça do Conelho de Estado Desde o Anno em que Começou a Funcionar o Dito Conselho. Rio de Janeiro, Typographia Nacional, 1877.

${ }^{215}$ LYRA, A.T. Consultas do Extincto Conselho de Estado Sobre Assumptos de Competência do Ministério da Justiça. Rio de Janeiro, Imprensa Nacional, 1907.
} 
entre 1869 e 1870 três volumes com as consultas referentes aos negócios eclesiásticos compreendidas entre 1843 e 1870, ou seja, encontram-se nessa coletânea as consultas feitas quando estavam sob a alçada do Ministério da Justiça ${ }^{216}$. Quanto às fontes publicadas das consultas originárias do Ministério dos Negócios Estrangeiros, há a coletânea organizada entre 2005 e 2009 pela Fundação Alexandre de Gusmão (FUNAG), que compreende o período de 1858 a $1889^{217}$. No que diz respeito ao período anterior a 1858, há outra coletânea, organizada pela Câmara dos Deputados, que abrange o período de 1842 a $1889^{218}$.

Segundo Uruguai, "as consultas das seções do Conselho de Estado não tem a força e a importância que têm, por exemplo, na França" ${ }^{219}$, pois, a seu ver, a jurisprudência do contencioso administrativo no Brasil era acessível somente aos que tinham entrada nas secretarias e "coragem bastante para desempoeirar maços de papel enormes, onde tudo jaz sepultado no pó do esquecimento"220.

Para além disso, Uruguai, já no Ensaio, ponderava que a base do contencioso administrativo brasileiro tinha pouquíssima legislação emanada diretamente do Poder Legislativo, sendo que o contencioso administrativo brasileiro resultava então, em sua maior parte, de regulamentos feitos pelo próprio governo ${ }^{221}$. O Regulamento de 5 de

\footnotetext{
${ }^{216}$ CORREA, M.F., Consultas do Conselho de Estado Sobre Negócios Eclesiásticos. Rio de Janeiro, Typographia Nacional, 1869-1870. As fontes publicadas das consultas feitas a partir do Ministério da Justiça encontram-se disponíveis para consulta online em: www.brasiliana.usp.br

${ }^{217}$ BRASIL, Secretaria de Estado dos Negócios Estrangeiros, O Conselho de Estado e a Política Externa do Império: Consultas da Seção dos Negócios Estrangeiros: 1858-1889. Brasília, FUNAG, 2005 a 2009.

${ }^{218}$ BRASIL, Conselho de Estado (1842-1889), Consultas da Seção dos Negócios Estrangeiros. Brasília, Câmara dos Deputados, 1981. Além das fontes publicadas, há diversos documentos manuscritos em Códices no Arquivo Nacional no Rio de Janeiro. Essa documentação compreende documentos anexos que acompanhavam as consultas, Avisos Ministeriais de provocação da consulta, com a designação dos relatores, Livros de Protocolo, Juramentos dos Advogados do Conselho, Juramentos dos Conselheiros de Estado, entre outros documentos. Para uma discussão mais detida sobre as fontes da Seção de Justiça, assim como as discrepâncias entre as fontes publicadas e as manuscritas, ver: LOPES, J.R.L.O Oráculo de Delfos ... op.cit. p. 150-156.

${ }^{219}$ URUGUAI, V. Ensaio Sobre o Direito Administrativo. in: CARVALHO, J.M. (ORG), Visconde do Uruguai. São Paulo, Editora 34, 2002, p. 165.

${ }^{220}$ URUGUAI, V. Ensaio ... op.cit. p.165.

${ }^{221}$ O art. 8 da Lei de 23 de novembro de 1841 autorizava o governo a determinar por meio de regulamentos o número de Seções do Conselho de Estado, o modo de funcionamento e as demais medidas necessárias para a aplicação da referida Lei. O Regulamento de 5 de fevereiro deu a base para 0 contencioso administrativo do Império. A Lei no 563 de 4 de julho de 1850 deu ao governo a autorização para reformar o Tesouro público e as tesourarias provinciais, o que originou os Decretos $n^{\circ} 736$ de 20 de Novembro de 1850 , e $\mathrm{n}^{\circ} 2343$ de 29 de Janeiro de 1859, que deram organização ao contencioso administrativo no âmbito da Fazenda. BONAVIDES, P., AMARAL, R., Textos Políticos da História do Brasil. Brasília, Senado Federal, 2002, volume 8,p.p. 259-261.
} 
fevereiro, em sua opinião, dera jurisdição contenciosa administrativa aos ministros de Estado e Presidentes de Província, o que, para ele, respondia em grande parte pela desorganização do contencioso administrativo brasileiro, já que se baseava quase integralmente, em regulamentos do governo, sem uma lei específica que lhe servisse de pedra angular ${ }^{222}$.

E não conhecendo nós bem o contencioso administrativo, apesar de o termos (nem poderíamos deixar de tê-lo); não fazendo a nossa legislação distinção eficaz entre ele e o gracioso, de modo que tudo quanto não é judicial, é puramente discricionário, todas as decisões, ou, para melhor dizer, todos os julgamentos administrativos que, em outros países, por pertencerem ao contencioso, competem a tribunais administrativos, são entre nós decididos por um homem só, o presidente. ${ }^{223}$

Devido ao fato de os julgamentos do contencioso administrativo serem feitos nas Províncias unicamente pelos presidentes, Uruguai afirmava que a conseqüência era a total ausência de garantias processuais. Assim, caberia somente o recurso ao Conselho de Estado $^{224}$. Essas reflexões, Uruguai já havia feito em parte nas Bases, em que afirmava que as únicas bases da organização administrativa do país eram as províncias e os municípios. A legislação regulamentar não havia, a seu ver, preenchido as lacunas, dando o desenvolvimento que a organização administrativa demandava. Além disso, também não se havia separado devidamente a administração da justiça, o que seria puramente administrativo, do contencioso, pois não existiam autoridades auxiliares dos presidentes ${ }^{225}$. Conforme mencionamos no início do capítulo, um dos quesitos perguntados pelo "Aviso" era o da conveniência ou não da criação de Conselhos de Presidência nas Províncias, ao que, Uruguai respondeu a afirmativamente, defendendo que fossem de livre nomeação do Imperador.

Para o visconde, sendo o Presidente a primeira autoridade de uma província, com um variado número de atribuições importantes, e cujas decisões possuíam influência na felicidade e bem-estar dos administrados, ele deveria ter a quem pudesse ou em certos casos devesse pedir conselhos. Ademais, afirmava que, sendo o conselho bom, teria como benefício fazer sobressair o erro ou a prevaricação, tornando mais

\footnotetext{
${ }^{222}$ URUGUAI, V. Ensaio ... op.cit. p. 184-186.

${ }^{223}{ }^{223}$ URUGUAI, V. Ensaio ... op.cit. p. 210.

${ }^{224}$ URUGUAI, V. Ensaio ... op.cit. p.189.

${ }^{225}$ URUGUAI, V. Bases ... op.cit.p.3
} 
eficaz a responsabilidade quando o conselho não fosse seguido. Em sua opinião, sendo os conselhos bem compostos, poderiam eles ser um corretivo dos inconvenientes trazidos pela instabilidade e curta permanência dos presidentes, constituindo-se em depositários das tradições, e, deste modo, contribuindo para que as futuras administrações provinciais fossem dotadas de coerência e seguimento, que lamentava não terem. Por fim, afirmava que os conselhos eram uma garantia aos administradores na tomada de decisões das questões administrativas contenciosas ${ }^{226}$.

O segundo quesito sobre o qual perguntava o Aviso era de como organizar estes conselhos. Novamente, Uruguai lamentava a falta de organização das leis administrativas, e dizia que os membros dos conselhos deveriam ser imparciais para que a nova instituição não se tornasse arma política. Deveriam ser letrados, com tempo para empregar-se no estudos das leis administrativas e não deveriam ser membros do Poder Judiciário. Para ele, a organização dos conselhos encontraria grandes dificuldades, pois temia que a nomeação do conselheiro de presidência se tornasse negócio político, que fossem feitas visando a "satisfazer a vaidade, e para inculcar influência”. Uruguai defendia que deveria ser uma verdadeira magistratura administrativa, entregue ao exercício de suas funções. Disto, concluía que seria necessário, em grande número de casos, indicar para conselheiros de presidência pessoas de fora das províncias, que recebessem remuneração do governo, o que, a despeito de trazer o inconveniente de aumentar a despesa, poderia fazer destes conselhos "uma escola e um viveiro de administradores" 227 .

O Aviso também perguntava quais deveriam ser as funções dos Conselhos de Presidência e sobre quais matérias deveriam ser ouvidos. Para Uruguai seria necessário começar a fazer um ensaio desta instituição nas províncias onde a maior afluência de negócios administrativos a tornasse mais necessária, sendo fixada e estabelecida definitivamente depois que a experiência já a tivesse suficientemente ilustrado.

\footnotetext{
${ }^{226}$ URUGUAI, V. Bases ... op.cit.p.8

${ }^{227}$ URUGUAI, V. Bases ... op.cit.pp. 12-13. Esta última frase da citação é muito importante, se levarmos em conta a idéia que José Murilo de carvalho apresenta do Estado para Uruguai como pedagogo da liberdade. Entretanto, aqui é necessário atentar para o que diz Ilmar Rohloff de Mattos sobre a direção saquarema para entendermos o seu alcance. Segundo ele, os saquaremas não pretendiam substituir o governo da casa. O que objetivavam era estar em contato permanente com ele, rompendo seu isolacionismo para vigiá-lo e dirigi-lo. Ou seja, o Estado que educa o cidadão para a liberdade por meio de suas instituições o coloca em contato direto com ele, tem ali um aliado que pode tornar-se seu agente.
} 
Segundo o visconde, as funções desse conselho deveriam ser quase todas relativas às que exerciam os presidentes de províncias, além de outras que porventura a lei lhes confiasse. Assim, seria necessário fazer um apanhado, uma arrolamento de todas quantas atribuições exerciam os presidentes de província $^{228}$, pois:

Estão elas espalhadas por todo o corpo de nossas leis e regulamentos. Acham-se no Ato Adicional, na Lei de 3 de outubro de 1834, na de 1 de outubro de 1828, nas eleições, nas da Guarda Nacional, nas da fazenda, nas de organização judiciária, do Conselho de Estado e respectivos regulamentos, finalmente estão disseminadas por toda a parte, e em uma infinidade de leis provinciais. Coligidas e coordenadas todas essas atribuições, conviria classificá-las, segundo a sua natureza e importância; e instituir sobre cada uma acurado exame, para, segundo o que melhor parecer, regular as funções dos novos conselhos. $^{229}$

A partir destas considerações, Uruguai apresenta uma proposta concreta de mudança na organização do contencioso administrativo. Conforme sua proposta, o governo estabeleceria conselhos de presidência nas províncias onde uma maior afluência de negócios administrativos os pudesse tornar mais necessários. Esses conselhos seriam presididos pelo presidente da província e compostos por 3 a 5 membros, nomeados pelo Imperador, conservados enquanto bem servissem. Teriam preferência para a nomeação, pessoas habilitadas que residissem nas capitais das províncias, ou proximamente, e que servissem gratuitamente. Todavia, na falta de pessoas que atendessem a essa condição, poderiam ser nomeadas outras, concedendo-se a elas vencimentos. Não poderiam ser acumuladas tais funções com cargos do Poder Judiciário. As atribuições desses conselhos seriam meramente administrativas, e regidas por meio de regulamentos do governo com referência às atribuições de natureza também meramente administrativa que as leis em vigor conferiam aos presidentes de província. Também por meio de regulamentos o governo proveria sobre as suplências e sobre tudo quanto fosse necessário para que a instituição dos Conselhos de Presidência pudesse atingir seus objetivos. Por meio desses conselhos o governo organizaria o contencioso administrativo, fazendo alterações no regulamento do Conselho de Estado, criando-se uma Seção encarregada unicamente desta matéria. Segundo Uruguai, a

\footnotetext{
${ }^{228}$ URUGUAI, V. Bases ... op.cit. p.13-14.
}

${ }^{229}$ URUGUAI, V. Bases ... op.cit. p.13-14. 
experiência ilustraria o governo sobre estes assuntos. A partir disso, o governo proporia à Assembléia Geral Legislativa uma organização definitiva ${ }^{230}$.

No Ensaio Uruguai afirma que os Conselhos de Presidência criados pela Lei de 20 de outubro de 1823 não possuíam utilidade alguma, justamente por serem eletivos. Em sua visão:

Conselhos organizados por semelhante modo não podiam ser e não foram de utilidade alguma. Em épocas de partidos e de paixões políticas sobretudo, filhos de eleição popular ou estorvavam a marcha do Presidente, agente do Poder Executivo, ou serviam-lhe de escudo para se acobertar da responsabilidade, ou eram convocados, depois de tomada a medida, para desmoralizarem, se lhe eram avessos. ${ }^{231}$

Assim, Uruguai considerava que devido ao fato de terem sido uma instituição prática, positiva e aplicável, os Conselhos "não produziram fruto e caíram na nulidade". Contudo, a despeito das críticas, para Uruguai a extinção dos Conselhos de Presidência pela Lei de 3 de outubro de 1834, fora um erro, pois deveriam antes ter sido modificados, e não suprimidos. Daí, advém o problema que Uruguai considerava crucial, que era o da alta concentração de atribuições administrativas nas mãos dos Presidentes de Província, "às vezes novel, ao menos nos negócios locais, sem a assistência de conselho algum, sem o auxílio de agentes intermediários"232.

Também em razão do Aviso de 1857, Uruguai propôs a criação de agentes administrativos subordinados aos Presidentes de Província, tema que retomou posteriormente no Ensaio. O Aviso pedia também que se ponderasse da conveniência de tais autoridades, agindo segundo as instruções dos Presidentes, possuírem poder para resolverem por si negócios contenciosos, ficando a solução definitiva a cargo dos Presidentes. Ademais, perguntava se conviria determinar os casos em que os Presidentes poderiam delegar suas tarefas a estas autoridades, e se seria pertinente determinar os casos em que elas poderiam resolver por si. Por fim, questionava acerca do território onde essas autoridades poderiam exercer seu poder ${ }^{233}$.

Ao responder a estas questões, Uruguai afirma que os principais defeitos da lei de 3 de dezembro de 1841 provinham principalmente da falta de agentes

\footnotetext{
${ }^{230}$ URUGUAI, V. Bases ... op.cit.p. 14-15

${ }^{231}$ URUGUAI, V. Ensaio ... op.cit. p. 216.

${ }^{232}$ URUGUAI, V. Ensaio ... op.cit. p. 216.

${ }^{233}$ URUGUAI, V. Bases ... op.cit.p. 15
} 
administrativos nas localidade, aos quais pudessem ser confiadas certas atribuições que não eram propriamente judiciárias. Em sua opinião, a criação de comissários dos presidentes, em todos ou ao menos em certos distritos das províncias, tenderiam a encontrar praticamente as mesmas, senão maiores dificuldades, que os conselhos de presidência, especialmente se exercessem suas funções gratuitamente. Contudo, a despeito das dificuldades, Uruguai formula uma proposta concreta para a criação destes comissários nas localidades, que seriam uma espécie de juízes do contencioso administrativo, subordinados ao presidente da província.

Em sua opinião, a criação desses comissários deveria ser feita de modo ensaiado, assim como os conselhos. O governo criaria agentes auxiliares dos presidentes nas localidades mais distantes das capitais das províncias, ou naquelas em que a criação parecesse mais conveniente, mediante mapeamento dos distritos que poderiam compreender um ou mais municípios. O governo, por meio de regulamentos, especificaria quais os casos em que os comissários poderiam decidir por si, podendo sempre sua decisão ser revogada ou reformada pelo Presidente da Província, que seria comunicado imediatamente da decisão de seu agente. Por regulamentos ainda seriam estabelecidos os casos em que os agentes poderiam decidir em virtude de comissão ou delegação do presidente, e de acordo com suas instruções. Além dos casos que viessem a ser previstos em regulamento, não poderia haver comissão ou delegação alguma.

Os comissários seriam provisoriamente nomeados pelo Presidente da Província, necessitando serem confirmados definitivamente por decreto imperial. Os comissários poderiam ser suspensos pelo Presidente da Província, que poderia também pedir a sua demissão ao governo central. Segundo Uruguai, teriam preferência para o preenchimento destes cargos pessoas idôneas, residentes no distrito e que se dispusessem a servir gratuitamente. Todavia, caso não fossem encontradas pessoas nestas condições, poderiam ser nomeadas outras, que receberiam vencimentos. O cargo de comissário, tal como o de conselheiro, seria incompatível com os cargos do Poder Judiciário. Além disso, o governo geral ficaria encarregado de prover mediante regulamentos as suplências, e o que mais fosse necessário para que a instituição dos comissários dos presidentes atingisse o seu fim. Após o acúmulo de experiência com os comissários, o governo proporia à Assembléia Geral Legislativa a organização 
definitiva desta instituição. Segundo Uruguai, “este projeto poderá ser refundido com o dos conselheiros de presidência, melhorando-se a redação. Dividi-os para responder separadamente aos quesitos postos, e porque tive mais em vista expor o meu pensamento do que um projeto definitivo, cuja organização pertence à comissão."234

Essa questão dos agentes administrativos foi por ele retomada no Ensaio, onde formula sua metáfora de que o grande defeito das administrações era o fato de possuir uma grande cabeça e praticamente não possuir nem braços e nem pernas. Segundo Uruguai, o Poder Executivo deveria preencher sua função administrativa por três instrumentos: agentes administrativos, conselhos administrativos e tribunais administrativos. Considerava que deveria existir no centro e nas grandes circunscrições territoriais agentes superiores que imprimem o movimento, ou seja, ditassem as regras, havendo nas subdivisões das grandes circunscrições uma série de agentes administrativos inferiores, cuja missão seria dar execução ao impulso recebido dos superiores $^{235}$.

Uruguai chama de agente administrativo direto aquele que está em contato com o chefe do Poder Executivo ou com seus ministros, ou seja, os Presidentes de Província e os próprios ministros. Os subordinados dos agentes diretos, que com eles estão em contato por meio de uma estrutura hierárquica são chamados por Uruguai de agentes auxiliares, cujo serviço pode ser tanto externo quanto interno ${ }^{236}$. O serviço interior é para Uruguai aquele realizado dentro das repartições, cuja função fosse "coordenar e preparar os atos da administração", sendo sua tarefa os "exames de papéis, redações, relatórios,expedição de ordens", entre outras atribuições ${ }^{237}$. O serviço exterior, em sua visão tinha por atribuição a realização das concepções elaboradas pelo serviço interior, enquadrando-se aqui o trabalho executado pelos agentes nas localidades.

A partir dessas definições, Uruguai afirma que sua metáfora da grande cabeça se deve ao fato de que havia uma enorme disparidade entre o serviço interno e o serviço externo das repartições. "Temos infelizmente grande tendência para o aparato". Para Uruguai as províncias eram "corpos cuja circulação não chega às suas

\footnotetext{
${ }^{234}$ URUGUAI, V. Bases ... op.cit.p.18

${ }^{235}$ URUGUAI, V. Ensaio ... op.cit. p.203.

${ }^{236}$ URUGUAI, V. Ensaio ... op.cit. p. 204.

${ }^{237}$ URUGUAI, V. Ensaio ... op.cit. p.204.
} 
extremidades" ${ }^{238}$. Segundo o visconde, isso ocorria pois grande parte dos regulamentos das secretarias não estabelecia uma proporção adequada de agentes internos e agentes externos, havendo uma hipertrofia dos primeiros ${ }^{239}$. Além da necessidade de proporcionalidade entre agentes internos e externos, Uruguai defendia que os agentes administrativos nas localidades fossem de livre nomeação e demissão por parte do Poder Executivo.

Sendo os agentes administrativos agentes da administração, a qual faz parte do Poder Executivo, é fora de dúvida que é este quem os deve nomear, quando são destinados a levar a efeito atribuições relativas a negócios de interesses gerais.

Primeiramente porque esses agentes são instrumentos da administração e não deve ser ela privada de escolher os instrumentos por meio dos quais há de satisfazer a tarefa da qual é incumbida pelas leis.

Em segundo lugar porque é necessário que esses agentes estejam imbuídos do pensamento do governo e lhe sejam leais. Não é possível atingir bem esse fim não sendo tais agentes escolhidos e demitidos pela mesma administração cujos agentes são. Em terceiro lugar porque esses agentes obram debaixo da responsabilidade, pelo menos moral, do Poder Executivo e podem empenhá-la e comprometê-la. É portanto de rigorosa justiça que, salvas certas exceções, lhe pertença nomeá-los e demiti-los. Não devem portanto os agentes administrativos ser perpétuos e inamovíveis. ${ }^{240}$

Segundo Uruguai não havia nos municípios agentes administrativos nomeados fosse pelo governo central, fosse pelos Presidentes. Na ausência desses agentes que levassem a ação dos Presidentes "aos pontos remotos de extensíssimas Províncias", serviam-se eles das Câmaras Municipais, dos magistrados do Poder Judiciário e dos empregados da Polícia ${ }^{241}$. Isso gerava o grande inconveniente de essas autoridades assumirem funções administrativas que não lhes competiam.

Vemos com isto, que Uruguai possuía um plano bem concreto no que dizia respeito à organização do contencioso administrativo. Organizando-o em primeira e segunda instância, por meio de Conselhos de Presidência nomeados pelo governo e por comissários dos Presidentes nas localidades e, criando no Conselho de Estado uma Seção específica para isso (além de uma secretaria que seria encarregada de organizar a jurisprudência); seria possível ultrapassar as dificuldades então existentes para o cumprimento das leis, assegurando às partes as garantias processuais que teriam na

\footnotetext{
${ }^{238}$ URUGUAI, V. Ensaio... op.cit. p.217

${ }^{239}$ URUGUAI, V. Ensaio ... op.cit. p.205.

${ }^{240}$ URUGUAI, V. Ensaio ... op.cit. p. 205-206.

${ }^{241}$ URUGUAI, V. Ensaio ... op.cit. p.209.
} 
justiça comum. Essa organização seria para o governo central uma garantia maior do cumprimento de suas decisões, sem que fosse necessário negociar constantemente como se fazia - com as autoridades locais e provinciais ${ }^{242}$. Seria um modo de ter nas localidades um agente subordinado ao poder central e não às Assembléias Provinciais. Além disso, evitaria que outros poderes usurpassem essa função administrativa, cuja subordinação ao Poder Executivo central considerava de primordial importância, uma vez que somente este obrava segundo a razão de Estado.

O projeto de Uruguai para a organização do contencioso administrativo mostra claramente que se tratava de uma tentativa de reduzir o poder das Assembléias Provinciais com a introdução de agentes. O poder das Assembléias, que Uruguai considerava excessivo, fez com que ele defendesse uma emancipação das municipalidades da tutela das Assembléias Provinciais, como se discutirá no Capítulo 3. Todavia, é preciso deixar claro que ao fazer essa defesa das municipalidades, o que estava em questão não era efetivamente a sorte dos municípios, mas sim o poder das Assembléias. Ou seja, as municipalidades eram um meio discursivo para se contrapor aos legislativos provinciais. As propostas de organização das justiça administrativa tem como fio condutor, a extensão dos braços do governo central até as localidades, concorrendo assim com as Assembléias.

\section{3 - O Visconde do Uruguai E o Debate Sobre o Contencioso Administrativo.}

Se nas Bases Uruguai deixou claro o seu projeto de organização do contencioso administrativo, aprofundou sua reflexão no Ensaio, que, segundo ele, tivera origem no parecer encomendado por Olinda. Ambos os trabalhos de Uruguai dialogam diretamente com as obras de José Antonio Pimenta Bueno e Aureliano Cândido Tavares Bastos. Conforme veremos, no caso de Pimenta Bueno, esse diálogo extrapola

\footnotetext{
${ }^{242}$ Conforme visto no capítulo 1, a Lei de 3 de dezembro de 1841 dera ao governo central um grande número de cargos de livre nomeação que poderiam ser negociados em troca de apoio aos candidatos do governo. A mesa eleitoral continuava sendo controlada pelas autoridades eletivas locais. Contudo, a despeito do poder que as autoridades eletivas mantiveram, a presença de um agente administrativo do governo poderia, na visão dos políticos da época, embaraçar-lhes a ação, ou no mínimo retardá-la.
} 
o âmbito dos livros de direito, sendo inclusive por eles discutido na Seção de Justiça e Negócios Estrangeiros do Conselho de Estado.

Em 1857, no Direito Público Brasileiro e Análise da Constituição do Império, Pimenta Bueno faz diversas reflexões a respeito do Direito Administrativo. No primeiro capítulo, faz uma distinção entre o Direito em geral e os "dois grandes interesses que formam sua divisão". O Direito em geral seria o complexo de ditames que à luz da inteligência visam manter e garantir as "boas relações naturais ou cíveis, administrativas ou políticas do homem, da sociedade ou dos Estados”. Já os grandes interesses são, segundo Pimenta Bueno, o interesse geral, coletivo ou comum e o interesse particular, ou individual ${ }^{243}$. Contudo, pondera que esses dois tipos de interesse estavam sujeitos a entrarem em conflito, o que traria um prejuízo recíproco. Por esse motivo, "a razão e a ciência de todos os países civilizados" buscaram distinguir as relações entre os dois tipos de interesse, de modo que o interesse particular tivesse sempre de ceder ao interesse geral. Dessa distinção, teriam surgido dois tipos de Direito: o Direito Público e Administrativo, correspondente à ordem pública; e o Direito Particular, correspondente à ordem privada ${ }^{244}$.

Pimenta Bueno considerava que essa divisão acarretava a dupla existência do Poder Administrativo e do Poder Judicial, que, a seu ver, jamais deveriam ter suas atribuições confundidas. Quanto ao Poder Administrativo, afirma que a gerência das relações do cidadão com o Estado, nas quais entrava em questão o interesse comum, deveria pertencer ao Poder Executivo. Já o Poder Judicial seria o único que poderia zelar pelo Direito Particular, pois deixá-lo sob a tutela do Poder Executivo significaria escravizar as liberdades e os direitos civis, que poderiam ser embaraçados pela evocação do interesse geral $^{245}$.

Pimenta Bueno, ademais, distingue os diversos ramos do Direito Público e do Direito Particular. O Direito Público, em sua concepção, dividia-se em: Direito Público, interno, universal e positivo, no qual se sobressaíam as questões constitucionais; Direito Público externo, natural, e positivo, marítimo, diplomático e eclesiástico; e Direito Administrativo. Já o Direito Particular se ramificava em: Direito Civil; Direito

\footnotetext{
${ }^{243}$ PIMENTA BUENO, J. A. Direito Público ... op.cit. p. 62.

${ }^{244}$ PIMENTA BUENO, J. A. Direito Público ... op.cit. p. 63.

${ }^{245}$ PIMENTA BUENO, J. A. Direito Público ... op.cit. p. 63.
} 
Comercial; Direito Criminal; e Direito Internacional particular ou privado ${ }^{246}$. Sobre o Direito Administrativo, que nos interessa particularmente nesse capítulo, Pimenta Bueno afirmava:

[...] é a ciência da administração, a teoria racional de competência e da ação do Poder Executivo, e de seus agentes, em sua gestão, e relações com os direitos e obrigações dos administradores, em vistas do interesse eletivo, ou geral da sociedade. É a ciência que estuda e proclama as regras e condições gerais que são apropriadas para segurar o melhor desempenho do serviço administrativo, o bem-estar, a prosperidade social; é quem examina e esclarece os elementos da administração, as discussões dos negócios públicos, as opiniões e atos dos conselhos, e demais órgãos do Poder Executivo: é finalmente quem assinala os vícios, indica as lacunas, as reformas, os melhoramentos que o interesse social reclama. ${ }^{247}$

O autor partia, assim, da premissa de que o contencioso administrativo era de extrema importância para que não se submetessem os interesses gerais aos direitos individuais. A partir daí, procedia a uma distinção entre Poder Executivo e Poder Judicial. O primeiro teria por atribuição a execução das leis da ordem pública ou administrativa, o regulamento e proteção dos interesses coletivos, devendo sempre buscar o triunfo desses interesses na relação do cidadão com o Estado, ainda que em sacrifício de interesses individuais. O segundo teria sob sua responsabilidade a aplicação das leis que formam o Direito Particular. Seu norte seria a justiça, e não o exame de quem era o interesse ${ }^{248}$.

Segundo Pimenta Bueno, o Poder Executivo se dividia em poder político ou governamental e em poder administrativo. O Poder Executivo em sua opinião podia tanto exercer de modo pleno e soberano suas atribuições, sem ferir nenhum direito, como pode durante esse exercício violar direitos. Na segunda hipótese, seus atos são passíveis de contestação legal ${ }^{249}$. Pondera então que, caso os atos da administração prejudicassem interesses particulares, esses deveriam se subordinar ao interesse público, que deveria predominar. O referido autor faz questão de lembrar que simples interesses não configuram direitos e também que caso a administração esbarrasse em interesses, caberia apenas o recurso gracioso. Contudo, afirma que quando os atos do Poder Executivo, ao invés de se conterem em sua órbita, infringissem as leis do Estado

\footnotetext{
${ }^{246}$ PIMENTA BUENO, J. A. Direito Público ... op.cit. p. 63-70.

${ }^{247}$ PIMENTA BUENO, J. A. Direito Público ... op.cit. p.66.

${ }^{248}$ PIMENTA BUENO, J. A. Direito Público ... op.cit. p. 94.

${ }^{249}$ PIMENTA BUENO, J. A. Direito Público...op.cit. p. 308.
} 
e, por conseguinte, direitos individuais, sua autoridade tornava-se passível de contestação mediante recurso contencioso ${ }^{250}$.

Nesse sentido, pontificava que o contencioso judicial não incluía e que não possuía motivos para se encarregar de questões que não fossem as dos particulares entre si, "movidos pelo amor aos seus interesses individuais". Em sua visão, a administração somente poderia ser subordinada ao Poder Judiciário quando figurasse como particular, ou seja, quando agisse como pessoa jurídica, contratando com particulares e ferindo seus direitos, sem haver uma razão fundada em interesse coletivo $^{251}$.

Uruguai, assim como Pimenta Bueno, faz diversas classificações a respeito do Direito. Em sua visão, o Direito Natural dizia respeito a regras universais comuna a todos os homens, consagradas pela filosofia do Direito ${ }^{252}$. Segundo ele, o Direito Civil ou Privado se contrapunha ao Direito Natural e ao Direito Público, pois tinha por objeto "o interesse individual, e compreende as leis que regem os contratos, as doações, as sucessões", e de maneira mais ampla, as relações bilaterais entre os indivíduos. A regulação das relações entre as pessoas, consoante Uruguai, possuía diversas ramificações no Direito: criminal, civil, marítimo, comercial e militar, entre outras ${ }^{253}$. Já o Direito não-privado dividi-se em: Direito Público Interno, ou Direito Público Constitucional, cujo fim seria a regularização de um Estado e as relações entre governantes e governados; e Direito Público Internacional ou Externo.

Quanto ao Direito Administrativo, Uruguai considerava que não podia ser mantido dentro dos "limites de uma lacônica definição". Contudo, ponderava que a definição mais satisfatória, mas carente de maior desenvolvimento, era aquela do jurisconsulto francês Louis Firmin Laferriére (1798-1861). Leferriére considerava o Direito Administrativo como a ciência do Poder Executivo, das administrações gerais e locais e dos conselhos administrativos, em sua relação com os direitos e interesses dos

\footnotetext{
${ }^{250}$ PIMENTA BUENO, J. A. Direito Público...op.cit. p. 308.

${ }^{251}$ PIMENTA BUENO, J. A. Direito Público...op.cit. p. 379.

${ }^{252}$ URUGUAI, V. Ensaio ... op.cit. p.79.

${ }^{253}$ URUGUAI, V. Ensaio ... op.cit. p. 80-81.
} 
administrados e com o interesse geral ${ }^{254}$. Assim, o Direito Administrativo segundo Uruguai:

[...] ocupa-se do interesse geral, e aplica-o aos casos especiais; regula e assegura a boa execução dos serviços públicos, como, por exemplo, provendo à justa repartição e cobrança dos impostos; fiscalizando as despesas públicas; protegendo e fiscalizando certas corporações e estabelecimentos de beneficência e socorros públicos; tomando medidas de polícia administrativa e preventiva, que tendam a assegurar aos cidadãos os benefícios da ordem, segurança e salubridade pública; provê à segurança do país e decide as questões contenciosas que surgem das medidas administrativas etc., etc.

De matérias tão vastas, tão minuciosas, tão complicadas, tão práticas não pode uma simples definição dar idéia completa e perfeita. ${ }^{255}$

A partir dessa discussão, Uruguai procurava distinguir os espaços do Direito Privado e do Direito Administrativo. Esse último, segundo ele, regia "direitos e interesses sociais", sendo sua preocupação com os interesses da ordem pública. Já o primeiro, se encarregava de "direitos e interesses privados", concedendo títulos, convenções e provas autênticas, e as regras da justiça. Outra diferença importante para o visconde, é que o Direito Privado deveria se tornar uniforme, ou seja, estar atrelado a uma legislação já existente. Já o Direito Administrativo, era variável, pois "toma muito mais a cor das instituições políticas, ressente-se muito mais do estado da sociedade do que o direito civil" 256 .

No capítulo 10 do Ensaio, Uruguai se refere às diferenças entre Poder Administrativo e Poder Judicial. Quanto ao Executivo, afirma que ele se divide em Poder Executivo puro e em Poder Administrativo, sendo que o primeiro seria exercido pelo chefe do Poder Executivo e seus ministros, enquanto o poder administrativo teria por órgãos uma série de agentes responsáveis e amovíveis ${ }^{257}$. No que diz respeito ao contencioso administrativo, Uruguai concebe os poderes administrativo e judicial como subordinados ao Legislativo, contra o qual não há recurso. Ainda assim, pontificava que a Justiça e administração operavam segundo razões diferentes, com as decisões judiciais sendo declarativas e irrevogáveis, ao passo que as decisões administrativas seriam dispositivas e mutáveis. Para ele, a administração era graciosa quando feria o interesse particular, com fundamento no interesse geral, enquanto o

\footnotetext{
${ }^{254}$ URUGUAI, V. Ensaio ... op.cit. p. 83-84.

${ }^{255}$ URUGUAI, V. Ensaio ... op.cit. p.85.

${ }^{256}$ URUGUAI, V. Ensaio ... op.cit. p. 104-105.

${ }^{257}$ URUGUAI, V. Ensaio... op.cit. p. 126-127.
} 
conflito contencioso advinha de situações em que um indivíduo considerasse seu direito ferido em função da ação do Estado em nome do interesse público ${ }^{258}$. Assim, a ação da administração poderia ferir tanto direitos como interesses dos particulares. Apesar de o interesse geral ter proeminência perante o particular, Uruguai considerava que tanto os direitos quanto os interesses particulares não deveriam ficar abandonados sem garantias processuais. Segundo Uruguai, o Poder Executivo possuía também a característica de ser proprietário, ou seja, de ser uma Pessoa Jurídica. Por essa razão, considerava que quando o Estado agia como proprietário, os contratos que celebrava possuíam o caráter de convenções particulares, estando seu arbítrio ao encargo do Poder Judiciário ${ }^{259}$. Contudo, a ação do Estado como administrador podia em certos momentos colidir com interesses ou direitos de particulares. Neste caso:

Se é evidente que a administração não deve ficar peada quando na promoção do bem público e no cumprimento dos deveres que lhe impõem as leis, encontra obstáculos nos interesses e em certos direitos dos particulares, é também evidente que esses interesses e direitos não devem ficar abandonados à mercê de mero arbítrio. Devem a organização e as leis administrativas dar-lhes garantias de audiência, de discussão, de exame, de conselho, de publicidade e de recurso, para a consideração e reconsideração dos assuntos. Nesta parte a nossa legislação é extremamente deficiente e arbitrária, e não oferece garantias suficientes, como teremos ocasião de observar. ${ }^{260}$

Como mencionado anteriormente, para o visconde, a diferença entre interesses e direitos estaria na base da distinção dos dois grandes campos da atividade administrativa: a jurisdição graciosa e a jurisdição contenciosa. Segundo ele, interesse seria a vantagem que importa para alguém de que não seja adotada determinada medida pela administração. De acordo com o autor, o interesse teria como pré-requisito o fato de não estar consagrado em leis ou atos administrativos; pois caso isso ocorresse, deixaria de ser um interesse e se tornaria um direito. Segundo ele, direito seria aquilo que está inerente a alguém por virtude da lei. Uruguai cita como exemplo a decisão do governo de abrir uma estrada. Um município poderia ter interesse de que ela passasse em sua vila, pois isto contribuiria para seu desenvolvimento. Caso a administração não atendesse à demanda do município, ela estaria agindo dentro de seu direito, pois simplesmente contrariava um interesse, mas sem violar qualquer direito garantido pela

\footnotetext{
${ }^{258}$ URUGUAI, V. Ensaio ... op.cit. p. 133.

${ }^{259}$ URUGUAI, V. Ensaio... op.cit. p. 137-138.

${ }^{260}$ URUGUAI, V. Ensaio... op.cit. p.139.
} 
lei ao município. Assim, caso a administração fizesse uma concessão a um particular, o objeto concedido se tornaria propriedade do outorgado, e fosse este administrativo revogado ou violado, haveria a violação de um direito adquirido, sendo que a reclamação e a discussão se tornariam então contenciosas.

Para Uruguai, a razão de Estado era algo crucial para definir a esfera do contencioso administrativo, tanto assim que as legislações não seriam para ele gerais ao ponto de não sofrerem exceções "aconselhadas pela razão de Estado". Segundo o autor, haveria questões de natureza graciosas que poderiam ser tratadas de forma contenciosa, bem como questões contenciosas que podem ser tratadas como questões graciosas. Do mesmo modo, em sua visão, havia questões de natureza judicial que a lei sujeitava à autoridade administrativa e, questões administrativas sujeitas à autoridade judicial. Para ele, isso dependia de "lei expressa, fundada em uma razão de Estado." Quanto a isso, cita como exemplo os apresamentos e os julgamentos feitos pela Auditoria da Marinha no caso do tráfico de escravos. Em sua visão, a despeito de ser uma questão, a princípio judiciária, era tratada por autoridades administrativas devido à razão de Estado, ou seja, havia "considerações diplomáticas" das quais dependiam a segurança e a soberania do país ${ }^{261}$. Ou seja, tratava-se de uma razão de Estado.

Uruguai defendia que, em casos do contencioso administrativo a audiência do Conselho de Estado deveria ser obrigatória; assim em casos como o da Lei Eusébio de Queiroz, sua audiência era mandatória, pois ali eram julgadas em última instância as presas do tráfico africano, que a Auditoria da Marinha julgava em primeira instância. Uruguai considerava, portanto que, se o julgamento do Conselho de Estado fosse deliberativo e não consultivo, isso embaraçaria a ação do governo, e tiraria desse do Conselho de Estado a sua característica de tribunal administrativo, pois o vestiria com roupagens do Poder Judiciário. Conforme o autor:

E se os tribunais administrativos, quanto ao contencioso, salvo certos casos de menor importância, julgassem definitivamente, desapareceria a responsabilidade ministerial quanto a esses julgamentos. O ministro não poderia ser responsável por uma decisão na qual não interviera. Dar-se-iam atos que pela sua natureza estão compreendidos no círculo das atribuições do Executivo, e pelos quais não seriam, todavia, os ministros

\footnotetext{
${ }^{261}$ URUGUAI, V. Ensaio... op.cit. p.149. "Era preciso atacar vigorosamente o tráfico. A morosidade e o rigor das formas judiciárias tornavam os tribunais judiciários menos próprios para conseguir esse fim com o vigor e presteza que convinham." Idem Ibbidem.
} 
responsáveis, porque esses atos emanariam completos, perfeitos e exeqüíveis de funcionários que lhes são, todavia, inferiores na hierarquia administrativa. ${ }^{262}$

Logo, o Conselho de Estado era um tribunal administrativo, pois, o processo perante ele era marcado em regulamento tanto do que dizia respeito às diligências, como em relação à atuação dos advogados, à inquirição de testemunhas, à audiência das partes e demais produções de provas ${ }^{263}$. Isso era fundamental, pois "assegura um exame mais acurado e uma decisão mais justa e ilustrada"264.

Para além disso, contudo, Uruguai defendia que o Conselho de Estado deveria ter um outro presidente para assuntos administrativos, que não o monarca, pois este não poderia ter tempo para se ocupar de questões administrativas, "posto que muito altas e nobres, não são porém compatíveis com a alta dignidade imperial". O visconde também ponderava que os ministros são maus presidentes de seções, pois muitos eram novatos em questões administrativas, tendo sido levados ao gabinete somente por conveniências políticas. Porém, não só destacava também o fato de que os ministros eram constantemente mudados, bem como os conselheiros trocados de seção, não havendo, portanto na presidência das seções quem mantivesse um senso mínimo de continuidade. Finalmente, pontificava que ocorria de os ministros não poderem presidir com regularidade as seções quando as Câmaras se encontravam reunidas.

Vale lembrar que o visconde, na época de publicação do Ensaio, considerava novatos vários dos ministros então à frente do governo, e que "na presença das questões, com homens mais práticos, mais versados nelas", sua inexperiência se tornaria patente. Por essas razões, Uruguai afirmava que do modo como o Conselho de Estado encontrava-se organizado, não era possível criar uma tradição e uma jurisprudência administrativa. Essa proposta de Uruguai de fazer com que homens mais experientes e versados nas questões administrativas se tornassem presidentes das seções, em detrimento dos ministros e presidissem o Conselho de Estado Pleno em questões administrativas, vinha atender aos interesses de seu grupo. Muitos dos chamados homens novos, a exemplo de Nabuco de Araújo, despontaram na política

\footnotetext{
${ }^{262}$ URUGUAI, V. Ensaio... op.cit. p. 194.

${ }^{263}$ URUGUAI, V. Ensaio... op.cit. p. 193.

${ }^{264}$ URUGUAI, V. Ensaio... op.cit. p.195.
} 
ministerial a partir do ministério da Conciliação. Isso, sem dúvida marcara em período no qual os saquaremas perderam cada vez mais espaço político. Modificando a estrutura do Conselho de Estado, no tocante às questões administrativas, estaria retirando em parte o poder político desses novos gabinetes. Afinal, se essas novas funções seriam preenchidas por homens mais experientes e versados nessas questões, certamente isso tinha endereço certo: o próprio Uruguai e seu grupo político. Em suas novas funções, dariam o parecer final em diversos assuntos dos novos gabinetes.

Assim, tanto Uruguai quanto Pimenta Bueno defendiam que o contencioso administrativo deveria ser independente do Poder Judiciário. Para Uruguai, não se poderia deixar de conceder à administração a função de decidir sobre questões administrativas contenciosas, necessitando, contudo, rodear essas decisões de cautelas e garantias que evitassem o abuso ${ }^{265}$. Segundo ele, a inamovibilidade não teria lugar no contencioso administrativo, pois isso acabaria com a administração e criaria dois sistemas judiciais ${ }^{266}$. Além disso, era crucial ao governo poder nomear e demitir livremente seus agentes, pois isso dava ao governo central o controle do contencioso administrativo. Esse controle pelo poder central, aliado ao fato de propor a reorganização do Conselho de Estado nas questões administrativas, conferiria um maior espaço político ao seu grupo.

Aureliano Candido Tavares Bastos ${ }^{267}$, diferentemente dos outros dois, era político liberal. Entre o fim da década de 1850 e início da década de 1860 publicou

\footnotetext{
${ }^{265}$ URUGUAI, V. Ensaio... op.cit. p.162.

266 URUGUAI, V. Ensaio... op.cit. p.161. Para Ribas, a competência do poder judicial encontra-se restrita às questões cíveis e criminais. $\mathrm{O}$ autor considera que caso o administrador, sempre que no exercício de sua função, deparar-se com uma pretensão que se diz fundada em direito, devesse nesse caso suspender sua ação, sujeitando a solução à outra autoridade, seria tolhido do desempenho de suas atividades, provocando assim graves riscos à prosperidade e a própria conservação da sociedade. Em sua visão, é necessário armar a administração com o poder de "arredar os embaraços que lhe possam tentar opor os administrados, escudados por pretendidos direitos; e para este fim deve-lhe ser concedida a atribuição de julgar da justiça ou injustiça dessas preterições, salvo se os direitos alegados forem dos que estão sujeitos á competência do poder judicial”. RIBAS, A.J. op.cit. p. 161-163.

${ }^{267}$ Sobre Tavares Bastos ver: FERREIRA, G.N. Centralização e Descentralização no Império: o Debate Entre Tavares Bastos e Visconde de Uruguai. São Paulo, Editora 34 e Departamento de Ciência política da USP, 1999; ABREU, E.S.A. O Evangelho do Comércio Universal. O Desempenho de Tavares Bastos na Liga Progressista e no Partido Liberal (1861-1862). Tese de Doutoramento apresentada ao Departamento de História do Instituto de Filosofia e Ciências Humanas da Universidade Estadual de Campinas, 2004.
} 
diversas cartas assinadas sob o pseudônimo de "O Solitário" no Correio Mercantil ${ }^{268}$, republicadas todas em 1862 na forma de livro. Tavares Bastos tratava então de diversos temas, como liberdade da cabotagem, abertura do Amazonas ${ }^{269}$, e comunicações com os Estados Unidos. Poucos meses depois, foi publicado o Ensaio do Visconde do Uruguai, seguido, no ano seguinte, por uma reedição do livro de Tavares Bastos, com a inclusão de um novo tópico, com cartas que tratavam do tema da reforma administrativa. Mas a referência à obra do visconde não ficava restrita ao novo tópico, aparecia também em diversas notas às cartas anteriormente escritas.

Tavares Bastos atacava, entre outras coisas, a proposta de organização do contencioso administrativo feita por Uruguai nas Bases e também as idéias de Pimenta Bueno, publicadas em sua obra Direito Público e Análise da Constituição do Império. Segundo Lydia Garner, uma das principais críticas de Tavares Bastos à institucionalização da justiça administrativa se dava em função de considerar o Regulamento de 5 de fevereiro bastante vago, no que dizia respeito ao modo de se interporem recursos em processos administrativos, o que, para ele, implicava que o referido Regulamento não oferecia garantias aos direitos dos apelantes ${ }^{270}$.

Ao falar do livro de Pimenta Bueno, o político liberal se posicionava contrariamente à idéia expressa na obra de criar agentes executivos que coadjuvassem com os presidentes de Província nas localidades, criticando conjuntamente Uruguai por defender idéia semelhante nas Bases. Em sua opinião, Uruguai não se esquecia de sua origem francesa (referência tanto ao Direito Administrativo, quanto ao nascimento de Uruguai, em Paris.), sendo a criação de conselhos de presidência e agentes nos

\footnotetext{
${ }^{268}$ As cartas do Solitário não passaram desapercebidas nas anotações de Dom Pedro II em seu diário. Vale a pena a longa citação da anotação do dia 14 de março de 1862 , pois parece inclinar-se mais às posições de Uruguai que às do autor das cartas: "Tenho lido com atenção os artigos do Solitário publicados pelo Mercantil que parecem ser do Jequitinhonha, ainda que um amigo dele até diga que o Jequitinhonha professa idéias opostas às do Solitário. As idéias de liberdade que o solitário advoga agradam-me; porém não creio na conveniência dum sistema baseado sobre elas, e certas indústrias são indispensáveis a qualquer país, e quando pouco desenvolvidas não podem prescindir de proteção que não é senão um sacrifício que os nacionais fazem durante tempo mais ou menos longo para irem firmando sua verdadeira independência."[Grifos Meus]. Diário do Imperador Dom Pedro II in: Anuário do Museu Imperial op.cit. p.64.

${ }^{269}$ Apesar de não ser o tema dessa dissertação, a questão da navegação do Amazonas em muito contrapôs Tavares Bastos a Uruguai. Anos antes da publicação das Cartas do Solitário, Uruguai dera um parecer no Conselho de Estado Pleno em 1 de abril de 1854 a respeito da questão.

${ }^{270}$ GARNER, L. In Pursuit... op.cit. p.468.
} 
municípios um malefício que aumentaria ainda mais a centralização, que Tavares Bastos queria combater. Para ele, o projeto de Uruguai "arredondava o círculo do funcionalismo", colocando nas localidades, onde o governo já possuía delegados, subdelegados e juízes, mais agentes subordinados ao seu controle ${ }^{271}$.

Tavares Bastos critica o contencioso administrativo brasileiro, afirmando que a administração no Brasil era uma máquina pesada e que se produzia algo de útil, era somente após ter "atropelado e esmagado no seu andar sonolento, muitos interesses individuais e gerais". Assim, o contencioso administrativo respirava realidade somente no âmbito do Tesouro, onde possuía organização de primeira e segunda instância ${ }^{272}$, embora isso não o dissuadisse de suas críticas a esse sistema.

Afirmando que o livro de Pimenta Bueno dera impulso à discussão de como constituir as administrações provinciais de modo proveitoso, lamentava:

Desgraçadamente o escritor revelou-se partidário do espírito das instituições francesas, que sempre condenaremos e que ele desejava ver imitadas. Entusiasta do contencioso administrativo e não satisfeito em vê-lo, decretado pelo governo, figurar nas atribuições do Conselho de Estado, ele quereria que todas as questões daquela natureza começassem nas províncias por ser processadas e julgadas perante um conselho de presidência nomeado pelo governo imperial. ${ }^{273}$

Contestando as idéias de Uruguai, criticava a insistência na criação de Conselhos de Presidência e de agentes administrativos nas localidades. Em sua visão, o livro do visconde procurava fornecer os fundamentos de uma reforma da qual seu autor estaria pretendendo fazer depender o futuro das Províncias. Tavares Bastos dizia ainda que nada convenceria o leitor que o mal da concentração de atribuições administrativas no Presidente da Província viesse a ser extinto com a criação de um novo corpo de funcionários proposto nas Bases ${ }^{274}$.

Ao finalizar a carta V, Tavares Bastos afirmava que a extinção do contencioso administrativo estaria na base do que ele considerava ser uma reforma séria e profunda. Ou seja, o pouco que havia de contencioso administrativo organizado no Império deveria deixar de existir, segundo Tavares Bastos. Além disso, defendia a concessão

${ }^{271}$ TAVARES BASTOS, A.C. Cartas do Solitário. Rio de Janeiro, 1863, p. 47.

${ }^{272}$ TAVARES BASTOS, A.C. Cartas do Solitário. Rio de Janeiro, 1863, p. 5-6

${ }^{273}$ TAVARES BASTOS, op.cit. p.46

${ }^{274}$ TAVARES BASTOS, op.cit. p.47 
aos presidentes do direito de nomear e demitir um grande número de empregados gerais nas províncias, processar e julgar definitivamente na maioria dos $\operatorname{casos}^{275}$. Isso, sem dúvida é uma divergência de fundo a respeito de como deveria funcionar o governo, pois, no modelo proposto por Tavares Bastos, o governo central ficava com um espaço muito menor de ingerência nas Províncias e nas localidades.

Uruguai possuía, portanto, um plano concreto de reorganização do contencioso administrativo, plano que não só aparecia em suas obras, mas também no debate político de seu tempo, nas instituições em que tinha assento. Conforme aponta Cecília Helena de Salles Oliveira ${ }^{276}$, as idéias defendidas pelo visconde vinham de uma longa experiência acumulada na gestão dos negócios do Estado. Nesse sentido, os pareceres da Seção de Justiça do Conselho de Estado mostram como um tema caro à suas obras, como o do contencioso administrativo, estava colocado diante dele no cotidiano de suas atividades como Conselheiro de Estado;tema caro ao visconde, mas também a seus colegas conselheiros.

Na Seção de Justiça, houve uma polarização entre Uruguai e Pimenta Bueno de um lado e Jequitinhonha de outro. Em 1 de junho de 1866, a Seção foi chamada a se manifestar sobre um conflito de jurisdição levantado pela Presidência do Rio de Janeiro em relação ao Juízo dos Feitos da Fazenda da mesma Província.

O caso consistia no seguinte: o governo provincial do Rio de Janeiro celebrara um contrato com Antônio Soares de Alvarenga e Mello para a conservação de uma estrada. Todavia, entendeu que ele violara as estipulações contratadas e rescindiu-o, além de se negar ao pagamento das prestações que ele reclamava. Antonio Soares, após ter seu pedido indeferido, intentou uma ação contra o Tesouro Provincial pelo Juízo dos Feitos da Fazenda ${ }^{277}$. Todavia, o Procurador Fiscal declarava que o juízo era incompetente para tomar conhecimento da causa, razão pela qual o Juiz que então servia declarou-se incompetente por despacho de 30 de Setembro de 1864. Antonio Soares recorreu desta decisão por meio de agravo, e a Relação do Rio de Janeiro, por Acórdão de 18 de Outubro de 1865, deu provimento ao agravo, declarando que o Juízo era competente, devendo prosseguir no processo. O novo Juiz acatou o provimento,

${ }^{275}$ TAVARES BASTOS, op.cit. p.55

${ }^{276}$ OLIVEIRA, C.H.S. O Conselho de Estado... op.cit. p.52.

${ }^{277}$ CAROATÁ, J.P.J.S. op.cit. p. 1312 
prosseguindo com a ação. Porém, a presidência da província ordenou ao juiz que fundamentasse as razões pelas quais se julgava competente, uma vez que a presidência entendia que se tratava de uma questão administrativa ${ }^{278}$.

O Juiz respondeu, em Oficio de 7 de Dezembro de 1864 que o Decreto n. 2343 de 29 de Janeiro de 1859 referia-se somente ao Ministério da Fazenda, não sendo aplicado a outros ministérios, "os quais se devem dirigir pelos seus respectivos Regulamentos"279.

A Presidência não se conformou com as razões expostas pelo Juiz e, por meio do Aviso de 9 de Fevereiro de 1865, afirmou que não se tratava de contenda sobre a propriedade de Alvarenga, direito que lhe era garantido pela Constituição. Se fosse o caso, dizia o Aviso, seria matéria para ser tratada pelo Poder Judiciário. Na visão da presidência, tratava-se de um contrato, que, sendo procedente de um ato determinado pela administração provincial, fazia com que fosse uma questão de contencioso administrativo $^{280}$. O Aviso ainda citava o Ensaio do Visconde do Uruguai, afirmando que nessa obra, ficara muito claro o que eram as questões de competência dos tribunais ordinários, e aquelas de competência dos "tribunais ou autoridades administrativas". Assim, o juiz suspendeu seu procedimento. Contudo, em 4 de Abril de 1865 fundamentou de novo sua competência, afirmando não estar convencido de que se tratava de um caso de contencioso administrativo ${ }^{281}$.

Pimenta Bueno, Relator do Parecer da Seção de Justiça, que é assinado também por Uruguai afirma que não assistia à presidência do Rio de Janeiro qualquer razão para denegar a competência do Juízo dos feitos da Fazenda da mesma província ${ }^{282}$, fundamentando seu parecer nas seguintes razões:

É indispensável fixar, e compreender bem, o que é o contencioso judiciário, ou justiça comum, o que é o contencioso administrativo, ou justiça excepcional da administração, para não divagar em regiões puramente imaginárias, e desconhecidas com grave detrimento dos direitos privados e bem do Estado. A regra geral e protetora da ordem social, é que toda a questão contenciosa, todo litígio de direitos mormente individuais ou civis, que por isso mesmo demanda julgamento, pertence á alçada do Poder Judiciário, e Juízo comum. Para isso é que foi constituído esse Poder, e este foro [...] É

\footnotetext{
${ }^{278}$ CAROATÁ, J.P.J.S. op.cit. p. 1312

${ }^{279}$ CAROATÁ, J.P.J.S. op.cit. p. 1313

${ }^{280}$ CAROATÁ, J.P.J.S. op.cit. p. 1313-1314

${ }^{281}$ CAROATÁ, J.P.J.S. op.cit. p. 1314-1316

${ }^{282}$ CAROATÁ, J.P.J.S. op.cit. p. 1318
} 
pois preciso para isso que haja Lei expressa, e não simples conjecturas, razões de conveniência, analogia, ou outros argumentos improcedentes que não tiram atribuições ao Poder Judiciário; que não desaforam o cidadão de seus Juízes naturais e nem dão ao Poder Administrativo, o que ele não tem. ${ }^{283}$

Segundo Pimenta Bueno, tirando o Regulamento do Conselho de Estado de 5 de Fevereiro de 1842, e as disposições do Decreto de 29 de Janeiro de 1859 (que regulou o contencioso administrativo no âmbito da Fazenda) - que, em sua visão, não possuía aplicação alguma para o caso de Antonio Alvarenga - havia uma lacuna, e um grande silêncio na legislação muito prejudiciais, cuja consequiência era a de que o caso seria de competência dos tribunais judiciários ${ }^{284}$. Em sua visão, havia duas razões para afirmar a competência judiciária: primeiro, por não haver lei estabelecendo que casos como o que era discutido, fosse de competência administrativa; segundo, porque considerava que tratava-se de uma causa cível. Todavia, afirmava que convinha "por ventura subordinar certos contratos celebrados com a administração ao julgamento dela, mas a Le i ainda não fez isso."285

Jequitinhonha apresentou voto separado afirmando que o contencioso administrativo pressupunha como condições o ato da autoridade administrativa e o interesse privado, fundado em direito. Em sua opinião, estas duas condições eram completamente estranhas ao foro da justiça comum. Quanto ao caso de Antonio Alvarenga, afirmava:

Ora a simples leitura dos papeis relativos ao conflito levantado pelo Presidente da Província do Rio de Janeiro convence que a questão é da competência do contencioso administrativo o que foi exuberantemente provado por ele em o seu oficio ao Juiz dos Feitos da Fazenda. E nesse mesmo oficio provou também o mesmo Presidente que havia legislação que o determinava, sendo esta a 1.» vez que o Conselheiro Visconde de Jequitinhonha vê pôr em duvida a constitucionalidade das disposições do Decreto $\mathrm{n}^{\circ}$ 2343, em que trata dos contratos civis da Fazenda. ${ }^{286}$

José Reinaldo de Lima Lopes destaca que havia no Conselho de Estado uma tendência de respeitar os casos que estivessem à espera de decisão judicial, além de se procurar evitar a invasão desnecessária do Poder Judiciário. Contudo, afirma Lopes

${ }^{283}$ CAROATÁ, J.P.J.S. op.cit. p. 1318-1319

${ }^{284}$ CAROATÁ, J.P.J.S. op.cit. p. 1319

${ }^{285}$ CAROATÁ, J.P.J.S. op.cit. p. 1319

${ }^{286}$ CAROATÁ, J.P.J.S. op.cit. p. 1329 
que, a partir de 1866, Nabuco de Araújo passou a integrar a Seção de Justiça, desenvolvendo ampla campanha contra o contencioso administrativo ${ }^{287}$. Vale destacar que Nabuco ascendera ao Conselho justamente em substituição de Uruguai que morrera no mesmo ano, ou seja, tratava-se de um momento de mudança geracional no conselho. Como Lopes afirma, a partir de 1873, Nabuco recrudesceu sua campanha. Nabuco era justamente um dos políticos novos que Uruguai criticava. Sua campanha, e mesmo sua entrada no Conselho puderam deslanchar somente depois que o líder saquarema havia morrido.

Vemos então, que Uruguai, que no início dos anos de 1840 teve uma atuação fundamental na reintrodução do Conselho de Estado e na formulação de seu Regulamento, pretendia ir além disto, conforme fica muito claro nas Bases. Estas idéias, conforme vimos, não foram algo pensado depois de uma retirada da política, mas sim frutos de uma atuação constante nos órgãos do Estado, notadamente na Seção de Justiça do Conselho de Estado. Pode-se ver, inclusive, que um de seus interlocutores no debate político que se estendeu durante a década de 1860 era Pimenta Bueno, conselheiro de Estado como ele. Quanto à questão do contencioso administrativo, o que parece estar no centro da discussão para Uruguai é a razão de Estado. Apesar de na contenda de Antonio Alvarenga com a Província do Rio de Janeiro em 1866 ter assinado o parecer junto com Pimenta Bueno, sem apresentar voto em separado (como fez Jequitinhonha), havia deixado claro em seu Ensaio Sobre o Direito Administrativo o que pensava a respeito das chamadas desclassificações, ou seja, o direito de a administração, em nome do interesse geral, representado pela razão de Estado tratar questões judiciais como administrativas e vice-versa.

Mesmo no que diz respeito às questões eleitorais tratadas no Capítulo 1, a reforma administrativa pretendida por Uruguai possuía uma implicação prática. Com a criação de comissários do Presidente da Província nas localidades, e possuindo eles alguma parcela de poder para julgar casos do contencioso administrativo, ainda que o recurso ao Conselho de Presidência fosse obrigatório, poderia ser para o governo central, uma arma para aumentar seu cacife na busca de apoio a seus candidatos. Por meio das mencionadas desclassificações, poderia alegar razão de Estado ou

${ }^{287}$ LOPES, J.R.L. O Oráculo... op.cit. p.226. 
contrariedade do interesse coletivo para transformar em administrativa alguma decisão do Juiz de Paz, que presidia a Mesa Eleitoral. Mesmo que com os recursos obrigatórios esse tipo de medida pudesse ser anulada sem grandes dificuldades, uma vez que seria claro o abuso e o oportunismo, ela causaria no mínimo embaraços. Ou seja, a questão não era a de efetivamente anular as Mesas Eleitorais por meio dos comissários, mas de transformá-lo em um elemento de pressão para garantir a eleição de uma Câmara dócil ao gabinete. Quanto aos Conselhos de Presidência, eles seriam de nomeação pelo governo geral. Com isso, além do Presidente, o governo teria muito mais que simples agentes, mas um órgão seu, que deveria ser o depositário dos debates e das questões locais. Sua criação institucionalizaria a extensão dos braços do governo. Com isso, seria mais um órgão para contrabalançar o poder das Assembléias Provinciais, tema do próximo capítulo.

A discussão em torno do contencioso administrativo no Império, apesar de em diversos momentos parecer um debate mais do interesse de juristas do que de historiadores, é algo fundamental para se compreender os vários caminhos, e aposições políticas, no bojo do processo de consolidação do Estado Nacional que se desenrolava no Segundo Reinado. 


\section{Capítulo 3: Pelo Império, Contra a Província.}

A divisão de competências entre centro, províncias e municípios aparece como tema central no último livro do Visconde do Uruguai, os Estudos Práticos Sobre a Administração das Províncias no Brasil, de 1865. Contudo, a questão também já fora por ele abordada em seus trabalhos anteriores, as Bases Para Melhor Organização das Administrações Provinciais, de 1858, e no Ensaio Sobre o Direito Administrativo, de 1862. Nestas obras, além de abordar a questão do contencioso administrativo, critica o excesso de poder das Assembléias Provinciais, e defende a concessão de uma maior autonomia para as municipalidades.

Existe uma correlação entre esses trabalhos. Ao escrever o Ensaio, Uruguai afirmava que a "honrosa incumbência" que Olinda lhe dera, de escrever as Bases, despertara-lhe o desejo de organização e publicação de um trabalho mais completo, e de se entregar a um estudo consciencioso e aprofundado do direito administrativo, pois afirmava que dele "somente possuía as noções que não pode deixar de ter quem estudou a jurisprudência e [a] tem exercido por algum tempo" ${ }^{288}$. No início do Ensaio, também afirmou que essa obra seria o preâmbulo de um estudo mais detido sobre as administrações provinciais. Nos Estudos Práticos, Uruguai afirma que, quando publicou o Ensaio, em 1862 objetivava que o trabalho que se seguiria tivesse a dupla vantagem de conter a exposição positiva e metódica de toda a legislação administrativa brasileira, com vistas a servir de guia aos que dela se ocupavam, e também de compreender indicações que mostrassem as lacunas da legislação e os melhoramentos e reformas que julgava convenientes ${ }^{289}$. Ainda que, em sua obra de 1865 tenha deixado explícito que era sua intenção de dar prosseguimento à discussão, a morte lhe impediu de cumprir a tarefa.

O fato de a divisão de competências figurar nas obras fez com que se tornassem paradigmas para a historiografia que veio a se ocupar do tema. Ainda que, sem dúvida, tenha exposto suas opiniões e propostas de forma mais organizada e aprofundada nos

\footnotetext{
${ }^{288}$ URUGUAI, V. Ensaio Sobre o Direito Administrativo. in: CARVALHO, J.M. (ORG), Visconde do Uruguai. São Paulo: Editora 34, 2002. p.68.

${ }^{289}$ URUGUAI, V. Estudos Práticos Sobre a Administração de Províncias do Brasil, Rio de Janeiro: Typografia Nacional, 1865, p. III.
} 
trabalhos publicados, sua preocupação com o tema já vinha de sua experiência como Senador e no Conselheiro de Estado. Aqui, os principais assuntos relacionados à divisão de competências foram o direito de as Assembléias Provinciais legislarem sobre a força policial das províncias, sobre a anexação e desanexação dos ofícios de justiça, e a verificação de poderes dos membros das deputações provinciais.

A discussão que Uruguai fez em suas obras e nos espaços institucionais que continuou ocupando depois de sua saída dos gabinetes é importante, pois revela que o saquarema que esteve no centro da aprovação da Lei de 3 de dezembro de 1841 e que passou os regulamentos da mesma Lei, não era contrário ao concurso de outras esferas de governo. Defendeu em suas obras que fosse concedida uma maior autonomia municipal, dado o grande poder que as Assembléias Provinciais detinham sobre os municípios. Todavia, conforme se verá, isto não o impedia de reconhecer às Assembléias diversas atribuições.

\section{1 - A DEFINIÇÃo do ESPAÇO DAS ASSEMBLÉIAS}

Com a saída de Paulino do Ministério, sua participação nos debates do Legislativo diminuiu. Contudo, em 1854, participou de uma discussão a respeito do Parecer da Comissão das Assembléias Provinciais, que pedia que fosse sancionado o Decreto $\mathrm{n}^{\circ} 281$ de 9 de novembro de 1853, que fixava a força policial da Província do Rio Grande do Sul. A importância de se tratar desta discussão é que ela antecipa vários assuntos que foram amplamente tratados pelo Visconde do Uruguai em seus livros, e, também em seus pareceres no Conselho de Estado. O decreto se baseava no $\$ 2^{\circ}$ do Art.11 do Ato Adicional, que estabelecia como competência das Assembléias. Provinciais a fixação de sua força policial, a partir das informações fornecidas pelo Presidente da Província. O Presidente negou a sanção com base no $§ 2^{\circ}$ do Art.36 da Constituição, que dizia ser privativa da Câmara dos Deputados a iniciativa sobre recrutamento, pois, segundo o Decreto, caso o Presidente não completasse os quadros da força mediante engajamento voluntário, poderia, na forma da Lei, proceder ao recrutamento. $\mathrm{O}$ debate ocorreu na sessão de $1^{\circ}$ de junho de 1854 , e se iniciou com as considerações do Senador D. Manuel sobre a referida lei, afirmando: 
O SR. D. MANUEL: Mas como a Assembléia da Província de São Pedro se serviu dos termos - na forma das leis existentes, - concluiu que, uma vez que essas leis não se alteravam, e não se fazia lei sobre recrutamento, não tinha fundamento a negativa da sanção. $\mathrm{O}$ ato adicional marcou nos arts. 10 e 11 do modo mais claro os objetos sobre que as assembléias provinciais podem legislar, tudo o que não se achar na raia desses dois artigos está fora das suas atribuições. Mas o recrutamento não se acha compreendido nesses artigos, logo está fora da alçada das assembléias provinciais. Não tendo por outro lado sido revogado o art. $36, \S 2$, da constituição, segue-se que foi ele violado pela assembléia provincial. ${ }^{290}$

No decorrer da discussão, os Senadores Fernandes Chaves e Vergueiro se posicionaram favoravelmente ao parecer, ao passo que Rodrigues Torres e Dantas Leite se posicionaram contra. Nesta discussão, Paulino Soares de Souza defendeu o direito da Assembléia Provincial legislar sobre esta matéria. Ao invés de concordar com Rodrigues Torres, concordou com Vergueiro e Fernandes Chaves. No seu entendimento, a atribuição de fixar a força policial compreendia também a de completá-la mediante recrutamento, organizando os corpos policiais, estipulaando as penas e a maneira de julgar, pois o $\$ 2^{\circ}$ do art.36 da Constituição dizia respeito ao recrutamento para o exército e para a armada, não sendo possível buscar na Constituição limitação ao direito que o Ato Adicional dera às Assembléias. Diz o Senador:

O SR. SOARES DE SOUZA: Argumentou-se com os abusos que podem resultar se as assembléias provinciais tiverem o direito de legislar sobre recrutamento; mas elas nada mais fazem do que dar a autorização; quem faz proceder ao recrutamento é o presidente da província, isto é, - um delegado do governo imperial, - que não abusará, e que se o fizer será demitido. Não enxerga portanto esse perigo. (...) Conclui declarando que estas opiniões não são de hoje; são conscienciosas, e há muito que as professa. Vota pois, pelo projeto da nobre comissão. ${ }^{291}$

A idéia aqui expressa a respeito do papel do Presidente de Província como delegado do governo imperial traz consigo a noção de uma organicidade do Estado, que permeia todo o último livro do Visconde do Uruguai. Neste livro, assim como nos outros, Uruguai defendeu a criação de conselhos administrativos nas Províncias, subordinados a seu Presidente. Estes conselhos teriam, entre outras funções, a de serem tribunais do contencioso administrativo, que deveria ser organizado em primeira e segunda instância, conforme discutido no Capítulo 2.

\footnotetext{
${ }^{290}$ Anais do Senado, Sessão de $1^{\circ}$ de junho de 1854 . Volume 2, p.p. 3-4.

291 Anais do Senado, Sessão de $1^{\circ}$ de junho de 1854 . Volume 2, p.p. 13-14.
} 
A questão das atribuições das Assembléias Provinciais foi tratada por Uruguai no Conselho de Estado em 1857. No início daquele ano, o Conselho de Estado Pleno foi chamado a discutir um parecer das Seções da Guerra e da Justiça sobre o poder das Assembléias Provinciais de impor penas aos soldados permanentes e criar jurisdição de primeira e segunda instância para julgá-los. O interessante da ata desta Sessão do Conselho de Estado, é que há uma grande discussão entre Eusébio de Queiroz e o Visconde do Uruguai, dois dos integrantes da chamada trindade saquarema, com o último sustentando o direito das Assembléias e o primeiro se posicionando contrariamente. A Seção de Justiça, em seu parecer, aprovara que não competia às Assembléias criar este tipo de jurisdição. Subindo ao Conselho Pleno, o Visconde do Uruguai, que à época de aprovação do parecer (14 de janeiro de 1856) não se encontrava no Brasil, discursou longamente contra sua aprovação. Em sua visão as Assembléias possuíam o direito de criar jurisdições para processar soldados permanentes.

Ademais, em sua fala na sessão, Uruguai afirmou que a Lei de Interpretação do Ato Adicional guiou-se pelos mesmos princípios federais da Constituição norteamericana. Para ele, as leis deveriam deixar clara qual a competência de cada esfera de governo, de modo a evitar usurpações e confusões de interpretação. Em suas palavras:

A Lei da interpretação do Ato Adicional reuniu e concentrou a roda de se as forças da nação que aquela ação exagerada provocara. Foi uma reação justa, legal, e lógica, porque se fundou em princípios e em boa doutrina, que agora invocarei contra o que me parece exceder os limites daquela reação justa e lógica. Fundou-se aquela interpretação, aplicando-a em proveito da Monarquia, na mesma doutrina em que se baseavam os fundadores da Constituição Federal Americana, isto é, fundou-se no princípio acima exposto, o qual foi assim consignado no parecer da Comissão que apresentou o projeto de interpretação adotado sem alteração alguma. (...) A letra do Ato Adicional favorecia singularmente as invasões, que as Assembléias Provinciais tinham cometido, abrindo-lhes mui ancha porta. ${ }^{292}$

A seguir, Uruguai defendeu que os corpos policiais não fossem forças militarizadas, devendo assemelhar-se ao que eles eram na Inglaterra e na França. Fez também uma importante ressalva sobre os limites das Assembléias Provinciais, afirmando que as idéias que defendia, eram as mesmas que o guiaram quando fora

\footnotetext{
${ }^{292}$ RODRIGUES, J. H. (ORG.) Atas do Conselho de Estado Pleno, Terceiro Conselho de Estado (18501857). Brasília: Senado Federal, 1978, p.250. Grifos Meus.
} 
Presidente de Província. Dizia ele repugnar-se diante da idéia de admitir que as Assembléias impusessem penas e criassem jurisdições para aplicá-las, mas ponderava que eram "penas meramente de disciplina, que não isentam os réus daquelas em que incorrem pelas Leis Gerais, e que tem de ser impostas pela autoridade civil."293

Após longa exposição, o Visconde do Uruguai terminou de apresentar os motivos de seu voto, ressalvando que as Assembléias não possuíam o direito de invadir a jurisdição do Supremo Tribunal Militar. Seguindo a discussão, Eusébio de Queiroz contestou os argumentos de Uruguai, afirmando que o direito de legislar sobre força policial e de organizá-la, de impor disciplina e julgá-la era contraproducente, pois o Ato Adicional dizia fixar e não legislar. ${ }^{294}$ Ademais, Eusébio afirmava:

Nota mais a espécie de contradição em que se acha o Visconde quando censura a organização militar dada a esses Corpos, reconhecendo que o levantar tropas é direito majestático; pois desde que se reconheça nas Assembléias Provinciais o direito de legislar sobre a organização e disciplina desses Corpos, elas estão no seu direito legislando de modo próprio a vitalizá-los. E certamente quem pode fixar o número de graças de um Corpo, estabelecer sua organização, disciplina e penalidades, pode levantar um exército somente com o disfarce do nome. Ora tal não quiseram, nem podiam querer aqueles que decretaram o Ato Adicional. ${ }^{295}$

Ou seja, na visão de Eusébio, Uruguai estava defendendo que as Assembléias tivessem um poder que deveria pertencer somente ao governo geral. Em sua tréplica, o Visconde frisou, sobretudo, a importância da esfera municipal, afirmando ser a polícia uma instituição municipal. Esta afirmação é de grande relevância para a reflexão a respeito da defesa das municipalidades que faz em suas obras. Apesar de o tema dos corpos policiais não figurar ali, sua inserção neste debate em 1857 é importante para elucidar sua posição sobre o papel das Assembléias Provinciais.

Grande parte dos conflitos que a Seção de Justiça era chamada a arbitrar era referente a ofícios de justiça ${ }^{296}$. Estes conflitos, conforme o próprio Visconde do

\footnotetext{
${ }^{293}$ RODRIGUES, J. H. (ORG.) Atas do Conselho de Estado Pleno, Terceiro Conselho de Estado (18501857). Brasília: Senado Federal, 1978, p. 252. Grifos Meus.

${ }^{294}$ RODRIGUES, J. H. (ORG.) Atas do Conselho de Estado Pleno, Terceiro Conselho de Estado (18501857). Brasília: Senado Federal, 1978, p. 254.

${ }^{295}$ RODRIGUES, J. H. (ORG.) Atas do Conselho de Estado Pleno, Terceiro Conselho de Estado (18501857). Brasília> Senado Federal, 1978, p. 254.

${ }^{296}$ A Lei de 11 de outubro de 1827, que determinava a forma como seriam providos os ofícios de Justiça e Fazenda. Segundo o Art. $1^{\circ}$ desta lei, nenhum ofício de Justiça, ou Fazenda, seria conferido a título de propriedade. Pelo Art. $2^{\circ}$ ficava determinado que todos os ofícios de Justiça, ou Fazenda seriam conferidos, por títulos de serventias vitalícias, às pessoas, tivessem a idoneidade necessária para o seu
} 
Uruguai expressava, eram oriundos do fato de haver dívida eleitoral e gente para acomodar nos diversos cargos com os quais a Lei de 3 de dezembro havia dotado o governo central. Contudo, as Assembléias Provinciais mantiveram a atribuição de legislar sobre a anexação e desanexação dos ofícios, podendo inclusive criar e suprimir comarcas. Conseqüentemente, havia na esfera local conflitos entre apoiadores de um ou outro Partido. Uruguai reclamava também do fato de a mesma questão aparecer mais de uma vez no Conselho, como se nunca tivesse aparecido, como conseqüência da falta de uma organização da jurisprudência, como pôde ser visto no Capítulo 2. Com a consolidação do Estado, conflitos entre autoridades locais não só se transferiram para a esfera do judiciário ${ }^{297}$, mas também para a da administração, havendo uma conseqüente disputa por cargos e benefícios.

Em 1854, uma das muitas consultas que versavam sobre a questão dos ofícios de justiça ${ }^{298}$ foi a Consulta de 11 de outubro, "Sobre o ofício do Presidente da

exercício, e que serviriam neles pessoalmente, salvo o acesso regular, que lhes competisse por escala nas repartições, em que os houvesse. Portanto, tratava-se de uma concessão vitalícia, não de uma doação que conferisse direito de propriedade. Dizia ainda o Art. $3^{\circ}$ que o serventuário vitalício, que no exercício do ofício se impossibilitasse de continuar a exercê-lo por doença, que uma vez provasse perante o governo a sua impossibilidade, seu bom serviço e a ausência de outro meio de subsistência, poderia obter a terça parte do rendimento do ofício, segundo a sua lotação, à cargo dos sucessores no dito ofício. Os sucessores, contudo, poderiam contestar a veracidade dos motivos alegados, que, provados falsos, os livraria do encargo. A Lei também determinava em seu Art. $4^{\circ}$ que as pessoas que se encontrassem na posse da propriedade ou serventia vitalícia de alguns ofícios, e que pessoalmente não pudessem servir, seriam obrigadas a fazer nomeação de pessoa idônea para a serventia, no prazo de seis meses. Caso a nomeação não fosse feita dentro do prazo, dizia o Art.5 $5^{\circ}$ que perderiam o direito a ela, que seria feita pelos magistrados, ou autoridades, perante quem fossem servir os oficiais. Rezava o Art. $6^{\circ}$ que em os serventuários seriam providos por uma única vez para servirem o quanto vivessem os proprietários, ou serventuários vitalícios, ou durasse o seu legítimo impedimento, e eles não cometessem crime, ou erro, que os inabilitasse. Segundo o Art. $7^{\circ}$, os nomeados para as serventias não poderiam ser obrigados a pagar por elas mais do que um terço da quantia, em que fossem, ou estivessem lotados os rendimentos anuais de seus ofícios sob pena, aos que tivessem a mercê da propriedade, ou serventia vitalícia, de perderem os ofícios, e aos serventuários, de perderem a serventia, e pagarem como multa uma quantia igual à lotação de um ano, a qual seria aplicada em obras públicas da localidade. No caso de impedimento dos serventuários nomeados seriam os ofícios exercidos interinamente por pessoas que a lei designasse, ou que fossem escolhidas pela autoridade competente $\left(\right.$ Art. $\left.8^{\circ}\right)$. Lei de 11 de outubro de 1827 . Determina a forma por que devem ser providos os Ofícios de Justiça e Fazenda. Segundo José Reinaldo de Lima Lopes, a Lei não teve eficácia sobre a mente dos que detinham os ofícios, nem sobre os juristas do Império de modo geral. A Seção tinha como parte considerável de sua atividade, o arbitramento de conflitos envolvendo tabeliães, escrivães, etc. LOPES, J.R.L. O Oráculo... op.cit. o.257.

297 Ver: DANTAS, M.D. Para além "centros" e "periferias": autoridades locais, poder judiciário e arranjos políticos no Império do Brasil (o caso de uma comarca da província da Bahia). In: Seminário: De um Império a Outro, $3^{\text {a }}$ Parte, Mesa 2. Disponível em: www.estadonacional.usp.br.

${ }^{298}$ As questões referentes aos ofícios de justiça eram chave para o governo imperial, pois cabia às Assembléias Provinciais Legislar sobre eles. Eram no Conselho de Estado resolvidos diversos conflitos locais, ocupando ele, nas palavras de José Reinaldo de Lima Lopes, um papel de domesticação dos 
Província da Paraíba acerca da Lei da respectiva Assembléia Legislativa, que dividiu a Província em seis Comarcas"299.

O Presidente da Paraíba negara-se a sancionar a referida lei considerando não haver a necessidade de tantas novas comarcas, uma vez que a Assembléia aprovara a criação de três novas comarcas (dobrando, assim, o número de comarcas existentes). Voltando à Assembléia Provincial, foi aprovada novamente, sendo sancionada pelo Vice-Presidente, então em exercício. Porém, com base no Art. 15 do Ato Adicional, solicitou ao governo imperial que procedesse a uma classificação das comarcas. A Seção concordou com o Vice-Presidente a respeito da inconveniência da lei, mas o único meio legal de anulá-la seria por meio da própria Assembléia Provincial.

A Seção posto que ache fundadas as razões produzidas contra a conveniência da Lei em questão, e julgue nocivo ao interesse geral do Império que qualquer Assembléia Provincial, em atenção a interesses locais ou individuais, possa multiplicar o número de comarcas, e impor ao Governo Geral a obrigação de provê-las com Juízes e ao Tesouro Nacional o ônus de pagar-lhes ordenados não pequenos; todavia pensa, à vista da ampla atribuição do $\S 1^{\circ}$ do Art. 10 do referido Ato Adicional, que a Assembléia da Paraíba está no seu direito quando decreta sobre a divisão judiciária da respectiva Província, e que a Lei de que se trata só pode ser revogada pela mesma Assembléia Provincial, mais esclarecida, ou melhor aconselhada. Pelo que é a mesma Seção de parecer, que em quanto não for alterada a divisão decretada na Paraíba, pelo referido meio, não deverá o Governo Imperial expedir ordem alguma a tal respeito, como solicita o VicePresidente. ${ }^{300}$

A questão dos ofícios apareceu também em 1856 no Conselho de Estado Pleno.

Nessa consulta de 1856, foram formulados nove quesitos aos quais a Seção teve de responder - nas palavras do Visconde do Uruguai, em uma consulta "bastante concludente e esclarecedora"301 cujo relator fora Eusébio de Queiroz. A Seção iniciou a sua exposição afirmando necessitar distinguir três categorias de funcionários públicos no Império. A primeira eram os Gerais, sobre os quais as Assembléias Provinciais não

poderes locais ${ }^{298}$. Segundo Lopes, havia na administração da justiça questões relativas aos poderes das províncias para organizar os serviços respectivos, bem como o exame das leis provinciais (desmembramento de comarcas, termos e distritos), que possuía grande repercussão política: mudanças dessa natureza implicavam aumentar ou diminuir poderes de juízes vitalícios e, portanto, favorecer interesses políticos específicos LOPES, J.R.L. Consultas da Seção de Justiça do Conselho de Estado (1842-1889), a Formação da Cultura Jurídica Brasileira. In: Almanack Braziliense n 5 maio/2007. P. 35.

${ }^{299}$ CAROATÁ, J.P.J.S. op.cit. p.490. Resolução de 11 de outubro de 1854.

${ }^{300}$ CAROATÁ, J.P.J.S. op.cit. p.491. Resolução de 11 de outubro de 1854.

301 Ata de 19 de junho de 1856. In: RODRIGUES, J. H. (ORG.) Atas do Conselho de Estado Pleno, Terceiro Conselho de Estado (1850-1857). Brasília: Senado Federal, 1978, p.p. 206-209. 
possuíam qualquer poder de legislar; a segunda consistia nos empregos provinciais e municipais criados por Leis gerais para execução de Leis gerais referentes a objetos sobre os quais as Assembléias Provinciais não possuíam jurisdição, como Juízes de primeira instância, Escrivães, Tabeliães, e em geral os Ofícios de Justiça criados para execução dos Códigos e Leis de organização judiciária ${ }^{302}$; a terceira categoria era composta dos empregos provinciais e municipais, cujas funções eram relativas a objetos sobre os quais podiam legislar as Assembléias Provinciais. Quanto a estes empregos enquadrados na terceira categoria, as Assembléias Provinciais podiam legislar plenamente ${ }^{303}$. Deste esclarecimento inicial, o relatório passou à resposta aos quesitos.

Foram os dois primeiros quesitos perguntados: $1^{\circ}$ - "A disposição do art. 10, $\S$ $7^{\circ}$ do Ato Adicional ( $2^{\mathrm{a}}$ Parte) e art. $2^{\mathbf{o}}$ da Interpretação referem-se aos empregos existentes, ou também àqueles que fossem, de futuro, criados por leis gerais em desempenho das atribuições que competem ao Poder Geral?" $2^{\circ}$ - "Pode o Poder Geral, pelo princípio de que lhe compete a organização judiciária, criar ofícios de Justiça privativos?" ${ }^{304}$ Segundo a resposta da Seção, competia apenas ao Poder Geral criar ofícios privativos. Ainda segundo a Seção, dúvidas da inteligência de algum artigo do Ato Adicional só poderiam ser resolvidas pelo poder geral ${ }^{305}$. Ou seja, ficava claro que interpretar a Lei competia apenas ao Poder Geral.

O terceiro quesito questionava se poderia o Poder Geral, em virtude do mesmo princípio, criar dois ou mais ofícios cumulativos, quando esse número conviesse à administração. Quanto a isto, a Seção respondia que o Poder Geral era autorizado a criar e suprimir ofícios cumulativos e a declarar no Ato de sua criação o número. A diferença, segundo a Seção, consistia em que antes do Ato Adicional esse número não

\footnotetext{
302 A respeito dos empregos públicos citados nesta categoria, a Lei de Interpretação do Ato Adicional reconhecia às Assembléias Provinciais o direito de criar e suprimir numericamente, sendo esta faculdade relativa à que elas possuíam de legislar sobre a divisão civil, judiciária e eclesiástica, todavia sob a condição de não poderem aumentar ou diminuir atribuições, nem alterar sua natureza, competência exclusiva do Poder Legislativo geral.

${ }^{303}$ URUGUAI, V. Estudos Práticos Sobre a Administração de Províncias do Brasil, Volume II. Rio de Janeiro: Typografia Nacional, 1865, p. 17.

${ }^{304}$ Ata de 19 de junho de 1856. In: RODRIGUES, J. H. (ORG.) Atas do Conselho de Estado Pleno, Terceiro Conselho de Estado (1850-1857). Brasília: Senado Federal, 1978, p. 209.

${ }^{305}$ Ata de 19 de junho de 1856. In: RODRIGUES, J. H. (ORG.) Atas do Conselho de Estado Pleno, Terceiro Conselho de Estado (1850-1857). Brasília: Senado Federal, 1978, p. 209.
} 
podia ser alterado por outro poder, mas que devido a ele, as Assembléias Provinciais podiam aumentá-lo ou diminuí-lo ${ }^{306}$.

$\mathrm{O}$ quarto quesito questionava se poderiam as Assembléias Provinciais tornar privativos os Ofícios criados como cumulativos pelo Poder Geral, ou vice-versa, isto é, tornar cumulativos aqueles que o Poder Geral criou como privativos. Quanto a isto, a Seção considerava que, se a Assembléia apenas mudasse o número, mas não a natureza dos Ofícios privativos, estaria em seu completo direito. Segundo a Seção, ofício privativo era o destinado a apenas um funcionário, e cumulativo o que era destinado a muitos. Uma vez estabelecida a distinção, afirma que o número dos ofícios é fixado por maneira puramente acidental, pois a natureza do ofício não pode sofrer alteração pelo aumento ou diminuição do número de ofícios, e nesse caso não poderia ser contestável o direito das Assembléias provinciais de aumentar ou diminuir. Contudo, se o número fosse ligado à natureza das atribuições, as Assembléias não o poderiam nesse caso alterá-los. No entendimento da Seção, cabia ao Poder Legislativo Geral ao criar um ofício, constar se o número era alterável ou não. Fora desta hipótese, contudo, as Assembléias podiam "sem a menor limitação aumentar ou diminuir, o número dos empregos da segunda classe." 307

O quinto quesito perguntava se poderiam as Assembléias Provinciais suprimir absolutamente os Ofícios de Justiça, criados pelo Poder Geral. A Seção respondeu negativamente, pois ofícios criados para execução de leis gerais, constituíam objetos que não estavam sob a jurisdição das Assembléias, portanto, não haveria qualquer possibilidade de legislar sobre eles. Isto equivaleria a anular uma lei geral, poder que, conforme os conselheiros elas não possuíam ${ }^{308}$.

Quanto ao sexto quesito, a Seção era chamada a responder se a anexação ou desanexação dos Ofícios de Justiça não possuía implicações sobre a natureza dos mesmos Ofícios. A este quesito, a Seção respondeu com cinco corolários: primeiro, que este direito estava intimamente ligado ao direito de legislar sobre os casos e forma da

\footnotetext{
306 Ata de 19 de junho de 1856. In: RODRIGUES, J. H. (ORG.) Atas do Conselho de Estado Pleno, Terceiro Conselho de Estado (1850-1857). Brasília: Senado Federal, 1978, p.p. 209-210.

307 Ata de 19 de junho de 1856. In: RODRIGUES, J. H. (ORG.) Atas do Conselho de Estado Pleno, Terceiro Conselho de Estado (1850-1857). Brasília: Senado Federal, 1978, p. 210.

308 Ata de 19 de junho de 1856. In: RODRIGUES, J. H. (ORG.) Atas do Conselho de Estado Pleno, Terceiro Conselho de Estado (1850-1857). Brasília: Senado Federal, 1978, p. 210
} 
nomeação; segundo, que as Assembléias só possuíam este último direito a respeito dos cargos de terceira classe, não podendo legislar anexando ou desanexando os de segunda, ou seja, os que fossem de criação do Poder Legislativo Geral, e cuja competência fosse objeto sobre o qual as Assembléias não poderiam legislar; terceiro, o direito de anexação eventual de ofícios, pelo fato de nomear o mesmo indivíduo para ofícios compatíveis, pertencia ao governo; quarto, o direito de estabelecer como norma das nomeações e anexações os termos do corolário terceiro, pertencia ao governo; quinto, o direito de desanexação dos ofícios que se anexaram por disposição da lei, porém na forma dos corolários terceiro e quarto, competia igualmente ao governo, exceto os direitos particulares adquiridos por nomeações feitas. ${ }^{309}$

O sétimo quesito perguntava se as Assembléias Provinciais poderiam anexar ou desanexar Ofícios de Justiça que o Poder Geral, pelo princípio da organização judiciária, anexara ou desanexara, e se elas também não poderiam também anexar e desanexar a jurisdição quando a fonte do Poder fosse a mesma, isto é, com base no art. $10, \S 7^{\circ}$ do Ato Adicional, e art. $2^{\circ}$ da Lei de 12 de maio de 1840 . A Seção respondeu negativamente, julgando este quesito prejudicado ${ }^{310}$.

O oitavo quesito perguntava se o Decreto de 30 de janeiro de 1834, que regulou os Ofícios de Justiça das vilas novamente criadas, não se considera restaurado desde que a Interpretação do Ato Adicional (art. $2^{\circ}$ ) reduzira as coisas ao status quo anterior às circunstâncias que reclamaram a mesma interpretação. A Seção respondeu afirmando que o dito decreto somente poderia vigorar a respeito dos Termos novamente criados, em que não houvesse designação especial do número.

Por fim, no nono quesito pedia-se à Seção para responder como se deveria proceder a respeito dos Títulos Vitalícios de Ofícios que são depois desanexados pelas Assembléias Provinciais. A Seção julgou este quesito prejudicado, pois o mesmo nega às Assembléias o direito de ordenar estas desanexações.

Sobre isto, afirmava Uruguai nos Estudos Práticos:

\footnotetext{
309 Ata de 19 de junho de 1856. In: RODRIGUES, J. H. (ORG.) Atas do Conselho de Estado Pleno, Terceiro Conselho de Estado (1850-1857). Brasília: Senado Federal, 1978, p.p.210-211.

${ }^{310}$ Ata de 19 de junho de 1856. In: RODRIGUES, J. H. (ORG.) Atas do Conselho de Estado Pleno, Terceiro Conselho de Estado (1850-1857). Brasília: Senado Federal, 1978, p. 211.
} 
As Assembléias Provinciais tem anexado ofícios de Justiça desanexos por leis gerais, tem desanexado outros anexos, tem tornado cumulativos outros declarados privativos e vice-versa. É este um dos assuntos em que tem elas mais freqüentemente tocado, é um daqueles em que mais formigam pretendentes e empenhos aí por essas vilas, onde há pouco que pedir e pouco que dar, muita gente que se quer acomodar em empregos públicos e de dois em dois anos, de quatro em quatro anos, muita dívida eleitoral para pagar. ${ }^{311}$

Ou seja, a atribuição que as Assembléias tinham de legislar sobre ofícios, inclusive no que dizia respeito ao número de comarcas, deixava-as com uma grande arma de negociação com o governo central, pois, para acomodar seus apoiadores, poderiam fazer como fizera a Assembléia da Paraíba no caso aqui mencionado, dobrando o número de comarcas. Poderiam, ainda, no limite, suprimir uma comarca na qual os agentes do governo estivessem na contramão dos interesses da elite provincial, pois ao haver uma troca de gabinete, ou mesmo uma dissolução da Câmara dos Deputados, isso não implicava uma mudança na composição das Assembléias, que não podiam ser dissolvidas. A Assembléia acabava se tornando um embaraço que o Presidente nomeado pelo gabinete demissionário deixava para o seu sucessor.

Ainda em 1854, uma questão referente às sanções do Presidente da Província chegou à Seção de Justiça do Conselho de Estado, sendo Paulino José Soares de Souza seu Relator. Tratava-se da Resolução de 25 de fevereiro de 1854 - "Sobre os ofícios do Presidente da Província de São Paulo, que acompanharam a representação da Assembléia Legislativa da mesma Província acerca do provimento e demissão dos postos da Guarda Nacional e julgamento dos Magistrados"312.

Fora aprovado pela Assembléia Provincial de São Paulo, o projeto que “dispunha que nem a Lei $n^{\circ} 25$ de 12 de março de 1846, nem qualquer outra Lei anterior permitiria a demissão dos Oficiais da Guarda Nacional, conservando estes os mesmos postos." 313 O Presidente da Província de São Paulo negou-se a sancionar este projeto, pois no seu entendimento ele ofendia a Constituição do Império, estabelecendo

\footnotetext{
${ }^{311}$ URUGUAI, V. Estudos Práticos... op.cit. Volume II, p.13.

${ }^{312}$ CAROATÁ, J.P.J.S. op.cit. p. 413.

${ }^{313}$ CAROATÁ, J.P.J.S. op.cit. p. 413.
} 
disposições novas sobre objetos que não eram de competência das Assembléias Provinciais $^{314}$.

Segundo o parecer de Paulino de Souza:

A Seção conforma-se com o procedimento e razões dadas pelo Presidente, que lhe parecem dignas de aprovação. (...) Contudo tem de observar que todo este assunto se acha prejudicado pela adoção e execução da Lei de 19 de setembro de 1850, que deu nova organização à Guarda Nacional do Império. (...) A Seção entende que prevalecem as razões em que se funda o Presidente da Província, e que não foram destruídas na representação daquela Assembléia Provincial, e parecer que a acompanha. (...) Posto que esta decisão não deixe de ser algum tanto extemporânea, visto que o projeto em questão passou na Assembléia Provincial de S. Paulo em abril de 1849, há perto de cinco anos, tendo de dar uma solução a estes papéis, é a Seção de parecer que deve ser aprovado o Procedimento do Presidente da Província de São Paulo, aguardando-se a decisão da Assembléia Geral. ${ }^{315}$

Ou seja, Paulino de Souza concordara com o presidente que não poderia ser aprovada uma Lei que impedisse o governo de obrar livremente a demissão dos oficiais da Guarda Nacional. A reforma da Guarda Nacional em 1850 concentrou as nomeações dos oficiais nas mãos do governo central, acabando com os postos eletivos que ela possuía desde 1831. O governo poderia realizar as nomeações tanto diretamente como por meio dos Presidentes de Província. Novamente, estava colocada a questão de o governo central dispor de cargos nas localidades, aos quais poderia nomear livremente.

A 22 de fevereiro de 1862 foi consultado o Conselho de Estado Pleno sobre as dúvidas do Presidente da Província de Alagoas relativas à atribuição das Assembléias de verificarem os poderes de seus próprios membros. O Presidente duvidava da constitucionalidade da disposição do $\S 4^{\circ}$ das alterações que a Assembléia fizera em seu regimento. Por esta razão, decidiu não publicá-lo, pois não dependia de sanção, segundo o Artigo 13 do Ato Adicional. Perguntava assim ao Governo Imperial como haveria de proceder. Partindo dessa questão, a Seção do Império, de onde subira a questão para o Pleno, sintetizou o problema em dois quesitos: primeiro, se podiam as Assembléias Provinciais impor aos Presidentes uma obrigação como a do referido $\S^{\circ}$ em um ato que não dependesse da sanção do Presidente; segundo, se esse ato ofendia as

\footnotetext{
${ }^{314}$ CAROATÁ, J.P.J.S. op.cit. p. 413.

${ }^{315}$ CAROATÁ, J.P.J.S. op.cit. p. 413. [Grifo Meu]
} 
leis eleitorais que estabeleciam que os deputados provinciais seriam declarados como tais pelas Câmaras Municipais, e não pelos Presidentes. ${ }^{316}$

Diante disto, a Seção resolveu quanto à primeira questão, que era necessário distinguir se as Assembléias Provinciais, nos atos que não dependessem de sanção obravam dentro de suas atribuições constitucionais ou não. Em caso afirmativo, estavam os presidentes obrigados a sancionar, mas no segundo não. Portanto, cabia examinar se a disposição do referido $\$ 4^{\circ}$ era exclusiva das Assembléias para verificar os poderes de seus membros. ${ }^{317}$

Quanto ao segundo quesito, a seção respondia negativamente. A seu ver, a Assembléia alagoana não ofendia a Constituição, e nem as leis eleitorais, pois não transferia das Câmaras Municipais aos Presidentes a atribuição de declarar quem eram os membros da Assembléia, nem de expedir diplomas ${ }^{318}$.

Olinda discordou do Parecer, apresentando voto em separado, pois considerava que as Assembléias não possuíam a competência de legislar sobre eleições. Dizia em seu voto que, pelo art. $6^{\circ}$ do Ato Adicional, as Assembléias tinham o direito de verificar os poderes de seus membros, assim como o de organizar seus regimentos internos $\left(\right.$ Art $\left.11 \S 1^{\circ}\right)$. Contudo, em sua opinião, no que diz respeito à organização dos Regimentos, estavam obrigadas não apenas com a Constituição, mas com as leis gerais em tudo o que não fosse objeto de sua competência. Concluiu afirmando que competia ao Poder Geral regular a apuração dos votos para as Assembléias ${ }^{319}$.

O Marquês de Abrantes e o Visconde de Albuquerque votaram pelo voto separado de Olinda. O Visconde de Abaeté também votou pelo voto separado, alegando que no seu entendimento, a reforma do Regimento decretada pela Assembléia Provincial, era contrária à Constituição, ao Ato Adicional, e "à índole do sistema representativo; e por conseqüência o pior meio de evitar a dificuldade, que se tinha em

\footnotetext{
${ }^{316}$ Ata de 22 de fevereiro de 1862. In: RODRIGUES, J. H. (ORG.) Atas do Conselho de Estado Pleno, Terceiro Conselho de Estado (1857-1864). Brasília: Senado Federal, 1978, p. 156.

${ }^{317}$ Ata de 22 de fevereiro de 1862. In: RODRIGUES, J. H. (ORG.) Atas do Conselho de Estado Pleno, Terceiro Conselho de Estado (1857-1864). Brasília: Senado Federal, 1978, p. 157

${ }^{318}$ Ata de 22 de fevereiro de 1862. In: RODRIGUES, J. H. (ORG.) Atas do Conselho de Estado Pleno, Terceiro Conselho de Estado (1857-1864). Brasília: Senado Federal, 1978, p. 157

${ }^{319}$ Ata de 22 de fevereiro de 1862. In: RODRIGUES, J. H. (ORG.) Atas do Conselho de Estado Pleno, Terceiro Conselho de Estado (1857-1864). Brasília: Senado Federal, 1978, p. 158.
} 
vista remover., ${ }^{, 320} \mathrm{O}$ Visconde de Maranguape votou pelo parecer afirmando que por Lei Geral, os deputados provinciais não podiam ser outros que não os eleitos pelos eleitores dos deputados gerais. Na verificação dos poderes dos deputados alagoanos, a Câmara dos Deputados havia eliminado a votação de alguns colégios eleitorais, reconhecendo a eleição dos que foram eleitos pela maioria dos eleitores de outros colégios. Por isso, considerava que uma posterior apuração feita pelas Câmaras Municipais seria um procedimento sem significado algum. Por esta razão, considerava que a Assembléia de Alagoas havia acertado ao atribuir a si o modo de cumprir uma lei geral na Província, requisitando do Presidente a lista de eleitores já reconhecidos como tais pela Câmara dos Deputados, com o objetivo de que os deputados provinciais não fossem eleitos por outros eleitores que não os que elegeram os Deputados Gerais ${ }^{321}$.

O Visconde do Uruguai votou com o voto separado de Olinda, enfatizando os princípios envolvidos na questão. Concluiu que, mesmo que a medida da Assembléia Provincial fosse conveniente, ela não seria jurídica ${ }^{322}$.

Pimenta Bueno votou pelo parecer, afirmando ser de necessidade salvar os "princípios fundamentais de nossas instituições e leis orgânicas". Dizia o futuro Marquês de São Vicente:

A Lei constitucional declara que não há Assembléia Provincial legítima, se não a que é nomeada pelos mesmos eleitores que nomearam os deputados gerais, e que foram pela Câmara destes considerados legais. Os membros da Assembléia Provincial de que se trata não foram nomeados por tais eleitores e sim por eleitores declarados ilegais; logo tal Assembléia é ilegítima. Ora, é uma máxima não contestada, que a interpretação de uma lei, que dá em conseqüência a violação dessa mesma lei, é má e inadmissível. A inteligência ou interpretação do voto separado dá esse resultado. Para ressalvar uma atribuição da Assembléia Provincial, que aliás não é violada, consagra a violação de um preceito constitucional e reconhece como legítima uma Assembléia ilegal e intrusa. (...) O Visconde de Sapucaí já fez ver claramente que não se transfere apuração alguma ao Presidente da Província. Em relação a esses distritos eleitorais não há que discriminar eleitores legítimos e ilegítimos: todos sem exceção são ilegítimos, e como tais reprovados pela Câmara dos Deputados. A medida adotada por esse artigo do Regimento não demanda pois discriminação, ou apuração; é apenas uma relação nominal de tais eleitores. Ora, essa

\footnotetext{
${ }^{320}$ Ata de 22 de fevereiro de 1862. In: RODRIGUES, J. H. (ORG.) Atas do Conselho de Estado Pleno, Terceiro Conselho de Estado (1857-1864). Brasília: Senado Federal, 1978, p. 160.

${ }^{321}$ Ata de 22 de fevereiro de 1862. In: RODRIGUES, J. H. (ORG.) Atas do Conselho de Estado Pleno, Terceiro Conselho de Estado (1857-1864). Brasília: Senado Federal, 1978, p. 160.

${ }^{322}$ Ata de 22 de fevereiro de 1862. In: RODRIGUES, J. H. (ORG.) Atas do Conselho de Estado Pleno, Terceiro Conselho de Estado (1857-1864). Brasília: Senado Federal, 1978, p. 160.
} 
relação não passa de uma informação; e não sei como se denegue à Assembléia Provincial esse meio de esclarecimento. ${ }^{323}$

Respondendo a Pimenta Bueno, questionou o Visconde do Uruguai se os eleitores já haviam sido aprovados pela Câmara dos Deputados, ou não. Caso não tivessem sido, não poderia o Governo intervir na questão da sua legalidade, competindo exclusivamente à Câmara dos Deputados fazê-lo. Caso a Câmara dos Deputados já houvesse aprovado os eleitores, e os deputados provinciais não tivessem sido eleitos por eles, estaria evidente que não eram deputados, havendo a necessidade de o governo mandar executar a deliberação da Câmara dos Deputados, procedendo à apuração dos eleitores legítimos. Por essa razão, votava com o marquês de Olinda. ${ }^{324}$.

Após esta discussão, escreveu o Visconde do Uruguai ao Marquês de Olinda:

Concordo completamente com o voto justo de V. Exa. e à vista de seu desenvolvimento simples e claro, surpreende-me que os Srs. Sapucaí e Pimenta Bueno pensem do modo contrário. Nenhuma observação tenho a acrescentar. (...) como V. Exa sabe, tem as Assembléias Provinciais legislado sobre eleições, mas não encontro caso semelhante ao presente. Parece que até agora nenhuma lembrou de fazer os seus Regimentos, exemplo exigido porque assim fica o delegado do governo geral privado da única arma que constitucionalmente tem, para preservar a unidade da legislação eleitoral. Vê-se a amplitude que a Assembléia das alagoas dá ao Artigo $6^{\circ}$ do Acto Adicional - na forma de seus Regimentos - que devem restringir à economia interna, e à ordem dos trabalhos e discussões. ${ }^{325}$

Nessa discussão, a respeito da verificação dos poderes dos Deputados Provinciais, estava em questão a possibilidade de o governo, por meio de seu agente (o Presidente da Província) poder contestar de algum modo a eleição para a Assembléia Provincial. Isso era essencial para o funcionamento do sistema do patronato executivo (troca de cargos por apoio), que como vimos no Capítulo 1, foi objeto de discussão entre Uruguai e o Imperador. Era essencial ao governo ter em mãos um instrumento que desse a ele a possibilidade de ajudar seus aliados nas Províncias a se elegerem para as Assembléias, pois isso poderia render dividendos eleitorais ao próprio governo quando necessitasse eleger seus candidatos à Câmara dos Deputados.

\footnotetext{
${ }^{323}$ Ata de 22 de fevereiro de 1862. In: RODRIGUES, J. H. (ORG.) Atas do Conselho de Estado Pleno, Terceiro Conselho de Estado (1857-1864). Brasília: Senado Federal, 1978, p.p. 160-161[Grifo Meu]

${ }^{324}$ Ata de 22 de fevereiro de 1862. In: RODRIGUES, J. H. (ORG.) Atas do Conselho de Estado Pleno, Terceiro Conselho de Estado (1857-1864). Brasília: Senado Federal, 1978, p. 161.

${ }^{325}$ Carta de 25 de junho de 1862 do Visconde do Uruguai ao Marquês de Olinda. IHGB: Lata211A, Pasta 27.
} 
Todavia, a despeito de considerar em vários momentos que as Assembléias Provinciais cometiam diversos males, Uruguai reiteradamente contrariou seus colegas de partido defendendo os direitos das mesmas Assembléias. Ou seja, o mal não era a existência das Assembléias, mas o modo pelo qual elas estavam organizadas e o excesso de poder que Uruguai considerava que elas tinham.

A seguir, veremos como esse debate apareceu nas obras do Visconde do Uruguai.

\section{2 - As Obras de Direito e o Debate sobre CentralizaÇão.}

No dia 31 de maio de 1861, em sessão do Senado, o Visconde de Jequitinhonha apresentou requerimento pedindo para que fosse nomeada uma comissão mista pela Câmara e pelo Senado, em igual número de membros para o exame dos $\S \S 1^{\circ}, 5^{\circ}$ e $6^{\circ}$ do Art. $10^{\circ}$ do Ato Adicional, assim como do $\$ 9^{\circ}$ do Art.11 e dos Arts. 15,16 e 19 da mesma Lei, com vistas à elaboração de um projeto de interpretação ${ }^{326}$.

Pelo Ato Adicional, a competência das Assembléias ficou definida nos Arts.10 e 11 da mesma Lei. Esses dois artigos deixaram praticamente todas as questões municipais a cargo das Assembléias. Os artigos 15, 16 e 19 que Jequitinhonha propunha reformar se referiam respectivamente ao direito do Presidente de negar a sanção a uma lei provincial, devolvendo à Assembléia, mediante exposição de suas razões para que ela decidisse definitivamente; se o presidente entendesse que o projeto era contrário à outra província ou a tratado com nação estrangeira e a Assembléia mantivesse por mais de $2 / 3$, deveria juntamente com as razões apontadas pelo Presidente ser enviado à Assembléia Geral Legislativa que resolvia definitivamente; o presidente teria um prazo de dez dias para negar a sanção, e, caso não o fizesse, estaria entendido que a deu.

Disto, Jequitinhonha elaborou dez quesitos para serem debatidos na Comissão: (1) se as Assembléias poderiam legislar sobre a divisão judiciária, civil e eclesiástica, cujos empregados eram pagos pelo governo geral, sem que este estivesse de acordo; (2) se matéria que já desse contribuição ao governo geral poderia ser novamente onerada

${ }^{326}$ URUGUAI, V. Estudos Práticos... op.cit. p. XIV. 
para o pagamento de tributos à Província; (3) se as Assembléias poderiam criar impostos de exportação; (4) se poderiam taxar gêneros importados de outras províncias, produzidos nelas ou não; (5) se no caso de o Presidente encontrar nas resoluções das Assembléias disposições sobre matérias não contempladas nos arts.10 e 11 do Ato Adicional, ou sobre as restrições que faziam a elas os Arts. 12 e 16, deveria separá-las e proceder sobre elas conforme o Art. $9^{\circ}$ do Ato Adicional, enviando-os ao governo e Assembléia geral para que resolvessem; (6) o que se deveria entender por contribuição direta, cuja repartição pelos Municípios da Província era competência das Assembléias, segundo o $\S 6^{\circ}$ do art. $1^{\circ}$ do Ato Adicional; (7) como deveriam ser contados os dois terços exigidos nos Arts. 15, 16 e 19; (8) se no caso de os quesitos sobre impostos serem decididos negativamente, caberia o estabelecimento de quotas da renda geral às Províncias, baseadas ou não na proporção da arrecadação geral que ali se fizesse; (9) se o direito dos Presidentes de suspenderem a execução das Leis Provinciais era extensivo às Leis que não dependessem de sanção dos mesmos; e, por fim, (10)deveria a comissão responder qual era o poder competente para o estabelecimento da forma do processo, segundo a qual deveria ser decretada pelas Assembléias a suspensão ou demissão dos magistrados ${ }^{327}$.

Segundo o Visconde do Uruguai, este requerimento apresentado por Jequitinhonha foi aprovado pelo Senado e remetido à Câmara dos Deputados, onde foi discutido e também aprovado ${ }^{328}$. Nomeada, em julho de 1861, pela Câmara dos Deputados e pelo Senado uma comissão para resolver sobre os quesitos de Jequitinhonha encaminhados pelo Senado, ela "não apresentou trabalho algum, e dispersou-se." 329

Contudo, antes que Jequitinhonha formulasse esses quesitos que seria,, conforme veremos mais adiante, retomados por Uruguai, Pimenta Bueno dedicara parte de seu Direito Público, de 1857, a tratar de muitas das questões propostas à Comissão de Assembléias do Senado para debate em 1861. Segundo Pimenta Bueno, a existência das Assembléias tinha por base o art.71 da Constituição, que consagrava a todo cidadão o direito de intervir nos negócios de sua Província. Segundo o referido

\footnotetext{
${ }^{327}$ URUGUAI, V. Estudos Práticos... op.cit. p.p. XV-XVI.

${ }^{328}$ URUGUAI, V. Estudos Práticos... op.cit. p. XVI.

${ }^{329}$ URUGUAI, V. Estudos Práticos... op.cit. p. XVI.
} 
autor, as Assembléias ocupavam-se dos interesses provinciais, que eram diferentes dos gerais, pois não afetavam a nação inteira. Em sua visão, o Poder Legislativo Provincial, não era uma delegação da soberania nacional, como era o caso da Assembléia Geral Legislativa. Tratava-se de uma representação puramente provincial, autorizada simplesmente para as atribuições que a Assembléia Geral havia lhes concedido. Pimenta Bueno propunha a criação de uma segunda câmara nas Províncias, cuja eleição seria semelhante à do Senado. Seus membros deveriam ser escolhidos a partir de listas tríplices, geradas a partir de eleição, para que a Coroa, por intermédio do Presidente da Província escolhesse quem assumiria o cargo. Para Pimenta Bueno, essa segunda Câmara, deveria ter uma duração maior do que a legislatura provincial, além de renovar-se apenas parcialmente. A criação da segunda câmara, do modo como postulava, tinha claramente o objetivo de minar o poder das Assembléias Provinciais ${ }^{330}$.

Conforme vimos na discussão acerca dos ofícios de justiça, as Assembléias possuíam, pelo $\S 1^{\circ}$ do art.10 do Ato Adicional o, direito de legislar sobre a divisão civil, judiciária e eclesiástica. Quanto a isso, Pimenta Bueno considera que "o Ato Adicional em mais de uma disposição foi obra de precipitação"331. Em sua opinião, somente o poder central, autor dos códigos e das leis processuais deveria ter essa jurisdição, pois a divisão civil e eclesiástica faziam parte de um todo, que era a organização judiciária do país, e "dar parte desse todo a um e outra parte para a outrem é não querer uma ordem regular, uma concepção completa e homogênea" ${ }^{\text {"32 }}$. Pimenta Bueno concorda com a disposição do art.12 da Lei de Interpretação do Ato Adicional, que impediu que as Assembléias alterassem a natureza de cargos criados por leis gerais, mantendo, porém a atribuição de modificar-lhes o número, aumentando ou diminuindo, anexando ou desanexando ofícios de justiça. Todavia, ainda pondera que deveria haver mecanismos para evitar abusos quanto a essa atribuição, que não permitissem que uma

\footnotetext{
330 PIMENTA BUENO, J. A. Direito Público Brasileiro e Análise da Constituição do Império. In: KUGELMAS, E. Marquês de São Vicente. São Paulo, Editora 34, 2002, p.p. 220-234. Segundo Miriam Dohlnikoff, na opinião de Pimenta Bueno, a segunda câmara compensaria a limitação do presidente em corrigir os erros das Assembléias Provinciais. DOHLNIKOFF, M. O Pacto Imperial: Origens do Federalismo no Brasil. São Paulo: Globo, 2005. p.105.

${ }^{331}$ PIMENTA BUENO, J. A. Direito Público ... op.cit. p.239.

${ }^{332}$ PIMENTA BUENO, J. A. Direito Público ... op.cit. p.238.
} 
Assembléia reduzisse o seu número de comarcas a uma só, nem que as fizesse multiplicar desordenadamente ${ }^{333}$.

Pimenta Bueno também considera que o Presidente da Província deveria ser considerado como parte integrante do Poder Legislativo Provincial. Por essa razão, além do já exposto no Capítulo 2, defendia a criação dos Conselhos de Presidência de voto consultivo para auxiliarem os Presidentes de Província na sua função legislativa de sancionar ou vetar resoluções das Assembléias Provinciais. Seriam "uma imagem, ou representação subalterna do Conselho de Estado" 334 e, com sua força moral, seriam um corretivo ao que considerava serem as más disposições do Ato Adicional. Por fim, Pimenta Bueno defende que os presidentes, mediante autorização do governo imperial, tivessem a atribuição de dissolver as Assembléias Provinciais. ${ }^{335} \mathrm{Ou}$ seja, as propostas de Pimenta Bueno em relação às Assembléias iam todas no sentido de minimizar seu poder.

Nos Estudos Práticos, Uruguai discordava da proposta de Pimenta Bueno de criar uma segunda câmara nas Províncias, por considerar que isso tornaria a administração das Províncias ainda mais dispendiosas. Uruguai cita o exemplo dos Estados Unidos, onde os Estados possuíam uma segunda câmara legislativa. Contudo, segundo Uruguai, dada as atribuições que possuíam as Províncias brasileiras, que eram diferentes dos Estados norte-americanos, considera que a adoção desse modelo estrangeiro seria prejudicial devido à sua incompatibilidade com a realidade brasileira. ${ }^{336}$ É verdade que Uruguai não chega a mencionar a proposta de Pimenta Bueno, que não era seu interlocutor específico neste ponto e cujo objetivo era aliás bem diverso do de instituir no Brasil o modelo norte-americano. Porém, apesar dessa divergência quanto à conveniência de uma segunda câmara, ambos defendem a diminuição do poder das Assembléias Provinciais.

Uruguai também reclamava da situação na qual as legislações provinciais se encontravam, apesar de louvar a Lei de Interpretação. Em sua visão, o grande serviço prestado pela lei de Lei de Interpretação de 1840 fora o de simplificar e facilitar a

\footnotetext{
${ }^{333}$ PIMENTA BUENO, J. A. Direito Público ... op.cit. p.238-243.

${ }^{334}$ PIMENTA BUENO, J. A. Direito Público ... op.cit. p.257.

335 PIMENTA BUENO, J. A. Direito Público ... op.cit. p.261.

${ }^{336}$ URUGUAI, V. Estudos Práticos... op.cit. p. 30.
} 
reforma da administração da Justiça e da Guarda Nacional. Afirmava que a Lei de 3 de dezembro de 1841 e a Lei $\mathrm{n}^{\circ} 602$ de 19 de setembro de 1850 (que dera nova organização à Guarda Nacional), impediam as Assembléias Provinciais de montarem seu antigo sistema, ou seja, o das chamadas leis de prefeitos como fizera, por exemplo, a Assembléia de Pernambuco à época da regência ${ }^{337}$.

Segundo Uruguai, o sistema praticado no Brasil de as leis aprovadas pelas Assembléias Legislativas Provinciais poderem ser revogadas pelo Poder Legislativo geral mostrava-se ineficiente ${ }^{338}$. Para embasar sua opinião, expunha todas as leis provinciais revogadas desde a aprovação do Ato Adicional, chegando ao seguinte quadro, de 1835 a 1848 haviam sido revogadas somente 21 leis provinciais. De 1848 a 1864, conforme os Estudos Práticos, não fora revogada nenhuma lei provincial, mesmo que fosse visivelmente contrária à Constituição. Uruguai considerava impossível que isso se devesse à falta de zelo e inércia da Assembléia Geral Legislativa, dado o grande número de legislaturas que se sucederam ao longo de 30 anos. Contudo, ponderava que o Poder Legislativo Geral, por ser político e se reunir durante apenas quatro meses ao ano, tinha diversas questões políticas importantes a tratar no período de funcionamento, impedindo uma revisão mais eficiente das leis provinciais. Como exemplo das questões que ocupavam a maior parte das sessões, Uruguai cita o caso da resposta à Fala do Trono (que segundo ele tomava um quarto do tempo de reunião anual), além dos debates sobre orçamento, fixação de forças, requerimentos, justificativas pessoais, em suma as atividades centrais do exercício de suas atribuições como Poder Legislativo, o que deixava pouco tempo para rever as leis de 20 Assembléias Provinciais ${ }^{339}$.

A seu ver, o exame e a revogação das leis provinciais era assunto de "diuturno expediente". O problema de ser tratado como questão política era, entre outras coisas, a pouca experiência e necessidade de afirmação de políticos mais jovens.

Os homens que se julgam exclusivamente liberais, quando novéis e inexperientes, tem tendência para chamar todos os negócios, ainda os mais pequenos, embora da competência do Executivo ou Judiciário, à Representação Nacional. Dominados pelo ciúme e pela desconfiança de outro qualquer Poder, do qual não fazem parte, acreditam que fora de uma Assembléia política e eletiva não pode haver justiça e garantias. Os

\footnotetext{
${ }^{337}$ URUGUAI, V. Estudos Práticos... op.cit. p. XVII.

${ }^{338}$ URUGUAI, V. Estudos Práticos... op.cit. p. 419.

${ }^{339}$ URUGUAI, V. Estudos Práticos... op.cit. p. 424.
} 
diários das primeiras e antigas Cortes Gerais e Constituintes de Portugal e da nossa Assembléia Constituinte, as atas da nossa Câmara dos Deputados do ano de 1827 e seguintes fornecem numerosos e frisantes exemplos. Ora, ainda há muita gente cujo liberalismo ainda é desse tempo.

Não advertem que querem o impossível, no estado das sociedades modernas, e que o único remédio é estudar e organizar bem um país, cultivar as suas instituições, aperfeiçoá-las, cotidianamente e para isso estudar e trabalhar muito. ${ }^{340}$

Segundo Uruguai, não deveria haver a necessidade de a Assembléia Geral ter que revogar as leis provinciais, se os presidentes não sancionassem leis ofensivas à Constituição e aos interesses de outras Províncias. Ou seja, considerava que os presidentes de Província não cumpriam sua tarefa, delegando-a à Assembléia Geral. Em sua visão também pesava a questão da pouca punição que os Presidentes recebiam nessas ocasiões e, principalmente, o problema das diversas nomeações para cargos, que eram feitas corriqueiramente para a obtenção de apoio aos candidatos do governo. "As simples advertências são raras nesses casos. O essencial são as nomeações e demissões de Guarda Nacional, Subdelegados, etc. etc."341.

Contudo, Uruguai descartava a hipótese de retirar da Assembléia Geral Legislativa, "a grande sentinela da União", a atribuição de revogar leis províncias. Segundo o Visconde, seria necessário que o governo geral tivesse a atribuição de, a partir de um determinado prazo, revogar as deliberações dos Presidentes que

\footnotetext{
${ }^{340}$ URUGUAI, V. Estudos Práticos... op.cit. p. 425. Conforme indica Eide Sandra Azevedo Abreu, a chamada Liga Progressista formara-se em 1861 para as eleições legislativas daquele ano. Sua ascensão ao Poder Executivo central ocorreu em 1862, com o gabinete de 24 de maio, presidido por Zacarias de Góes e Vasconcelos. Sua duração entretanto foi curta, pois caiu seis dias depois. Há várias razões para a queda. Primeiramente, o Imperador desde a praieira se recusava a dissolver a Câmara dos Deputados e, segundo Abreu, deixara claro a Zacarias que ele deveria conseguir obter maioria, ou seja, que a Câmara não seria dissolvida em favor do Ministério. Ao apresentar seu programa, Zacarias mencionou que pretendia realizar alterações na Lei de 3 de dezembro de 1841. Isso gerou uma forte oposição conservadora, diante da qual o gabinete não resistiu. Dada a demonstração de força dos conservadores, o Imperador chamou o Marquês de Olinda para formar um novo gabinete. Com a saída de Olinda em 1864, Zacarias foi novamente chamado a formar gabinete. Nesse mesmo ano, Uruguai ainda escrevia os Estudos Práticos. Essas críticas aos homens novéis, era justamente à nova geração de políticos imperiais que ascendiam ao poder junto com a Liga. VER: ABREU, E.S.A. O Evangelho do Comércio Universal. O Desempenho de Tavares Bastos na Liga Progressista e no Partido Liberal (1861-1862). Tese de Doutoramento apresentada ao Departamento de História do Instituto de Filosofia e Ciências Humanas da Universidade Estadual de Campinas, 2004, p.p. 110-129.

${ }^{341}$ URUGUAI, V. Estudos Práticos... op.cit. p.p. 426-427.
} 
sancionavam tais leis, sujeitando seu ato ao conhecimento da Assembléia Geral para que essa decidisse de forma definitiva ${ }^{342}$.

Uruguai compara a situação do Brasil com a dos Estados Unidos onde esse poder de revogação pertencia ao Poder Judiciário. Mas, conclui que o modelo norteamericano não era aplicável ao Brasil e que "o ato adicional adotou os corretivos que nos eram aplicáveis e mais conformes à nossa organização",343.

Todavia, o fato de a revogação pela Assembléia Geral estar conforme à nossa organização não o impedia de clamar por uma reforma do Ato Adicional. Para ele, era fundamental que o governo Imperial pudesse suspender uma sanção dada pelo Presidente, que julgasse nociva aos direitos de outras Províncias ou a tratados com nações estrangeiras, submetendo depois a decisão final à Assembléia Geral Legislativa.

É indispensável uma pequena reforma, porém utilíssima no Ato Adicional. Quando o Presidente da Província sanciona uma lei, vigora ela por mais que seja ofensiva da Constituição, dos direitos das outras Províncias e dos Tratados com nações estrangeiras. Vigora enquanto a Assembléia Geral a não revoga. Vale mais, pode mais o Agente do Governo Geral, o Presidente, do que o mesmo Governo Geral. (...) É preciso que o Governo Geral possa reformar a decisão de seu Agente, Presidente da Província; que lhe cria dificuldades em assuntos que dizem respeito à Constituição, aos direitos de outras Províncias e a Tratados. Fica suspensa a questão afeta ao Poder Legislativo Geral. Uma lei provincial, por exemplo, ofende um Tratado com nação estrangeira. (...) A nação estrangeira reclama. O Governo Geral, com o qual se entende, não pode suspender a execução da lei provincial sancionada pelo seu Agente. Somente a Assembléia Geral pode dar tardio remédio. A Assembléia Geral ainda não revogou em algum dos casos. ${ }^{344}$

Vemos com isso que Uruguai desejava uma redução no espaço de atuação das Assembléias Provinciais. Nessa proposta de reforma do Ato Adicional fica evidente que ele não admitia a possibilidade de que elas fossem soberanas. Caso sua proposta fosse adotada, seria muito mais fácil, para o governo intervir em questões provinciais. Também com isso, a Assembléia Provincial montada pelo Ministério anterior não embaraçaria em demasia a ação do Presidente de Província, agente do Ministério.

O debate sobre centralização política no Império também envolveu Aureliano Cândido Tavares Bastos. Gabriela Nunes Ferreira parte do princípio de que tanto para Uruguai como para Tavares Bastos a ausência de espírito cívico e o baixo nível de

\footnotetext{
${ }^{342}$ URUGUAI, V. Estudos Práticos... op.cit. p. 428.

${ }^{343}$ URUGUAI, V. Estudos Práticos... op.cit. p. 430.

${ }^{344}$ URUGUAI, V. Estudos Práticos... op.cit. p. XLV.
} 
civilização do povo eram uma realidade. Porém, interpretavam esta situação de modos diferentes no que tange à aplicabilidade ao Brasil de instituições liberais aos moldes anglo-saxões.

A referida autora estabelece algumas diferenças entre estes dois publicistas do Império. Tavares Bastos propunha uma monarquia federativa. Dentre suas principais idéias destacam-se: a criação de Senados Provinciais; a elegibilidade dos presidentes de Província, pois considerava que isto traria um duplo benefício estabilizando a administração das Províncias e retirando-lhes a função de cabo eleitoral; a proposta de criação de um secretariado provincial e de delegar às Assembléias Provinciais a eleição dos senadores. Uruguai, por sua vez, defendia a nomeação dos presidentes de Província e a criação de conselhos administrativos nas províncias nomeados pelo poder central ${ }^{345}$. Para Tavares Bastos, esses conselhos trariam inúmeros malefícios, tais quais aumentar a influência do governo central; dificultar o progresso dos negócios, cujo andamento era demasiado lento; entorpecer a ação do presidente e diminuir-lhe a responsabilidade, além de minar as Assembléias Provinciais ${ }^{346}$.

Aqui, é preciso estabelecer uma diferença importante entre Tavares Bastos e Uruguai. As propostas de Tavares Bastos de que tratamos acima nos levam a inferir uma visão da província como uma unidade política autônoma, ou seja, com disputas de poder e interesses internos, alheios ao poder central. Toda a sua proposta de reforma aproxima-se do modelo de descentralização dos Estados Unidos. Uma simples frase do Visconde do Uruguai mostra a diferença entre ambos. Diz ele nos Estudos Práticos: "A província não é uma divisão política, mas administrativa." ${ }^{347}$ Conforme vimos no Capítulo 2, Uruguai deixa claro nas Bases e no Ensaio que considera o modelo francês mais apropriado às condições brasileiras do que o modelo anglo-saxão. Porém, é importante lembrar que neste último livro, Uruguai fez uma revisão da centralização política que ele ajudou a montar na década de 1840, embora isso não significasse, a nosso ver (como trataremos a seguir), que ele estivesse se contradizendo. De certo

${ }^{345}$ Ver: URUGUAI, V. Ensaio Sobre o Direito Administrativo. in: CARVALHO, J.M. (ORG), Visconde do Uruguai. São Paulo: Editora 34, 2002. p.p. 212-218

${ }^{346}$ Ver: TAVARES BASTOS, A.C. A Província: Estudo Sobre a Descentralização no Brasil. Brasília: Cia. Editora Nacional, 1975. p. 74

${ }^{347}$ URUGUAI, V. Estudos Práticos Sobre a Administração de Províncias do Brasil. Rio de Janeiro: Typographia Nacional, 1865. p. XI 
modo, Uruguai concordava com Tavares Bastos quanto ao problema dos presidentes de Província tornarem-se cabos eleitorais. Para Uruguai, eles eram "considerados pelos Ministérios como agentes políticos e chefes de eleições, não como administradores. Os Ministérios pouco duram; pouco duram os presidentes de Província também". 348

Isso é significativo, pois, para Uruguai, o fato de a província ser uma divisão administrativa deveria implicar que os presidentes nomeados pelo poder central (ou seja, a princípio não envolvidos nas disputas locais) agissem como administradores. A administração pública para Uruguai tinha por função dirigir os interesses sociais (quer gerais, quer locais). Não caberia, assim, à sua função se tornarem agentes políticos, mas sim auxiliares da administração geral. À época das reformas centralizadoras do Regresso, um dos principais argumentos dos saquaremas era justamente o fato de o Ato Adicional de 1834 ter concentrado o poder nas capitais das províncias, possibilitando, inclusive, a criação das chamadas leis de prefeitos, por parte de algumas Assembléias Provinciais (como a de São Paulo), que estabeleciam funcionários por nomeação da Província nos municípios. Estas leis foram alvo de várias críticas, como mostra o parecer da Comissão de Assembléias Provinciais da Câmara dos Deputados Sobre a Interpretação do Ato Adicional. O parecer, do qual Paulino é signatário afirma que estas leis vinham de uma má interpretação do $\$ 7^{\circ}$ do Art.10 do Ato Adicional que autorizava as Assembléias a legislar sobre a criação e supressão de empregos provinciais e municipais. Contudo, o parecer afirmava não ser admissível que em função disto os prefeitos, agentes criados por leis provinciais, usurpassem funções policiais e judiciárias $^{349}$.

Em 1865, Uruguai afirmava que "Não temos nas províncias verdadeiras municipalidades. Foram entregues amarradas às Assembléias Provinciais., 350 Interessante diante disso, que, no Ensaio, Uruguai se colocou em defesa das municipalidades, deixando clara sua admiração pelas instituições liberais anglosaxônicas:

\footnotetext{
${ }^{348}$ URUGUAI, V. Estudos Práticos ... op.cit. p. VII

${ }^{349}$ Parecer da Comissão das Assembléias Provinciais da Câmara dos Deputados de 10 de julho de 1937 sobre a Interpretação do Ato Adicional in: CARVALHO, J.M. (org.), Visconde do Uruguai. São Paulo: Editora 34, 2002, p.p. 524-534.

${ }^{350}$ URUGUAI, V. Estudos Práticos... op.cit. p. IX
} 
É contudo na municipalidade que reside a força dos povos livres. As instituições municipais são para a liberdade o que as escolas primárias são para a ciência; põem a liberdade ao alcance do povo, fazem com que aprecie o seu gozo tranqüilo e habituamno a servir-se dela. Sem instituições municipais pode uma nação dar-se um governo livre, mas não tem o espírito da liberdade. ${ }^{351}$

Apesar de a defesa das municipalidades aparecer claramente expressa no Ensaio, Tavares Bastos não deixou de associar as idéias do Visconde do Uruguai às de Pimenta Bueno a respeito da centralização, criticando-os por isto:

O mal é a centralização, e eles [Pimenta Bueno e Uruguai] querem combater o mal esmagando a autonomia das províncias, pulverizando estas grandes regiões, que a história constituiu e que a lei fundamental reconheceu. Eles querem que, onde há a liberdade do Ato Adicional, existe de agora em diante a tirania dos prefeitos e a letargia dos departamentos. Esses conservadores do antigo regime, que assim pensam, tem muita razão; para que eles reinem de novo, é preciso dividir por uma vez as forças coligadas de certas províncias que sacudiram o julgo das oligarquias. ${ }^{352}$

Porém, é importante não deixar que esta defesa das municipalidades e admiração pelas instituições políticas inglesas e norte-americanas nos leve a pensar que o que Uruguai pretendia era instituí-las no Brasil. No último capítulo do Ensaio Sobre o Direito Administrativo, Uruguai expõe de modo mais claro a sua posição. Admira a organização destes países, mas suas instituições não eram transplantáveis para o Brasil. O melhor modelo para países em que o espírito público não se encontrava desenvolvido, como na Inglaterra e nos Estados Unidos, seria então o francês. Para Uruguai, a Revolução fizera com que um país que vivera até então sob o julgo absolutista experimentasse repentinamente a liberdade, o que levava a abusos. Fato semelhante ocorrera no Brasil no início da Regência. Assim, a França fornecia o melhor exemplo de como garantir direitos ao cidadão e evitar os abusos que trazia o excesso de liberdade em um local onde não estava consolidada uma cultura de respeito mútuo aos direitos dos demais membros da sociedade.

Em trecho das Bases reproduzido no Ensaio, Uruguai afirmava que o selfgovernment não era um talismã que pudesse ser usado por todos. Em sua visão, ele decorria do hábito, da educação, e do costume, não podendo ser estabelecido por leis.

\footnotetext{
${ }^{351}$ URUGUAI, V. Ensaio Sobre o Direito Administrativo. in: CARVALHO, J.M. (ORG), Visconde do Uruguai. São Paulo: Editora 34, 2002. p.p. 492

352 TAVARES BASTOS, A.C. Cartas do Solitário, op.cit. p. 48
} 
Citando Sá de Miranda, escreveu: "Não valem as leis sem costume, Vale o costume sem lei." 353

Tratando do mesmo tema no Ensaio, Uruguai fala da conveniência do selfgovernment no Brasil:

Isto não tira que seja possível e muito conveniente, no desenvolvimento e reforma das nossas instituições administrativas, ir dando àquela parte de self-government que elas encerram mais alguma expansão temperada com ajustados corretivos, habituando assim o nosso povo ao uso de uma liberdade prática, séria e tranqüila, preservando sempre o elemento monárquico da Constituição, porque no fim das contas, é para aqueles povos que nela nasceram e foram criados essa forma de governo, rodeada de garantias e instituições livres, a que pode assegurar uma liberdade sólida, tranqüila e duradoura. ${ }^{354}$

Mesmo afirmando que apenas o sistema francês era aplicável ao Brasil, Uruguai considerava ser necessário "dar mais largas ao self-government entre nós, reservada sempre ao poder central aquela fiscalização e tutela que ainda mais indispensáveis são em países nas circunstâncias do nosso, porém de modo que essa fiscalização e tutela não embaracem o andamento dos negócios, principalmente dos pequenos"355.

No projeto das Bases, o que estava em questão era a capacidade do governo de fazer sentir sua ação nas localidades. Com as municipalidades colocadas sob a tutela das Assembléias Provinciais, o governo central não tinha uma garantia de que se faria presente. Não é à toa que o próprio Uruguai definiu o Estado brasileiro com a metáfora de que se tratava de uma grande cabeça com braços pequenos. Assim, conceder uma autonomia tutelada às municipalidades seria um meio de quebrar ou de pelo menos concorrer de modo mais eficaz com o poder que tinham as Assembléias Provinciais. Quanto à situação dos municípios, vimos no Capítulo 2 que Uruguai discordava do fato de que nem o governo geral, e nem seus presidentes, possuíam agentes administrativos nos municípios, pois as Câmaras eram exclusivamente de eleição popular, assim como seus presidentes. Com o intuito de remediar os inconvenientes que resultavam da falta de ação dos presidentes nas localidades, buscando colocar mais próximo um centro de ação que melhor pudesse conhecer e remediar suas necessidades, Uruguai apontava que poderiam ser criados territórios, nome dado às áreas recém-

\footnotetext{
${ }^{353}$ URUGUAI, V. Bases ... op.cit. p.6.

${ }^{354}$ URUGUAI, V. Ensaio ... p.498. [Grifo Meu]

${ }^{355}$ URUGUAI, V. Ensaio ... p.504.
} 
incorporadas nos Estados Unidos, pois a criação de uma nova província envolvia a criação de mais 50 ou 60 cargos de alto escalão, sendo que as Assembléias Provinciais constantemente criavam novas comarcas, termos e distritos ${ }^{356}$. Uruguai ainda afirmava que uma nova divisão de províncias não seria a garantia de que a ação do governo pudesse chegar, independentemente de agentes intermediários, a todos os pontos.

Estas considerações, não o explicam inteiramente, mas ajudam a entender o pensamento de Uruguai a respeito do tema. A ação do governo central era difícil de ser sentida nas localidades, tuteladas pelas Assembléias Provinciais, havendo, assim, a necessidade de capilarizar o Estado Imperial. Porém, mais do que isso, ele defendia que o governo central concedesse paulatinamente autonomia às municipalidades, conforme o povo fosse se educando na condução dos próprios negócios. Municípios mais autônomos significavam menor poder das Assembléias Provinciais sobre eles. Isto leva Gabriela Nunes Ferreira a considerar que o interesse de Uruguai em defender a liberdade municipal era evitar que interesses encastelados na Província dominassem a vida política local, com a formação de uma rede de poder e lealdade que escapasse ao governo central. Para a autora, a existência de uma entidade política autônoma quebraria, na visão de Uruguai, o vínculo fundamental que deveria ligar o governo às localidades ${ }^{357}$.

Quanto a essa questão, a autora recupera o terceiro título dos Estudos Práticos:, "Relação entre Poder Provincial e Poder Geral: meios de combater os abusos das Assembléias Provinciais", que considera central para o debate sobre a centralização, pois dizia respeito ao "meios de preservação e defesa com que o Ato Adicional armou os poderes geral e provincial para se defenderem, reprimir, nulificar os excessos e abusos das Assembléias Provinciais, contendo-as na sua órbita constitucional". Segundo Ferreira, caso uma lei fosse aprovada pela Assembléia, o presidente poderia negar a sanção se a julgasse contrária aos interesses da Província. Neste caso, ele voltaria à Assembléia, que poderia mantê-la por 2/3 dos votos de seus membros. Nesta última hipótese, o presidente deveria sancionar a lei que lhe fosse reapresentada.

\footnotetext{
${ }^{356}$ URUGUAI, V. Bases ... op.cit. p.p.6-8.

357 FERREIRA, G.N. Centralização e Descentralização no Império: o Debate Entre Tavares Bastos e Visconde de Uruguai. São Paulo: Editora 34 e Departamento de Ciência política da USP, 1999, p. 119. .
} 
Segundo a autora, Uruguai afirma que em seu art.16, o Ato Adicional rendeu uma homenagem ao princípio do self-government, ao reconhecer nas Assembléias Províncias os poderes mais indicados para julgar ${ }^{358}$.

Nos Estudos Práticos, conforme exposto acima, Uruguai culpa os presidentes de Província de não cumprirem sua obrigação constitucional de negar sanção a leis provinciais consideradas nocivas. Em suas palavras:

Não vão administrar. Vão fazer eleger este, excluir aquele outro, fazer, concertar, consolidar ligas, gastam-se em breve tempo, e quase sempre descontentes, e descontentes seus protetores, entregam a outros instrumentos as pobres províncias mais enredadas do que estavam em um progresso de parcialidades e ódios Não são delegados do imperador, como quer a Constituição, são delegados de partidos ou para melhor das suas oligarquias ou diretórios" Imbuídos de outros interesses que não o bem de suas províncias, os presidentes, por incompetência administrativa ou má fé, deixam de cumprir a atribuição definida no Ato Adicional, de "suspender a publicação das leis provinciais, nos casos e pela forma marcados nos artigos 15 e 16. (art. 24, § 3.) ${ }^{359}$

Ivo $\operatorname{Coser}^{360}$ considera os saquaremas, e em especial do Visconde do Uruguai como centralizadores, denominando seus contendores federalistas. Segundo Miriam Dohlnikoff, mesmo Bernardo Pereira de Vasconcelos, grande inspirador de Uruguai era favorável ao arranjo institucional que consagrava a autonomia provincial, mas se recusava a chamá-lo de federação ${ }^{361}$. Dohlnikoff mostra como Uruguai também não era totalmente oposto a esse sistema que se estabelecera no Império em 1834. Segundo ela, para o Visconde, o problema principal estava em garantir um centro capaz de articular a unidade e assegurar os interesses comuns. Entretanto, a centralização política

358 FERREIRA, G.N. Centralização... op.cit. p.p. 108-110. Para Ferreira, a solução proposta por Uruguai era inspirada no sistema belga, conforme nota-se no fim das Recordações Históricas que abrem os Estudos Práticos, estaria em reforçar a relação de tutela entre o governo central e o presidente de província, permitindo ao governo do Rio de Janeiro, uma vez ouvido o Conselho de Estado, a faculdade de revogar as deliberações de seus delegados até que na Assembléia Geral fosse tomada uma decisão definitiva sobre o assunto. FERREIRA, G.N. Centralização... op.cit. p.111.

${ }^{359}$ URUGUAI, V. Estudos Práticos Sobre a Administração de Províncias do Brasil, Rio de Janeiro, Typographia Nacional, vol. 1, p. XLIV [Grifo Meu]. Podemos ver nessa passagem novamente colocada a questão eleitoral. Mesmo considerando o patronato executivo um mal necessário, Uruguai considerava que ao se tornarem agentes com a missão de fazer uma eleição simpática ao Ministério, os presidentes deixavam de cumprir o seu papel de administradores e mesmo de agentes do governo, pois tornavam-se agentes de partido. Vemos também na passagem citada, que Uruguai em sua crítica menciona claramente a liga.

${ }^{360}$ COSER, I. op.cit.

${ }^{361}$ DOHLNIKOFF, M. op.cit. p.66. 
não necessitava ser acompanhada da administrativa ${ }^{362}$. De acordo com Dohlnikoff, no entender de Uruguai a descentralização administrativa já estava consagrada pelo Ato Adicional, devendo ser reajustada somente em vista de não colocar em risco a centralização política ${ }^{363}$, ou seja garantir a divisão de atribuições para que os governos provinciais não invadissem a esfera do governo central. Dohlnikoff também faz um apanhado das definições de federalismo de Wiliam Ricker ${ }^{364}$, Preston King ${ }^{365}$ e Daniel Elazar $^{366}$ pondo em relevo uma questão essencial para nossa discussão que é o fato de o termo federalismo não poder ser tomado somente como sinônimo de governo descentralizado. Segundo a referida autora, o arranjo institucional que se estabeleceu no Império, assim como a defesa da centralização política feita pelos saquaremas tinham elementos destas definições. Por isso, o debate político sobre centralização no Brasil imperial, no qual Uruguai esteve envolvido, não pode ser apresentado como entre centralizadores e federalistas.

Pelo projeto das Bases, oriundo do pedido por um projeto para melhorar a organização das províncias, percebemos que, com a autonomia municipal por ele defendida não haveria a necessidade de criação de novas Províncias e de Assembléias para tutelar os municípios Com a difusão da civilização eles seriam educados para

\footnotetext{
${ }^{362}$ DOHLNIKOFF, M. op.cit. p.p.143-144.

${ }^{363} \mathrm{Um}$ tema bastante caro aos saquaremas era a separação entre política e administração. Na visão de Ilmar Rohloff de Mattos, o pensamento do Visconde do Uruguai não deixa de ser uma síntese do pensamento dos saquaremas a respeito do Poder Administrativo. Em sua visão, mesmo quando Uruguai aparece sublinhando o caráter apolítico da administração pública, mais se revela a concepção de poder de governo dos saquaremas, pois a administração pública sendo parte do Estado, subordinava-se à estrutura ao poder de que o Estado dispunha. Partindo de Tocqueville, Uruguai estabelecia dois tipos de centralização: a política e a administrativa. A primeira significava concentrar o poder de dirigir os interesses comuns a todas as partes da nação. A segunda dizia respeito ao poder de dirigir os negócios particulares de cada parte. Ver: MATTOS, I.R. O Tempo Saquarema. São Paulo: Hucitec, 1987, p.p. 195-196

${ }^{364}$ Segundo Dohlnikoff, para Riker o que definia o federalismo era a divisão de atribuições entre governo central e governos regionais, não importando o grau de centralização e descentralização. DOHLNIKOFF, M. op.cit. p. 287.

365 Para King de acordo com a autora também não poderia ser definido como centralização ou descentralização. A federação seria o arranjo institucional adotado como estratégia para a construção do Estado, sendo sua marca distintiva a existência de um nível ventral e um nível regional de governo. DOHLNIKOFF, M. op.cit. p.288.

${ }^{366}$ Conforme exposto no Pacto Imperial, federação para Elazar seria um modelo de organização política vinculando unidades distintas em um sistema político global, permitindo que cada um mantivesse sua integridade política fundamental. De acordo com a autora, Elazar diferencia centralização de nãocentralização. Descentralização seria uma delegação de poderes feita pelo governo central, podendo ser por ele revogada a qualquer momento. $\mathrm{O}$ federalismo implicaria uma divisão espacial do poder, além da representação das unidades federativas no legislativo nacional. DOHLNIKOFF, M. op.cit. p.290.
} 
tratarem dos próprios negócios. O que Uruguai deixa entender é que o caminho para isto seria a centralização política, com o governo central conduzindo o processo. Ilmar Rohloff de Mattos atenta para a questão da instrução pública. Para ele, esta era uma das maneiras mais significativas de construir a relação entre o Estado e a $\mathrm{Casa}^{367}$, forjando a unidade do Império ${ }^{368}$. No Relatório Provincial de 1835, Rodrigues Torres afirma que os conhecimentos adquiridos nas Escolas de Primeiras Letras eram indispensáveis para tratar não somente dos negócios domésticos, mas também para desempenhar com esmero todos os deveres do cidadão. Em sua opinião, "fora uma tirania que o Estado impusesse a seus membros obrigações sem lhes dar ao mesmo tempo meios de bem as conhecer e cumprir"369. O Ato Adicional deixara a instrução pública a cargo das províncias. Aqui, é importante ressaltar que quando Paulino Soares de Souza exerceu a Presidência da Província do Rio de Janeiro, foi promulgada e lei de 12 de janeiro de 1837, regulando a instrução primária e interditando-a a pretos africanos, ainda que livres e libertos ${ }^{370}$. Isto é fundamental, pois marca o limite do self-government que Uruguai defendia que fosse paulatinamente concedido. Quem deveria ser educado era a chamada boa sociedade, as elites locais que convinha atrair para a órbita do Estado; a mesma elite que se encarregaria de deixar escravos e homens livres pobres no seu devido lugar. Tratava-se, segundo a concepção de Mattos, de trazer o governo da casa para junto do Estado, de modo que pudesse ser tutelado e, em diversos casos, invadido, ou seja, o governo do Estado poderia intervir em questões que outrora estavam sob a jurisdição de particulares.

\footnotetext{
${ }^{367}$ Esta distinção entre governo da Casa e governo do Estado é feita por Ilmar Rohloff de Mattos em $O$ Tempo Saquarema. De acordo com Mattos, governar a Casa era a um só tempo governar a família, onde estavam inclusos os escravos e o exercício do monopólio da violência naquilo que de acordo com Mattos a historiografia de fundo liberal convencionou chamar de poder privado. Governar o Estado, para Mattos, "consistia, pois, em não só coibir as exagerações daqueles que governavam a casa, tanto no que diz respeito ao mundo do governo, quanto no que tange ao mundo do trabalho, mas em sobretudo empreender as tarefas que eram entendidas como transcendentes às possibilidades daqueles, entre as quais avultava a de propiciar a continuidade dos monopólios que fundavam a classe. Governar o Estado eram no fundo e no essencial, elevar cada um dos governantes da Casa à concepção de vida estatal." MATTOS, I.R. op.cit. p.p. 119-120.

${ }^{368}$ MATTOS, I.R. op.cit. p. 258.

${ }^{369}$ APUD: MATTOS, I.R. op.cit. p. 258.

370 A Constituição de 1824, Art. 179 declarava a instrução primária gratuita a todos os cidadãos. Entretanto, no caso desta lei, a questão colocada era quem eram os cidadãos. Conforme veremos em outro capítulo, os saquaremas não eram favoráveis a franquear a cidadania para africanos ainda que libertos.
} 
Isto se relaciona com o que Mattos considera ter sido a dupla tarefa dos saquaremas: difundir a ordem e manter a civilização. $O$ primeiro ponto significava a manutenção da sociedade dividida entre senhores e escravos, baseada no latifúndio. Difundir a civilização significava, além da formação do povo, trazer senhores locais para a esfera do Estado, subordinando-os à sua autoridade. ${ }^{371}$ Significava quebrar o monopólio de poder que exerciam, sendo neste ponto os saquaremas bastante eficazes, pois a documentação de Seção de Justiça mostra quantos conflitos locais passaram a ser arbitrados pelo Estado e não mais por outros tipos de expediente.

O Visconde do Uruguai ao escrever suas obras propunha diversas reformas. Como tratado no Capítulo 2, as Bases continham um projeto de reforma administrativa, com vistas a organizar o contencioso administrativo em primeira e segunda instância. Nos Estudos Práticos o foco era o Ato Adicional, e a necessidade de reformá-lo. Nesta obra, Uruguai reclamava do fato de a Assembléia Geral por dezesseis anos não ter revogado nenhuma Lei Provincial, sendo que o Conselho de Estado anualmente as revia. A elaboração de seus livros era conseqüência da experiência que acumulara nas instituições políticas das quais fazia parte, pois como se vê, os temas de suas obras já estavam presentes nas discussões de que participou como Senador e como Conselheiro de Estado.

Confrontando essa discussão historiográfica com a leitura da documentação, não concordamos que a defesa da centralização política fosse um fim em si mesmo. Também não concordamos com a dicotomia estabelecida por Coser entre federalistas e centralistas. O que estava em questão era como potentados locais poderiam ser atraídos para a órbita do Estado, que aparecia como um concorrente de seu poder. O aumento do raio de atuação do Estado poderia se dar de forma orgânica, com o auxílio de outras esferas de governo, uma vez que as atribuições de cada uma estivessem bem delimitadas, e, o governo central garantisse sua supremacia sobre as demais esferas. A centralização poderia ser a maneira encontrada de forjar outra organização do Estado Nacional, de garantir que os grandes proprietários tivessem seu poder pessoal reduzido em detrimento do Estado.

\footnotetext{
${ }^{371}$ MATTOS, I.R. O Tempo Saquarema. São Paulo: Hucitec, 1987. p.p. 282-283.
} 
A despeito das divergências expressas no Conselho de Estado Pleno e no encaminhamento das propostas nas obras, tanto Uruguai quanto Pimenta Bueno têm a minimização dos poderes das Assembléias Provinciais como o ponto central de suas propostas a respeito da centralização política. Mesmo a defesa que Uruguai faz das municipalidades tinha endereço certo: o poder das Assembléias. Também essa mesma defesa aparece muito mais como retórica se tomarmos o conjunto de suas idéias a respeito do tema. Aqui, torna-se importante levar em consideração o caráter político de suas obras, escritas em uma época na qual havia forte contestação ao modelo de Estado montado pelos saquaremas. Considerando o quadro político da década de 1860, Uruguai não poderia defender que as Assembléias tivessem um poder menor sem buscar atrair alguma simpatia dos que defendiam uma maior autonomia em relação ao governo central. Com isso, Uruguai realizava uma operação discursiva, na qual a defesa das municipalidades aparecia como justificativa para levar a cabo seu projeto de reduzir o poder das Assembléias e aumentar o controle do Rio de Janeiro sobre o resto do país. Importante lembrar que, conforme vimos no Capítulo 1, o Imperador deplorava o sistema do patronato executivo. Ora, em diversas passagens transcritas dos Estudo Práticos vemos Uruguai também se posicionar contrariamente a esse sistema que gerava "muita dívida eleitoral a pagar". Isso relaciona-se ao fato de os saquaremas terem perdido espaço político e, ser necessário angariar alguma simpatia por parte do próprio monarca. No diálogo com Pedro II, que vimos no primeiro capítulo, Uruguai defendia o patronato executivo. Nos Estudo Práticos tece críticas. Contudo, difícil pensar que se trata de uma repentina mudança de opinião, principalmente por parte de um político em sua idade madura. Talvez buscasse apoio do Imperador para, pelo menos em parte, implantar seu programa de reformas. A experiência já havia lhe mostrado que não renderia frutos insistir com o monarca na questão do patronato executivo.

Após a análise da documentação, na qual ele claramente defendia que as Assembléias pudessem dispor livremente sobre a força policial, inclusive criando jurisdições de primeira e segunda instância para julgar seus soldados, não se pode simplesmente afirmar que seu objetivo então era o de acabar com as Assembléias, ou mesmo negar a esfera provincial de poder. Uruguai inclusive se posicionou 
contrariamente aos seus colegas de partido quanto a essa questão. O Visconde defende que elas tenham suas atribuições claramente definidas. O que estava em questão para Uruguai, era o fato de considerar que as Assembléias detinham uma grande parcela de poder que, em sua visão, conviria diminuir em favor do governo central, ou pelo menos fazer com que fosse controlada pelo governo. Em suma, podemos afirmar que suas obras, escritas na década de 1860 mostram como dialogando com o contexto daquela época, Uruguai propunha claramente mudanças administrativas como um meio para atingir seu objetivo político. 


\section{Capítulo 4 - Contrabando, Propriedade e Direitos: O Problema da ESCRAVIDÃo}

O presente capítulo visa a discutir as concepções de Paulino José Soares de Souza, Visconde do Uruguai, a respeito da escravidão e dos direitos dos escravos. Este tema ocupou-o desde seu início na política ministerial, até seus últimos anos de vida quando se dedicava a suas atribuições de senador e conselheiro de Estado. Contudo, não tratou do tema em seus livros, fonte fundamental para o entendimento de suas idéias sobre centralização política e organização da justiça, mas expressou suas idéias em seus relatórios ministeriais, no legislativo geral e no Conselho de Estado.

$\mathrm{Na}$ reflexão a este respeito, a perspectiva apontada por Rafael de Bivar Marquese sobre o liberalismo escravista atlântico (1820-1860) $)^{372}$ e a de Tamis Peixoto Parron $^{373}$ sobre a íntima ligação dos saquaremas com o comércio ilegal entre 1831 e 1850 e mesmo com a própria instituição do cativeiro, fornecem importantes elucidações.

Conforme indica Tamis Parron, os primeiros estudos sobre escravidão no Brasil remontam ao movimento abolicionista e ao início da República, destacando-se as obras de Joaquim Nabuco, O abolicionismo de 1883, de Rui Barbosa, A emancipação dos escravos, de 1884, e a de Evaristo de Morais, A campanha abolicionista, de $1924^{374}$. O ponto comum a essas obras, a despeito das diferenças, seria o pressuposto de que a consolidação do Estado Nacional inevitavelmente levaria ao fim do cativeiro. A década de 1960 viu despontar diversas pesquisas a respeito do tema, em que se destacam os trabalhos de Florestan Fernandes, Octavio Ianni, Fernando Henrique Cardoso, Fernando Novais e Emília Viotti da Costa, tendo como ponto comum o estabelecimento

\footnotetext{
${ }^{372}$ MARQUESE, R.B. Governo dos Escravos e Ordem Nacional: Brasil e Estados Unidos (1820-1860) in: Jancsó, I. (org.) Brasil: Formação do Estado e da Nação. São Paulo: Hucitec, 2003. Sobre a perspectiva atlântica do liberalismo escravista ver também: BERBEL,M.R. MARQUESE, R.B. PARRON, T.P. Escravidão e Política. Brasil e Cuba, 1780-1850. São Paulo: Hucitec e Fapesp, 2010.

${ }^{373}$ PARRON,T.P. A Política da Escravidão no Império do Brasil, 1826-1865. Dissertação de Mestrado apresentada ao Programa de Pós-Graduação em História Social, FFLCH/USP. São Paulo, 2009.

${ }^{374}$ PARRON,T.P. A Política da Escravidão ... op.cit. p.6.
} 
de nexos entre o capitalismo e a escravidão ${ }^{375}$. Outros trabalhos como os de Leslie Bethell e de Robert Conrad colocam grande ênfase no papel de diplomacia britânica e sua pressões sobre o Império do Brasil para liquidar com o cativeiro, relegando a um papel secundário a dinâmica interna que levou à abolição, que seriam respostas às cobranças externas $^{376}$. Em linha oposta à de Bethell, João José Reis, Robert Slenes, Flávio Gomes e Sidney Chalhoub depositam grande ênfase no papel dos escravos como agentes sociais do processo que levou à abolição ${ }^{377}$. Os estudos de Jaime Rodrigues e Beatriz Mamigonian também focaram na ação dos cativos, recuperando os debates parlamentares das décadas de vinte e trinta do século XIX, sem, contudo, levar suficiente em consideração as pressões britânicas ${ }^{378}$. Por fim, há os trabalhos conhecidos por seu grande enfoque na dinâmica política do Império como os de Paula Beiguelman, José Murilo de Carvalho, Ilmar Rohloff deMattos e Jeffrey D. Needell. Apesar das diferenças de interpretação da história política, tocam no tema da escravidão, possuindo como ponto comum, cada um ao seu modo, a discussão das relações entre o Parlamento e a escravidão no Brasil ${ }^{379}$.

\footnotetext{
${ }^{375}$ PARRON,T.P. A Política da Escravidão ... op.cit. p.7. Ver também: COSTA, E.V. Da Monarquia à República: Momentos Decisivos. São Paulo, UNESP, 2007. IANNI, O. As metamorfoses do escravo. São Paulo: Difusão Européia do Livro, 1962; CARDOSO, F.H. Capitalismo e escravidão no Brasil meridional: o negro na sociedade escravocrata do Rio Grande do Sul. São Paulo: Difusão Européia do Livro, 1962; FERNANDES, F. O negro no mundo dos brancos. São Paulo: Difel, 1971; e NOVAES, F.A. Portugal e Brasil na crise do Antigo Sistema Colonial(1777-1808). São Paulo, Hucitec, 2001.

${ }^{376}$ PARRON,T.P. A Política da Escravidão ... op.cit. p.7. Ver também: BETHELL, L. A abolição do tráfico de escravos no Brasil: a Grã-Bretanha, o Brasil e a questão do tráfico de escravos, 1807-1869. São Paulo, EDUSP, 1976; e CONRAD, R. Os últimos anos da escravatura no Brasil. Rio de Janeiro, Civilização Brasileira, 1978.

377 PARRON,T.P. A Política da Escravidão ... op.cit. p.8. REIS, J. J. Rebelião escrava no Brasil. A história do levante dos Malês em 1835. São Paulo, Companhia das Letras, 2003. CHALHOUB, S. Visões da liberdade: uma história das últimas décadas da escravidão na corte. São Paulo: Companhia das Letras, 2001. SLENES, R. 'Malungo, Ngoma vem': África coberta e descoberta no Brasil.in: Revista $U S P$ n $^{\circ} 12$. São Paulo: EDUSP, 1991/1992, pp. 48-67.

378 PARRON,T.P. A Política da Escravidão ... op.cit. p.8. RODRIGUES, J. O infame comércio: propostas e experiências no final do tráfico de africanos para o Brasil (1800-1850). Campinas, UNICAMP, 2000. BEATRIZ, G.M. To be a liberated African in Brazil: labour and citizenship in the nineteenth century. Tese de Doutorado. Waterloo, Ontario, Canada, 2002.

${ }^{379}$ PARRON,T.P. A Política da Escravidão ... op.cit. p.9. MATTOS, I.R. O Tempo Saquarema. Editora Hucitec, São Paulo, 1987. CARVALHO, J.M. A Construção da Ordem. Rio de Janeiro: Civilização Brasileira, 2003. CARVALHO, J.M. Teatro de Sombras. Rio de Janeiro: Civilização Brasileira, 2003. NEEDELL, J.D. The Party of Order. The Conservatives, the State, and Slavery in the Brazilian Monarchy, 1831-1871. California: Stanford University Press, 2006. BEIGUELMAN, P. Formação Política do Brasil. São Paulo: Pioneira, 1967.
} 
No tocante ao Visconde do Uruguai, que nos interessa em especial, existe uma idéia, por parte de historiadores como José Murilo de Carvalho e Ivo Coser, de que haveria um silêncio sobre o tema em seu pensamento. José Murilo de Carvalho, a despeito de destacar que, para Paulino, pesavam as relações familiares com os cafeicultores fluminenses, pondera que não é possível reduzir a atuação do Visconde do Uruguai à sua plena determinação por laços pessoais, pois ele se preocupava com o equilíbrio entre poder e liberdade, com a garantia limitada de direitos civis. Mesmo assim, para José Murilo de Carvalho, a questão dos laços não é desprezível, pois deveria sentir no mínimo um grande constrangimento quando era colocado diante da necessidade de lidar como político com temas vitais para esse grupo. Face ao constrangimento, "o visconde escolheu o silêncio como tinham escolhido o silêncio os autores da Constituição de $1824 " 380$. Por essas razões, Carvalho considera que as idéias de Uruguai não constituem somente uma defesa dos interesses dos proprietários do Rio de Janeiro. Para o autor, isto significaria uma caricatura de sua ação e sua obra. Ainda assim, destaca o fato de o tema da escravidão não ter sido tratado nos livros de Uruguai $^{381}$. Segundo Carvalho, Paulino "não falou em classes sociais, em senhores de terra, em trabalhadores, em escravos. Estas palavras não aparecem no Ensaio "382.

Em linha semelhante, Ivo Coser também destaca o silêncio de Uruguai, limitando-se, no tocante ao cativeiro, a fazer uma análise discursiva centrada particularmente no discurso que Uruguai fizera na Câmara dos Deputados na qualidade de ministro dos Negócios Estrangeiros quando da abolição do tráfico negreiro ${ }^{383}$.

Todavia, como se verá neste capítulo, Paulino Soares de Souza manifestou-se sobre o tema em diversas ocasiões. E, se não é possível reduzir suas idéias à "mera defesa dos interesses dos proprietários do Rio de Janeiro", cabe não esquecer que, em diversos momentos, Uruguai foi assíduo defensor dos interesses desse grupo.

De acordo com Marquese, desde meados do século XVIII a escravidão vinha sendo encarada por boa parte da comunidade letrada atlântica como um entrave ao

\footnotetext{
${ }^{380}$ CARVALHO, J.M. Entre a Autoridade e a Liberdade. in: CARVALHO, J.M. (ORG), Visconde do Uruguai. São Paulo: Editora 34, 2002 p. 42.

${ }^{381}$ CARVALHO, op.cit. p. 39.

${ }^{382}$ CARVALHO, op.cit. p. 39

${ }^{383}$ COSER, I. Visconde do Uruguai, Centralização e Federalismo no Brasil, 1823-1866. Belo Horizonte: Editora UFMG, 2008, p.p. 211-221.
} 
progresso humano $^{384}$. Ainda no século XVIII, começou a figurar na ordem do dia dos Estados Nacionais. Houve em São Domingos a revolta dos negros e mestiços livres que pretendiam desfrutar dos direitos de cidadania da Revolução Francesa, que extravasou para o mundo dos escravos e foi acentuada por guerras inter-metropolitanas no mundo colonial $^{385}$, culminando na independência do Haiti. Nos Estados Unidos, os Estados do Norte aprovaram nesta época diversas leis que iam desde a abolição do tráfico, até uma abolição gradual do cativeiro. Nos Estados do Sul, no mesmo período, a única medida antiescravista que teve êxito foi a autorização a particulares de emanciparem seus cativos sem necessidade de uma prévia permissão do governo, isso na Virgínia e em Maryland ${ }^{386}$. Portugal também promoveu reformas anti-escravistas, sob o governo do Marquês de Pombal, dentre as quais podemos destacar o fim do tráfico negreiro para o reino (1761); extensão da igualdade civil aos nativos americanos (1755) e asiáticos (1761); e o início da abolição gradual do cativeiro no reino a partir de $1773^{387}$.

No Brasil pós-independência, isso suscitou grandes polêmicas. Conforme indica Parron, as instruções eleitorais de 1821 para a eleição de deputados para as Cortes de Lisboa incluíam libertos e homens livres de cor na prerrogativa do voto. Informados pela experiência fundadora do Haiti, os deputados brasileiros defenderam a cidadania destes grupos, pois estavam convencidos de que sua exclusão seria um motivo para que se decidissem por brigar revolucionariamente por seus direitos ${ }^{388}$. Conforme veremos mais adiante, o Visconde do Uruguai pensava de maneira semelhante; para ele, a defesa de alguns direitos dos cativos, em que não estava inclusa a manumissão, era um meio de prevenção de novas revoltas. Trata-se de um caso claro em que os quadros mais amplos do Direito (a Constituição) e da política (seu contexto de elaboração) definiram o sentido jurídico e social das decisões pontuais acerca da conduta diária dos cativos.

Parron aponta que, após a Independência, a cor da pele não figurava na Constituição de 1824 como atributo necessário ao exercício dos direitos políticos. A

\footnotetext{
${ }^{384}$ MARQUESE, R.B. op.cit. p.252.

${ }^{385}$ DUBOIS, L. A Colony of Citizens. Chaplel Hill: University of North Carolina Press, 2004.

${ }^{386}$ MARQUESE, R.B. op.cit. p. 255

${ }^{387}$ PARRON, Tamis, A Nova e Curiosa Relação (1764): escravidão e Ilustração em Portugal Durante as Reformas Pombalinas in: Almanack Braziliense (Recurso Eletrônico) Volume 8. São Paulo: Instituto de Estudos Brasileiros da Universidade de São Paulo, Segundo Semestre de 2008.

${ }^{388}$ PARRON,T.P. A Política da Escravidão no Império do Brasil, 1826-1865. Dissertação de Mestrado apresentada ao Programa de Pós-Graduação em História Social, FFLCH/USP. São Paulo, 2009, p.26.
} 
Constituição, em seu art. $6^{\circ}$, deferiu cidadania a todos os escravos nascidos no país - até o momento da Independência - que fossem contemplados com a alforria, ainda que fossem descendentes diretos de africanos. Percebendo que se ignoram medidas e discursos em favor da escravidão, o autor lança um questionamento importante:

Como é que o Estado nacional, cabe perguntar, sustentou o tráfico negreiro por um quarto de século com tais idéias? Será que os súditos do império brasileiro eram esquizofrênicos e desorientados, dizendo isto e fazendo aquilo, mirando para um lado e acertando o outro? Ou será que eles eram tão materialistas e mesquinhos, que se entregavam apenas à necessidade de "braços", prescindindo de conviçcões íntimas e de um sistema valorativo correspondente? ? $^{389}$

Como afirma o autor, a defesa da escravidão no século XIX, assim como a do tráfico negreiro se escorou no liberalismo, de modo que essa "triste embora eficaz fusão ajuda a esclarecer o fenômeno da dupla expansão da liberdade e do cativeiro, da riqueza e da miséria, num país que ansiava (e ainda anseia) por pertencer ao futuro da civilização e do progresso humano., ${ }^{390}$

O ponto principal abordado por Parron e que aqui nos interessa é a ligação do Partido Conservador com o contrabando de africanos e, conseqüentemente, com a própria instituição do cativeiro. Afirma o autor que a consolidação partidária no Brasil coincidiu com as primeiras defesas públicas do tráfico e da escravidão desde os escritos dos anos vinte. A partir dos debates parlamentares, estabelece a ligação entre o comércio ilegal de africanos e a formação dos partidos políticos imperiais. Além disto, seu trabalho mostra a relação entre enunciação parlamentar, reformas políticas e “articulação social de grandes contrabandistas brasileiros do século XIX, nomeadamente os fazendeiros e negociantes do eixo Rio de Janeiro-Vale do ParaíbaMinas Gerais.” ${ }^{391}$ Parron também destaca que houve bastante silêncio de parte da historiografia sobre o tema, juntamente com uma ênfase superlativa das idéias antiescravistas de José Bonifácio. Conforme veremos a seguir, o mesmo acontece com o Visconde do Uruguai no que tange à monumentalização de seu discurso na Câmara

\footnotetext{
${ }^{389}$ PARRON,T.P. A Política da Escravidão... op.cit. p. 27.

${ }^{390}$ PARRON,T.P. A Política da Escravidão... op.cit. p. 27.

391 PARRON,T.P. A Política da Escravidão... op.cit. p.90. Ver também: SALLES,R. E o vale era o escravo: Vassouras, século XIX. Senhores e escravos no coração do Império. Rio de Janeiro: Civilização Brasileira, 2008; LENHARO, A. As tropas da moderação: o abastecimento da Corte na formação política do Brasil, 1808-1842. São Paulo : Símbolo, 1979; MATTOS, I.R. O Tempo Saquarema. São Paulo: Hucitec, 1987.
} 
dos Deputados em 15 de julho de 1850 contra a continuidade do tráfico negreiro e clamando apoio do Legislativo para sua extinção.

Parron mostra que, após a abdicação, o contrabando negreiro não proporcionava capital político. O ex-Imperador era identificado como inimigo da lei e os moderados apresentavam-se como seus fiéis executores ${ }^{392}$. Entretanto, transformações no cenário internacional, com a abolição da escravidão nas colônias britânicas, encarecendo o preço de seus produtos, aliadas ao contexto de aprovação do Ato Adicional, que parecia garantir relativa estabilidade interna, propiciaram uma mudança. Diante de um mercado mundial em franca expansão, o contrabando surgiu como meio de alavancar as plantations do Vale do Paraíba fluminense. A partir disto começavam as críticas à Lei de 7 de novembro de 1831 que proibira o tráfico transatlântico. Após a reforma constitucional de 1834, no contexto da eleição para o cargo de Regente Único, o grupo derrotado na eleição iniciou uma pronunciada defesa do contrabando. Destacavam-se, então, as figuras mais proeminentes do futuro Partido Conservador: Honório Hermeto Carneiro Leão, Bernardo Pereira de Vasconcelos, Joaquim José Rodrigues Torres, Eusébio de Queiroz e Paulino José Soares de Souza. As pautas deste grupo contemplavam, por um lado, as chamadas leis centralizadoras do Regresso, mas também, como afirma o referido autor, a defesa do contrabando e da propriedade escrava ilegal $^{393}$.

A abolição do tráfico negreiro intercontinental não foi uma medida de fácil implementação. O Bill Alberdeen, entre outras coisas, autorizava o Alto Tribunal do Almirantado Inglês a julgar os navios brasileiros empregados neste comércio. Neste contexto, a Inglaterra intensificou suas pressões, que já vinham desde o período joanino, para que o Brasil acabasse com o comércio de africanos. A partir de 1845, os navios de guerra britânicos empreenderam diversos apresamentos em águas territoriais brasileiras e em alguns casos até em terra, o que resultou em problemas diplomáticos entre os dois países. O governo se viu dividido entre a pressão estrangeira e a pressão interna, pois além dos traficantes, havia o interesse dos fazendeiros, aliados dos saquaremas. Os conservadores, por muito tempo, atribuíram a continuidade do

\footnotetext{
392 PARRON,T.P. A Política da Escravidão... op.cit. p.96.

${ }^{393}$ PARRON,T.P. A Política da Escravidão... op.cit. p.101
} 
comércio negreiro à opinião pública, modo eficaz de travestir suas opiniões ${ }^{394}$. Isto não significa que, de modo geral, não houvesse descontentamentos com as constantes violações ao território por parte dos cruzeiros britânicos.

Em meio a esse contexto de pressões anti-tráfico, ascendeu ao poder o gabinete conservador de 29 de setembro de 1848, que passou a contar com Paulino José Soares de Souza à frente do ministério dos Negócios Estrangeiros a partir de 8 de outubro de 1849. Sua gestão teve uma atuação importantíssima, pois além de lidar diretamente com as pressões britânicas, enfrentou a grande dificuldade de convencer o Parlamento a aprovar o projeto que culminou na chamada Lei Eusébio de Queiroz. José Antonio Soares de Souza afirma, em A Vida do Visconde do Uruguai, que seu bisavô tomara a iniciativa, já decidido desde o início a liquidar com o tráfico. Na verdade, o biógrafo simplesmente repete muito do que Paulino de Souza falava de si mesmo nos discursos parlamentares dessa época.

O livro mencionado dá grande ênfase ao discurso de 15 de julho de 1850, proferido por Paulino na Câmara dos Deputados. Tal discurso, tão comentado na obra de José Antônio, é usado por alguns autores como exemplo das idéias anti-escravistas do futuro Visconde do Uruguai ${ }^{395}$. Contudo, Paulino Soares de Souza só foi tratar de ir à tribuna - convencer a Câmara - nove meses depois de assumir os Negócios Estrangeiros, o que sugere não ter sido a questão do tráfico, a princípio, prioridade do gabinete.

\subsection{DIREITO E ESCRAVIDÃo}

As Américas viveram diversas experiências de liberalismo escravista. Brasil, $\mathrm{Cuba}^{396}$ e Estados Unidos tiveram leis que de alguma forma buscaram regular a

\footnotetext{
${ }^{394}$ PARRON,T.P. A Política da Escravidão... op.cit.

${ }^{395}$ CARVALHO, J.M. Entre a Autoridade e a Liberdade ... op.cit. e COSER, I. Visconde do Uruguai ... op.cit.

${ }^{396}$ Durante o século XIX, a ilha manteve o seu status colonial, porém, assim como em outros países do continente houve uma legislação a respeito dos escravos. Em 4 de julho de 1870 as Cortes espanholas aprovaram a chamada Lei Moret, que libertava os escravos com idade superior a 60 anos e as crianças nascidas de ventre escravo. Além disto, a lei estabelecia que todo escravo vítima de crueldade excessiva poderia requerer a sua liberdade. Ver: SCOTT, Rebeca, J. A Emancipação Escrava em Cuba, A Transição para o Trabalho Livre, 1860-1899. São Paulo: Paz e Terra, 1991.
} 
instituição do cativeiro. As Américas enfrentaram o desafio de criar nações liberais independentes nas quais houvesse escravidão ${ }^{397}$.

Como aponta Rafael Marquese, os debates em torno do problema da escravidão na nova ordem nacional norte-americana confluíram para os debates da Constituição Federal. Antes de sua promulgação, as votações no Congresso Continental (em 1784 e 1785) para decidir se os novos territórios ao norte do rio Ohio e ao leste do Mississipi teriam ou não escravos negros polarizaram os representantes dos estados do Norte e do Sul. Na Convenção Constitucional, o tema da escravidão negra foi examinado nas pautas centrais da representação política e da tributação. Havia consenso a respeito da taxação dos escravos, mas não quanto a se eles deveriam ser considerados como parte da população para determinar o número dos representantes de cada estado no Congresso Nacional. Por fim, ficou estabelecido que em cada estado um escravo seria contado como equivalente a 3/5 de uma pessoa livre. Para Marquese, a Constituição aprovada cm 1787 acabou por sancionar integralmente a instituição, fornecendo proteção decisiva para a propriedade dos senhores de escravos ${ }^{398}$.

O programa antiescravista da Ilustração européia também foi difundido no Brasil no contexto da emancipação política e da fundação do Estado nacional, sendo a figura de José Bonifácio de Andrada e Silva paradigmática nesse aspecto. Em sua Representação Sobre a Escravatura, de 1823, encontram-se recomendações para se iniciar o processo de abolição gradual da escravidão no Brasil, que pressupunha enorme intromissão do Estado na soberania doméstica dos senhores. Entre suas propostas destacam-se: o fim do tráfico negreiro intercontinental para quatro ou cinco anos após a promulgação da Constituição; possibilidade legal da compra da alforria por livre ação do escravo; o direito legal do cativo ao pecúlio; a determinação e aplicação das punições físicas pelo poder público; o direito de o escravo reclamar perante o Estado o mau-trato físico e demandar a mudança de senhor e determinação pública das

\footnotetext{
${ }^{397}$ Houve ainda experiências mais peculiares como foi o caso da Jamaica. País independente e já sem escravidão, viu em 1865 em Morant Bay eclodir uma revolta de negros contra as sentenças cruéis emitidas pelos magistrados locais. Com o agravamento das tensões, a Jamaica optou pela volta de seu status colonial. A Assembléia da Jamaica votou a sua própria extinção. Ver: FONER, E. Nada Além da Liberdade: A Emancipação e Seu Legado. Rio de Janeiro: Paz e Terra, 1988, p.p. 52-53.

${ }^{398}$ MARQUESE, R.B. op.cit. p.p. 255-256.
} 
horas de trabalho a serem extraídas do cativo ${ }^{399}$.

No Brasil imperial, diferentemente da experiência norte-americana, não houve a promulgação de um código negro que unificasse todas as leis sobre o tema. O que houve foram diversas leis bastante específicas, que, em geral, se voltavam-se ao controle dos escravos. De acordo com Marquese, o fato de a escravidão negra não figurar expressamente na Constituição de 1824, mas estar suposta no conteúdo de seu artigo 179 (que tratava do direito à propriedade e era evocado constantemente por senhores em contendas judiciais com seus escravos), constituiu amparo legal à instituição, do mesmo modo que as normas penais do Código Criminal de 1830 voltadas especificamente para os escravos ${ }^{400}$. Nesse mesmo ano, Antonio Pereira Rebouças ${ }^{401}$ propôs um projeto de Lei que regulamentava a compra da alforria por parte dos escravos, que sequer chegou a ser discutido ${ }^{402}$.

Segundo Manuela Carneiro da Cunha, o silêncio da lei positiva no tocante à relação senhor-escravo dava a entender a existência de uma "divisão do controle político entre o Estado e os particulares no Brasil da época. O controle dos escravos, a não ser em casos de insurreições e, eventualmente, de assassinatos, ficava a cargo dos senhores" ${ }^{403}$. Entretanto, vale dizer que muito da legislação sobre escravidão vigente à época acabava por ser uma invasão do domínio do senhor. Após a revolta dos malês, em 1835, foi aprovada como lei de exceção a Lei de 10 de junho de 1835, cujo objetivo era punir com a morte sem direito a recurso

\footnotetext{
${ }^{399}$ José Bonifácio de Andrade e Silva. Representação à Assembléia-Geral Constituinte e Legislativa do Império do Brasil sobre a escravatura, in: DOHLNIKOFF, M. (Org.), Projetos para o Brasil. São Paulo: Companhia das Letras, 1998, p.p. 65-78.

${ }^{400}$ MARQUESE, R.B. op.cit. p. 256

${ }^{401}$ Antonio Pereira Rebouças nasceu em 1798 no Recôncavo Baiano, filho do Alfaiate português Gaspar Pereira Rebouças e de Rita dos Santos, provavelmente uma liberta. Sem grandes recursos materiais e autodidata, obteve em 1821 licença para advogar na Bahia. Líder no movimento de independência na Bahia, galgou diversas posições na política imperial. Foi deputado e advogado do Conselho de Estado. Caindo no ostracismo político após 1848, obteve licença para advogar junto à Relação da Corte, tornando-se um advogado de grande prestígio na capital do Império. Afastou-se completamente de suas funções a partir de 1870 devido à cegueira, falecendo em 1880 na Corte. Figura paradigmática do liberalismo escravista, sua maior preocupação de acordo com Keila Grinberg estava na aquisição ou perda dos direitos civis e não na existência da escravidão. O que Rebouças buscava não era o fim da escravisão, mas regular a passagem desta para a liberdade. GRINBERG, K. O Fiador dos Brasileiros. Cidadania, Escravidão e Direito Civil no Tempo de Antônio Pereira Rebouças. Rio de Janeiro: Civilização Brasileira, 2002.

${ }^{402}$ Ver: GRINBERG, K. op.cit.

${ }^{403}$ APUD: MARQUESE, R.B. op.cit. p. 258
} 
o escravo que matasse ou causasse ferimentos leves em seus senhores. Entretanto, após 1853, com a garantia do recurso de graça ao Poder Moderador, muitas condenações à morte foram comutadas em pena de galés perpétuas ${ }^{404}$.

Diferentemente do Brasil, no Sul dos Estados Unidos diversos códigos escravistas estaduais foram instituídos nas primeiras décadas do século XIX para regular o funcionamento da instituição. Esses códigos recuperavam muito do que havia sido legislado no período colonial, atualizando e sistematizando as diversas leis civis e penais a respeito do cativeiro negro. Todavia, cuidavam exclusivamente dos direitos de propriedade dos senhores sobre seus escravos e do controle dos cativos fora de suas plantations, o que conferia aos códigos, na opinião de Marquese, o mesmo sentido da legislação brasileira, interditando somente os excessos. Marquese aponta que o código da Louisiana ${ }^{405}$, apresentado ao poder legislativo daquele estado em 1825, foi bem claro quanto a isso: "o escravo está inteiramente sujeito à vontade de seu senhor, que pode lhe corrigir ou castigar, porém não com vigor incomum, nem tampouco lhe deformar ou mutilar, expondo-o ao risco de perda da vida ou causando sua morte ${ }^{, 406}$ Conforme o autor aponta, tudo isso, contudo, já ocorria de certo modo na ordem legal colonial. Em sua visão, a novidade teria residido na apreensão liberal do caráter da lei escravista no século XIX ${ }^{407}$.

\footnotetext{
${ }^{404}$ A pena de galés consistia em uma espécie de prisão com trabalhos par a o governo na qual o condenado era obrigado a andar com uma calceta presa a suas pernas.

405 Conforme aponta Monica Duarte Dantas, o Código Penal da Louisiana não chegou a ser promulgado. Segundo a autora, ele foi fruto do trabalho do qual o nova-iorquino radicado na Louisiana, Edward Livingston, fora incumbido pelo legislativo daquele Estado em 1821, de revisar suas leis penais. Sua obra, que foi além do Código Penal, foi apresentada ao legislativo em 1825. DANTAS, M.D. "Introdução - Revoltas, motins, revoluções: das Ordenações ao Código criminal", in idem (org.), Revoltas, motins, revoluções: homens livres pobres e libertos no Brasil do século XIX, São Paulo: Alameda Editorial, 2010, p.p.22-33

${ }^{406}$ MARQUESE, R.B. op.cit. p. 259

${ }^{407}$ Importante aqui lembrar a análise de James Gordley sobre o Código Civil Francês. Em Myths of The French Civil Code (GORDLEY, James, Myths of The French Civil Code in: American Journal of Comparative Law, v. XLII, 3, p.p. 459-505, 1994). De acordo com Gordley, o código surgiu da necessidade de harmonizar as leis com a nova ordem revolucionária, enfrentando a dificuldade de encontrar algo como um programa para reformar a lei civil à luz do espírito da revolução. De acordo com Gordley, os princípios do código poderiam sobreviver a revoluções. Foi adotado por Luís XVIII em 1816. Eis que surge a questão: porque o código poderia sobreviver às revoluções? Ao expor algumas das leis sobre propriedade do antigo regime, Gordley mostra que os pagamentos por concessão de terra continuaram, mas deixaram de ser parte da lei feudal e tornaram-se simplesmente aluguéis. Não é a propriedade que muda, mas sim a sua natureza. Ou seja, as leis que regulam as trocas entre entes privados pouco mudaram. O pagamento seria simplesmente isto e não o reconhecimento de um senhorio, conforme especificado no Artigo 530 do Código: uma parte arrenda e a outra tem a obrigação de pagar.
} 
No tocante à experiência brasileira de liberalismo escravista, cabe aqui relembrar a compilação e ordenação das leis sobre escravatura feita por Antonio Joaquim Ribas, em seu manual de Direito Administrativo, em $1861^{408}$. Nele, além dos direitos dos escravos, estão presentes as penalidades previstas na legislação excepcional à qual os mesmos estavam sujeitos ${ }^{409}$, bem como os acordos sobre extradição de cativos celebrados pelo Império.

Cumpre atender-se que a nossa legislação reconhece que a liberdade é de direito natural, e que são mais fortes e de maior consideração as razões que ha á favor dela do que as que podem fazer justo o cativeiro (Lei de $1^{\circ}$ de Abril de 1680); que a favor da liberdade está a presunção pleníssima de direito, e que portanto a prova incumbe aos que contra ela requerem (Lei de 6 de Junho de 1755 § 9o); que a liberdade é de valor inestimável (Alv. de 16 de Janeiro de 1759); e que ás ações e exceções em favor dela são concedidos muitos favores (Peg. 5 for. cap. 107 ; Heineck, VI $\S \S 154$ e 155). De acordo com estes princípios, tem o governo intervindo em alguns casos individuais, afim de proteger a alforria ou livrar os escravos de maus tratamentos da parte de seus senhores. ${ }^{410}$

Vejamos os direitos elencados por Ribas ${ }^{411}$. Segundo o autor, a legislação de então reconhecia certos direitos aos escravos: um escravo podia libertar-se pelo consentimento tácito ou explícito do senhor; o senhor podia reconhecer formalmente, por meio de uma carta de alforria que seu cativo era livre. Por consentimento tácito, Ribas entendia o fato de "expor o infante (Av. de 31 de Janeiro de $1775 \S 7$ ), de abandonar o enfermo (Prov. 1o de 15 de Dezembro de 1823, col. Nab.), de prostituir a escrava, vendida com a condição de o não ser, de receber seu preço, de casar a escrava com homem livre, constituindo-lhe dote, de dar

\footnotetext{
${ }^{408}$ Diferentemente da experiência norte-americana, não houve no Brasil a promulgação de um código negro. Contudo, cabe ressaltar a importância do trabalho de Ribas neste sentido. Para ser aprovada, como foi para o uso nos cursos jurídicos do Império, necessitava de autorização por parte do governo. Sendo assim, o fato de Ribas tê-la obtido, significa que se o governo não concordava com suas opiniões, ao menos não possuía uma grande discordância. Sua obra ganha importância, pois o autor faz um ordenamento da legislação vigente à época a respeito da escravidão.

${ }^{409} \mathrm{O}$ exemplo mais paradigmático desta legislação, que suscitou intensos debates na Seção de Justiça do Conselho de Estado foi a Lei de 10 de junho de 1835.

${ }^{410}$ RIBAS, A.J. Direito Administrativo Brasileiro: Noções Preliminares. (Obra premiada e aprovada pela Resolução Imperial de 9 de fevereiro de 1861 para uso das aulas das Faculdades de Direito de Recife e São Paulo). Rio de Janeiro: F.L. Pinto \& C. Livreiros-Editores 87, 1866, p.p. 364-374.

${ }^{411}$ Apesar das referências a Ribas no tocante aos direitos dos escravos, estes encontram-se também elencados e discutidos de modo mais profundo nos três volumes da obra de Agostinho Marques Perdigão Malheiro, que, diferentemente de Ribas, não somente critica a instituição, como propõe as bases de um projeto para a emancipação dos escravos.. MALHEIRO, P. A Escravidão no Brasil: Ensaio HistóricoJurídico-Social. Petrópolis: Vozes, 1976.
} 
em ato publico ao escravo o nome de filho, de rasgar ou entregar-lhe em presença de cinco testemunhas os títulos da sua escravidão, de constituí-lo herdeiro, etc."412

Outro meio para obter a liberdade era a lei. Porém, não existia lei no Império que obrigasse o senhor a libertar seu cativo. Entretanto, Ribas ressalvava que a jurisprudência brasileira estava admitido que o escravo comum, que obtivesse a liberdade por um dos sócios, poderia obrigar os outros a aceitarem o valor de suas partes, para, com isso, receber a liberdade no todo ${ }^{413}$. Ainda segundo Ribas, esse principio fora confirmado pelo governo na Provisão de 20 de setembro de $1823^{414}$. Ou seja, caso o escravo pertencesse a mais de uma pessoa, poderia, caso um de seus proprietários consentisse, obrigar os outros a aceitarem o pagamento por sua liberdade.

Havia certo privilégio na obtenção de liberdade por parte de escravos pertencentes à fazenda nacional:

Os escravos pertencentes á fazenda nacional têm o direito de receber a alforria: - 1o, dando o seu valor, que deve ser arbitrado por peritos nomeados pela tesouraria; a carta deve ser passada pelo tesouro ou pelo inspetor da tesouraria, por ordem do ministro da fazenda (Ord. de 30 de Outubro de 1847 c n. 358 de 4 de Agosto de 1863); 2o, prestando serviço publico relevante (Av. p. 87 de 26 do Março de 1852, n. 7 de 8 de Janeiro de 1853, 21 de Fevereiro de 1842 e Res. de 11 de Agosto de 1831). ${ }^{415}$

Ribas também afirmava que, de acordo com o art.93, do Decreto ${ }^{\circ} 2.433$ de 15 de junho de 1859 , no caso de o escravo ir à hasta pública como bem de evento, possuía direito de preferência no lance para a sua liberdade a outro qualquer, ainda que superior, sob a condição de cobrir a avaliação ${ }^{416}$. Os escravos, pelo Aviso de 25 de novembro de 1852, poderiam ainda obrigar seus senhores a vendê-los no caso de maus tratos. Além disto, Ribas afirmava que pelo §6 do Art. 14 do Código Criminal, estes castigos eram crimes injustificáveis, incorrendo o senhor nas penalidades da lei comum. Dizia também a esse respeito que, pela lei de 20 de Outubro de 1823 (art. 24 $\S 10)$, os Presidentes de Província em conselho haviam sido incumbidos de promover o bom tratamento dos escravos, além de propor arbítrios para "facilitar a sua lenta emancipação", e, segundo a lei de $1^{\circ}$ de Outubro de 1828 art. 59, fora atribuído ás

\footnotetext{
${ }^{412}$ RIBAS, A.J. op.cit. p.p. 369-370.

${ }^{413}$ RIBAS, A.J. op.cit. p. 370.

${ }^{414}$ RIBAS, A.J. op.cit. p. 370.

${ }^{415}$ RIBAS, A.J. op.cit. p. 370

${ }^{416}$ RIBAS, A.J. op.cit. p.371.
} 
câmaras municipais o direito de vigiar os escravos, informando aos conselhos gerais sobre os maus tratamentos de que fossem vitimas e indicando os meios de prevenção. $^{417}$

Fora isto, Ribas ainda apontava que os escravos, em casos extraordinários, poderiam ser desapropriados pelo governo e libertados, como ocorrera com os cativos que serviram na Farroupilha. Possuíam também o direito de contrair matrimônio com pessoa livre ou escrava e receber qualquer sacramento sem o consentimento de seus senhores. Fazia uma única ressalva no caso dos sacramentos, pois os escravos que se ordenassem padres sem o consentimento dos senhores poderiam ser depostos. Os escravos tinham ainda o direito de comparecer em juízo em nome próprio como autores ou réus com a assistência de um curador, podendo também depor em juízo como informantes, mas não como testemunhas. Quando isto ocorria os senhores eram obrigados a assinar um termo de segurança que, caso fosse infringido, dava ao escravo o direito de requerer judicialmente a sua venda. ${ }^{418}$

Todos estes direitos elencados por Ribas mostram que havia um grande espaço no qual o governo do Estado poderia intervir nos negócios dos senhores de escravos. Entretanto, conforme mostra a documentação da Seção de Justiça do Conselho de Estado, os saquaremas se esforçavam por estabelecer jurisprudencialmente, no cotidiano da administração, os limites desta intervenção sobre o direito senhorial.

\section{2 - O MINISTRO E O TRÁFICO ILEGAL}

Conforme mencionamos no início, discordamos da idéia de silêncio advogada por José Murilo de Carvalho e Ivo Coser. Contudo, não foi nas obras de direito que ele teve de lidar diretamente com a questão, e sim no cotidiano da administração, nas situações objetivas em que tinha de lidar com o tema..

Parron, em sua dissertação de mestrado, aponta que Paulino de Souza nas décadas de 1830 e 1840 (quando ocupou a presidência da Província do Rio de Janeiro e

\footnotetext{
${ }^{417}$ RIBAS, A.J. op.cit. p.p. 371-373.

${ }^{418}$ RIBAS, A.J. op.cit. p.p. $373-374$.
} 
os Ministérios da Justiça e dos Negócios Estrangeiros), não teria se silenciado, como também teria defendido a instituição.

A atuação mais importante de Paulino de Souza como ministro e como parlamentar, no que diz respeito ao tema do presente capítulo, foi sem dúvida na questão do tráfico negreiro intercontinental, que, a despeito do que seu bisneto dá a entender, só ocorreu após muita hesitação. No período compreendido entre 1831 e 1850, existem poucas declarações de Paulino de Souza sobre a questão, salvo em seus Relatórios Ministeriais, que foram objeto de análise de Ivo Coser. Mesmo propondo a tese do silêncio de Uruguai em relação à questão da grande propriedade escrava, Coser procura analisar as idéias de Paulino a respeito do tema em dois momentos, em $1841 \mathrm{e}$ em 1850.

Coser entende que somente nesses períodos o tema esteve presente na reflexão de Paulino. Segundo Coser, o tema da repressão ao tráfico aparecia constantemente em seus Relatórios, quando esteve à frente do Ministério da Justiça, ou seja, entre 1840 a 1843. Em grande parte das vezes, o ministro reclamava da dificuldade em reprimir o tráfico, sob o seguinte argumento: "a sociedade brasileira era contrária à repressão ao tráfico, pois existia na sociedade a convicção de que sem a mão-de-obra escrava a agricultura não poderia sobreviver" ${ }^{\prime 419}$.

Disso, Coser se propõe a analisar como Uruguai avaliava esse modo de ver da sociedade acerca da instituição da escravidão. O autor sugere, como foco de análise, considerar se Uruguai julgava, ou não, esclarecida a opinião existente na sociedade brasileira de que a escravidão era necessária ${ }^{420}$. Para isto, utiliza o conceito de opinião pública, que em sua visão, era o termo utilizado pelos autores contemporâneos de Uruguai para caracterizar as manifestações dotadas de idéias bem esclarecidas, que eram bem diferentes daquelas oriundas das regiões bárbaras do país. Nesse sentido, segundo Coser, Paulino não utilizava o termo opinião pública para designar o pensamento pró-tráfico. Pelo contrário, opinião pública se referia a uma posição

\footnotetext{
${ }^{419}$ COSER, I. op.cit. p. 212.

${ }^{420}$ COSER, I. op.cit. p. 212.
} 
refletida, baseada em um estudo da questão. Sua função seria a de vigiar a ação do Estado, quer de funcionários, quer dos ocupantes de cargos eletivos ${ }^{421}$.

A partir daí, Coser inicia uma discussão sobre o conceito de opinião pública, pois afirma em seu trabalho que Paulino utilizava em seus relatórios o termo “convicção". Entretanto, para entender o papel do Partido Conservador exerceu, é necessário ir além da análise discursiva, olhando para o contexto sócio-político. Diante da Grã-Bretanha, como sugere Parron, políticos brasileiros pró-escravistas apelaram, até 1850 , para a forma oblíqua do discurso indireto livre, confundindo governo com povo, numa estratégia em que "defendem o indefensável e livram-se a si mesmos. Cometem, é verdade, um crime contra o Estado e um erro de conduta moral, mas conhecem bem a sintaxe que empregam." 422 Ou seja, com isto livravam-se da responsabilidade sobre o contrabando, passando-a ao povo. Conforme Parron aponta, mesmo Feijó se valeu da defesa da escravidão em sua campanha para regente.

[...] Ademais, [os brasileiros] julgam os escravos indispensáveis à vida. No Brasil a lavoura está na sua infância: uma foice, uma enxada e um machado é todo o instrumento do lavrador [...] se a terra tem necessidade de alguma cultura, o escravo, obrigado a trabalhos excessivos, [...] em breve tempo perde a vida e empobrece ao senhor: eis o que é mui freqüente entre nós. Ora, neste estado de atraso da nossa agricultura [...] acabar de um jato com o tráfico de pretos africanos é querer um impossível. Ao princípio, pareceu que ao menos a moral ganharia, embora o interesse perdesse; mas, pelo contrário, tudo piorou. ${ }^{423}$

Neste trecho, Feijó abandonou o discurso indireto ("os brasileiros julgam que...") para, "usando o discurso indireto livre, fundir na opinião dos senhores suas próprias convicções. ${ }^{\text {"424 }} \mathrm{Ou}$ seja, afirmar que se tratava do povo preocupado com a ruína da lavoura era um meio de se fazer uma defesa dos interesses escravistas prócontrabando. Aliás, diga-se de passagem, a opinião dos defensores do contrabando nada tinha de irrefletida. Ilmar Rohloff de Mattos considera que os saquaremas construíram o Estado Imperial unindo-se à grande propriedade escravista, notadamente àquela voltada à produção cafeeira da Província do Rio de Janeiro ${ }^{425}$. Seria ingenuidade

\footnotetext{
${ }^{421}$ COSER, I. op.cit. p. 212.

${ }^{422}$ PARRON, T.P. A Política da Escravidão ...op.cit., p.99.

${ }^{423}$ Diogo Antônio Feijó. Diogo Antônio Feijó. Org. e intro. de Jorge Caldeira. São Paulo: Editora 34, 1999, pp. 151-154; APUD: PARRON, T.P. A Política da Escravidão ... op.cit. p.98.

${ }^{424}$ PARRON, T.P. A Política da Escravidão... op.cit. p.98.

${ }^{425}$ MATTOS, I.R. O Tempo Saquarema. São Paulo: Hucitec, 1987, p.p. 282-288.
} 
pensar, como quer Carvalho, que a escravidão era o indizível. Numa importante fala de Uruguai no Senado, em 1858, o período do contrabando é identificado "pública e orgulhosamente" entre 1837 e 1851 - lapso de tempo que os próprios saquaremas entendiam como o de sua maior força na história política do Segundo Reinado.

Em que época, Sr. Presidente, se fundaram esse grandes estabelecimentos de lavour", [...] formados ou reforçados com braços adquiridos desde 1837 até 1851, [isto é, por contrabando] que nestes últimos anos e ainda hoje fazem avultar os produtos de exportação com que pagamos a importação $?^{426}$

Antes de ocupar uma cadeira vitalícia no Senado, Paulino fora Ministro da Justiça, de 1841 a 1843. Por esta época, teve de lidar concretamente com a questão, embora ela ainda não tivesse a mesma importância que viria a ter anos mais tarde.

Em seu Relatório de 1840, como ministro da Justiça, ao tratar do tráfico - em uma pequena parte intitulada "tráfico de africanos", de apenas três curtos parágrafos se limitou a afirmar que o governo não conseguia coibir o tráfico de africanos, porque estava "acoroçoado pelo lucro, pela convicção em que esta é uma parte mui avultada da nossa população, de que a ruína da nossa Agricultura tem de ser inevitável consequiência da cessação desse comércio, e finalmente pela absolvição constante de todos os indivíduos que são acusados de o fazerem "427. Com base nisto, Paulino Soares de Souza destacava que, a despeito da circular de $1^{\circ}$ de março de 1840 , que dava aos Presidentes das Províncias marítimas recomendações para que se empenhassem no cumprimento da Lei de 7 de novembro de 1831, não havia uma efetividade das disposições legais. Por fim, insistia na necessidade do esclarecimento de dúvidas a respeito da execução das Sentenças da Comissão Mista Brasileira e Inglesa. ${ }^{428}$

No ano seguinte, encontramos apenas uma menção lacônica no Relatório do Ministério da Justiça de 1842:

Apesar das mais terminantes recomendações e providências dadas pelo Governo, o tráfico de Africanos tem continuado; posto que em escala muito menor. A convicção muito geral de que a falta de braços Africanos trará a ruína total da nossa Agricultura, e por tanto da nossa riqueza, acarêa muitas simpatias aos importadores e produz a

${ }^{426}$ Anais do Senado, 28 de maio de 1858. APUD: PARRON, T.P. A Política da Escravidão... op.cit. p.133.

${ }_{427}$ Relatório da Repartição dos Negócios da Justiça, 1840, p.41

${ }^{428}$ Relatório da Repartição dos Negócios da Justiça, 1840, p.p.41-42. 
impunidade de que se tem, gozado. O governo não obstante, continua a aplicar todos os seus esforços, como é do seu dever para que seja cumprida a Lei. ${ }^{429}$

Após a saída do gabinete em 1843, Paulino de Souza somente volta a se ocupar publicamente deste assunto ao assumir o Ministério dos Negócios Estrangeiros em 1849, período em que o Império vivia o auge da pressão britânica pela cessação do tráfico negreiro intercontinental. Dada a pasta ministerial que assumiu, Paulino viu-se obrigado a lidar diretamente com o tema. Em seu relatório de 1849, além de dedicar um espaço muito maior a essa questão, é mais direto ao tratar do assunto. Segundo ele, na época da convenção de 1826, pela qual o Brasil se comprometera a acabar com o tráfico, bem como naquelas celebradas posteriormente, teria sido indispensável o emprego de toda a atenção, toda a perseverança, "todos os meios os mais valentes para trazer a um país essencialmente agrícola uma substituição equivalente aos braços, de que aquela convenção o privava". Paulino de Souza afirmava então que as convenções não se ocuparam disto ${ }^{430}$. No mesmo Relatório, Paulino de Souza afirmava que era um erro "combater de frente as necessidades da única indústria que tem o país, sem procurar ao mesmo tempo satisfazê-las, por um modo diverso, mais útil, mais moral, e mais humano, isto é, por meio do trabalho livre" 431

Ou seja, em fins da década de 1840, seu texto já era bastante explícito na valorização do trabalho livre em detrimento do cativeiro. Seu bisneto, José Antonio Soares de Souza, afirma inclusive que coubera a seu bisavô a iniciativa dentro do gabinete no sentido de liquidar com o tráfico. Contudo, na passagem citada fica claro que o trabalho livre "mais moral e mais humano" tinha por objetivo claro o de suprir de braços a lavoura, o que significa, que a questão principal em jogo era a necessidade de mão-de-obra.

Diante do agravamento da pressão britânica contra o tráfico e da pressão interna que havia a favor dele, Paulino foi à Câmara procurar persuadir os deputados a liquidar com o tráfico negreiro a 15 de julho de 1850.

Quando uma nação poderosa como é a Grã-Bretanha, prossegue com incansável tenacidade, pelo espaço de 40 anos, o empenho de acabar com o tráfico com uma

\footnotetext{
${ }^{429}$ Relatório da Repartição dos Negócios da Justiça, 1842, p.p.39-40.

${ }^{430}$ Relatório da Repartição dos Negócios Estrangeiros, 1849, p. 14.

${ }^{431}$ Relatório da Repartição dos Negócios Estrangeiros, 1849, p. 14.
} 
perseverança nunca desmentida ... quando o tráfico está restrito ao Brasil e a Cuba, poderemos nós resistir a essa torrente que nos impele uma vez que estamos colocados neste mundo? (...) A extinção do tráfico há de produzir algum abalo, não já, mas tratemos de ir prevenindo. O que resulta daí é que devemos procurar os meios para contrabalançar esse mal, para aperfeiçoar a nossa produção; porque mais valor tem $\mathbf{1 0 . 0 0 0}$ arrobas de café bem preparado do que 20.000 mal amanhado. Procuremos arredar das nossas cidades esta multidão de escravos que as entulham. ${ }^{432}$

Ao final do discurso, Paulino faz um apelo à Câmara pedindo seu apoio ao gabinete para liquidar de uma vez por todas o problema. A Câmara que, até então se mostrara, antipática a uma medida mais eficaz, após este discurso deu o apoio que o gabinete necessitava, aprovando a chamada Lei Eusébio de Queiroz ${ }^{433}$, em 14 de outubro de 1850 , e exatamente um mês depois o seu regulamento ${ }^{434}$. Após a aprovação destas leis, o governo efetivamente levou a cabo a repressão ao tráfico de africanos. Todavia, até o final do gabinete em 1853, Paulino continuou a ter que se explicar tanto para a Legação Britânica, que ainda não demonstrava confiança no empenho brasileiro, como para seus colegas no Senado. No relatório ministerial de 1851, dizia: “A causa do tráfico está julgada e condenada para sempre" ${ }^{\text {435. }}$

Respondendo às provocações de Holanda Cavalcanti, contrário às medidas adotadas pelo governo, foi à tribuna do Senado justificar sua ação. $\mathrm{O}$ discurso proferido pelo então senador e ministro dos Negócios Estrangeiros a 24 de maio de 1851 expressava suas opiniões a respeito do cativeiro:

Quanto à escravidão está extinta em quase todo o mundo, e especialmente nos Estados da América Meridional que nos cercam e que recusam restituir-nos escravos que para eles fogem com o fundamento de que pisando em seu solo ficam livres; quando a questão da escravidão ameaça romper o grande colosso da União Norte-Americana; quando é impossível resistir à pressão das idéias do século em que vivemos; quando as idéias humanitárias vão em progresso, vivendo nós em um país no qual felizmente cada um pode dizer e escrever o que sente; quando já nesta capital aparecem jornais abolicionistas, conviria que se continuasse a importar todos os anos para o Brasil 50, 60, 100.000 africanos? Não nos aconselhariam todas as considerações de moral, de civilização, da nossa própria segurança e de nossos filhos, que puséssemos um termo à

\footnotetext{
${ }^{432}$ Anais da Câmara dos Deputados. Sessão de 15 de julho de 1850. [Grifo Meu].

433 Decreto $n^{\circ} 708$ de 14 de outubro de 1850, (assinado por Eusébio de Queiroz, Ministro da Justiça) regulando a execução da Lei de 7 de novembro de 1831 que estabelece medidas para a repressão do tráfico de africanos.

${ }^{434}$ Decreto $n^{\circ} 731$ de 14 de novembro de 1850, ((assinado por Euzébio de Queiroz, Ministro da Justiça), regulando a execução da Lei $n^{\circ} 581$ sobre repressão do tráfico de africanos no Império

435 Apud: SOUZA, J. A. Soares de. A vida do Visconde de Uruguai (1807-1866). São Paulo: Companhia Editora Nacional, 1944, p. 219.
} 
importação de africanos, ainda mesmo que a Inglaterra, em virtude de um tratado o não exigisse? $?^{436}$

O ministro deu tamanha importância aos seus discursos anti-tráfico, que, no ano de 1852, tratou de publicá-los sob o título: Três Discursos do Ilmo. e Exmo. Sr. Paulino José Soares de Souza, Ministro dos Negócios Estrangeiros ${ }^{437}$. Ou seja, a monumentalização de seu discurso anti-tráfico começou a ser feita por ele mesmo.

Tratando do discurso de 15 de julho de 1850, aliás reproduzido quase que na íntegra por José Antonio Soares de Souza, Ivo Coser também empreende - assim como outros - uma valorização de certo modo superlativa de seu conteúdo, afirmando que Paulino poderia muito bem centrar sua defesa na pressão inglesa, mas optara também por rejeitar as conseqüências negativas da escravidão. Em sua opinião, o futuro Visconde do Uruguai expunha os argumentos contrários ao tráfico e associava-os à civilização, ou seja, o fim do cativeiro seria necessário ao progresso da civilização. Seguindo o discurso do então ministro, o trabalho livre era qualitativamente superior ao trabalho escravo, havendo assim uma associação, na visão de Coser, entre trabalho livre e civilização.

Coser também afirma que está presente no argumento desenvolvido por Paulino no referido discurso a idéia de que a mão-de-obra escrava era abundante, advindo daí as "vinte mil arrobas" por ela recolhidas. Todavia, isto não resultava em maior qualidade e valor agregados ao produto, quando comparados com o trabalho livre, sendo a escravidão antieconômica, o que reclamava sua substituição ${ }^{438}$.

É preciso, contudo, analisar este discurso com mais cautela, o que implica recolocá-lo na conjuntura em que foi feito. O discurso se centra em questões econômicas, ou seja, que interessavam aos grandes proprietários. Além disso, desde José Bonifácio, havia correntes antiescravistas atuantes na política imperial. No momento em que proferia seu discurso, Paulino tratava de convencer a Câmara a prestar seu apoio ao gabinete. Em um momento tão delicado, deve-se levar em conta

\footnotetext{
${ }^{436}$ Discurso de 24 de maio de 1851 in: Jornal do Comércio, suplemento ao $\mathrm{n}^{\circ} 146$.

${ }^{437}$ SOUZA, P.J.S. Três Discursos de Ilmo. e Exmo. Sr. Paulino José Soares de Souza, Ministro dos Negócios Estrangeiros. Rio de Janeiro: Typographia Imperial e Constitucional de J. Villeneuve e Companhia, 1852.

${ }^{438}$ COSER, I. op.cit. p. 215 .
} 
que era necessário também ao ministério angariar algum apoio no setor antiescravista para garantir a passagem da lei. Necessidade real, dada a identificação de Paulino e seu grupo com o tráfico, fazendo-se imperioso pelo menos não ter a oposição deste setor. Pese-se também que, no corpo do discurso, a parte aqui transcrita (e também citada por Coser e outros) é uma parte pequena. O discurso é permeado pela defesa da soberania nacional, ou seja, de que era melhor que o Brasil acabasse com o tráfico por seus próprios meios do que isto lhe fosse arrancado pela força militar inglesa, contra a qual o Brasil nada podia.

Quanto ao discurso e à iniciativa de 1850, vale retomar o trabalho de Parron, em que discorda da posição defendida por Jeffrey Needell de que o gabinete já subira decidido a liquidar com o tráfico. Parron cita um discurso de Bernardo Pereira de Vasconcelos de 1848, que aponta na direção contrária:

Este governo [o liberal] apresenta-se às câmaras e diz: - Nada de tráfico - : diz muito bem, as leis assim o tem estabelecido, bem ou mal, é direito do país - nada de tráfico. Consome-se o tempo com a discussão de uma lei que já nasceu há onze anos, que não devia entrar em debate; consome-se o tempo com essa lei, fazem-se imensos escarcéus, a imprensa oficial cobriu de impropérios a todos os que tinham repugnância a tal debate, até proclamações apareceram; eu fui um dos que nessas proclamações foram maltratados; e depois de um debate muito comprido, de sessões secretas, entendeu-se que devia ficar adiado indefinidamente este projeto! Ora, em uma medida tão grave, resolver-se o adiamento é coisa incompreensível, senhores. Porém, o mais incompreensível é que ao mesmo tempo que se fecham as portas ao tráfico, se fechem também as portas à colonização. O que se pretende com este sistema $?^{439}$

No ano seguinte, Vasconcelos afirmava não temer a vinda de braços africanos. Para além disso, em 1849, o visconde de Olinda despachou instruções para Londres insistindo na possibilidade de promover o translado de africanos como colonos livres para o Brasil. No início de 1850, quando Paulino de Souza o sucedeu à frente do Ministério dos Negócios Estrangeiros, também procurou saber a respeito da postura da França em relação ao tráfico negreiro para o Império. Fora isto, antes de tomar qualquer medida, o então ministro consultou a Seção dos Negócios Estrangeiros do Conselho de Estado para saber sua opinião. Disto, pode-se ver que o fim do tráfico não estava desde o princípio definido pelo gabinete e que mesmo Paulino Soares de Souza, tido por parte

\footnotetext{
439 Anais do Senado, 27 de setembro de 1848. APUD: PARRON, T.P. A Política da Escravidão... op.cit. p.p. 183-184.
} 
da historiografia como aquele que tomou a iniciativa não estava a priori empenhado no fim do comércio ilegal ${ }^{440}$. Parron aponta ainda que Paulino de Souza, que se declarava completamente empenhado em sustentar o discurso de que o gabinete já subira ao poder decidido a agir, declarou que Olinda tinha preparado algo sobre a supressão do tráfico africano, mas que não o apresentara por não ter encontrado ocasião oportuna, ou porque as dificuldades que enfrentava eram graves, declarando também que ao assumir o gabinete tivera de aprofundar outras graves questões pendentes. ${ }^{441}$

De sua análise, Coser conclui que o silêncio de Uruguai sobre a grande propriedade escravocrata não constituía impeditivo para que na sua reflexão houvesse um modelo de trabalho que o país deveria se organizar para adotar. Segundo Coser, não se tratava da forma de trabalho em voga no país. Em sua visão, "estava presente no argumento de Uruguai, bem como no de Bonifácio, um futuro a ser conquistado, que impõe a adoção de mudanças no aqui e agora da sociedade brasileira" ${ }^{\natural 42}$. Disto, Coser conclui que Uruguai deplorava os efeitos da escravidão. Em sua interpretação, a reflexão de Uruguai, a despeito de não mencionar a grande propriedade escravocrata, incorporava idéias que faziam com que a escravidão se tornasse um empecilho ao desenvolvimento do país ${ }^{443}$. Ora, o discurso de Uruguai no Senado em 1858 que transcrevemos acima mostra justamente o contrário, ou seja, demonstra como ele foi um entusiasta do contrabando.

Como já apontado em diversas passagens, a subida do gabinete de 6 de setembro de 1853 significou o afastamento de Paulino dos gabinetes. Em 1854 foi bastante discutido no Senado o projeto do qual Paulino era signatário, juntamente com o Marquês do Paraná, sobre a ampliação da competência dos auditores da Marinha para processar e julgar os traficantes de escravos e seus cúmplices, mesmo quando a perseguição fosse posterior ao desembarque e longe da costa. O projeto foi aprovado tornando-se a Lei de 5 de junho de 1854, completando, segundo Joaquim Nabuco, a série de medidas legislativas contra o tráfico ${ }^{444}$. Ainda que signatário do projeto,

\footnotetext{
${ }^{440}$ PARRON, T.P. A Política da Escravidão... op.cit. p.184.

${ }^{441}$ PARRON, T.P. A Política da Escravidão... op.cit. p.p.184-185.

${ }^{442}$ COSER, I. op.cit. p. 219.

${ }^{443}$ COSER, I. op.cit. p. 219.

${ }^{444}$ Para uma discussão mais aprofundada desta Lei ver: NABUCO, Joaquim, Um Estadista do Império. São Paulo: Companhia Editora Nacional, 1936, p.p. 165-169.
} 
durante as discussões no Senado, Paulino não tomou parte, o que, a priori, parece servir de fundamento para os estudos que afirmam que ele se retirou da política após sua saída do ministério. Contudo, como poderemos analisar no próximo item, permaneceu plenamente ativo na Seção de Justiça e Negócios Estrangeiros do Conselho de Estado, onde é possível notar com maior clareza a sua atuação pós-ministério e suas idéias a respeito do cativeiro.

\section{3 - O CONSELHEIRO DE ESTADO DIANTE DA ESCRAVIDÃo.}

Conforme já mencionado no Capítulo 2, o Conselho de Estado era o locus do contencioso administrativo do Império. A pesquisa aqui empreendida baseou-se na mais extensa obra publicada com o material da Seção de Justiça do Conselho de Estado que é a coletânea organizada por José Prospero Jeová da Silva Caroatá ${ }^{445}$, Imperiaes Resoluções Tomadas Sobre Consultas da Seção de Justiça do Conelho de Estado, de 1884. Afora a coletânea de Caroatá, também foram utilizadas as consultas referentes aos Negócios Estrangeiros, publicadas em 2005 pela Fundação Alexandre de Gusmão $^{446}$, bem como aquelas que figuram no artigo de José Antonio Soares de Souza a respeito de como Uruguai lidava com os recursos de graça ${ }^{447}$.

Este último aponta para uma lacuna na coletânea de Caroatá, pois Soares de Souza afirma ter encontrado no fundo pessoal de seu bisavô cerca de 57 processos

\footnotetext{
445 Ao lançar olhos sobre a documentação da Seção de Justiça do Conselho de Estado torna-se importante considerar na reflexão alguns apontamentos feitos por Pierre Bourdieu. Segundo Bourdieu, o campo jurídico é o lugar de concorrência pelo monopólio do direito de dizer o direito. Ele se distingue, segundo o autor, por uma cisão social entre profanos e profissionais. A prática teórica e a interpretação de textos jurídicos são diretamente orientadas para fins práticos, constituindo monopólio de intérpretes autorizados. Em sua visão, a concorrência entre os intérpretes está limitada devido ao fato de serem as decisões judiciais diferentes de atos de força políticos somente na medida em que suas decisões e interpretações se apresentam como o resultado de uma interpretação regulada de textos unanimemente reconhecidos, ou seja, Códigos, Constituições e Regulamentos. A sociologia bourdiesiana do direito é coerente com a idéia de direção saquarema defendida por Ilmar Rohloff de Mattos, pois eles forjaram a si mesmos em intérpretes autorizados. BOURDIEU, P. O Poder Simbólico. Rio de Janeiro: Bertrand Brasil, 2007, p.p. 212-214.

${ }^{446}$ BRASIL, Secretaria de Estado dos Negócios Estrangeiros, O Conselho de Estado e a Política Externa do Império: Consultas da Seção dos Negócios Estrangeiros: 1858-1862. Brasília: FUNAG, 2005.

${ }^{447}$ SOUZA, J.A.S. Os Escravos e a Pena de Morte no Império in: Revista do Instituto Histórico e Geográfico Brasileiro, Volume 313, Outubro-Dezembro - 1976. Rio de Janeiro: Departamento de Imprensa Nacional, 1977.
} 
referentes a pedidos e graça, sendo 37 de réus escravos ${ }^{448}$. Encontramos em Caroatá 34 Consultas referentes ao tema da escravidão nas quais Uruguai tomou parte. Destas, 17 tratam de recursos de graça. Sendo assim, há 20 consultas sobre recursos de graça que não foram coletadas por Caroatá. José Reinaldo de Lima Lopes aponta como problema o fato de Caroatá não deixar explícito o critério por ele utilizado para fazer sua seleção e afirma especificamente que os recursos de graça são omitidos em grande número nesta coletânea. Uma hipótese levantada por Lopes é a de que Caroatá tenha levado em conta o maior ou menor grau de complexidade, além do fato de que, como sua coletânea seria mais acessível aos funcionários da justiça do que aos escravos, Caraotá teria enfatizado em sua escolha questões relativas ao funcionalismo ${ }^{449}$.

As consultas a respeito da escravidão das quais trataremos na sequência se dividem em quatro grandes blocos: (a) os já citados recursos de graça em caso de pena de morte; (b) recursos de liberdade; (c) casos de insubordinação; e (d) a questão da extradição dos escravos.

\section{Recursos de Graça em caso de Pena de Morte.}

Ao final da revolta dos Malês em 1835, o parlamento brasileiro aprovou a Lei de 10 de julho de 1835, que vedava qualquer recurso ao Poder Moderador em crimes cometidos por escravos contra seus senhores, determinando em caso de pena capital a execução imediata da sentença ${ }^{450}$. A primeira consulta à Seção de Justiça de que Paulino Soares de Souza participou e de que também foi Relator, de acordo com

\footnotetext{
${ }^{448}$ Idem p.6. Do exame que fez, Soares de Souza apresenta alguns números relevantes. Dos 20 recursos impetrados por réus livres, somente $6(30 \%)$ lograram a comutação da pena, ao passo que dos 37 recursos de réus escravos, 20 (54\%) obtiveram perdão da pena. Apesar de incompleta, a coletânea de Caroatá expressa a tendência de se comutar as penas impostas aos escravos. Dos 17 casos presentes em Caroatá, nos quais Uruguai tomou parte, em $10(58,82 \%)$ a pena foi comutada.

${ }^{449}$ LOPES, J.R.L. Consultas da Seção de Justiça do Conselho de Estado (1842-1889), a Formação da Cultura Jurídica Brasileira. In: Almanack Braziliense nº5 maio/2007. P.21

${ }^{450}$ Antes disto, porém, em 1826 e 1827 foram aprovadas Leis regulando a questão. A Lei de 11 de setembro de 1826 dizia que a sentença de morte proferida em qualquer parte do Império não poderia ser executada, sem que primeiramente subisse à presença do Imperador para poder perdoar, ou moderar a pena, como o art. $101 \S 8^{\circ}$ da Constituição do Império estabelecia. Em15 de setembro de 1827 foi promulgada outra Lei declarando que as sentenças das juntas de justiça que impusessem pena de morte, teriam o recurso de graça.
} 
Caroatá, foi justamente a que originou o decreto ${ }^{451}$ que regularizava os recursos de graça ao Poder Moderador por parte dos escravos que cometessem crimes em que cabia a pena de morte ${ }^{452}$. Paulino foi o relator da consulta, ponderando que "o ponto é: corrigir os erros e injustiças que podem cometer os tribunais, e para atender às circunstâncias, e à equidade, a que os tribunais, sujeitos às regras do direito stricto não podem atender." 453

A discussão naquela ocasião girava em torno do decreto de 9 de março de 1837, que modificara consideravelmente as disposições do de 11 de abril de 1829 , o que seria um elemento favorável à sua derrogação. Assim, o decreto de 9 de março mantinha o dispositivo do Decreto de 11 de abril que vedara o direito de petição de graça ao escravo que matasse seu senhor. Todavia, determinava em seu art. $4^{\circ}$ que, neste caso, não haveria execução sem que fossem participados o governo geral no município da Corte e os Presidentes nas Províncias. Estas autoridades, caso compreendessem que não houvera falha processual, ordenariam a pronta execução da sentença. Contudo, se julgassem conveniente, poderiam dirigir ao Poder Moderador suas observações, para que este tomasse a decisão final. O encaminhamento destas observações suspendia qualquer execução até que fosse tomada uma decisão final. Desta forma, a Seção estabelecia um entendimento de que tal encaminhamento equivalia à petição de graça, com a autoridade ex-offício promovendo e provocando uma decisão do Poder Moderador. ${ }^{454}$

Diante desta questão concluía a Seção:

\footnotetext{
${ }^{451}$ Trata-se do Decreto ${ }^{\circ} 1310$ de 2 de janeiro de 1854 que declara que a Lei de 10 de junho de 1835 deve ser executada sem recurso algum (salvo o do Poder Moderador) no caso de sentença condenatória não só em ocasiões de morte ou ferimentos graves contra o senhor ou o feitor, mas também para as situações de insurreição e quaisquer outros em que caiba a pena de morte.

${ }^{452}$ Resolução de 17 de dezembro de 1853 - Sobre a derrogação dos Decretos de 11 de Abril de 1829 e de 9 de Março de 1837, que vedam o direito de petição de graça, aos escravos que perpetrarem homicídios em seus próprios senhores. Quanto a esta pena, D. Pedro II faz importante anotação em seu diário no dia 2 de janeiro de 1862: "Não sou partidário da pena capital, mas o Estado de nossa sociedade ainda a não dispensa, e ela existe na lei; contudo, usando de uma das atribuições do Poder Moderador, comuto-a sempre que há circunstâncias que o permitam, e, para melhor realização deste pensamento, é sempre ouvida a Seção de Justiça do Conselho de Estado sobre os recursos de graça, consultando ela nesse sentido. A idéia da consulta da Seção para esse fim foi minha." Diário do Imperador Dom Pedro II in: Anuário do Museu Imperial. Petrópolis: Ministério da Educação e Cultura, 1956, p.20.

${ }^{453}$ CAROATÁ, J.P.J.S. op.cit. p. 387. Resolução de 17 de dezembro de 1853.

${ }^{454}$ CAROATÁ, J.P.J.S. op.cit. p.p. 387- 388. Resolução de 17 de dezembro de 1853.
} 
É indispensável que naqueles casos em que a Lei não admite recurso algum ordinário que possa emendar injustiças flagrantes ou violações flagrantes da Lei, se dê sempre o recurso extraordinário ao Poder Moderador, e que não se substitua, ainda que no papel, a faculdade dada aos Presidentes de Província de substituírem-se a este poder. Seria sem dúvida mais simples e claro revogar os 2 Decretos de 11 de abril de 1829 e de 9 de março de 1837, e declarar que das sentenças que impõem pena de morte ao escravo que matar seu senhor há o recurso extraordinário ao Poder Moderador. Uma declaração semelhante, que pareceria nova legislação, tem seus inconvenientes. Uns se acobardariam e se julgariam menos protegidos, outros (os escravos) poderiam atribuir semelhante medida à simpatia pela sua sorte. ${ }^{455}$

Vale ressaltar a importância da última parte do Parecer de Paulino Soares de Souza. Ao mesmo tempo em que defendia que o recurso era uma ferramenta para corrigir eventuais erros no processo e que nem mesmo a um escravo que cometera este tipo de crime deveria ser negado, concluía que deveria prevalecer a segurança daqueles que tinham, em sua visão, algo a perder no caso em questão, ou seja, os senhores de escravos.

As constantes comutações de pena de morte em galés perpétuas não agradavam diversos setores da sociedade. A Assembléia Legislativa da Província de São Paulo enviou à Seção de Justiça uma representação acerca da pena de galés impostas aos escravos, que foi objeto da Consulta de 30 de outubro de 1854. Caetano Maria Lopes Gama foi seu relator, assinando o parecer juntamente com Abrantes e Paulino Soares de Souza. Esta é uma das consultas mais paradigmáticas no sentido de expressar que ao escravo deveriam ser preservadas certas garantias. A Assembléia paulista propunha penas mais severas, pois considerava que as galés não eram eficazes para inibir os crimes cometidos pelos escravos. A Assembléia afirmava que os escravos preferiam as galés ao seu cativeiro, habituando-se, com o tempo, a trazer uma calceta atada aos pés e que "julgam preferível a sorte do galé, e o trabalho forçado nas obras públicas à sua sorte de cativos." $" 456$

A Seção entendeu que a representação paulista se dividia em duas partes: a primeira sobre a sensibilidade física e moral do homem reduzido à escravidão e, a

\footnotetext{
${ }^{455}$ CAROATÁ, J.P.J.S. op.cit. p. 388 [Grifos Meus]. Resolução de 17 de dezembro de 1853. A Seção votou de acordo com o voto do Relator. A Resolução Imperial foi "Como Parece". Em função desta resolução, passou a haver o entendimento de que as sentenças condenatórias à morte subiriam ao Poder Moderador antes de serem executadas.

${ }^{456}$ CAROATÁ, J.P.J.S. op.cit. p. 507. Consulta de 30 de outubro de 1854.
} 
segunda, contestando a eficácia das penalidades aplicadas sobre os escravos. Assim, no entendimento da Seção, a experiência da Lei de 10 de julho de 1835 não tardou a mostrar a sua ineficácia, pois os crimes que ela pretendia evitar, ou diminuir, estavam crescendo, conforme demonstravam as numerosas petições de graça, e os recursos oficiais que subiam ao conhecimento do Poder Moderador. A Conclusão à qual chegava a Seção era de que a Lei de 10 de julho de 1835 não resolvera o problema de adaptar os princípios da justiça à punição de tais crimes. Com base nisto, a Seção afirmava:

Milhares de negros eram anualmente importados ao Brasil, a despeito da lei que proibia este nefando tráfico. Não era possível que eles não viessem a perceber a ilegalidade de sua escravidão. A liberdade concedida aos que dentre eles eram apreendidos no mar ou no desembarque; as revelações de falsos protetores, as sugestões de outros escravos; tudo enfim tem corrido para fazer-lhes conhecer a sua posição, e para que não devêssemos torná-la ainda mais penosa por excessivo e insuportável rigor. Os outros escravos, sendo em grande parte nascidos no Brasil, tem acompanhado o movimento de nossa civilização. Eles sabem que não é a cor, mas somente o acidental estado de seu cativeiro, que os priva de gozar de todos os direitos que a Constituição tão prudente e tão sabiamente concedeu a quem quer que nasce livre no Brasil, de partilhar todos os títulos, honras e cargos a que pode aspirar o cidadão brasileiro, eles vem que até os libertos, seus antigos companheiros de infortúnio gozam de muitos desses direitos. ${ }^{457}$

Mais adiante afirmava a Seção que era contestável quantos dos escravos condenados pela Lei de 10 de junho eram realmente culpados. Segundo parecer, os crimes cometidos contra os senhores haviam aumentado em todos os sentidos, e, caso fossem bem averiguados os dos escravos, se chegaria à conclusão de que uma parte considerável deles teriam senhores por mandantes ${ }^{458}$.

A Seção discordava da afirmação da Assembléia de São Paulo de que a ferocidade era o caráter distintivo dos escravos brasileiros. Na opinião da Seção, caso a Assembléia paulista estivesse correta, “eles que contam entre si muitos indivíduos sabendo ler e que adquirem pela leitura dos jornais amplas noções sobre a liberdade, eles já teriam feito, ao menos, terríveis tentativas de darem ao Brasil o espetáculo do Haiti. $^{, 459}$

Ante o exposto, concluiu a Seção:

\footnotetext{
${ }^{457}$ CAROATÁ, J.P.J.S. op.cit. p. 508. [Grifos Meus]. Consulta de 30 de outubro de 1854.

${ }^{458}$ CAROATÁ, J.P.J.S. op.cit. p. 508. Consulta de 30 de outubro de 1854.

${ }^{459}$ CAROATÁ, J.P.J.S. op.cit. p. 508. Consulta de 30 de outubro de 1854.
} 
Bem diverso, porém é o espetáculo que nossos escravos nos estão dando. Muitos deles se enobrecem no cativeiro pelos exemplos de uma sublime fidelidade para com seus senhores, e estes geralmente os empregam, sem receio no que o serviço doméstico tem de mais íntimo e reservado, resultando daí tão freqüentes concessões de liberdade baseadas em muitas afeições entre senhores e escravos. ${ }^{460}$

Notável este parecer. Ao mesmo tempo em que eram expostos os males sociais da escravidão, a conclusão final é de que o cativeiro enobrecia o escravo. Ou seja, segundo o parecer, o melhor modo de se manter a ordem social escravista era por meio da concessão da liberdade, uma vez que houvesse o consentimento do senhor, e da proteção aos direitos processuais. Uma vez que o escravo tivesse um senhor que não fosse licencioso, e que soubesse mantê-lo dentro dos limites da ordem, ele poderia enobrecer-se. Os limites, contudo, serão evidenciados quando tratarmos das questões de liberdade e insubordinação. Entretanto, isto não impedia que certos direitos fossem defendidos ou concedidos aos escravos. Estes direitos, em sua maioria, referiam-se à forma do processo. Tratava-se de garantir um rito processual no qual o réu tivesse assegurado o seu direito ao contraditório. Mesmo nos casos em que o crime estava provado e, portanto, incluso na Lei de 10 de julho, Paulino Soares de Souza não deixava de defender o direito ao recurso de graça ao Poder Moderador. Neste sentido, é importante levar em conta o que o próprio parecer determinava: uma legislação penal mais rigorosa que a Lei de 10 de julho, que já era uma lei de exceção, estimularia mais revoltas e isto não conviria aos proprietários.

Um caso paradigmático relacionado à Lei de 10 de julho subiu ao Conselho de Estado Pleno. Nas discussões do Pleno podemos ver clivagens entre os conservadores quanto à questão dos direitos dos cativos.

O caso em questão era o processo de responsabilidade contra o Juiz Municipal de Areas, Província de São Paulo, pelo fato de haver mandado executar a sentença de morte a que fora condenado o preto Roque pelo crime de ter assassinado o seu feitor, sem que procedesse a decisão final do Poder Moderador. Por não ter permitido que houvesse recurso de graça, o Juiz Municipal foi suspenso em 6 de dezembro de 1851. Formado processo de responsabilidade contra ele, foi absolvido pelo Juiz de Direito, que entendera haver ignorância do Juiz Municipal sobre a questão. Foram ouvidos o

${ }^{460}$ CAROATÁ, J.P.J.S. op.cit. p. 509. Consulta de 30 de outubro de 1854. 
Juiz de Direito e o Promotor Público a respeito de seus procedimentos.Segundo o Juiz de Direito, "o Juiz Municipal agiu com consciência pura, tendo em vista fazer justiça. Procedera de boa fé." O Promotor Público afirmava que "neste caso a apelação era voluntária, pelo que podia deixar de interpô-la."461

A Seção de Justiça foi consultada em 2 de setembro de 1852, tendo que responder a três perguntas. Primeiramente, se o ato do Juiz Municipal de Areas, pelo qual se formou processo de responsabilidade, deveria ficar impune em virtude da sentença do Juiz de Direito que o absolvera. Em segundo lugar, se o Juiz de Direito deveria ser chamado à responsabilidade por causa da mesma sentença da qual não apelara. E, finalmente, se caberia igual procedimento com o Promotor Público por não ter também apelado. Em parecer assinado por Honório Hermeto Carneiro Leão, Lopes Gama e Limpo de Abreu, a Seção concluiu que, no tocante à primeira questão, tendo apelado no termo legal, da sentença que absolveu o Juiz Municipal, não havia meio para que houvesse prosseguimento no processo de responsabilidade ou a abertura de outro pelo crime de que fora acusado. A Seção afirmava isto tomando por base o princípio de que nenhuma autoridade poderia fazer reviver processos findos. Contudo, a Seção concluía que o Juiz Municipal de Areas deveria ser responsabilizado pela sentença que dera ${ }^{462}$.

A partir deste parecer, a questão subiu ao Conselho de Estado Pleno, sendo discutida em 27 de maio de 1854. O Visconde de Olinda concordou com o parecer da Seção, afirmando que o Promotor Público não deveria ser chamado a juízo, mas que seu procedimento era merecedor de alguma manifestação de reprovação por parte do governo $^{463}$.

Abrantes, Rodrigues Torres, Monte Alegre, Miranda Ribeiro, Lopes Gama, Lima e Silva e Araújo Viana votaram pela conclusão do parecer sem observação alguma. Holanda Cavalcanti votou com o parecer, mas adotou as observações de Olinda. Montezuma votou com o parecer, mas destacou que as observações de Olinda não lhe faziam peso. Paulino de Souza afirmava concordar com o parecer, mas fez observações:

\footnotetext{
${ }^{461}$ CAROATÁ, J.P.J.S. op.cit. p.525. Resolução de 10 de dezembro de 1854.

${ }^{462}$ CAROATÁ, J.P.J.S. op.cit. p. 526. Resolução de 10 de dezembro de 1854.

${ }^{463}$ CAROATÁ, J.P.J.S. op.cit. p. 527. Resolução de 10 de dezembro de 1854.
} 
Que o Juiz de Direito era culpado não somente por haver indevidamente absolvido o Juiz Municipal, como por não haver cumprido o Artigo $3^{\circ}$ do Decreto de 9 de março de 1837, que lhe incumbia remeter ao Poder Moderador cópia da sentença acompanhada de um relatório: Que em lugar de se proceder assim, foi a sentença remetida ao Juiz Municipal, que é o executor; circunstância que podia induzir a crer que não havia mais nada que fazer, senão executar a sentença: Que se o Juiz de Direito tivesse cumprido aquela Lei, a sentença não teria sido executada sem a decisão do Poder Moderador, porque então penderia esse recurso, o que deveria constar dos autos no Cartório do Escrivão, e na Secretaria da Presidência da Província, por cujo intermédio são aqueles recursos de graça remetidos. Disse mais o mesmo Conselheiro que não lhe pareciam procedentes as observações do Conselheiro Visconde de Olinda, visto que a conclusão do Parecer da Sessão, sobre a qual recaia a votação não se referia especialmente a artigo algum do Código Penal, mas era muito lata, dizendo assim = É pois a Seção de parecer que o Juiz de Direito deve ser responsabilizado pela sentença que deu = Fica portanto salva a quem promover a responsabilidade a faculdade de compreender o fato nos artigos do Código que lhe corresponderem. ${ }^{464}$

Esta intervenção de Paulino de Souza é bastante reveladora, pois ao passo que Olinda já procurava em qual artigo da Lei Penal poderia ser enquadrado o Juiz de Direito, Paulino não queria envolver o governo na questão, deixando isto a cargo do julgador.

José Antonio Soares de Souza, entretanto, traz à luz uma importante discussão privada entre Eusébio de Queiroz e o visconde do Uruguai a respeito da sentença do réu escravo Agostinho, condenado à morte pelo júri de Vila Jacobina. Na correspondência entre os dois, Uruguai posicionava-se favoravelmente à condenação (ainda que na carta apenas mencione o parecer que enviara a Eusébio, mas sem expor seus argumentos). Eusébio, porém, não era favorável à aplicação da pena última. Uruguai, argumentando que não desejava discordar do amigo, mudou o seu parecer ${ }^{465}$. Infelizmente, este recurso de graça não aparece na coletânea de Caroatá $^{466}$.

\footnotetext{
${ }^{464}$ CAROATÁ, J.P.J.S. op.cit. p. 527. Resolução de 10 de dezembro de 1854.

${ }^{465}$ SOUZA, J.A.S. op.cit. p.15. Vale dizer que o caso deste escravo não figura na coletânea de Caroatá

${ }^{466}$ Paulino Soares de Souza, já Visconde do Uruguai, iria discordar de Olinda quanto a outro parecer do qual fora também relator na Seção de Justiça, em 1855. A consulta dizia respeito à dúvida de se a Lei de 10 de Julho de 1835 estaria implicitamente revogada pela Lei de 2 de Julho de 1850, quanto aos crimes cometidos por escravos nas fronteiras, e se, conseqüentemente, competia (ou não) ao Juiz de Direito o julgamento desses crimes. Além disto, deveria-se responder também se, competindo aos Juízes de Direito, subsistia a disposição da dita Lei que negava aos escravos condenados qualquer recurso. Uruguai dizia que "Executar uma sentença de morte em um homem, porque enfim o escravo é homem, por uma sentença proferida em processo verbal e sumaríssimo, por Juiz singular, sem recurso algum é ato repugnante, indigno de aparecer entre as Leis de uma nação cristã e civilizada." Este parecer foi apreciado pelo Conselho de Estado Pleno, onde houve oposição principalmente por parte de Olinda e Jequitinhonha. Olinda centrou-se no aspecto jurídico do parecer, afirmando que não lhe parecia tão clara
} 
Recursos de Liberdade

Além dos recursos de graça, a Seção também arbitrou questões de liberdade, embora isso não fosse tão comum quanto os recursos de graça, uma vez que o tema era tratado nos tribunais ordinários. Contudo, vale a pena discuti-los, pois mostram os limites da defesa de direitos dos escravos que se lê na resposta dada à Assembléia paulista em 1854.

Este foi o caso da Resolução de 18 de março de 1854: "Sobre a dúvida proposta pelo $3^{\circ}$ suplente do Juiz Municipal de Macapá: se é lícito ao Juiz de Partilhas aceitar o preço da avaliação para conferir a liberdade a um casal de escravos do casal inventariado". O casal de escravos requeria a sua liberdade mediante pagamento, porém, havia a oposição unânime de todos os herdeiros. O parecer do Presidente da Província e do Juiz de Direito evocava o Art. 179, § 22 da Constituição, em que eram definidos os direitos de propriedade, para afirmar que não era lícito neste caso a compra da alforria. Paulino Soares de Souza foi o relator do parecer da Seção de Justiça, afirmando que:

Ninguém pode ser obrigado a forrar um escravo, porque não há Lei que a isso obrigue. Isto é duro, sem dúvida, mas é uma conseqüência da escravidão. Razões de Estado o exigem, para que essa escravidão não se torne mais perigosa do que é. (...) É muito duro sem dúvida, por exemplo, recusar o preço de avaliação ao escravo que serviu por longos anos com fidelidade o falecido senhor, que o acompanhou até seus últimos momentos porque a avidez dos herdeiros a isso se opõe. Um privilégio assim, dado a longos serviços, à fidelidade e a um bom procedimento poderia ser útil. Mas não há Lei que o estabeleça para este e outros casos semelhantes, e somente por Lei pode ser estabelecido. $E$ por Lei que previna os abusos. ${ }^{467}$

a revogação. Em sua opinião, somente os Códigos possuíam a força de revogar leis sem lhes fazer expressa menção. Neste caso, em sua opinião, tratava-se de uma lei solta e que, portanto, não poderia ser interpretada deste modo. Jequitinhonha contestou a humanidade dos escravos que Uruguai alegara no parecer. CAROATÁ, J.P.J.S. op.cit. p.p.559-560. Resolução de 17 de março de 1855. Na Resolução de 10 de abril de 1854 - "Sobre o ofício do Presidente da Província do Pará pedindo solução às dúvidas do Juiz de Direito da Comarca de Cametá a respeito da execução da sentença proferida contra o réu escravo João Rafael, que assassinara a José Mariano Vulcão, irmão e administrador da fazenda de seu senhor João Florêncio Vulcão" -, a Seção, em parecer do qual Uruguai também foi o relator, comutou a pena para prisão com trabalho na Casa de Correição da Corte e responsabilizou o Juiz de Direito por erros no processo. CAROATÁ, J.P.J.S. op.cit. p.p. 433-435. Resolução de 10 de abril de 1854

467 CAROATÁ, J.P.J.S. op.cit. p. 426. [Grifos Meus] Resolução de 17 de dezembro de 1853. 
A idéia contida neste parecer nos remete ao pensamento de Antonio Pereira Rebouças, cuja luta era justamente para regular a passagem do cativeiro à liberdade por meio da Lei. Há, porém, uma diferença fundamental. Apesar de dar um parecer com este teor, Paulino sequer chegou a cogitar projeto semelhante ao de Rebouças. Diante de uma questão de liberdade, a despeito de censurar a avidez dos herdeiros, Paulino de Souza votou pela não liberdade do escravo. Somente o senhor poderia obrar este ato de generosidade. O livro de Antonio Joaquim Ribas, do qual tratamos anteriormente, mostra os espaços do governo da casa, ou seja, do poder privado, que podiam ser invadidos pelo governo do Estado. Este parecer, sem dúvida, mostra jurisprudencialmente, pela posição de um dos mais importantes órgãos políticoadministrativos do Império, o limite até onde a invasão da casa era possível.

Na coletânea de Caroatá constam mais casos de liberdade. No caso da resolução de 28 de dezembro de 1859 - "Sobre o requerimento de Thomaz, filho de uma africana livre, cujos serviços foram dados à Fábrica de Pólvora, pedindo ser desligado do serviço daquele estabelecimento, visto ter nascido no Brasil e ser maior de 21 anos" -, o pedido é deferido pela Seção. Diante de pareceres favoráveis do Diretor da Fábrica e do Conselheiro-Procurador da Coroa, no qual ressaltam o bom comportamento de Thomaz e o apontamento da própria Fábrica que atesta sua idade, a Seção limita-se a afirmar que "entende que em verdade não pode deixar de atender ao bom direito que assiste. ${ }^{\text {468 }}$ Mas vale ressaltar, que, neste caso, o próprio senhor consentia na liberdade. O governo do Estado nada mais fez, portanto, do que referendar sua vontade.

Outro caso também relevante de liberdade aparece na Resolução de 5 de junho de 1863 - "Sobre o Ofício do Presidente da Província de Pernambuco e mais papéis que o acompanharam relativamente ao pardo Simplício que se tratava de reduzir a escravidão". O Relator deste Parecer foi Euzébio de Queiroz. O Visconde do Uruguai e José Antonio Pimenta Bueno assinavam o parecer junto com o Relator, sem apresentar voto separado. Simplício havia sido libertado por Antonio Gonçalves, de quem sua mãe Luiza era escrava, no momento de seu batismo. Em maio de 1859, Simplício obteve do Juiz Municipal de Barreiros um mandado de manutenção de sua liberdade. Todavia, em maio de 1861, o Delegado de Água Preta pretendia cativá-lo como escravo fugido do

${ }^{468}$ CAROATÁ, J.P.J.S. op.cit. p. 844. Resolução de 28 de dezembro de 1859 
Tenente-Coronel José Luiz da Costa Lins. O pretendido senhor alegava que antes da alegada libertação Simplício e a mãe já haviam sido a ele vendidos e que, portanto, a liberdade de Simplício não era válida. Contudo, o Juiz Municipal de Barreiros, alegava que Simplício apresentara em juízo testemunhas de sua liberdade, e por isso obtivera o mencionado mandado. O Tenente-Coronel Caldas Lins opôs-se à decisão recorrendo do mandado, alegando que Simplício obrava por manipulação de seus inimigos. Todas as sentenças que se seguiram a esta foram em favor de Simplício. Ao chegar à Seção de Justiça, esta se limitou a dizer que uma questão de liberdade era da alçada do Poder Judiciário, o único competente para resolvê-la, "tanto mais quanto a sentença proferida foi no todo contrária não ao acerto do escravo, e sim ao que pretende o senhorio, o qual é pessoa habilitada para fazer valer seus direitos perante os tribunais."

Diante de um caso julgado pelos tribunais, a Seção não fez, portanto, grandes considerações. Contudo, quando se tratava de defender os direitos dos herdeiros proprietários, como foi o caso da Resolução de 18 de março de 1854, manifestou-se em defesa deste direito. No caso de Simplício, a despeito das sentenças que o favoreciam, tendo como agravante o fato de Caldas Lins não possuir prova maior do que a própria palavra, a Seção não fez menção ao direito à liberdade que cabia à Simplício. Preferiu afirmar não ser o juízo competente. Novamente está aqui manifesto o limite até onde era lícito intervir na esfera privada de poder.

Fica assim claro que quem podia decidir algo sobre a sorte do escravo era o senhor. Quando se tratava de uma ação de liberdade, a decisão cabia ao proprietário, ou como no caso que vimos acima, a Seção se recusava a tomar partido do cativo ${ }^{470}$.

\footnotetext{
${ }^{469}$ CAROATÁ, J.P.J.S. op.cit. p. 1031. Resolução de 5 de junho de 1863.

${ }^{470}$ Para uma maior discussão dos casos de liberdade ver: LIMA, R.P. A Nefanda Pirataria de Carne Humana.: Escravizações Ilegais e Relações Políticas na Fronteira do Brasil Meridional (1851-1868). Porto Alegre, Dissertação de Mestrado apresentada ao Programa de Pós-Graduação em História da Universidade Federal do Rio Grande do Sul, 2010. NEQUETE, L. O Escravo na Jurisprudência Brasileira: Magistratura e Ideologia no Segundo Reinado. Porto Alegre: Tribunal de Justiça do Rio Grande do Sul, 1988,
} 


\section{Insubordinação}

A insubordinação de escravos era uma questão muito presente para a Seção de Justiça. As discussões em torno dos recursos de graça em caso de pena de morte remetem a isto, pois e Lei de 10 de julho foi criada justamente para conter a insubordinação. A Resolução de 6 de julho de 1854 - “Acerca do ofício do Presidente da Província do Pará cobrindo o do Chefe de Polícia relativo ao estado de insubordinação dos escravos das fazendas da Ordem do Carmo da mesma Província" -, da qual Paulino foi relator, é paradigmática. No seu ofício o Presidente afirmara que os escravos da província se encontravam em "insubordinação acoroçoada pelos repetidos exemplos de imoralidade, má administração e procedimento licencioso do atual prior", sendo isso atestado por diversos atentados e crimes cometidos por escravos que invadiam as propriedades vizinhas, tendo "roubado, ameaçado e espancado os habitantes do Rio Bujurú."

Ante o ofício, afirmava a Seção:

Em um país onde existe a escravidão, nada há que seja tão perigoso e funesto do que o exemplo de porções de escravos sem governo, insubordinados e desmoralizados.

A Seção crê que são necessárias providências enérgicas e que cortem logo o mal pela raiz, passando aqueles escravos para o poder de pessoas que os vigiem, corrijam, contenham, e os façam trabalhar. Qualquer senhor o fará, porque esse é o seu interesse. ${ }^{472}$

Disto, a Seção concluiu que a solução seria ordenar a apreensão e venda em hasta pública, pelo Juiz de Capelas, de todos os escravos que fossem propriedade da Ordem do Carmo na Província do Pará, mantendo-se somente os que fossem indispensáveis ao serviço do convento. Por fim, a Seção afirmava que seria conveniente a extensão desta medida a todas as fazendas e escravos das ordens religiosas. ${ }^{473}$

Vemos neste parecer como Paulino Soares de Souza tinha repulsa à insubordinação dos escravos. Mas, novamente, cumpria primeiramente ao proprietário exercer a sua jurisdição. O culpado deste estado de coisas era o prior da Ordem do Carmo que não sabia manter os escravos dentro dos seus limites, daí pedir que os

${ }^{471}$ CAROATÁ, J.P.J.S. op.cit. p.476. Resolução de 6 de julho de 1854.

${ }^{472}$ CAROATÁ, J.P.J.S. op.cit. p.476. Resolução de 6 de julho de 1854.

${ }^{473}$ CAROATÁ, J.P.J.S. op.cit. p.476. Resolução de 6 de julho de 1854. 
escravos insubordinados fossem passados ao poder de pessoas que os vigiassem e fizessem trabalhar. Ainda no parecer, Paulino sugere a venda dos escravos insubordinados em hasta pública. Ao alegar que as medidas adotadas em relação aos escravos da fazenda da Ordem do Carmo deveria ser estendida às demais ordens religiosas, apresentava motivos que retratavam sua visão sobre a questão: o fato de elas administrarem mal seus estabelecimentos, sendo impróprias para a conservação da disciplina e subordinação da escravatura; a improdutividade dos estabelecimentos nas mãos das ordens religiosas; a ausência de mão-de-obra no país, tornava conveniente qualquer medida que objetivasse tirar o maior proveito da força de trabalho disponível. Conclui afirmando que o governo não poderia tomar uma medida semelhante em relação às demais ordens religiosas sem a autorização do Poder Legislativo ${ }^{474}$.

Apesar das ponderações que faz, o parecer não deixa de mostrar um caso em que, na visão de Uruguai, era lícita a invasão da esfera de poder do proprietário. As três razões apontadas mostram com que objetivo o governo deveria intervir: manter a disciplina da escravatura, tornar produtivos estabelecimentos improdutivos e, finalmente, aproveitar melhor os braços ociosos, principalmente quando, findo o tráfico, estes começaram a se tornar mais escassos.

\section{Extradição de Escravos e Contratos de Trabalho}

Outra questão à qual foi chamada a Seção a responder foi a respeito dos contratos de trabalho firmados entre fazendeiros brasileiros e seus escravos que ao entrarem no território uruguaio tornavam-se livres. Em ofício datado de 25 de maio de 1852, o representante brasileiro no Estado Oriental afirmava que o governo daquele país garantiria o cumprimento de contratos celebrados entre os senhores e os escravos que ali entravam como libertos, tornando-se devedores do valor de sua liberdade. Em nota ao representante brasileiro, datada de 30 de agosto do mesmo ano, o Ministro das Relações Exteriores da República Oriental afirmava que supunha que os proprietários de escravos introduzidos do Brasil, ao território vizinho, tivessem celebrado com eles algum contrato prévio equivalente ao valor de seus serviços.

${ }^{474}$ CAROATÁ, J.P.J.S. op.cit. p.476. Resolução de 6 de julho de 1854. 
Quanto a isto ponderava a Seção:

A república pode, é verdade, declarar que não admite mais esses contratos para o futuro, pode mesmo, e quando muito, determinar que se retirem do seu território esses homens, cuja liberdade depende de condições; além, não vai o seu direito. (..) A Lei que, de surpresa, os declarasse nulos e, por consequiência, livres os escravos, independentes de preencherem a condição de serviços com que lhes fora concedida a liberdade, seria um atentado, uma fraude imprópria de governos civilizados. ${ }^{475}$

Estava tramitando no Senado Oriental um projeto de não reconhecimento destes contratos, o que gerou a oposição dos conselheiros. Em parecer do qual Eusébio de Queiroz foi relator e Uruguai e Maranguape foram signatários a Seção afirmava:

Nossas leis e prática autorizam a concessão da liberdade, pelo preço da avaliação, aos senhores que manifestam a intenção de libertar. (...) Conviria, igualmente, manifestar o firme propósito de reconhecer e manter a liberdade dos que nasceram no Estado Oriental e que se diz terem sido enviados ao Brasil como escravos. (...) Em todo o caso, porém, entende a Seção que, paralelamente e sem perda de tempo, convém que o Governo Imperial faça constar que não terão a proteção do governo quaisquer reclamações que se façam por no futuro, nem tampouco os anteriores, que não acudirem ao reclamo acima aconselhado. Conviria, igualmente, que, desde já, se empregassem as diligências para restituir à liberdade os que nascerem no Estado Oriental, desses libertos ali introduzidos unicamente como onerados à prestação de serviços temporários; porque, decerto, esses são livres. ${ }^{476}$

Aqui há a defesa de outro direito, o dos contratos. Fazia-se imperioso garantir a execução dos contratos, inclusive no tocante à liberdade dos escravos, assegurando-a àqueles que a tivessem obtido por meio de contratos com seus senhores. Cumpre, no entanto, fazer algumas ponderações. O interesse do Rio de Janeiro no cumprimento destes contratos de trabalho servia justamente para desestimular fugas ao Estado vizinho. Uma vez libertados, era necessário assim mantê-los, pois, caso contrário, as consequiências poderiam ser piores aos senhores. Caso a República Oriental do Uruguai não reconhecesse mais os ditos contratos, o escravo brasileiro poderia para lá se dirigir, tornar-se livre e não ter que cumprir qualquer obrigação para com o seu antigo senhor. Algo assim não poderia ser admitido pelos proprietários ${ }^{477}$.

\footnotetext{
${ }^{475}$ BRASIL, O Conselho de Estado... p.310. Parecer de 8 de julho de 1861

${ }^{476}$ BRASIL, O Conselho de Estado... p.310. [Grifos Meus]. Parecer de 8 de julho de 1861

${ }^{477}$ Ver: GRINBERG, K. Escravidão e Liberdade na fronteira entre o Império do Brasil e a República do Uruguai: notas de pesquisa. Cadernos do CHDD (FUNAG), v. 5, p.p. 91-114, 2007. Ver também o já citado trabalho de Rafael Lima: LIMA, R.P. A Nefanda Pirataria ... op.cit. p.p. 44-78.
} 
O fato de não haver escravidão no Estado vizinho estimulava fugas, daí a preocupação expressa no parágrafo anterior. A extradição de escravos refugiados na República Oriental foi também tema de consulta à Seção dos Negócios Estrangeiros, sendo o Visconde do Uruguai o seu relator em 22 de junho de 1863. A Seção fora provocada a partir de representação dirigida ao Imperador pela Assembléia de São Pedro do Rio Grande do Sul. A dita Assembléia reclamava que a extradição de escravos era regulada por tratados, cuja interpretação, a seu ver, não podia ser outra senão "os escravos segundo as leis do Brasil". Devido ao fato de não haver escravidão no país vizinho, não seria possível estabelecer ali títulos sobre ela. No cerne de sua reclamação estava a reivindicação de que a República Oriental reconhecesse a propriedade escrava, conforme as leis brasileiras. Uruguai, em seu parecer, afirmava que não se poderia dizer que houvesse uma violação de tratado, sendo que para obrigar o Estado Oriental a devolver um indivíduo reclamado, em razão deste tratado ${ }^{478}$, eram indispensáveis três condições: a primeira é que o indivíduo reclamado fosse escravo; a segunda é ele fosse propriedade do reclamante; e, a terceira é que sua permanência no território oriental fosse contra a vontade de seu senhor. Para o autor do parecer, o que era vedado à República Oriental era negar a propriedade e modificar as condições de sua natureza, possuindo ela o direito de exigir provas da identidade e de ser convencida. Reafirmando que não houvera violação de tratado, o parecer trazia as seguintes observações:

O escravo não tem estado civil. Quase que sempre tem um nome, o de Batismo. Não tem apelidos de família. O escravo não tem família. Chama-se Joaquim, Manoel, João e confunde-se com todos os da mesma cor e do mesmo nome (...) Demais, os escravos africanos não tem certidões de idade. Da maior parte, principalmente dos que foram introduzidos depois da extinção do tráfico, não há títulos de venda. (...) Era indispensável não consagrar, em documentos, provas da importação ilícita. (...) Este assunto, como humanitário, é de grande melindre e odiosidade. O governo de Vossa

Majestade Imperial já tem apalpado os espinhos de que se acha ele eriçado, quando o tem tratado com a Guiana Francesa, com as repúblicas do Peru e Venezuela, e outros conterrâneos que nos cercam e aboliram a escravidão. E tem de haver-se com senhores de escravos, que não admitem dúvidas e indagações e

\footnotetext{
${ }^{478}$ Refere-se aos tratados de outubro de 1851, celebrados por Paulino Soares de Souza com o Estado Oriental, nos quais, entre outras coisas, regulava-se a extradição de escravos.
} 
querem haver logo a sua propriedade, sem se porem em regra e sem o menor incômodo. $^{479}$

$\mathrm{Na}$ parte final do parecer figura o duplo problema que estava por trás das extradições, isto é, o fato de o Império ter que reclamar a posse perante outro país, o que gerava não raro problemas diplomáticos, e principalmente o de ter de se haver com os proprietários dos escravos reclamando sua posse. Uruguai, bem como outros políticos ligados ao Partido Conservador, tinha como pilar a grande propriedade escrava. Não lhe interessava entrar em conflito com ela. Daí o grande esforço empreendido também na esfera externa mediante tratados de extradição que garantissem a devolução do escravo reclamado ao seu senhor.

Do exposto no presente capítulo, podemos afirmar que Uruguai não silenciou a respeito da escravidão. Pelo contrário, percebemos que ela ocupava muito de sua atenção. É fato que, em muitas ocasiões, não a mencionou, como se nota da redação de seus livros. Ademais, mesmo se, em diversos momentos, seu discurso parece aproximálo do liberalismo escravista de Antônio Pereira Rebouças, uma leitura atenta da documentação mostra que eram na verdade bastante díspares as opiniões dos dois. Sobretudo, não é possível afirmar que Uruguai refutasse a instituição do cativeiro.

Se tanto Rebouças quanto Uruguai reconheciam a legitimidade da instituição, cabe apontar que Uruguai estava mais preocupado em evitar revoltas e preservar a ordem sem que o governo invadisse o âmbito do direito privado dos senhores. Baluarte do Regresso, entusiasta do contrabando ilegal, deixou claro o descontentamento com a ausência de uma legislação específica sobre a instituição, mas nunca defendeu que se regulasse a compra da alforria. Não podemos, portanto, afirmar que partilhavam das mesmas idéias.

Uruguai deixou clara a repulsa que tinha em relação à insubordinação dos cativos, ou seja, os limites de seu liberalismo. Vimos no caso dos escravos da Ordem

479 O Conselho de Estado e a Política Externa do Império, Consultas da Seção dos Negócios Estrangeiros (1863-1867). Rio de Janeiro: Fundação Alexandre de Gusmão, 2005, p.p. 41-42. [Grifos Meus]. Parecer de 22 de junho de 1863. 
do Carmo no Pará, que Paulino chegou mesmo a cobrar que o Poder Legislativo armasse o governo de meios para conter a insubordinação dos escravos das ordens religiosas.

Ainda assim, sua defesa dos direitos processuais dos escravos e, quando possível, da comutação da pena de morte em galés o diferenciava de alguns de seus companheiros de partido ou mesmo de ministério, como ficou evidente nas suas divergências com Jequitinhonha e Olinda. Sua discordância com Euzébio de Queiroz mostra como nem mesmo na chamada trindade saquarema havia consenso quanto à questão, embora tenham agido de modo razoavelmente coeso quando da defesa do contrabando.

Importante para a reflexão a respeito dos recursos de graça é a observação de José Reinaldo de Lima Lopes de que a própria idéia de graça implicava a falta de uma regra geral, sendo cada caso examinado por seus fatos particulares ${ }^{480}$. Diante do aumento dos crimes praticados por escravos, a despeito da Lei de 10 de julho, a própria Seção admitia que não seria um maior rigor da Lei que acabaria com o problema, ou seja, ficava explícita a sua propensão a minorar penas a partir da análise de erros no processo.

Vimos ao longo do capítulo também a mitificação em torno do discurso de 15 de julho de 1850 na Câmara, que, diga-se de passagem, o próprio Paulino de Souza iniciou quando publicou o discurso em 1852. Uruguai é exemplo de uma das múltiplas variações do liberalismo escravista. Membro do Partido Conservador, teve papel proeminente em aliar os líderes de seu Partido à grande propriedade escravocrata, em especial aos cafeicultores fluminenses.

A defesa do interesse dos proprietários se projetava inclusive para o plano externo, como se pode perceber nas questões envolvendo extradição de escravos. Paulino, quando no Ministério dos Negócios Estrangeiros buscou solucionar este problema por meio de tratados internacionais que regulassem a extradição. Todavia, estes acordos não impediam que houvesse problemas diplomáticos quando se reclamava a posse de um cativo que passara a território estrangeiro. Era de interesse

\footnotetext{
${ }^{480}$ LOPES, J.R.L. Consultas da Seção de Justiça do Conselho de Estado (1842-1889), a Formação da Cultura Jurídica Brasileira. In: Almanack Braziliense no 5 maio/2007, p. 21.
} 
dos senhores de escravos que isto fosse regulado. Neste contexto, também interessava o cumprimento dos contratos celebrados entre senhores e escravos, que garantiam a liberdade destes últimos ao trabalharem em território estrangeiro. Seu cumprimento não estimulava novas fugas.

O Visconde do Uruguai não ignorou o cativeiro. Comutou condenações à morte, reconheceu os escravos como homens, procurou garantir que tivessem as mesmas garantias processuais que um homem livre. Isto não o impediu de defender o contrabando e de repudiar a insubordinação dos cativos, reclamando medidas para contê-los. Assim como muitos homens de seu tempo, era um liberal (não no sentido partidário do termo) escravista. 


\section{CONSIDERAÇÕES FINAIS}

A pesquisa aqui desenvolvida mostra que o Visconde do Uruguai, conforme aventado na Introdução, não se retirou da política depois que saiu dos ministérios. Importante frisar que não podemos deixar de considerar que a própria escrita de suas obras foi uma forma bastante eficaz de atuação política. Sua presença no Conselho de Estado e no Senado fez parte de uma opção por uma determinada modalidade de atuação, apesar da afirmação recorrente de que havia se afastado da política. Conforme já mencionado na Introdução, Uruguai, nos Estudos Práticos, afirma que "é o Conselho de Estado quem, na obscuridade, tem trabalhado mais para montar o país e firmar as boas doutrinas, sem que daí infelizmente tenham sido colhidos notáveis resultados" ${ }^{481}$. Ora, isso deixa muito claro que sua opção foi a de se dedicar a uma tarefa a seu ver mais nobre (ou importante), ou seja, construir o país em nome do bem público que deveria estar acima das paixões políticas.

Apesar de não mais voltar a ocupar pasta ministerial alguma e de recusar por duas vezes a Presidência do Conselho de Ministros, o Visconde manteve-se fiel ao Partido Conservador. Isso inevitavelmente levanta a questão dos motivos que o levaram a recusar a chefia do gabinete. Quando ascendeu o ministério da Conciliação, em 1853, Uruguai, juntamente com Euzébio de Queiroz e Rodrigues Torres, passou a integrar a ala dos "emperrados" do Partido Conservador. No Capítulo 1, vimos como a crescente interferência do Imperador nos negócios dos gabinetes desagradara a chamada trindade saquarema, ao ponto de o ministério de 29 de setembro de 1848 ter pedido exoneração coletiva em 1851. Ao longo do referido Capítulo, mostramos que, mesmo no Ensaio, Uruguai defendia uma divisão clara entre o Poder Moderador, privativo do monarca, e o Poder Executivo, chefiado pelo Imperador, mas exercido pelos ministros. Na Conciliação, predominou o pensamento das Idéias Gerais, que consagrava a preeminência de Pedro II sobre os gabinetes. Defensor do Poder Executivo sem intervenção direta do monarca na política ministerial, Uruguai provavelmente não iria

\footnotetext{
${ }^{481}$ URUGUAI, V., Estudos Práticos Sobre a Administração de Províncias do Brasil, Rio de Janeiro: Typografia Nacional, 1865, p.p. XLVI-XLVII
} 
querer ser um Presidente do Conselho de Ministros sem a liberdade de aplicar a política de seu partido.

Quanto ao desafio proposto no início desta tarefa - o de elucidar um projeto de organização do Estado Nacional defendido pelo Visconde - podemos apontar alguns resultados. A partir da leitura das Bases, vimos que Uruguai possuía uma proposta clara e bem definida de organização do contencioso administrativo, na qual o poder central se valeria dos Presidentes de Província com seus Conselhos e dos os comissários nas localidades para fazer sentir sua ação com maior facilidade. Ademais, segundo a proposta de Uruguai, um agente do Poder Administrativo poderia, conforme discutido no Capítulo 2, impor embaraços à ação dos juízes de paz, principalmente no que dizia respeito às Mesas Eleitorais, pois poderiam os agentes alegar alguma "Razão de Estado" e violação do interesse coletivo para contestar-lhes a legitimidade, ainda que isso não anulasse o poder dos juízes de paz.

Os contornos desse projeto levantam também a questão de por que defender o estabelecimento de agentes administrativos que pudessem crias tais tipos de embaraços se a Lei de 3 de dezembro de 1841 havia municiado o governo central com uma série de cargos que ele poderia ofertar em troca de apoio. Quanto a essa questão, poderíamos a princípio responder que, conforme Uruguai expressa nos Estudos Práticos, sempre havia muita dívida eleitoral a se pagar e mais pessoas para acomodar do que cargos disponíveis. A criação desses agentes, cumpria um importante papel político. Contestar a legitimidade das mesas, mesmo que o resultado dessa contestação não fosse julgado procedente, faria com que questões outrora resolvidas sumariamente pela respectiva mesa se arrastassem por diversos ritos processuais até um julgamento definitivo. É preciso ressalvar que a criação dos agentes não tinha como objetivo necessário fazer essas questões se arrastarem, pois, a depender da situação, também poderia ser interessante ao governo resolvê-las com a maior brevidade. A questão era o poder de pressão que os agentes poderiam dar ao governo, no sentido de municiá-lo quando tivesse de negociar com seus aliados.

Quanto à centralização política, vimos, no Capítulo 3, que, apesar de ser entusiasta da centralização, Uruguai não deixava de reconhecer a importância da esfera provincial de poder, conforme se pode notar da defesa que faz do direito de elas 
legislarem sobre corpos policiais e, inclusive, de criarem jurisdições de primeira e segunda instância para julgar os soldados. O que Uruguai criticava era o excesso de poder das Assembléias provinciais, e daí a defesa de uma maior autonomia das municipalidades. Autonomia tutelada pelo governo central, mas que concorreria com o poder dos legislativos provinciais. Com o mesmo propósito, Uruguai também defendia que o governo central pudesse revogar as leis aprovadas pelas Assembléias Provinciais, ainda que sancionadas pelo Presidente, cabendo a decisão final à Assembléia Geral Legislativa. Com isso, passaria a haver um meio de o governo central impor sua própria vontade ante o poder das Assembléias provinciais.

No que diz respeito à escravidão, ficou claro que foi somente na interpretação de algumas obras da historiografia que Uruguai silenciou sobre o tema. A leitura de seus pareceres na Seção de Justiça e Negócios Estrangeiros e suas falas no Senado mostram não só que não silenciou sobre o tema, mas que possuía um posicionamento claro. Era entusiasta da instituição do cativeiro, estando inclusive envolvido na defesa do contrabando ilegal, o que não o impedia de defender que mesmo os escravos possuíam direitos processuais perante os tribunais.

Ante o exposto nos capítulos desta dissertação, fica claro que a intenção de Uruguai era primordialmente a de fazer o Estado, especialmente a ação do governo central, chegar às mais diversas localidades, ainda que com o auxílio de outras esferas de poder.

Ademais, o estabelecimento e a consolidação da justiça administrativa garantiriam ao governo a possibilidade de ser seu próprio julgador, objetivo para o qual usava a retórica do self-government. Todavia, caso consideremos que não se tratava de mera retórica, fica difícil vislumbrar exatamente como Uruguai pensava o selfgovernment para o Brasil. Em todo caso, esse resultado jamais poderia ser atingido simplesmente pela adoção de princípios estrangeiros, pois "não vale a lei sem costume, vale o costume sem a lei”. Para Uruguai, criar o costume em um país como o Brasil, que, do ponto de vista institucional, era um Estado em construção, só poderia ser feito uma vez consolidado um Estado forte, capaz de se impor por todo o vasto território da antiga América Portuguesa. Por sua vez, esse Estado somente poderia atingir seu fim último de educar o povo para o autogoverno por meio de um partido forte, que se 
impusesse sobre as demais forças políticas. Porém, a dificuldade residia no fato de que, ao ser montado, o sistema pelo qual os saquaremas poderiam se impor tornava-os dependentes de apoios que só poderiam ser obtidos a partir da troca por cargos. Para tomar de empréstimo os termos de Ilmar Rohloff de Mattos, para "governar o Estado", os saquaremas dependiam do "governo da Casa", que se pretendia cooptar para sua órbita, o que em muitos casos significava conflito com esse mesmo governo da Casa. A crescente intervenção de Pedro II na política dos gabinetes foi um golpe para os saquaremas, pois, uma vez que o monarca se mostrava disposto a acabar com o patronato executivo, isso limitava a capacidade de o gabinete angariar apoio e assim, no longo prazo, domesticar o governo da Casa.

Uruguai faleceu a 15 de julho de 1866 . No dia seguinte à sua morte, o Senado e a Câmara dos Deputados suspenderam suas sessões após breves pronunciamentos em homenagem ao Visconde. Ele morreu em um contexto político bastante diferente daquele em que fora aprovada a Lei de 3 de dezembro ou mesmo das discussões, na Câmara dos Deputados, acerca do fim do tráfico negreiro intercontinental. Uma nova geração de políticos começava a despontar, e a Liga Progressista, transformada em Partido Progressista por Zacarias de Góis e Vasconcelos, estava em seu apogeu. Apenas dezoito dias após a morte de Uruguai, Zacarias ascendeu à Presidência do Conselho pela última vez, e sua queda, em 1868, teve diversas conseqüências políticas para a configuração partidária do Império. Pouco depois, em 1870, já se iniciaria a campanha pelo Ventre Livre, e o Manifesto Republicano se tornaria assunto do dia. Com Uruguai, mais do que um político imperial, morria o antigo tempo saquarema. 


\section{FONTES E BIBLIOGRAFIA}

\section{Fontes}

$\underline{\text { Internet }}$

Anais do Senado (1853 - 1866)

Anais da Câmara dos Deputados (1853-1866)

Atas do Conselho de Estado (1853-1866). Versão eletrônica da coleção Atas do

Conselho de Estado. Brasília, Senado Federal, 1978, 13 vols. José Honório Rodrigues (dir.)

Coleção de Leis do Império do Brasil

Limites com a Guiana Francesa: Protocolo sobre a respectiva Negociação em 1855 e 1856. In: Relatório do Ministério dos Negócios Estrangeiros, 1857. Disponível em: http://brazil.crl.edu/bsd/bsd/hartness/minopen.html.

Relatórios Ministeriais. Disponíveis em:

http://brazil.crl.edu/bsd/bsd/hartness/minopen.html

Relatórios de Presidência de Província. Disponíveis em:

www.crl.edu/content/provopen.htm

\section{$\underline{\text { Impressas }}$}

ANDRADA e SILVA, José Bonifácio de. "Representação à Assembléia-Geral Constituinte e Legislativa do Império do Brasil sobre a escravatura", in: Projetos para o Brasil. Org. Miriam Dolhnikoff. São Paulo: Companhia das Letras, 1998.

BLAKE, Sacramento, Dicionário bibliográphico brazileiro Rio de Janeiro, Thipographia Nacional 1888-1902. v.6 p. 354.

BONAVIDES, P. e AMARAL, R., Textos Políticos da História do Brasil. Volumes 1,2 e 8. Brasília, Senado Federal, 2002.

BRASIL, Secretaria de Estado dos Negócios Estrangeiros, $O$ Conselho de Estado e a Política Externa do Império: Consultas da Seção dos Negócios Estrangeiros: 1858-1889. Brasília, FUNAG, 2005 a 2009.

BRASIL, Conselho de Estado (1842-1889), Consultas da Seção dos Negócios Estrangeiros. Brasília, Câmara dos Deputados, 1981.

CAROATÁ, J.P.J.S., Imperiaes Resoluções Tomadas Sobre Consultas da Seção de Justiça do Conelho de Estado. Rio de Janeiro : B L Garnier, 1884.

CORREA, M.F., Consultas do Conselho de Estado Sobre Negócios Eclesiásticos. Rio de Janeiro, Typographia Nacional, 1869-1870. 
FILGUEIRAS JÚNIOR, A., Código do Processo do Império do Brasil. Tomo I e Tomo II. Rio de Janeiro, Carlos e Henrique Laemmert, 1874.

FUNAG: O Conselho de Estado e a Política Externa do Império. Consultas da Seção dos negócios Estrangeiros (1858-1862). Rio de Janeiro, Fundação Alexandre de Gusmão.

MACEDO, J.M., Necrológio do Visconde do Uruguai in: Revista do Instituto Histórico e Geográfico Brasileiro. Tomo 29, Volume 33, 1866, p.p. 471-478. Rio de Janeiro, Garnier.

MACEDO, J.M., Visconde do Uruguai. Ano Biográfico Brasileiro, v.3 p. 185

MELLO, B.B.P. Imperiaes Resoluções Tomadas Sobre Consultas da Seção de Justiça do Conelho de Estado Desde o Anno em que Começou a Funcionar o Dito Conselho. Rio de Janeiro, Typographia Nacional, 1877.

Diário do Imperador Dom Pedro II in: Anuário do Museu Imperial. Petrópolis, Ministério da Educação e Cultura, 1956.

LYRA, A.T. Consultas do Extincto Conselho de Estado Sobre Assumptos de Competência do Ministério da Justiça. Rio de Janeiro, Imprensa Nacional, 1907.

PIMENTA BUENO, J. A., Direito Público Brasileiro e Análise da Constituição do Império. In: KUGELMAS, E., Marquês de São Vicente. São Paulo, Editora 34, 2002.

REGO, V.P. Elementos de Direito Administrativo Brasileiro, Para Uso nas Faculdades de Direito do Império. Recife, Typographia Commercial de Geraldo Henrique e Mira \& C. 1860.

RIBAS, A.J., Direito Administrativo Brasileiro: Noções Preliminares. (Obra premiada e aprovada pela Resolução Imperial de 9 de fevereiro de 1861 para uso das aulas das Faculdades de Direito de Recife e São Paulo). Rio de Janeiro, F.L. Pinto \& C., Livreiros-Editores 87, 1866.

Cartas entre Paulino José Soares de Souza e Bernardo Pereira de Vasconcelos publicadas em: SOUZA, J.A.S., A Queda de Rosas in: Revista do Instituto Histórico e Geográfico Brasileiro, Volume 264 Julho-Setembro, 1964. Rio de Janeiro, Imprensa Nacional, 1965.

SILVA, Inocêncio Francisco Dicionário bibliográfico português Lisboa: Imprensa Nacional, 1858-1923. v.6 p. 361 v. 17 p. 150.

SOUZA, P.J.S. Três Discursos de Ilmo. e Exmo. Sr. Paulino José Soares de Souza,

Ministro dos Negócios Estrangeiros. Rio de Janeiro: Typographia Imperial e Constitucional de J. Villeneuve e Companhia, 1852.

SOUZA, J.A.S., Cartas de Justiniano José da Rocha ao Visconde do Uruguai in: Revista do Instituto Histórico e Geográfico Brasileiro, Volume 220 JulhoSetembro, 1953. Rio de Janeiro, Imprensa Nacional, 1954.

SOUZA, J.A., Cartas de D. Antônio Ferreira Viçoso, Bispo de Mariana ao Visconde do Uruguai in: Revista do Instituto Histórico e Geográfico Brasileiro, Volume 242. Rio de Janeiro, Imprensa Nacional, 1960.

SOUZA FILHO, C.F.S., Processo Criminal in: RAMALHO, Joaquim Ignácio; BAPTISTA, Francisco de Paula; SOUZA FILHO, Clemente Falcão de. Postillas de prática: colleção completa das licções de pratica do anno de 1865, precedidas de cinco licções de hermeneutica juridica e seguidas de dez de processo criminal, 
inteiramente correctas (sic). 2. ed. São Paulo: Typographia Americana, 1872.

Disponível em: http://bdjur.stj.jus.br/xmlui/handle/2011/2042.

TAVARES BASTOS, A.C., A Província. São Paulo, Companhia Editora Nacional/ Instituto Nacional do livro, 1975

TAVARES BASTOS, A.C., Cartas do Solitário. Rio de Janeiro, Histórico e Geográfico Brasileiro, Volume 313, Outubro-Dezembro - 1976. Rio de Janeiro, Departamento de Imprensa Nacional, 1977.

TOCQUEVILLE, A., A democracia na América. Belo Horizonte: Edusp/Itatiaia, 1977

URUGUAI, V., Bases Para Melhor Organização das Administrações Provinciais. Rio de Janeiro, Garnier, 1858.

URUGUAI, V., Ensaio Sobre o Direito Administrativo. in: CARVALHO, J.M. (ORG), Visconde do Uruguai. São Paulo, Editora 34, 2002.

URUGUAI, V., Estudos Práticos Sobre a Administração de Províncias do Brasil. Rio de Janeiro, Typographia Nacional, 1865.

VASCONCELOS, Z.G., Da Natureza e dos Limites do Poder Moderador. in: OLIVEIRA, C.H.S. (ORG), Zacarias de Góis e Vasconcelos. São Paulo, Editora 34, 2002.

$\underline{\text { Manuscritas }}$

\section{Instituto Histórico e Geográfico Brasileiro}

Arquivo Visconde do Uruguai

1) Sousa, Paulino José Soares de: Aviso de P.J.S.S. a Cândido José de Araújo Viana, informando que a Secretaria dos Negócios Estrangeiros Franqueará seus documentos ao $2^{\circ}$ Barão de Cairu, a fim de que possa desempenhar a comissão de que o encarregou o IHGB. Lata 574 Pasta 14.

2) Sousa, Paulino José Soares de: Bilhete de Souza Carvalho dando e pedindo informações sobre pretendentes a colocações e títulos, inclusive sobre a possibilidade de uma pensão às filhas do Visconde do Uruguai. Lata 214 - Doc 22.

3) Sousa, Paulino José Soares de: (1852): Bilhete do Visconde de Cachoeira ao Cons. P.J.S.S., enviando uma letra e uma minuta. (Não acompanham os documentos citados). Lata 351 Doc. 67.

4) Sousa, Paulino José Soares de: (Visconde do Uruguai) Biografia de ... OBS: Coleção Ourém em francês. Lata 146 Doc 26.

5) Sousa, Paulino José Soares de: (Visconde do Uruguai) Biografia de ... OBS: Coleção Ourém em francês. Lata 144 Doc 12.

6) Sousa, Paulino José Soares de: Biografia do Visconde do Uruguai. Impresso. Galeria dos Brasileiros Ilustres. Arm.1 Gav.1 nº55.

7) Sousa, Paulino José Soares de: Carta confidencial de H.H.C. Leão ao Ministro P.J.S.S. em que se refere à divisão brasileira, às desavenças com Urquiza e unitários e às condenações em massa. Montevidéu, 5/3/1852. Lata 748 Pasta 34.

8) Sousa, Paulino José Soares de: Carta do Visc. De Paraná ao Visconde do Rio Branco, sobre o Barão de Mauá, e empréstimo ao Estado Oriental. Carta de P.J.S.S. ao Visconde do Rio Branco sobre o mesmo assunto. Lata 515 Pasta 14 
9) Sousa, Paulino José Soares de: Carta de P.J.S.S. ao cons. Nabuco de Araújo, solicitando atenda ao pedido de seu amigo Dr. Francisco de Sá Brito. Lata 367 Pasta 55.

10) Sousa, Paulino José Soares de: Carta de Poder geral e especial pela qual VMI há por bem nomear seu plenipotenciário ao Visconde do Uruguai para negociar com os plenipotenciários da Confederação Argentina e da República Oriental do Uruguai um tratado definitivo de aliança e regular seus respectivos direitos e obrigações; 15/10/1858. Arm. 1 Gav. 1 n 69.

11) Sousa, Paulino José Soares de:Carta de poder geral pala qual VMI há pó bem nomear seu plenipotenciário ao Visconde do Uruguai para que possa estipular, concluir e firmar até o ponto de ratificação com o plenipotenciário ou plenipotenciário que nomear S.M. o Imperador dos Franceses um tratado de limites entre o Brasil e a Guiana Francesa. Ar.1 Gav.1 Doc 66

12) Sousa, Paulino José Soares de:Carta de poder geral pala qual VMI há pó bem nomear seu plenipotenciário ao Visconde do Uruguai para que possa tratar da revisão do tratado de comércio e navegação existente Entre o Império do Brasil e a República Oriental do Uruguai. 30/05/1857. Arm.1 Gav.1 Doc nº 67.

13) Sousa, Paulino José Soares de: carta dirigida do Rio de Janeiro a Saraiva pelo ... declarando-lhe o alto conceito em que o tinha. 12/12/1859. Lata 270 Doc. 44

14) Sousa, Paulino José Soares de: Carta do V.U. ao Cons. Nabuco de Araújo acerca dos serviços prestados por Joaquim de Paula Guedes Alcoforado ao Gabinete Iataboraí (1852), do qual fizera parte 4/10/1853. Lata 365 Pasta 108.

15) Sousa, Paulino José Soares de: Carta do V.U. ao Dr. Inocêncio Góes pedindo apoio para a candidatura do Dr. José Antonio de Magalhães e Castro à Assembléia Geral. (1856). Lata 554 Pasta 68

16) Sousa, Paulino José Soares de: Carta do Visconde do Uruguai, refutando acusação de F.P. Silveira Lobo de lhe haverem sido concedidos vencimentos indébitos pelo Cons. Nabuco de Araújo. (1857) Lata 381 Pasta 54.

17) Sousa, Paulino José Soares de: Carta do V.U. solicitando ao Cons. Nabuco de Araújo a promoção a $1^{\circ}$ Conferente da Alfândega de seu filho José Antonio Soares de Sousa. Rj, 24/6/1865. Lata 365 Pasta 109.

18) Sousa, Paulino José Soares de: Cartas confidenciais e ofício reservado de H.H.C.Leão ao Ministro P.J.S.S. sobre: o convenio de 21/11/1851, o incidente entre Honório e Urquiza; a candidatura de Herrera e $1^{\text {a }}$ entrevista com 0 Presidente Garzon. Monteviséu-Buenos Aires. 1851-52. Lata 748 Pasta 33.

19) Sousa, Paulino José Soares de: Cartas de P.J.S.S. ao Marquês de Olinda: fazendo e atendendo a pedidos, remetendo trabalhos, etc. $\mathrm{Rj}, 1851 / 58$ (8 cartas). Lata 214 Doc. 68.

20) Sousa, Paulino José Soares de: Cartas de ... e outros, dirigidas ao Desembargador Francisco Marques de Araújo Góes, Cons. Inocêncio Marques de Araújo Góes, Dr. José de Góes, Dr. José de Góes e Siqueira e Desembargador Miguel Calmon du Pin e Almeida. (14 cartas) Lata 135 Doc. 5.

21) Sousa, Paulino José Soares de: Cartas dos Ministros de Estado. Cartas do Ministro de Estrangeiros P.J.S.S. ao Cons. J.T. Nabuco de Araújo. 6 docs. Lata 367 Livro 1 p.p. 97 a 102. 
22) Circular assinada por P.J.S.S. comunicando, em nome do Imperador, o falecimento de S.A. a Princiesa D. Maria Amélia, ocorrido em 4/2/1853 721. Lata 721 Pasta 18.

23) Sousa, Paulino José Soares de: (1865): Conferência da Seção dos Negócios Estrangeiros do Conselho de Estado sobre o Tratado de Paz oferecido pelo governo da Argentina. Lata 312 Pasta 5.

24) Sousa, Paulino José Soares de: Correio Mercantil; prop, de Muniz Barreto, Mendes Campo e Comp. - Discurso do Visconde do Uruguai em Sessão do Senado realizada em 27 de janeiro de 1864; sessão do Senado em 20 de fevereiro de 1864. Arm, 5 Gav. 2 doc. n54.

25) Sousa, Paulino José Soares de: Dados biográficos do Visconde do Uruguai. Lata 634. Env. 62

26) Sousa, Paulino José Soares de: Dados biográficos de D. Pedro II, Marquês de Olinda, Pedro de Alcântara Belegarde e Visconde do Uruguai. Cópia do livro "Os Contemporâneos", por A.Sisson. RJ, 1861, 8 folhas. Lata 477 Doc. 11.

27) Sousa, Paulino José Soares de: Diploma concedido a... Visconde do Uruguai. pela Loja Grande Oriente do Brasil. Rj, 26/11/1864. Arm.1 Gav.1 doc nº63.

28) Sousa, Paulino José Soares de: diploma de sócio efetivo da Sociedade Auxiliadora da Indústria Nacional conferido a P.J.S.S. Rj, 26/12/1836. Arm.1 Gav.1 Doc. N 59.

29) Discursos do Ministro dos Negócios Estrangeiros P.J.S.S. proferido em sessão do Senado em 1853. Diário do Rio de Janeiro, Ano XXXII nºs 181, 192, 1941853. Rj, 5, 16 e 18/7/1853. Arm. 5 Gav.2 Doc. $\mathrm{n}^{\circ} 52$

30) Sousa, Paulino José Soares de: Galeria dos Ministros do Exterior ... Retrato e Biografia. Rj, 1853 - pag. 9. Lata 749. Doc. 4.

31) Sousa, Paulino José Soares de: Legação Brasileira em Montevidéu. A missão especial de Honório Hermeto Carneiro Leão; o comando da divisão brasileira; a escolha de Paranhos para secretário. 1851-1852 - 7 docs. Lata 750 Pasta 39.

32) Memória sobre os trabalhos que se podem consultar nas negociações de limites do Império, escrita por ordem do Cons. P.J.S.S., ministro e Secretário dos Negócios Estrangeiros por F.A.de V. Cópia datilográfica. Arquivo do Museu Imperial (Oferta do Dr. Alcindo Sodré). 1851 18p. Lata 340 Pasta 6

33) Sousa, Paulino José Soares de: Notas para sua biografia. Col. Ourém.

34) Sousa, Paulino José Soares de: Ofício do Mal. Francisco José de Souza Soares d'Andrea ao Conselheiro ... acompanhando a ata de reunião dos comissários da demarcação de limites entre o Uruguai e o Brasil. 19 de janeiro de 1853. Lata 194 Doc. 24.

35) Sousa, Paulino José Soares de: Ofício (cópia manuscrita) de Zacarias de Góes e Vasconcelos ao Visconde do Uruguai, comunicando-lhe haver sido nomeado presidente da comissão encarregada de julgar o projeto de Código Civil do Dr. Teixeira de Freitas (1864). Lata 388 Pasta 5

36) Ofícios entre P.J.S.S., Francisco Antonio Ribeiro, e o cônsul em Gênova, Ernesto Antonio de Sousa Laconte, a respeito do traficante de escravos Pedro dos Santos, morto a bordo da polaca sarda "Libertas", durante a viagem de Santos para Gênova. 1852, 4 folhas. Lata 490 Pasta 23. 
37) Parecer da S.E. do C.E. sobre o projeto de Convenção Consular apresentado confidencialmente pelo ministro da França desta corte, para terminar amigavelmente a questão pendente entre os dois governos relativamente à inteligência do Art. $1^{\circ}$ adicional ao tratado de 6/6/1826. Assinado pelos Cons. E. de Queiroz, V.U. e v. de Maranguape. Lata 163, Doc. 18.

38) Sousa, Paulino José Soares de: Parecer da S.J. do C.E. a respeito do procedimento do Juiz de Direito da Comarca de Brejo, José Belisário Henriques da Cunha, no processo contra os assassinos do Tenente Roberto Francisco Coelho. Ass: V. de Jequitinhonha, J.A. Pimenta Bueno e V.U. 1865. 46 fls. OBS: Resolução de 28 de novembro de 1865. Lata 371 Pasta 29.

39) Parecer da S.E. do C.E. acerca do projeto de tratado de paz proposto pela Argentina para ser celebrado com o Paraguai, com comentários acerca do estabelecimento da aliança com a Argentina. Cópia da época. Ass: P. Bueno, V.U., e V. de Jequitinhonha. 30/11/1865. Lata 372 Pasta 27.

40) Parecer das Seções de Fazenda e Justiça do Conselho de Estado acerca das medidas de combate à crise bancária. Ass: P. Bueno, V.U., M. de Abrantes, V. de Itaboraí, V. de Jequitinhonha e Cândido Batista de Oliveira. 10/9/1864. Lata 377 Pasta 13.

41) Parecer de P.J.S.S., Seção de Fazenda do Conselho de Estado. Recurso de Diogo de Paria Coelho, sobre comissões de compra e venda de escravos. 1885, 5p. Lata 319 Pasta 32.

42) Sousa, Paulino José Soares de: Parecer de P.J.S.S. nas Seções reunidas do Império, Fazenda e Justiça sobre a propriedade da superfície e do interior das terras, para elaboração de uma lei que regule a mineração nacional. Rj, maio de 1860. Lata 213 Doc. 108.

43) Sousa, Paulino José Soares de: Recibo de venda de um escravo, efetuada em 1853, pelo procurador do Sr. P.J.S.S. ao Sr. Rufino Antonio Nunes. Rj, 15/10/1853. Lata 965. Pasta 110.

44) Sousa, Paulino José Soares de: Traços Biográficos de P.J.S.S., V.U. Lata 560 Pasta 21.

45) Sousa, Paulino José Soares de: Voto do Marquês de Olinda em Parecer sobre poderes da Assembléia Provincial das Alagoas; carta do V.U. aprovando o mesmo voto, contra a opinião do Marquês de Sapucaí e de Pimenta Bueno. RJ, 1861/62. Col. Marquês de Olinda. Lata 211 Doc. 57.

46) Sousa, Paulino José Soares de: Trê Brasileiros ilustres: José Antonio Soares de Sousa, Visconde do Uruguai e Cons. Paulino José Soares de Sousa. Contribuições biográficas de Álvaro Paulino Soares de Sousa por ocasião do centenário da iindependência. 1922. Lata 497 Doc. 2

Coleção Nabuco:

Arquivos e Coleções Particulares - ACP

Senador Nabuco 
Período abrangido pelo arquivo: 1654-1905 - 5.664 docs. Instrumentos: inventário analítico, índices onomástico e de assuntos, fichário. ACP 36

\section{NABUCO: CORRESPONDÊNCIA MINISTERIAL:}

570: Pimenta Bueno: cartas sobre temos do processo criminal. DL 367.15

623: Cartas de Rodrigues Torres: 1849-52; DL 367.1 P.P. 91-97

619: Paulino: cartas 367.55 e 367.1 p.p. 97 a 102

795: Pareceres do Conselho de Estado sobre a escravidão 1852-65 1 doc 78p DL 374.5

798 Sobre direitos processuais decreto: DL 374.8

956: Ofícios de Justiça DL 380.3

950: Bases Para Melhor Organização das Administrações Provinciais, Visconde do Uruguai, 1858; DL 379.3

1012: Carta do Visconde do Uruguai refutando a acusação de lhe haverem sido concedidos vencimentos indébitos pelos Conselheiros Nabuco de Araújo, Ministro da Justiça. Acompanha carta do Deputado Silveira Lobo respondendo ao Visconde do Uruguai. 1857. DL 381.54

1033: Docs Sobre extradição. DL 383.3

1064: Notícias da dissolução do gabinete Itaboraí; programa de governo de Paraná ... DL 385.8

1067: Programa do gabinete da conciliação

1077: Programa do Partido Progressista: DL 385.22

1115: Projetos de Reforma eleitoral 1869 DL 386.9

1117: PENA DE MORTE: Leis, Ofícios, decretos ... DL 386.11

1123: Pimenta Bueno: Exposição de motivos, projeto e comentários ... CONSELHOS

DE PRESIDÊNCIAS DE PROVÍNCIA. DL 386.18

1162: VASCONCELOS, Zacarias de Góes: Ofício ao Visconde do Uruguai haver sido nomeado presidente da Comissão encarregada de julgar o projeto de Código Civil de Teixeira de Freitas.

1181: REFORMA JUDICIÁRIA: Provas Tipográficas do Projeto de Reforma... com detalhados pareceres de diversas personalidades. DL 389.2

1182: Documentação Compilada pelo Cons. Nabuco DL 389.3

1192: RIO AMAZONAS. Documentos Relativos à navegação dos rios amazônicos a bandeiras estrangeiras. 1854-66. DL. 390.7

1199 a 1202: Conselho de Estado: Pareceres da Seção de Justiça do Conselho de Estado DL 391.1 a 391.4

713: CUNHA, JOSÉ BELISÁRIO HENRIQUES. Parecer da Seção de Justiça do Conselho de Estado. DL 371.29

773: GUERRA DO PARAGUAI. Parecer da Seção dos Negócios Estrangeiros do

Conselho de Estado. DL 372.28 


\section{Arquivo Nacional: Documentação referente ao Conselho de Estado (1853-} 1866) ${ }^{482}$.

- 295. Atas da criação do $1^{\circ}$ Conselho (Microfilmado) (1822-1823);

- 296/1-2. Assentamentos dos Conselheiros (1866-1889);

- 297/1-2. Protocolo (1860-1878);

- 52/1-3. Registro das Consultas Livro Tombo (1845-1860).

- 283. Ordens Imperiais ao Conselho (1842-1876);

- 299. Ordens Imperiais Registros (1842);

- 300/1-4. Sinopses Índices das Consultas diversos assuntos (1859-1870);

- 301/1-4. Consultas Seção de Justiça (1842-1872);

- 302/1-2. Registros de Avisos aos Conselheiros (1844-1859);

- 303/1-5. Protocolos das Consultas das Seções de Justiça (1861-1889);

- 306/1-48. Consultas Seção de Justiça (1843-1879);

- 760/1-2. Abertura de rios à navegação comercial (1854-1867)

- 782. Autos do processo-crime Mota Coqueiro (Microfilmado) (1852-1855)

- 969. Consultas Casamentos Mistos (Microfilmado) (1849-1857)

- 1080. Juramentos dos Advogados (1842)

\section{Biblioteca Nacional: Coleção Tobias Monteiro:}

2.323: URUGUAI: Visconde do: Carta a seu filho falando sobre questões eleitorais, da morte do marquês do Paraná e da crítica situação política em que se encontra o ministério, além de tratar de assuntos pessoais. Paris/RJ 14/07/1856-13/01/1857. 7 docs. 22p. 63, 04, $002 \mathrm{n}^{\circ} 110$.

2.322: URUGUAI, P.J.S.S., Visconde do: Cartas ao conselheiro P.J.S.S., seu filho, transmitindo-lhe os elogios que recebeu do Visconde de Monte Alegre, recomendando que se empenhe mais nos estudos e explicando a dificuldade da profissão de redator de jornais. 13p. Rj, 19/0/1852 - 03/05/1854. 63,04,002 nº 109

2.293: URUGUAI, P.J.S.S., Visconde do: Autobiografia do Visconde do Uruguai. 12p. $63,04,001 \mathrm{n}^{\circ} 47$

482 Índice dos Códices da Antiga SDH por Fundo Conselho d'Estado. 
2.243: PEDRO II, Imperador do Brasil. Bilhetes ao Visconde do Uruguai pedindo notícias do Conselho de Estado, comentando a Lei Eleitoral e o envio de diversos documentos, entre outros assuntos. 29p. 63,03,006 $\mathrm{n}^{\circ} 059$.

\section{Bibliografia}

ABREU, E.S.A., O Evangelho do Comércio Universal: O Desempenho de Tavares Bastos na Liga Progressista e no Partido Liberal (1861-1872). Tese de Doutoramento, IFCH/UNICAMP, 2004.

AMBROSINI, D.R., Organização do Poder no Brasil - O debate sobre o Poder Moderador. 2004. 0 f. Dissertação (Mestrado em Ciência Política) - Universidade de São Paulo, . Orientador: Gildo Marcal Bezerra Brandao.

ARBILLA, J.M., A neutralidade limitada: o Império do Brasil e a divisão Argentina (1852-62). in: Revista Múltipla NÚMERO 10 - ANO VI - 2001. pp. 55-78.

ATTIYA, P.S., The Rise and Fall of Freedom of Contract. Oxford, Claderon Press.

AUBERT, E.H. Vidas de Dante. Escritos Biográficos dos séculos XIV e XV. São Paulo, Ateliê Editorial e FAPESP, No Prelo.

AZEVEDO, D.A. A natureza jurídica das associações de municípios e dos consórcios intermunicipais http://www.mj.gov.br/snj/oscip/publicacoes/natureza juridica2.pdf

BARBOSA, Silvana Mota, A sphinge monárquica: o poder Moderador e a política imperial. Tese de doutoramento. Campinas, Unicamp, 2001.

BARMAN, Roderick J. Citizen emperor. Pedro II and the making of Brazil, 1825-91. Stanford, California: Stanford University Press, 1999.

BARRETO, Tobias. A questão do Poder Moderador. (Edição organizada por Evaristo de Moraes Filho). Petrópolis: Vozes, 1977

BASILE, M.O.N.C., O Império em construção: projetos de Brasil e ação política na corte regencial. 2004. Tese (Doutorado em História Social) - Universidade Federal do Rio de Janeiro, Fundação de Amparo a Pesquisa do Estado do Rio de Janeiro. Orientador: Jose Murilo de Carvalho.

BASTOS, T., A Província. São Paulo, Companhia Editora Nacional/ Instituto Nacional do livro, 1975.

BEIGUELMAN, Paula, Formação Política do Brasil. São Paulo, 1967, 2 vols. A destruição do escravismo moderno como questão teórica in: Pequenos Estudos de Ciência Politica. São Paulo, 1967.

BENTIVOGLIO, J., O Império das circunstâncias: o Código Comercial e a política econômica brasileira (1840-1860). Tese de doutorado em História Econômica, cuja pesquisa foi financiada pela Fapesp, defendida na FFLCH da USP em dezembro de 2002 sob orientação da Profa. Dra. Raquel Glezer.

BERBEL,M.R. MARQUESE, R.B. PARRON, T.P. Escravidão e Política. Brasil e Cuba, 1780-1850. São Paulo: Hucitec e Fapesp, 2010.

BETHELL, L. A abolição do tráfico de escravos no Brasil: a Grã-Bretanha, o Brasil e a questão do tráfico de escravos, 1807-1869. São Paulo, EDUSP, 1976;

BETHELL, L. e CAVALHO, J.M., O Brasil da Independência a Meados do Século XIX in: in: Bethell, L. (org.), História da América Latina, Da Independência a 1870. São Paulo, EDUSP e Imprensa Oficial, 2001 
BORJA, Célio. "Introdução". In: SOUSA, Paulino José Soares de (Visconde de Uruguai), Ensaio sobre o Direito Administrativo. $3^{\mathrm{a}}$. Edição, Brasília: Ministério da Justiça, 1997.

BONAVIDES, P.A.., AMARAL, R., Textos Políticos da História do Brasil. Brasília, Senado Federal, 2002.

BOURDIEU, P., A ilusão biográfica. In: FERREIRA, Marieta de Moraes \& AMADO, Janaína (orgs.), Usos e Abusos da História Oral. Rio de Janeiro, Fundação Getúlio Vargas, 1996.

BOURDIEU, P., O Poder Simbólico. Rio de Janeiro, Bertrand Brasil, 1998.

BRINKLEY, A., Comparative Biography as Political History: Huey Long and Father Coughlin. in: The History Teacher. Vol, 18, nº1 (Nov. 1984), p.p. 9-16.

BURKE, E. Reflexões Sobre a Revolução em França, UnB, Brasília, 1997.

CABRAL, M. V. O exercício da cidadania política em perspectiva histórica (Portugal e Brasil) Revista Brasileira de Ciências Sociais, v.18 n.51 São Paulo feb. 2003. Disponível em: http://www.scielo.br/scielo.php?script=sci_arttext\&pid=S010269092003000100005\&lng=es\&nrm=iso\&tlng=pt

CALÓGERAS, J.P., A Política Exterior do Império. V.3. Brasília, Senado Federal, 1998.

CANDIDO, A., Literatura e Sociedade. Coleção Grandes Nomes do Pensamento Brasileiro. São Paulo, Folha de São Paulo, 2000.

CARDOSO, F.H. Capitalismo e escravidão no Brasil meridional: o negro na sociedade escravocrata do Rio Grande do Sul. São Paulo: Difusão Européia do Livro, 1962

CARVALHO, J.M., Entre a Autoridade e a Liberdade. in: CARVALHO, J.M. (ORG), Visconde do Uruguai. São Paulo, Editora 34, 2002.

CARVALHO, J.M., A Construção da Ordem, Civilização Brasileira. Rio de Janeiro, 2003.

CARVALHO, J.M. Teatro de Sombras, Civilização Brasileira. Rio de Janeiro, 2003.

CARVALHO, J.M., A Utopia de Oliveira Vianna in: BASTOS, E.R. e MORAES, J.Q. (orgs) O Pensamento de Oliveira Vianna. Campinas: Editora da Unicamp, 1993pp.13-43.

CARVALHO, J.M., Federalismo y centralización en el Imperio brasileño: historia y argumento in: CARMANGNANI, M. (coord) Federalismos latinoamericanos: México, Brasil, Argentina. México, Fondo de Cultura Económica, 1993, pp.51-80.

CARVALHO, J.M., Introdução in: CARVALHO, J.M. (org.) Bernardo Pereira de Vasconcelos. São Paulo, Editora 34, 1999.

CARVAlHO, M.J.M. A Insurreição Praieira in: Revista Almanack Braziliense, n. 8, nov. de 2008, p. 17. Disponível em: www.almanack.usp.br.

CAVALCANTI, T.B., Apresentação in: SOUSA, Paulino José Soares (Visconde de Uruguai), Ensaio sobre o Direito Administrativo. $2^{\mathrm{a}}$.Edição, Rio de Janeiro: Imprensa Nacional, 1960, pg. I - X.

CASTRO, P.P., A Experiência Republicana in: HOLANDA, S.B. (org.), História Geral da Civilização Brasileira - Dispersão e Unidade (tomo II, O Brasil Monárquico, volume 4). São Paulo, Diefel, 5ª Edição, 1985. 
CASTRO, P.P., Política e Administração: 1844-1848 in: HOLANDA, S.B. H (org) História Geral da Civilização Brasileira Volume 6. Bertrand Brasil, Rio de Janeiro, 2004.

CENTRO DE DOCUMENTAÇÃO DO PENSAMENTO BRASILEIRO. "Soares, Paulino José (Visconde do Uruguai)". In: Dicionário Biobibliográfico de Autores Brasileiro - Filosofia, Pensamento Político, Sociologia, Antropologia. (Apresentação de Antônio Paim), Salvador: CDPB; Brasília: Senado Federal, 1999. pg. 457-458.

CHALHOUB, S. Visões da liberdade: uma história das últimas décadas da escravidão na corte. São Paulo: Companhia das Letras, 2001.

CLAVERO, B. Happy Constitution, Cultura y Lengua Constitucionales. Madrid, Editorial Trota, 1997.

CONSTANT, B., Da liberdade dos antigos comparada à liberdade dos modernos, in Filosofia Política (Porto Alegre: LPM Editores, 1985.

CONRAD, R. Os últimos anos da escravatura no Brasil. Rio de Janeiro, Civilização Brasileira, 1978.

COSER, I., Visconde do Uruguai, Centralização e Federalismo no Brasil, 1823-1866. Belo Horizonte, Editora UFMG, 2008.

COSER, I. . As Estratégias para Reforma do Estado : o modelo Bresser. Administração e Sociedade- Revista do Mestrado em Administração da Universidade Federal Fluminense, Nitéroi, v. 1, p. 3-123, 1999.

COSER, I., O pensamento político do Visconde do Uruguai e o debate entre centralização e federalismo no Brasil (1822-1866). 2006. Tese (Doutorado em Ciência Política (Ciência Política e Sociologia)) - Sociedade Brasileira de Instrução - SBI/IUPERJ, Fundação de Amparo a Pesquisa do Estado do Rio de Janeiro. Orientador: Marcelo Gantus Jasmin.

COSTA, C.O Arquivo Público do Império: o Legado Absolutista na Construção da

Nacionalidade. In: Estudos Históricos, vol. 14, n²6. Rio de Janeiro, 2000. Disponível

em: http://www.bibliotecadigital.fgv.br/ojs/index.php/reh/article/download/2123/1262

COSTA, E.V., Da Monarquia à República: Momentos Decisivos. São Paulo, UNESP, 2007.

COSTA, W.P., Dicionário Biográfico de Pernambucanos Célebres. Recife, Tipographia Universal, 1882.

COSTA, W.P. Finanças e construção do Estado in América Latina en la Historia Economica, num. 13 enero-deciembre de 200 p.51-65 http://www.institutomora.edu.mx/revistas/Numero\%2013-14/13-4WilmaPeresCosta.pdf

COSTA, W.P., Economia primário-exportadora e padrões de construção do Estado na Argentina e no Brasil. in: Economia e Sociedade, Campinas, (14), jun. 2000. pp.175-202.

DALLARI, D.A., O Conselho de Estado e o Contencioso Administrativo no Brasil. In: Revista de Direito Público. São Paulo, Editora Revista dos Tribunais, 1970, Janeiro/Março, Volume 11.

DUBOIS, Laurent, A Colony of Citzens. Chaplel Hill: University of North Carolina Press, 2004. 
DANTAS, M.D., Para além "centros" e "periferias": autoridades locais, poder judiciário e arranjos políticos no Império do Brasil (o caso de uma comarca da província da Bahia). In: Seminário: De um Império a Outro, $3^{\mathrm{a}}$ Parte, Mesa 2. Disponível em: WWW.esdadonacional.usp.br.

DANTAS, M.D., "Constituição, poderes e cidadania na formação do Estado-nacional brasileiro", Rumos da Cidadania, Instituto Prometeus, p. 19. Cópia cedida pela autora.

DANTAS, M.D. "O código do processo criminal e a reforma de 1841: dois modelos de organização do Estado (e suas instâncias de negociação)". Conferência apresentada junto ao IV Congresso do Instituto Brasileiro de História do Direito Autonomia do direito: configurações do jurídico entre a política e a sociedade, São Paulo, Faculdade de Direito/ USP, 2009.

DOHLNIKOFF, M., Caminhos da conciliação : o poder provincial em São Paulo, 1835-1850 Dissertação de Mestrado apresentada à área de História Econômica do Departamento de História da Faculdade de Filosofia, Letras e Ciências Humanas da Universidade de São Paulo. São Paulo, 1993.

DOHLNIKOFF, M., O Pacto Imperial: Origens do Federalismo no Brasil. São Paulo, Editora Globo, 2005.

DURKHEIM, E., As Regras do Método Sociológico. São Paulo, Martins Fontes, 1995.

EL - KAREH, A.C., A Companhia de Navegação e Comércio do Amazonas e a Defesa da Amazônia Brasileira: "O Imaginado Grande Banquete Comercial”. In: Revista do instituto Histórico e Geográfico Brasileiro. Rio de Janeiro, n 418, jan/mar. 2003. Disponível em: http://www.ihgb.org.br/rihgb/rihgb2003numero0418c.pdf

ESTEFANES, B.F. Conciliar o Império: Honório Hermeto Carneir, os Partidos e a Política de Conciliação no Brasil Monárquico(1842-1856). Dissertação de Mestrado, São Paulo, 2010. Disponível em: http://www.teses.usp.br/teses/disponiveis/8/8138/tde-10012011-122904/fr.php

FASSÓ, G. Jusnaturalismo in: : BOBBIO, N. MATTEUCCI, N. PASQUINO, G. Dicionário de Política. Brasília, Editora UnB, 1998.

FASSÓ, G. História de La Filosofia Del Derecho. Madrid, Ediciónes Piramide, 1966.

FALBO, R.N., Contradições e Ambigüidades no Brasil Imperial. O Dilema dos

Advogados na Justiça. 2004. Tese (Doutorado em Sociologia) - Sociedade Brasileira de Instrução - SBI/IUPERJ, Coordenação de Aperfeiçoamento de Pessoal de Nível

Superior. Orientador: Marcelo Gantus Jasmin.

FERNANDES, F. O negro no mundo dos brancos. São Paulo: Difel, 1971.

FERREIRA, G.N., Centralização e Descentralização no Império: o Debate Entre Tavares Bastos e Visconde de Uruguai. São Paulo, Editora 34 e Departamento de Ciência política da USP, 1999.

FERREIRA, G.N., O Rio da Prata e a Consolidação do Estado Imperial. São Paulo, Editora Hucitec, 2006.

FERREIRA, G. N. ; MOTA, Carlos Guilherme . O coração do Estado Imperial. In: Carlos Guilherme Mota. (Org.). Os Juristas na formação do Estado-Nação brasileiro -Séc. XVI a 1850 - Coleção Juristas Brasileiros. São Paulo: Quartier Latin, 2006.

FERREIRA, G.N. e RICUPPERO, B. Estado e Sociedade em Oliveira Vianna e Raymundo Faoro. Caderno CRH Salvador, v. 18 n.44 Maio/Agosto 2006. 
FIORAVANTI, M. Constituición, De La Antiguedad a Nustros Días. Madrid, Trota, 2001.

FLORY, T., El Juez de Paz y El Jurado em El Brasil Imperial, 1808-1871 Control y estabilidad política em el nuevo Estado, Fondo de Cultura Económica, México, 1986.

FONER, E., Nada Além da Liberdade: A Emancipação e Seu Legado. Rio de Janeiro, Paz e Terra, 1988.

FOURNIER, M., Para Reescrever a Biografia de Marcel Mauss. In: Revista Brasileira de Ciências Sociais. São Paulo, ANPOCS, junho/2003, Volume 52.

FRANCO, M. S.C., As idéias estão no lugar (1976) in: Cadernos de Debate, 1, História do Brasil. São Paulo, Brasiliense.

GADDIS, J.L., Paisagens da História, Como os Historiadores Mapeiam o Passado. Rio de Janeiro, Editora Campos, 2003.

GARNER, L., "In Pursuit of Order: The Section of Empire of the Council of State, 1842-1889." Tese de doutoramento, The Johns Hopkins University, 1987.

GARNER, L. Justiça Administrativa no Brasil Império (1842-1889), XX International Congress, Latin American Studies Association. Guadalajara, México, 1997.

GONÇALVES, M.A., Narrativa Biográfica e Escrita da História: Octávio Tarquínio de Sousa e seu Tempo. in: Revista de História 150 (1 $\left.1^{\circ} 2004\right)$

GOULD, E., The Legal Geography of the British Empire, circa 1772. The William and Mary Quartely, Williamsburg, v. 60 n.3.

GORDLEY, J., Myths of The French Civil Code in: American Journal of Comparative Law, v. XLII, 3, p.p. 459-505.

GUEDES, T.D., O Concerto da Neutralidade. Análise da Formação Teórica do Poder Neutro Na Obra de Benjamin Constant. 1997. Dissertação (Mestrado em Ciência Política (Ciência Política e Sociologia)) - Sociedade Brasileira de Instrução SBI/IUPERJ, Coordenação de Aperfeiçoamento de Pessoal de Nível Superior. Orientador: Marcelo Gantus Jasmin

GRAHAM, R., Construindo uma Nação no Brasil do Século XIX: Visões Novas e Antigas Sobre Classe, Cultura e Estado in: Diálogos, DHI/UEM, v. 5, n. 1. p. 1147, 2001.

GRAHAM, R., O Brasil de Meados do Século XIX à Guerra do Paraguai in: Bethell, L. (org.), História da América Latina, Da Independência a 1870. São Paulo, EDUSP e Imprensa Oficial, 2001.

GRINBERG, K., O Fiador dos Brasileiros. Cidadania, Escravidão e Direito Civil no Tempo de Antônio Pereira Rebouças. Rio de Janeiro, Civilização Brasileira, 2002.

GRINBERG, K., Escravidão e Liberdade na fronteira entre o Império do Brasil e a República do Uruguai: notas de pesquisa. Cadernos do CHDD (FUNAG), v. 5, p.p. 91-114, 2007.

HAMILTON, A. ; MADISON, J.; JAY, J. O Federalista. Brasília, UnB. Ano?

HOLANDA, S.B. H. História Geral da Civilização Brasileira Volume 7: Do Império à República. Bertrand Brasil, Rio de Janeiro, 1997.

HOBSBAWN, E.J., e RANGER, T. (org.), A Invenção das Tradições. São Paulo, Paz e Terra, 2002.

HORBACH, Carlos Bastide ; TELES FILHO, Eliardo França . O informante: A função administrativa no ensaio do Visconde do Uruguai. Prismas: Direito, Políticas 
Públicas e Mundialização, v. 3, p. 389-403, 2006. in:

www.uniceub.br/revistamestrado/vol3-2/pdf/ELIARDO.pdf

IANNI, O. As metamorfoses do escravo. São Paulo: Difusão Européia do Livro, 1962

JASMIN. M.G., História dos Conceitos e Teoria Política e Social: Referências Preliminares in: Revista Brasileira de Ciências Sociais, n57. São Paulo, ANPOCS, fevereiro/2005.

JASMIN, M. G., Historiografia de Tocqueville como Ciência da Política, Ano de Obtenção: 1995. Doutorado em Ciência Política (Ciência Política e Sociologia). Sociedade Brasileira de Instrução - SBI/IUPERJ, SBI/IUPERJ, Brasil

JASMIN, M. G. . Argumento e referência: a recepção de Weber em Os Donos do Poder. In: IX Congresso da Sociedade Brasileira de Sociologia, 1999, Porto Alegre. Resumo dos Grupos temáticos. Porto Alegre, 1999.

JASMIN, M. G. . Moderno e modernidade na primeira edição de Os Donos do Poder (1958). In: XX Simpósio Nacional de História, 1999, Florianópolis. História: Fronteiras. XX Simpósio Nacional de História. Florianópolis : ANPUH, 1999.

JAVARI, B., Organizações e programas ministeriais: regime parlamentar no Império. Rio de Janeiro, Ministério da Justiça, 1962.

JORGE, V. R. . O Federalismo e a organização do Estado Nacional segundo Bernardo Pereira de Vasconcellos e Visconde do Uruguai. 2000. (Apresentação de Trabalho/Comunicação).

JUNIOR, José Cretela, Contencioso Administrativo in: LIMONGI FRANÇA (org.), Enciclopédia Saraiva do Direito. São Paulo, Saraiva, 1978.

LEFORT, C., As Formas da História: Ensaios de Antropologia Política. São Paulo, Editora Brasiliense, 1979.

LENHARO, A., As tropas da moderação: o abastecimento da Corte na formação política do Brasil, 1808-1842. São Paulo : Símbolo, 1979.

LEVI, G., Usos da Biografia in: FERREIRA, Marieta de Moraes \& AMADO, Janaína (orgs.), Usos e Abusos da História Oral. Rio de Janeiro, Fundação Getúlio Vargas, 1996.

LIMA, M.A., A Cidade e a Província de São Paulo às Vésperas da Revolução Liberal de 1842 . http://www.klepsidra.net/klepsidra15/rev1842.htm

LIMA,R. P., A Nefanda Pirataria de Carne Humana.: Escravizações Ilegais e Relações Políticas na Fronteira do Brasil Meridional (1851-1868). Porto Alegre, Dissertação de Mestrado apresentada ao Programa de Pós-Graduação em História da Universidade Federal do Rio Grande do Sul, 2010.

LOPES, J.R.L., As Palavras e a Lei. Direito, Ordem e Justiça na História do Pensamento Jurídico Moderno. São Paulo, Fundação Getúlio Vargas e Editora 34, 2004.

LOPES, J.R.L., Consultas da Seção de Justiça do Conselho de Estado (1842-1889), a Formação da Cultura Jurídica Brasileira. In: Almanack Braziliense $\mathrm{n}^{\circ} 5$ maio/2007.

LOPES, J.R.L.,O Oráculo de Delfos. O Conselho de Estado no Brasil-Império. São Paulo, Editora Saraiva e Fundação Getúlio Vargas.

LOPES,J.R.L, O Supremo Tribunal de Justiça no Apogeu do Império (1840-1871). in: LOPES,J.R.L (org.), O Supremo Tribunal de Justiça do Império (1828-1889). São Paulo: Editora Saraiva \& Fundação Getúlio Vargas, 2010. 
LYNCH, C.E.C., O Momento Monarquiano. O Poder Moderador e o Pensamento Político Imperial. Tese de Doutorado em Ciência Política. Rio de Janeiro, IUPERJ, $2007 .$.

MACEDO, U. O Visconde de Uruguai e o Liberalismo Doutrinário.In: CRIPPA, Adolpho (organizador), As idéias políticas no Brasil, São Paulo: Convívio, 1979, vol. 1, pg. 193-232.

MACEDO, U. B. . A liberdade no Império. São Paulo: Convívio, 1977.

MADELÉNAT, La Biographie. Paris, PUF, 1984

MÄDER, Maria Elisa Noronha de Sá. Civilização e barbárie : a representação da nação nos textos de Sarmiento e do Visconde do Uruguai [Tese da UFF] / Maria Elisa Noronha de Sá MÄDER., 2006. .235 f Orientador : Marco Antonio Villela Pamplona. Tese (doutorado) - Universidade Federal Fluminense, Departamento de História, 2006. Bibliografia : f.215-235.

MÄDER, Maria Elisa Noronha de Sá . Ordem e Civilização: a idéia de nação nos textos do Visconde do Uruguai. In: Rachel Soihet; Maria Fernanda B. Bicalho e Maria de Fátima S. Gouvêa. (Org.). Culturas Políticas: ensaios de história cultural, história política e ensino de história. $1^{\mathrm{a}}$ ed. Rio de Janeiro: Mauad, 2005, V. , p. 177-198.

MÄDER, Maria Elisa Noronha de Sá . As nações imaginadas da Argentina e do Brasil nos textos de Sarmiento e do Visconde dop Uruguai. In: Klaus-Dieter Ertler; Enrique Rodrigues-Moura. (Org.). Fronteras e identidades - Identidades e fronteiras. Frankfurt: Peter Lang, 2005, v. , p. 45-64

MAGALHÃES, Basílio de. A Circular de Theophilo Ottoni, de setembro de 1860. Revista doInstituto Histórico e Geográfico Brasileiro, Rio de Janeiro, Imprensa Nacional, 1916, tomo LXXVIII, parte II, p. 145-387.

MALHEIRO, P. A Escravidão no Brasil: Ensaio Histórico-Jurídico-Social. Petrópolis: Vozes, 1976.

MAMIGONIAN, B.G.. To be a liberated African in Brazil: labour and citizenship in the nineteenth century. Tese de Doutorado. Waterloo, Ontario, Canada, 2002.

FREITAS, M.C., Pensamento Social, Ciência e Imagens do Brasil: Tradições Revisitadas Pelos Educadores Brasileiros in: Revista Brasileira de Educação, setdez, 2000, no 15. Campinas, Associação Nacional de Pós-Graduação e Pesquisa em Educação, $2000 . \quad$ Disponível http://www.anped.org.br/rbe/rbedigital/rbde15/rbde15_05_marcos_cezar_de_freita s.pdf

MARQUESE, R.B., Governo dos Escravos e Ordem Nacional: Brasil e Estados Unidos (1820-1860) in: Jancsó, I. (org.) Brasil: Formação do Estado e da Nação. São Paulo, Hucitec, 2003.

MARSON, I., A., O Império do Progresso. São Paulo, Brasiliense, 1987.

MARSON, I.A., Movimento Praieiro: Imprensa, Ideologia e Poder Político. São Paulo, Moderna, 1980.

MARTINEZ, F., La Historiografia de Las Instituiciones Administrativas em España (siglos XIX-XX) Disponível em:

http://revista.fajardolopez.com/index.php?name=Sections\&req=viewarticle\&artid $=39 \&$ allpages $=1 \&$ theme $=$ Printer. 
MATTEUCCI, Contratualismo in: BOBBIO, N., MATTEUCCI, N., PASQUINO, G., Dicionário de Política. Brasília, Editora UnB, 1998.

MATTEUCCI, Constitucionalismo in: BOBBIO, N.,MATTEUCCI, N., PASQUINHO, G., Dicionário de Política. Brasília, Editora UnB, 1998.

MATTOS, I.R., O Tempo Saquarema. Editora Hucitec, São Paulo, 1987.

MATTOS, I.R., O Lavrador e o Construtor: O Visconde do Uruguai e a Construção do Estado Imperial in: PRADO, M.E., O Estado Como Vocação:Idéias Políticas no Brasil Oitocentista. Rio de Janeiro, Access, 1999.

MARX, K., Contribuição Para a Crítica da Economia Política. Lisboa, Estampa, 1974

MERCADANTE, Paulo. "Visconde de Uruguai, teórico da constante conservadora". In: Revista Panfleto, Rio de Janeiro, no. 6, (agosto de 1959).

MERCADANTE, Paulo. A consciência conservadora no Brasil. $3^{\text {a }}$.Edição, Rio de Janeiro: Nova Fronteira, 1980.

MILL. J.S., Sobre a liberdade. Petrópolis, Vozes, 1991.

MIGNOZZETTI, U.G., A Apropriação de Modelos Estrangeiros Pelo Pensamento Brasileiro: os Casos de Bernardo Pereira de Vasconcelos, Marquês de São Vicente e Visconde do Uruguai. São Paulo, Dissertação de Mestrado apresentada ao Programa de Pós-Graduação em Ciência Política da Universidade de São Paulo, 2009.

MIGNOZZETTI, U. G. . Pensamento, Aparelho Estatal Imperial e Influências Estrangeiras: Um estudo sobre as influências francesas no pensamento de Visconde do Uruguai. Revista Três Pontos, v. 3, p. 71, 2006.

MIGNOZZETTI, U. G. . Pensamento e Construção do Aparelho Estatal no Brasil Império. In: Pensamento e Construção do Aparelho Estatal no Brasil Império, 2006, Belo Horizonte. Anais ABCP, 2006.

MONTAGNER, M.A., Trajetórias e biografias: notas para uma análise bourdiesiana in: Sociologias, ano 9, $\mathrm{n}^{\circ} 17$, jan./jun. 2007, p.240-264.

NABUCO, Joaquim, Um Estadista do Império. São Paulo, Companhia Editora Nacional, 1936.

NABUCO, J. O Abolicionismo. São Paulo, Nova Fronteira/Publifolha, 2000.

NEEDELL, J.D., The Party of Order. The Conservatives, the State, and Slavery in the Brazilian Monarchy, 1831-1871. California, Stanford University Press, 2006.

NEQUETE, L. O Escravo na Jurisprudência Brasileira: Magistratura e Ideologia no Segundo Reinado. Porto Alegre: Tribunal de Justiça do Rio Grande do Sul, 1988.

NEVES,L.M.B.P.. As imagens de Napoleão Bonaparte na produção dos impressos e livros luso-brasileiros (1808-1846). In: Congresso Brasileiro de Ciências da Comunicação, 27., 2004. Porto Alegre. Anais... São Paulo: Intercom, 2004. Disponível em: http://reposcom.portcom.intercom.org.br/dspace/bitstream/1904/17508/1/R2040$\underline{1 . p d f}$

OLIVEIRA Jr., C.M., Entre virtudes e interesses: liberdade, cidadania e sistema representativo em Benjamin Constant e Alexis de Tocqueville. 2003. Tese (Doutorado em História Social) - Universidade de São Paulo.

OLIVEIRA, C.H.S., O Conselho de Estado e o Complexo Funcionamento do Governo Monárquico no Brasil do Século XIX. In: Almanack Braziliense nº5 maio/2007. 
OLIVEIRA, C.H.S., Da Natureza e dos Limites do Poder Moderador e a Memória do Conselheiro Zacarias de Góis e Vasconcelos in: OLIVEIRA, C.H.S. (ORG), Zacarias de Góis e Vasconcelos. São Paulo, Editora 34, 2002.

OLIVEIRA, C.H.S. Contribuição ao Estudo do Poder Moderador in: OLIVEIRA, C.H.S. BITTENCOURT, V.L.N. COSTA, V.P. Soberania e Conflito. São Paulo, Hucitec e Fapesp, 2010.

OLIVEIRA, C.H.S. O Poder Moderador no segundo reinado-mediações entre fontes e historiografia. in: Justiça e História, Vol.3, $\mathrm{n}^{\circ} 5$. Porto Alegre: Tribunal de Justiça do Rio Grande do Sul, 2003, p.p. 141-160 Disponível em: http://www.tj.rs.gov.br/institu/memorial/RevistaJH/vol3n5/05_Cecilia_Salles.pdf

PAIM, Antônio. A discussão do Poder Moderador no Segundo Império. $2^{\mathrm{a}}$. Edição revista, Rio de Janeiro: Universidade Gama Filho, 1994.

PASSERON, J.C., A Encenação e o Corpus - Biografias, Fluxos Itinerários e Trajetórias in: PASSERON, J.C., O Raciocínio Sociológico - O Espaço NãoPoperiano do Raciocínio Natural. Petrópolis, Vozes, 1995.

PARRON, T.P., A Política da Escravidão no Império do Brasil, 1826-1865.

Dissertação de Mestrado apresentada ao Programa de Pós-Graduação em História Social, FFLCH/USP. São Paulo, 2009.

PARRON, Tamis, A Nova e Curiosa Relação (1764): escravidão e Ilustração em Portugal Durante as Reformas Pombalinas in: Almanack Braziliense (Recurso Eletrônico) Volume 8. São Paulo, Instituto de Estudos Brasileiros da Universidade de São Paulo, Segundo Semestre de 2008.

PARSONS. Talcott, The Social System. Londres, Routledge \& Kegan Paul, 1970.

PINTO, Edmundo da Luz, Principais Estadistas do Segundo Reinado. Rio de Janeiro, José Olympio, 1943.

PRADO, M.E. A questão nacional, a identidade cultural e o passado colonial brasileiro. Manoel Bomfim e uma interpretação do significado das raízes. In: Revista Eidal, v. 16, $\mathrm{n}^{\circ}$.

PRADO, M.L.C., O Brasil e a Distante América do Sul in: Revista de História, no ${ }^{145}$, São Paulo, dez. 2001. Disponível em: http://www.revistasusp.sibi.usp.br/scielo.php?script=sci_arttext\&pid=S0034$83092001000200004 \& \operatorname{lng}=$ pt\&nrm=iso

POCOCK, J.G.A., O Conceito de Linguagem e o Métier D'Historien: Algumas Considerações Sobre a Política in: MICELI, S. (org.), Linguagens do Ideário Político. São Paulo, EDUSP, 2003.

RAMALHO, J.I., Elementos do processo criminal : para uso das faculdades de direito do império. São Paulo : Dous de Dezembro, 1856.

RODRIGUES, José Honório. O Conselho de Estado. Brasília, Senado Federal, 1978

RODRÍGUEZ, R.V., Paulino José Soares de Sousa - Visconde do Uruguai (18071866), Ícone do Pensamento Estratégico Brasileiro. Disponível em: http://www.defesa.ufjf.br/fts/PSS.pdf

SILVA, Inocêncio Francisco da. Dicionário bibliográfico português. Lisboa: Imprensa Nacional, 1862, vol. 6,pg. 361. $2^{\mathrm{a}}$.Edição, Lisboa: Imprensa Nacional, 1894, vol. 17, pg.150.

RODRIGUES, J. O infame comércio: propostas e experiências no final do tráfico de africanos para o Brasil (1800-1850). Campinas, UNICAMP, 2000. 
ROMERO, Silvio. O Brasil social de Euclides da Cunha. In: Realidades e ilusões no Brasil: parlamentarismo e presidencialismo e outros ensaios. Seleção e coordenação de Hildon Rocha. Petrópolis: Vozes/ Aracaju: Governo do Estado de Sergipe, 1979.

SALLES, R,. Biografia e história intelectual: sujeitos sociais, processo, totalidade e sentido. Comunicação apresentada no X Encontro Regional de História e Biografias. Rio de Janeiro, UERJ, 2002.

SALLES,R., E o vale era o escravo: Vassouras, século XIX. Senhores e escravos no coração do Império. Rio de Janeiro: Civilização Brasileira, 2008.

SCHWARZ , R., As Idéias Fora do Lugar. in: SCHWARZ , R., Ao Vencedor as Batatas. São Paulo, Editora 34 e Editora Duas Cidades, 2000.

SCOTT, Rebeca, J., A Emancipação Escrava em Cuba, A Trasição para o Trabalho Livre, 1860-1899. São Paulo, Paz e Terra, 1991.

SILVA, Mauricio Adelino da, O Visconde do Uruguai e a escravidão. Início: 2006. Trabalho de Conclusão de Curso (Graduação em história) - Pontifícia Universidade Católica do Rio de Janeiro.

SLENES, R. 'Malungo, Ngoma vem': África coberta e descoberta no Brasil.in: Revista USP nº12. São Paulo: EDUSP, 1991/1992.

SISSON, S. A. Guia dos brasileiros ilustres. Brasília: Senado Federal, 1999, vol. I, pg. 47-54.

SKINNER, Q., Meaning and Understanding in the History of Ideas. In: History and Theory, Vol.8, nº1 (1969), p.p. 3-53. Publicação da Wesleyan University.

SLEMIAN, A., Sob o império das leis: constituição e unidade nacional na formação do Brasil (1822-1834). São Paulo, Tese de Doutorado, FFLCH/USP, 2006.

SOUZA, A.B., "Biografia e escrita da história: reflexões preliminares sobre relações sociais e de poder". Revista Universidade Rural: Série Ciências Humanas. Seropédica-RJ: EDUR, v. 29, n. 1, jan-jul., 2007.

SOUZA NETO, Paulino José Soares. "O Visconde de Uruguai e a consolidação da ordem em 1842”. In: MINISTÉRIO DA EDUCAÇÃO E SAÚDE, Anuário do Museu Imperial, Petrópolis: Imprensa Nacional, 1945, pg.105-128.

SOUZA, J.A.S., Os Escravos e a Pena de Morte no Império in: Revista do Instituto Histórico e Geográfico Brasileiro, Volume 313, Outubro-Dezembro - 1976. Rio de Janeiro, Departamento de Imprensa Nacional, 1977.

SOUZA, J. A. Soares de. A vida do Visconde de Uruguai (1807-1866). São Paulo: Companhia Editora Nacional, 1944.

SOUZA, José Antonio Soares de, Prefácio,in: RODRIGUES, J. H., (ORG.) Atas do Conselho de Estado Pleno, Terceiro Conselho de Estado (1850-1857). Brasília, Senado Federal, 1978.

SOUZA, J.A.S., A Queda de Rosas in: Revista do Instituto Histórico e Geográfico Brasileiro, Volume 264 Julho-Setembro, 1964. Rio de Janeiro, Imprensa Nacional, 1965.

SOUZA, Francisco Belisário Soares de., O Sistema Eleitoral no Império. Brasília, Senado Federal, 1979.

SOUZA, Braz Florentino Henriques de, Do poder Moderador: ensaio de Direito Constitucional. Brasília, Senado Federal, 1978. 
SOUZA, O.T., História dos Fundadores do Império do Brasil .Rio de Janeiro, José Olímpio, 1957.

SUSEKIND, Rita Lagoeiro, Civilização e Ordem: o projeto político do Visconde do Uruguai. 2005. Trabalho de Conclusão de Curso. (Graduação em história) Pontifícia Universidade Católica do Rio de Janeiro. Orientador: Maria Elisa Noronha de Sá Mäder.

TORRES, João Camillo de Oliveira. Os construtores do Império. São Paulo: Companhia Editora Nacional, 1968.

TORRES, João Camillo de Oliveira. A democracia coroada: teoria política do Império do Brasil. Rio de Janeiro, José Olympio, 1957.

VAINFAS, R. (org.), Dicionário do Brasil Imperial.Rio de Janeiro, Objetiva, 2002. VILELA. A., Distribuição Regional das Receitas e Despesas do Governo Imperial. Disponível em: http://www.anpec.org.br/encontro2004/artigos/A04A017.pdf

VIANNA, H. Vultos do Império. São Paulo, Ed. Nacional, 1968.

WEBER, Max., Economia y Sociedad. México, Fondo de Cultura Económica, 1969.

WEHLING, A., Ruptura e Continuidade no Estado Brasileiro, 1750-1850. Disponível $\mathrm{em}$ : http://hc.rediris.es/05/articulos/doc/09.doc 